\title{
A SAÚDE PÚBLICA E A PSICANÁLISE: \\ A PRODUÇÃO DO CONHECIMENTO NO BRASIL ACERCA DA AIDS
}

\section{DIVA MARIA FALEIROS CAMARGO MORENO}

Dissertação de Mestrado apresentada ao Departamento de Saúde Materno Infantil da Faculdade de Saúde Pública da Universidade de São Paulo para obtenção do Grau de Mestre.

Área de Concentração: Saúde Materno Infantil

Orientador: PROF. DR. ALBERTO OLAVO ADVÍNCULA REIS

São Paulo

2001 
Autorizo, exclusivamente, para fins acadêmicos e científicos, a reprodução total ou parcial desta dissertação, por processos fotocopiadores.

São Paulo, agosto de 2001. 
À memória de meu pai, o maior incentivador dos meus estudos. 


\section{AGRADECIMENTOS}

Foram muitas as pessoas que colaboraram para que esta dissertação fosse realizada, sendo difícil expressar toda a gratidão que elas merecem. Esperando poder retribuir um dia, agradeço...

À Dona Zenaide, minha mãe, que mesmo sem entender para que tanto estudo, aceitou e compreendeu as minhas ausências nos encontros de família.

Ao Moreno, meu marido e companheiro de tantos anos, por acompanhar e suportar, sempre calado, as horas e horas diante dos livros e da tela do computador.

Às minhas queridas filhas Paula, Ana Carolina e Renata, que estiveram o tempo todo solidárias, por vezes, solícitas, admirando e se escandalizando com o tamanho das palavras, das frases e do trabalho final.

Ao meu sobrinho Rafael, meu hóspede sempre interessado nos progressos em cada etapa do trabalho.

Ao Mark, meu filho americano que em pleno verão brasileiro fez questão de opinar sobre o meu resumo em inglês.

Aos meu irmão, irmãs, cunhadas e cunhados, especialmente à minha irmã Jane, que mesmo sem entender do assunto, dispôs-se a revisar uma parte do trabalho no ano mais doloroso de sua vida e à Maria Celene, pela revisão do summary.

Aos meus sobrinhos e sobrinhas, por serem meus grandes amigos e incentivadores.

Aos colegas do COAS Lapa, por compreenderem minhas ausências e pela cobertura na escala de trabalho. O meu muito obrigada à Elvira, Rita, Diva, Eliana, Mona, Cristina, Joana, Breno, Lucila, Armanda e Conceição. À Lúcia, por me acompanhar de perto, discutindo, sugerindo e enriquecendo minhas reflexões.

Às colegas da UBS Vila Romana, sempre prestativas e amigas: Berenice, Maria Helena, Ione, Lea, Elaine, Branca, Ruth e, especialmente à Dra Albina, minha chefe, que sempre soube compreender e respeitar as minhas necessidades. 
À Vânia, amiga que sempre deu apoio nas horas difíceis, ajudando-me a vencer os impasses teóricos, e colocando seu saber e seus livros à minha disposição.

Às colegas de consultório pelo apoio e estímulo, quase que diário, em especial, à Isabella e Marcella, grandes amigas. Hiromi e Paulo por dedicarem um pouco do seu tempo a este trabalho, fazendo correções e leitura crítica.

Aos colegas da pós-graduação Betina e Clarissa, por estarem sempre comigo nos momentos complicados deste percurso e pela ajuda na vigilância dos prazos; Wilson e Luís, pelas conversas agradáveis; Esther e Dácio, pela sintonia nos trabalhos acadêmicos que fizeram comigo.

À Iara, pelos e-mails prestativos e colaboradores.

Ao Núcleo de Estudos e Pesquisas em Aids (NEPAIDS): Vera Paiva, por permitir que eu fosse aluna ouvinte do Curso de Metodologia de Pesquisa em Aids, através do qual aprendi a escrever projetos e pude conhecer pessoas a quem devo muitos conhecimentos; Jorge Beloque, pela paixão contagiante pela ética em pesquisa envolvendo seres humanos; Maria do Rosário de Oliveira Latorre e Wilza Villela, por orientarem meu primeiro projeto de pesquisa transformado em trabalho científico e Robson, por me ajudar a vasculhar os arquivos desse núcleo em busca de material de análise.

Ao Núcleo de Pesquisa "Psicanálise e Sociedade" da PUC-SP, na pessoa de seus coordenadores Raul e Miriam, por me acolherem e permitir que eu participasse das discussões sempre muito ricas e proveitosas. Aos demais membros do núcleo, Sandra, Fátima, Maurício, Tiago, Paulo, Erane e Rosana, pelo companheirismo e amizade. A Taeco, por ter lido e comentado o meu trabalho. Foi um grande apoio.

Sendo esta uma pesquisa essencialmente bibliográfica, ela não seria possível sem a ajuda do pessoal da biblioteca da Faculdade de Saúde Pública que, incansável, sempre se dispôs a me acompanhar nas incursões às bases de dados e na obtenção de material de outras universidades. A mesma disponibilidade obtive de Juliana A. Takahashi, bibliotecária do Instituto de Psicologia da USP.

Às pesquisadoras Maria Elisa Pessoa Labaki, Renate Meyer Sanches e Ana Cleide Moreira, que, mesmo sem me conhecer, enviaram-me, com presteza e 
rapidez, as referências bibliográficas de que dispunham, amplamente utilizadas neste trabalho.

Ao Prof. Dr. Nelson Coelho Junior, que se dispôs a me receber e a dialogar comigo, sugerindo leituras interessantes e dando suporte para o prosseguimento em uma etapa crítica deste estudo.

Aos funcionários do Departamento de Saúde Materno Infantil, pela acolhida carinhosa e sempre sorridente desde os primeiros tempos: Sônia, Meire, Elba, Leandro, Maria, Nilson e especialmente à Iara, que durante as festas de Natal digitou boa parte do manuscrito.

À Faculdade de Saúde Pública, representada pelos seus bons professores e funcionários educados e gentis, por possibilitar o desenvolvimento de trabalhos como este e ao CNPq, pelo apoio financeiro.

À Prof. Dra. Maria Inês Assumpção Fernandes, do Departamento de Psicologia Social e do Trabalho da USP, pela acolhida em sua disciplina, pela atenção e confiança e por ter aceitado participar da banca examinadora desta dissertação desde o Exame de Qualificação.

Ao Prof. Dr. José Ricardo Carvalho Mesquita Ayres, pelas muitas contribuições dadas no Exame de Qualificação, na Pré-banca, e por se dispor a me ouvir sempre que foi solicitado.

Ao Prof. Dr. Raul Albino Pacheco Filho, pela confiança em mim depositada, por acreditar neste trabalho e por aceitar o desafio de participar, pela primeira vez, de uma banca examinadora na Faculdade de Saúde Pública.

Ao Prof. Dr. Alberto Olavo Advíncula Reis, meu orientador, por aceitar a minha proposta de trabalho e pela complacência frente às minhas insistências e intolerâncias. 


\section{ÍNDICE}

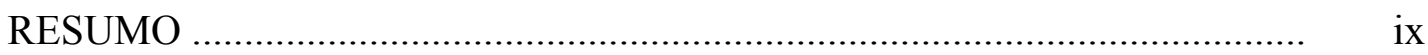

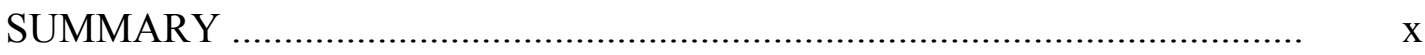

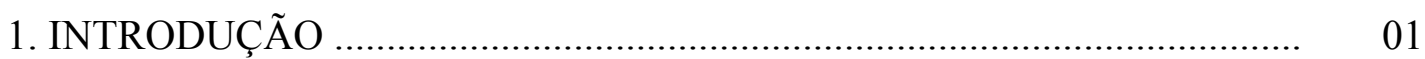

1.1. O panorama mundial - Do início aos dias atuais ..................................... 05

1.2. Um pouco do campo da saúde pública... ................................................. 11

1.3. A respeito da psicanálise... ............................................................. 14

1.3.1. A psicanálise na medicina: alguns percursos .............................. 15

1.3.1.1. Franz Alexander e a medicina psicossomática .................. 16

1.3.1.2. As concepções de Pierre Marty........................................... $\quad 25$

1.3.2. Interfaces ................................................................................. 33

1.4. A proposta de revisão bibliográfica ………............................................... 36



2.1. Objetivo Geral ............................................................................. 40

2.2. Objetivos Específicos .................................................................... 40

3. METODOLOGIA …........................................................................... 41

3.1. Interpretação, compreensão e explicação ................................................. 41

3.2. Procedimentos de coleta e organização dos dados ................................... 51

4. CONSIDERAÇÕES ÉTICAS .................................................................. 58

5. RESULTADOS E DISCUSSÃO _............................................................... 59

5.1. A delimitação do material .................................................................. 59

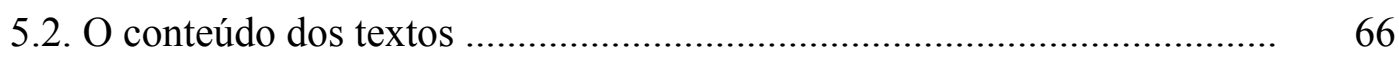

5.2.1. Organização dos serviços de saúde pública para o atendimento do paciente com HIV/AIDS ......................................................... 68

5.2.2. O impacto do diagnóstico ........................................................ 75

5.2.3. O atendimento psicanalítico ....................................................... 82

5.2.4. Reflexões teóricas frente à epidemia ........................................... 99

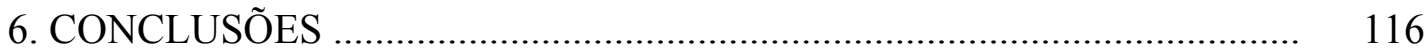

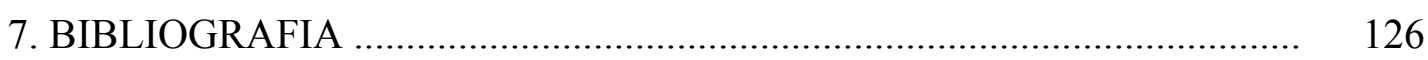

8. REFERÊNCIAS BIBLIOGRÁFICAS .................................................... 131 ANEXOS 
Anexo 1 - Relação de periódicos envolvidos na pesquisa "5 anos de bibliografia sobre AIDS/SIDA"

Anexo 2 - Textos relacionados a aspectos psicológicos e psicopatológicos referidos em "5 anos de bibliografia sobre AIDS/SIDA"

Anexo 3 - Bases de dados envolvidas na pesquisa "Efeitos da educação sexual dos jovens".

Anexo 4 - Relação de trabalhos a que não se teve acesso

Anexo 5 - Modelo de carta enviada a profissionais e instituições

Anexo 6 - Relação de textos indicados na bibliografia dos trabalhos analisados

Anexo 7 - Modelo de ficha técnica A-7

Anexo 8 - Relação de textos excluídos A-8

Anexo 9 - Fichas técnicas dos 50 textos analisados 
Moreno DMFC. A saúde pública e a psicanálise: a produção do conhecimento no Brasil acerca da aids. São Paulo; 2001. [Dissertação de Mestrado - Faculdade de Saúde Pública da USP].

\section{RESUMO}

O presente estudo tem por objetivo verificar o estado do conhecimento envolvendo os temas psicanálise e aids no âmbito da produção literária brasileira referente à saúde pública e à psicanálise.

Trata-se de uma pesquisa de atualização que faz a revisão bibliográfica dos textos publicados desde o início da epidemia de aids até o ano 2000. Efetuou-se uma busca sistematizada abrangendo artigos de periódicos indexados nas Bases de Dados: MEDLINE, PSICLIT, SOCIALFILE e LILACS, dissertações, teses, livros, capítulos de livros e comunicações em eventos.

Foram analisados 50 documentos organizados em seqüência cronológica em relação ao ano de publicação. A técnica de análise de conteúdo foi utilizada mediante a construção de categorias definidas a priori, a partir dos objetivos da pesquisa, do conhecimento do campo psicanalítico e do perfil da epidemia de aids.

Com base na sistematização desse conhecimento construído no Brasil disponibiliza-se recursos teórico-práticos para implementar novos programas de prevenção que contemplem as formas pelas quais o ser humano lida com os seus desejos e proibições. O inconsciente, produtor da irracionalidade do homem, tornouse menos desconhecido, bem como os mecanismos que impedem que as regras de proteção à saúde sejam colocadas em prática para evitar a infecção pelo vírus HIV. A dinâmica do funcionamento psíquico em torno da questão da aids foi enfocada, bem como as formas como o organismo adoece a partir desse funcionamento.

O estado do conhecimento atingido pelos trabalhos apresentados pode ser utilizado em outros estudos, com impacto sobre os sujeitos tanto no plano individual como no coletivo.

Descritores: Saúde Pública. Psicanálise e Aids. Revisão de Literatura. 
Moreno DMFC. A saúde pública e a psicanálise: a produção do conhecimento no

Brasil acerca da aids. [Public health and Psychoanalysis: knowledge construction concerning AIDS in Brazil]. São Paulo; 2001. [Dissertação de Mestrado - Faculdade de Saúde Pública da USP].

\section{SUMMARY}

The purpose of this study is to verify the state of knowledge involving the themes psychoanalysis and AIDS within the Brazilian literature regarding public health and psychoanalysis.

It is an updating research making bibliographical revision on texts published from the beginning of the epidemic of AIDS to the year 2000. A systematic search was made including newspapers articles indexed in the following data base: MEDLINE, PSICLIT, SOCIALFILE and LILACS, dissertations, theses, books, chapters of books, and communications in events.

Fifty documents organized in a chronological sequence in relation to the year of publication have been reviewed. The technique used to analyze the contents was based on categories a priori defined, based on the objectives of the research, on the psychoanalytical field knowledge, and on the AIDS epidemic profile.

Based on this systematic knowledge built in Brazil, one can utilize theoreticalpractical resources to implement new prevention programs which take into consideration the forms with which human beings deal with its desires and prohibitions. The unconscious, which produces human irrationality, has become less unknown, as well as the mechanisms which prevent the rules for health protection from being placed into practice to avoid HIV contamination. The dynamics of the psychic function surrounding the AIDS issue was focused, as well as the means through which the body falls ill due to such psychic function.

The level of knowledge reached by the presented research papers can be used in other studies, with impact on subjects on an individual plan as well as on a collective basis.

Descriptors: Public Health. Psychoanalysis and AIDS. Review of Literature. 
Autorizo, exclusivamente, para fins acadêmicos e científicos, a reprodução total ou parcial desta dissertação, por processos fotocopiadores.

São Paulo, agosto de 2001. 


\section{INTRODUÇÃO}

O presente estudo começou a ser pensado a partir da experiência de trabalho em Educação em Saúde Pública junto à população da periferia da cidade de São Paulo desde o início dos anos 90. A tarefa consistia em desenvolver um trabalho informativo, com enfoque individual ou coletivo em sua execução, visando a promoção da saúde em todos os programas: saúde da criança, saúde da mulher, saúde do adulto, saúde bucal e saúde mental, tanto no ambiente da Unidade Básica de Saúde da Rede Municipal quanto no ambiente escolar e comunitário.

As demandas eram ora programáticas, ora emergenciais, tais como: surtos de doenças infecto-contagiosas, conseqüências de enchentes, solicitações das escolas para abordar determinados assuntos, etc. Dentre esses últimos, começava a surgir, cada vez mais freqüentemente, a necessidade de abordar o tema da aids ${ }^{*}$, uma vez que os profissionais já diagnosticavam casos dessa doença no serviço e as escolas recebiam filhos de portadores do HIV sintomáticos ou assintomáticos. Desnecessário é salientar a dificuldade de lidar com o assunto tão carregado de preconceito e incapacidade, ambos ligados à falta de informação e à cultura atrelada à noção de grupos de risco do início da epidemia (noção que será explicitada e contextualizada mais adiante). $\mathrm{O}$ fato é que as demandas relacionadas à aids iam se avolumando e se transformando numa prioridade de atenção que elevou este problema de saúde ao status de "programa".

Note-se como tudo isso se procedeu em nosso país. O Brasil adotou - a exemplo da Organização Mundial da Saúde (OMS) — a classificação do HIV/AIDS como doença sexualmente transmissível. O Ministério da Saúde estabeleceu, por meio da Portaria 236, em 1985, as diretrizes para o Programa de Controle da

\footnotetext{
* O presente estudo adotará a grafia da palavra "aids", baseando-se nesta informação: “Há dois anos, uma reunião da Comissão Nacional de Aids (órgão assessor do Ministério da Saúde para assuntos de Aids e DST) tomou a seguinte deliberação:

- A palavra aids será considerada como substantivo comum, apesar de ser originária de uma sigla estrangeira. Dessa forma, a sua grafia será sempre em caixa baixa, quando se tratar da epidemia, e a exemplo de outros agravos como tuberculose, câncer, etc.

- Terá caixa baixa e alta quando for nome de um setor, título etc. Por exemplo: Coordenação Nacional de DST e Aids.
} 
Síndrome da Imunodeficiência Adquirida (SIDA/AIDS), e atribuiu uma estrutura organizativa para sua gestão nacional. "Em 1987, foi criada a Comissão Nacional de Aids, integrada por representantes da comunidade científica e da sociedade civil organizada. Foi, no entanto, somente a partir de 1988, que se constituiu e se consolidou o Programa Nacional, com a inclusão das DST” (MINISTÉRIO DA SAÚDE 1998, p.32). Após a promulgação da Constituição Federal Brasileira (em 1988), várias leis foram expedidas para regulamentar o funcionamento dos diversos setores, dentre eles, o setor saúde. A partir do Decreto 99.244 de 10/05/90, a Coordenação Nacional de DST e Aids passou a fazer parte do Departamento Nacional de Programas de Saúde, congregando esforços diversos no sentido da prevenção e controle da epidemia no país.

Devido à concentração de casos no Estado de São Paulo, a Secretaria de Estado da Saúde lançou o projeto de criação de seu programa em 1983 — pioneiro no Brasil. Tendo em vista “... o alto índice de letalidade da doença; a necessidade de promover um sistema adequado de acompanhamento e controle da evolução da doença no Estado; as necessidades de se promover um sistema adequado de atenção médico-hospitalar aos pacientes portadores da doença..." (MINISTÉRIO DA SAÚDE 1995, p.48), a Comissão Interinstitucional de Saúde do Estado de São Paulo constituiu, em 1986, um grupo de trabalho em caráter permanente, composto de profissionais especializados da comunidade científica e da rede básica de saúde, que passou a se reunir sistematicamente para tratar do problema, já alarmante. A partir daí, as resoluções foram se sucedendo no sentido de cuidar e tentar dar conta das demandas da população, monitorando a epidemia através dos indicadores epidemiológicos da doença.

Em 1988, foi criado o Centro de Referência e Treinamento em Aids (CRT-A), visando o atendimento multidisciplinar dos doentes e a atuação como capacitador e gerador de normas técnicas para multiplicar as informações para prevenção e controle, e incentivar a implantação de serviços de atendimento na rede pública em níveis regionais e descentralizados.

O CRT-A incorporou, em 1993, o Programa de Doenças Sexualmente

Entretanto, quando a palavra estiver no meio de outras siglas, e estas mesmas siglas forem grafadas todas em caixa alta, a palavra aids seguirá a mesma regra. Por exemplo: CN-DST/AIDS (Coordenação Nacional de DST e Aids)" (GUERRIERO 2001, p. 10, nota de rodapé). 
Transmissíveis (DST) e, em 1995, unificou-se com a Coordenação do Programa Estadual de Controle das DST/Aids, delimitando o papel estratégico da instituição como referência técnica e como sede do Programa Estadual de DST/Aids (PEDST/AIDS). Hoje esse programa atua de forma coordenada com outros setores governamentais e em integração com organizações não governamentais (ONG), permitindo “... prover atendimento, criar e validar procedimentos preventivos e modelos de assistência, (...) realizar pesquisas clínicas..." (COORDINATION OF THE STATE PROGRAM OF STD/AIDS, “sd”, p.4).

A Secretaria Municipal da Saúde da Prefeitura Municipal de São Paulo criou, em 1987, o Programa DST/Aids e implantou, inicialmente, um Centro de Orientação e Apoio Sorológico (COAS) na região central da cidade, que é responsável pelo atendimento da população na prevenção e também pelo treinamento de profissionais para atuar nesta área. Após 1995, a Secretaria da Saúde inaugurou novos serviços de prevenção e atendimento, totalizando, no momento, 12 Centros de Referência (Ambulatórios), 5 Atendimentos Domiciliares, 7 Hospitais-Dia, 5 COAS (Centro de Orientação e Apoio Sorológico) e o serviço de Disque-Aids. Essa diversidade de serviços visa a cobertura da assistência à saúde nos diferentes níveis de atenção (primário, secundário e terciário).

Está dado, assim, o panorama da organização dos programas de aids nos três níveis de governo, federal, estadual e municipal, no Brasil e na região mais atingida pela doença no país e dos serviços de cuidado a este problema de saúde pública na cidade de São Paulo.

Retornando ao início dos anos 90 e ao serviço de saúde pública, os treinamentos aos profisssionais começaram a ser oferecidos e as informações foram se disseminando a partir das diretrizes programáticas. Os profissionais que se interessavam foram se especializando e tornando-se multiplicadores de informação para a prevenção da doença, seja junto aos seus colegas de trabalho, seja junto à população.

A partir da inserção neste contexto de trabalho como profissional de saúde no front da prevenção, surgiu o interesse em refletir sobre a epidemia e desenvolver uma pesquisa como a que ora se propõe.

No próximo tópico será feito um breve relato a respeito da epidemia: como foi 
se constituindo desde os primeiros casos notificados no mundo e no Brasil, seu padrão de infecção e distribuição, os dados epidemiológicos recentes para o Brasil, as respostas da comunidade científica, os vários conceitos construídos e desenvolvidos para tentar explicá-la e controlá-la e, finalmente, a inserção da saúde pública e da psicanálise nesse contexto.

Foram incluídos dois capítulos que contam um pouco da história da aproximação da psicanálise à medicina, e introduzem algumas concepções sobre a abordagem psicossomática às doenças. Algumas articulações com a saúde pública e com a questão da aids são consideradas.

Na seqüência, são descritos os objetivos e a metodologia utilizada, havendo a incorporação do diálogo com pensadores que se preocuparam com a interpretação e compreensão nas ciências humanas. Essa inclusão visa fornecer subsídios para a leitura de textos.

Por fim, são apresentados e discutidos os resultados obtidos. As conclusões contemplam os principais aspectos inferidos a partir do material analisado e sugerem novas possibilidades de trabalho futuro. 


\subsection{O panorama mundial - Do início aos dias atuais}

Segundo BUCHALLA (1995), a aids fez com que as doenças infecciosas fossem recolocadas na agenda de todos os países do mundo, inclusive daqueles onde havia controle das mesmas, os ditos países desenvolvidos. A autora descreve a diversidade do padrão de infecção de um país para outro, de acordo com MANN e col. (1992), citados por ela em seu artigo (BUCHALLA 1995). No início da epidemia, na Europa Ocidental, nos Estados Unidos da América, na Austrália e em algumas regiões da América Latina, prevalecia o contato homossexual e o uso de drogas injetáveis como forma de transmissão (Padrão I). Nos países da África Subsaariana e do Caribe, a forma de transmissão se dava por contato heterossexual e por má esterilização de agulhas e seringas em procedimentos médicos (Padrão II). Finalmente, onde o vírus se introduziu durante os anos 80 - no Leste Europeu, Oriente Médio, Norte da África e países da Ásia — estabeleceu-se o padrão III de infecção, prevalecendo a infecção por práticas de prostituição e pelo uso de drogas injetáveis.

De acordo com a COORDENAÇÃO NACIONAL DE DST/AIDS (1998), no Brasil, a epidemia teve três fases de evolução. Na fase inicial, a via de transmissão prevalente era entre homens que fazem sexo com homens (HSH), principalmente com escolaridade alta. Na segunda fase, houve aumento de casos com transmissão por uso de drogas injetáveis, com diminuição do grupo etário e aumento de casos entre pessoas com prática sexual heterossexual. Na fase atual, acentua-se a tendência da disseminação do HIV e da aids entre heterossexuais, dentre eles as mulheres. O vírus já se introduz no interior do país (começando a atingir cidades menores) e há aumento do número de casos com nível de escolaridade mais baixo, sendo esse utilizado como um indicador da pauperização da epidemia. Essa informação se confirma através da análise feita por DHALIA, BARREIRA e CASTILHO (2000a) no último boletim do Ministério da Saúde.

Em termos de número de casos notificados, o Brasil apresenta 190940 casos até 03/06/00, dos quais 91319 estão no Estado de São Paulo. No Município de São Paulo ocorreram 41072 casos, contribuindo com 21,5\% das notificações do Brasil para o mesmo período Em números absolutos, o Município é o primeiro do Brasil, 
sendo que o Rio de Janeiro é o segundo, com um total de 18810 casos $(9,9 \%$ de todos os casos do país) e Porto Alegre é o terceiro, com 6817 casos (3,6\% do total de casos do Brasil). Em relação aos outros municípios brasileiros, São Paulo é o décimo nono em incidência de casos, com o índice de 362,3/100000 habitantes. O município com maior coeficiente de incidência é Itajaí, com 1010,0/100 000 habitantes, seguido de Balneário de Camboriú (com 947,2/100000 habitantes) e São José do Rio Preto (com 797,1/100000 habitantes), de acordo com a COORDENAÇÃO NACIONAL DE DST/AIDS (2000b) *

$\mathrm{Na}$ mesma referência, observa-se que a grande maioria $(64,4 \%)$ dos casos notificados de 1980 a 2000 encontra-se na faixa etária de 20 a 49 anos. Trata-se de uma população economicamente ativa, cujo afastamento do mercado de trabalho decorrente dos agravos da aids traz um custo social e econômico elevado. Além disso, sendo uma faixa etária em idade reprodutiva e, sendo a aids uma doença letal, cresce o número de órfãos (estimado em 29929 em todo o Brasil) ${ }^{*}$ e também o número de crianças infectadas pela transmissão vertical (de mãe para filho).

Em São Paulo, na faixa etária de 20 a 49 anos, a quarta causa de mortalidade em 1996 é a aids. No entanto, os últimos dados do PROAIM (Programa de Aprimoramento das Informações de Mortalidade no Município de São Paulo) mostram que os óbitos causados pela aids diminuíram 53,6\% em 1999, refletindo a eficácia do uso da medicação antiretroviral. No Município de São Paulo, de 1993 a 1996, a aids também foi a primeira causa de óbito entre mulheres de 15 a 49 anos (PROGRAMA MUNICIPAL DE DST/AIDS 1997b, p.15). Esse dado torna-se mais alarmante quando se analisa que a velocidade de crescimento da epidemia é maior entre as mulheres do que entre os homens, transformando a razão de masculinidade dos casos de aids de 38/1 em 1986 para 3/1 em 1996 em São Paulo (PROGRAMA MUNICIPAL DE DST/AIDS 1997a, p.4). Além disso, aumentando o número de mulheres infectadas, aumenta a chance de ocorrer a transmissão vertical, e, conseqüentemente, a população infantil infectada.

Os números apresentados particularizam a epidemia em nosso território. No restante do mundo, a distribuição e evolução, embora possa ser diferente, reflete a relevância do problema. Isso pode ser constatado pelo “... número crescente de

\footnotetext{
* Dados preliminares até a semana 22/00, terminada em 03/05/00 (Dados sujeitos à revisão).
} 
pesquisas [que] fez com que a resposta da comunidade científica à aids fosse uma das mais rápidas da história da ciência. Em dez anos, os conhecimentos sobre o agente e a doença avançaram muito...” (BUCHALLA 1995, p.333). Não se conseguiu, contudo, encontrar a cura para a aids até o presente momento.

Apesar da divulgação que passou a existir sobre as formas de infecção e as formas de prevenção do HIV, a epidemia continuou a avançar no mundo de forma bastante diversificada, de acordo com as condições sócio-econômicas dos países e suas regiões, e dos investimentos em informação e saúde, dentre outros fatores. Ela se transformou em um "mosaico de múltiplas epidemias" (COHN 1997, p.45) adquirindo um caráter mais particularizado.

Os questionamentos a respeito das razões que estão associadas à dificuldade de controle da epidemia e ao aumento do número de casos não tardaram a surgir, e percebeu-se a necessidade de se somar saberes e de estabelecer parcerias de campos de estudos. Nesse sentido, é interessante observar a análise feita por AYRES e col. (1997) que recupera as respostas tecno-científicas (no dizer dos próprios autores) desde o início da epidemia até os dias atuais, localizando-as em três períodos, de acordo com suas características:

\section{a) Período da descoberta, de 1981 a 1984:}

O instrumental epidemiológico foi utilizado frente à nova enfermidade que surgia na França e nos EUA e, através do mesmo, se chegou aos "fatores de risco" associados a ela (destaque dos autores). A conseqüência desse tipo de abordagem da doença foi o estabelecimento da conexão entre as possíveis características implicadas na produção do agravo em estudo e a transmutação no conceito de grupo de risco. $\mathrm{O}$ nome dessa categoria de análise da epidemia (o grupo de risco) tornou-se de domínio público e as políticas de saúde da época focalizaram tanto este aspecto que, inevitavelmente, as iniciativas de prevenção giraram em torno dele. Nasceram, nesse momento, ações, sentimentos e atitudes ligados ao estigma, ao preconceito, ao individualismo e ao insucesso (AYRES e col. 1997, p.22), mantidos até os dias atuais e que, hoje, constituem entraves ao próprio enfrentamento da pandemia, mas perfeitamente adaptados às segregações sociais (a serviço de sua manutenção). 


\section{b) De 1985 - 1988:}

A comunidade científica já admite a pandemia, não mais restringindo a doença aos chamados grupos de risco — os quatro Hs: haitianos, hemofílicos, usuários de droga (com h de heroína) e homossexuais. Essa denominação começa a ser identificada como emblemática do preconceito e da carência de respostas mais eficazes ao controle da doença. Sua substituta, a expressão comportamento de risco, passa a ser adotada na tentativa de instrumentalizar o indivíduo para se apropriar da própria prevenção e de desestigmatizar os segmentos da população mais atingidos pela epidemia até então. Nesse contexto, a noção de "empowerment" (BATHIVALA 1994; HEYZER 1996, citados por AYRES e col., 1997) - grifo deles e tradução aproximada para "empoderamento" — é introduzida numa “...perspectiva crítica positiva para os modelos cognitivistas que embasam os conceitos e práticas ligados ao comportamento de risco" (p.23). As intervenções educativas que utilizam esses modelos priorizam a apropriação das informações ao nível da consciência no controle do comportamento. Visam, com uma noção como a que está sendo tratada, o fortalecimento da autonomia do indivíduo.

Mas o que vem a ser essa noção, a de empowerment? Faz-se aqui um pequeno parêntese, na tentativa de elucidação da mesma.

Em um trabalho brasileiro, o conceito de empowerment pode ser entendido como o "poder de uso do preservativo" e aponta para o risco de deslocar a mulher de uma posição de submissão ao poder de decisão do homem quanto ao uso do preservativo, para outra na qual deteria ela mesma esse poder. Neste sentido, pode contribuir para a reprodução, tanto das hierarquias de gênero, como de concepções dominantes de sexualidade na sociedade de consumo (GIFFIN 1998).

O empowerment pode ser entendido também como o senso de poder do uso ou não do conhecimento adquirido, assumindo-se os riscos e benefícios associados a ele (HARRIS e KAWNAGH 1995).

Um outro trabalho enfocando esse assunto mostra que o termo vem sendo discutido e empregado na área da saúde pública, incluído no discurso da prevenção primária do HIV/AIDS, apesar de não haver intervenções baseadas na teoria, o que reflete uma falta de consenso a respeito do significado do empowerment, de efetuar 
sua medição e das estratégias de intervenções que ele implica (BEEKER e col. 1998). Para esses autores, a conclusão é que, para sua adoção, há que se requerer mais teorias e desenvolvimentos (os autores acusam a falta de ambos no momento atual).

Entretanto, apesar da ressalva acima, verifica-se que o termo empowerment vem sendo utilizado correntemente, principalmente no que se refere aos programas de prevenção realizados com mulheres, uma vez que as mesmas vêm se igualando aos homens em número de casos novos de aids. Suspeita-se que a causa disso seja a falta de empoderamento das mulheres, pela posição de dominação masculina em relação às mesmas.

Neste sentido, há a proposta de intervenção junto a homens e mulheres com escolha sexual heterossexual (FIGUEIREDO 1998) que, apesar de não se referir diretamente ao empowerment, adota a estratégia de redução de danos — a exemplo desse tipo de abordagem com usuários de drogas - estabelecendo uma hierarquia das práticas sexuais de maior para menor risco, com o objetivo de promover práticas sexuais mais seguras e possíveis, aumentando assim o poder de prevenção da aids.

Pode-se supor que parece haver certa identificação do sujeito que recebe a orientação com o empowerment, o que confirma o êxito e o aumento da aplicação desse conceito na atualidade, ou seja: reforça-se a autonomia do indivíduo dando-lhe um certo poder sobre o seu comportamento, contando com que isso reduza suas práticas de risco para o HIV/AIDS.

Fechando o parêntese e retornando ao período tratado, de 1985 a 1988 , e ao texto de AYRES e col. (1997), as estratégias dos programas de prevenção com base comportamental mostram-se limitadas. Apesar das pesquisas e desenvolvimentos teórico-práticos, a pandemia segue seu curso inexorável. Agora avança para as classes sociais menos favorecidas, marginalizadas e para a faixa etária mais jovem.

\section{c) De 1989 aos dias atuais:}

Há um grande avanço tecnológico marcado, principalmente, pela contagem $d a$ carga viral (em nível diagnóstico) e pelo coquetel, ou drogas em associação (em nível terapêutico). O conceito nascente e promissor é o de vulnerabilidade, essencial 
para se compreender a história da infecção do HIV/AIDS e para predizer o rumo da pandemia (MANN e col. 1996). No nível biológico todos são vulneráveis à infecção pelo HIV. Ainda não foi descoberta a resistência inata ao HIV, caso ela exista. Segundo os autores, o vírus requer condições específicas para que a transmissão ocorra. Quando afirma isso, MANN está se referindo a comportamentos, nos quais há que se envolver dois ou mais participantes para essa transmissão.

Neste sentido, a necessidade de desenvolver abordagens mais sensíveis à grande diversidade de propriedades incorporadas ao fenômeno saúde-doença, vem ao encontro da noção de vulnerabilidade. Essa noção, que traduz os conflitos do ambiente social, as deficiências de informação e educação, os problemas de acesso e de qualidade da oferta dos serviços sociais e de saúde, define três planos interdependentes de determinação da maior ou menor fragilidade de indivíduos e coletividades à infecção e adoecimento pelo HIV: individual, social e programático (MANN e col. 1992). Ao analisar essas três dimensões do comportamento para a prevenção do HIV, MANN chega à conclusão que o empowerment é a antítese da vulnerabilidade.

Longe da pretensão de tratar do conceito vulnerabilidade em toda sua extensão, sua citação aqui cumpre a função de designá-lo como um referencial de análise da epidemia de HIV/AIDS em um aspecto mais amplo e abrangente e de levar em conta “... outros modos de lidar com o próprio instrumental epidemiológico na construção do conhecimento..." (AYRES e col. 1997, p.30). Segundo eles, este conceito convida a se sair das fronteiras da epidemiologia no combate à epidemia e permite a revalorização ou co-valorização de outros saberes de “... qualquer campo de conhecimento desde que tenha algo a dizer sobre a experiência populacional do adoecimento" (p.33). Os autores estão se referindo às ciências humanas e aos saberes de natureza sintético-interpretativa, como a hermenêutica. Aliam-se, assim, os esforços numa verdadeira coalizão - empresta-se o termo do grupo que criou o conceito de vulnerabilidade, já citado — de forças, dentre as quais se propõe incluir a psicanálise.

Mas, como inseri-la para tratar de um problema de saúde pública? Como agir metodologicamente? Como se estabelecer a interdisciplinaridade? Mais à frente estas questões serão detalhadas. 


\subsection{Um pouco do campo da saúde pública...}

ALVARENGA (1994) considera que o campo da saúde pública caracteriza-se pela interdisciplinaridade, por não transitar exclusivamente em um único campo, seja das ciências naturais, seja das ciências humanas. Além disso, a natureza do objeto da saúde pública possui dimensões biológica, social e psicológica, o mesmo ocorrendo com os processos saúde-doença coletivos.

Para a autora, “... embora [a saúde pública] satisfaça a condição ontológica para caracterizar-se como uma disciplina, uma vez que possui nos processos saúdedoença-morte coletivos, um objeto concreto, na sua diversidade de problemas, persiste o fato de não possuir um aparato conceitual autônomo, isto é, um sistema teórico gerador de explicações dos vários problemas que o seu objeto comporta" (ALVARENGA 1994, p.35).

Diante desses problemas, a proposta consiste em lançar mão de ferramentas de trabalho que dêem conta dos mesmos. Para tanto, ALVARENGA sugere que se adote ou se crie novos esquemas teórico-metodológicos, dentre os quais a abordagem de outras áreas do conhecimento (outras disciplinas) que concorram nesse trabalho.

Ao longo da história da saúde pública, a principal preocupação foi a determinação da doença e as metodologias foram sendo aplicadas com essa preocupação, adotando explicações unicausais ou multicausais. Construíram-se esses modelos de explicação sempre a partir do que era visível: os sinais e sintomas, a doença/morte, a contagem dos casos (indivíduos doentes/mortos), as epidemias. Para que o campo se constituísse, partiu-se desse "visível" para se chegar às raízes determinantes (encobertas): as más condições de vida, as desigualdades sociais, a insalubridade, sem desconsiderar os agentes etiológicos biológicos. Os subterrâneos da vida em sociedade e das condições de saúde-doença tiveram que vir à tona, para que se pudesse compreender esse processo. O sujeito coletivo emergiu e, para compreendê-lo, fez-se necessário o estudo de seu entorno. Suas necessidades particulares tornaram-se públicas pois, ao se construir a história natural da doença do indivíduo, se identifica o que é comum aos demais membros daquela coletividade. A saúde é considerada então pública, mesmo que não necessariamente estatal.

No presente estudo, a saúde pública está sendo considerada como um campo 
onde circulam e se entrelaçam ações, comportamentos e práticas individuais ou coletivas, públicas ou privadas, indistintamente; campo este onde se insere a epidemiologia.

Cabem aqui algumas considerações de epidemiologistas de nosso tempo a esse respeito.

BREILH (1991) faz a distinção entre a saúde pública convencional e a saúde coletiva segundo vários aspectos. Toma a primeira como mais tradicional e a segunda como mais progressista. Estabelece novas bases para a saúde coletiva que propõe, não a restringindo ao processo saúde-doença como um fenômeno per se, mas como um processo coletivo determinado historicamente e, nesse movimento, incorpora o método materialista-dialético. A saúde coletiva, assim concebida, não está centrada na ótica estatal, mas a serviço das lutas populares, e é instrumento que visa a transformação social.

Para AYRES (1995a), saúde coletiva nomeia o conjunto das disciplinas ocupadas com o "social da saúde", tendo a epidemiologia um lugar realçado ou privilegiado entre elas (destaque do autor). A proposta do autor caminha no sentido de buscar a compreensão dessa disciplina, das suas responsabilidades e perspectivas no processo de construção de uma saúde efetivamente coletiva, sem se restringir às discussões estritamente metodológicas, nem à busca ao seu objeto. AYRES insiste no diálogo entre os saberes para expandir o horizonte interpretativo em que as contribuições teóricas convivem, mantendo suas fronteiras próximas, em interrelação, compondo-se em auxílio mútuo, com a possibilidade de confrontos onde houver superposição. Considera essa incursão epistemológica como uma necessidade para o desenvolvimento científico da epidemiologia, adentrando-se pelos caminhos da reflexão dos seus discursos para a compreensão dos valores implícitos nas práticas de saúde coletiva.

A aids, considerada em todas as suas dimensões e complexidade, reserva lugar para vários campos do saber, como já foi dito anteriormente. Numa análise das dimensões sociais da aids, COHN (1997), embora não trate especificamente de campos de conhecimentos, sugere: “... independentemente das características biológicas da doença, seu comportamento pandêmico na sociedade remete à complexidade da sua rede de transmissão, que tece sua trama numa imbricada 
interpenetração das esferas pública e privada da vida em sociedade" (p.46). A autora ressalta que há formas de transmissão que dependem de ações do Estado (controle da qualidade do sangue, por exemplo) e ações que são de natureza privada (práticas escolhidas pelo indivíduo). Essas últimas, para serem enfrentadas pela saúde pública, implicam uma invasão do universo da esfera privada, o universo das preferências individuais. Segundo ela, trata-se de um desafio duplo: a) dificuldade de compreensão da esfera psicológica que determina as diversas preferências individuais, de se expor a práticas de risco (sexual ou de outra ordem), de contrair e propagar a doença, consciente ou inconscientemente; b) ao abordar práticas de risco de trabalhadores do sexo e usuários de drogas injetáveis, há que se transitar entre as esferas da legalidade e ilegalidade, dificultando uma ação social eficaz.

Para ela, essas questões têm que constar na agenda das intervenções educativas, levando sempre em conta as esferas pública e privada, as dimensões sociais e individuais, sendo necessário o respeito aos direitos humanos dos cidadãos no que tange ao acesso às informações e à liberdade de escolha responsável de suas práticas e de seu destino. Que o sujeito individual, a partir de sua esfera privada, possa emergir como um sujeito social responsável na esfera pública e coletiva, o que é uma tarefa difícil numa sociedade tão díspare como é a brasileira.

Nesta perspectiva, entende-se que a visão compreensiva ou interpretativa da psicanálise a respeito do ser humano e de sua vinculação à sociedade ou sua inserção na coletividade torna-se relevante.

Em se tratando da aids, um problema de saúde pública — não só por ser um processo saúde-doença-morte, mas uma epidemia sem fronteiras, demandante de políticas de saúde, organização de serviços, esforços conjuntos e múltiplas pesquisas —, a incursão naquele campo (o da psicanálise) pode resultar proveitosa.

Pode ser possível a criação de um caminho, um campo comum às duas áreas em questão, por onde se possam fazer indagações, interpretações e alusões à forma como se processa a aids no sujeito individual e no sujeito coletivo. 


\subsection{A respeito da psicanálise...}

FREUD, ao criar a psicanálise, desenvolveu-a no sentido de dar conta do tratamento e cura de indivíduos neuróticos, a princípio as histéricas, abrindo um campo de conhecimento que se direcionou ao sujeito singular, pois priorizava a dupla analista-paciente e dava ao setting terapêutico uma especificidade particular. Entretanto, o próprio FREUD aspirava a um horizonte maior à sua teoria e isso fica evidente através de seus textos sociais ou antropológicos: "Totem e tabu” (1913), "Psicologia de grupo e a análise do ego" (1921), "O futuro de uma ilusão" (1927) e “O mal-estar na civilização" (1930), que são os que se direcionam mais claramente para o campo social e da cultura, e de citações como a que se segue.

\footnotetext{
"Não foi meu objetivo neste artigo colocar ante um público cientificamente orientado uma descrição do alcance e do conteúdo da psicanálise ou de suas hipóteses, problemas e descobertas. Meu objetivo terá sido atingido se eu tiver deixado claro as muitas esferas de conhecimento em que a psicanálise é de interesse e os numerosos vínculos que começou a forjar entre elas" (FREUD 1913, p.226).
}

FREUD, em 1923 [1922], define a psicanálise como um procedimento para a investigação dos processos mentais, quase inacessíveis por outro modo. Dessa investigação decorre o método de tratamento de distúrbios neuróticos e, do conjunto de informações psicológicas obtidas a partir dessa utilização, constitui-se a nova disciplina científica.

Considerada como uma arte da interpretação, revolucionou — de certa forma — a relação do médico com seu paciente, dando ao primeiro um lugar de "escutador" dos sintomas. A grande descoberta foi a de encarar os sintomas como substitutos significantes de atos mentais. "Tratava-se agora da questão de encarar o material produzido pelas associações do paciente, como se insinuasse um significado oculto, e de descobrir, a partir dele, esse significado"(FREUD 1923, p.291). Para isso, ficava à mercê de sua própria atividade mental inconsciente, observando com "atenção 
flutuante", à espera dos "ganchos", ou seja: conexões entre o conteúdo manifesto pelo paciente através das palavras, com o significado latente do mesmo. Com isso, evitava a preparação, a construção apriorística da demanda, a expectativa consciente, para poder ouvir o inconsciente do paciente a partir do seu próprio. Ao conseguir dar cabo dessa tarefa, traduzia para o paciente o significado, comunicando-o a ele - a interpretação.

A base teórica para essa técnica foi sendo construída aos poucos, a partir da própria prática e do que era comum aos diferentes tipos de pacientes com patologias semelhantes.

\subsubsection{A psicanálise na medicina: alguns percursos.}

A abordagem dos aspectos psicológicos das afecções somáticas não é recente. Entretanto, em várias fases da evolução da medicina, verificam-se idas e vindas, abandonos e recuperações de pensamentos, idéias, explicações, visando sempre a compreensão do processo saúde-doença e dos fatores a ele relacionados. Tanto isso é verdade, que há um movimento na Clínica Médica brasileira, representado pela sua sociedade, de incentivar os seus membros associados a adotarem a conduta de tratar o ser humano (o cliente) como um ser total, de uma forma holística e de discutir este assunto em suas reuniões científicas — principalmente de 1997 para cá.

Em recente publicação desta entidade, resgata-se os "Princípios fundamentais de Hipócrates: tudo observar, estudar o paciente antes da doença (partir do caso específico antes de classificar), examinar e descrever detalhadamente os sintomas, auxiliar o trabalho curativo da natureza (induzir à reação natural do organismo)". (SOCIEDADE BRASILEIRA DE CLÍNICA MÉDICA 1999, p.22).

Nessa publicação, faz-se, também, um percurso retrospectivo através da história da medicina, considerando os seus fatos mais marcantes.

Assinala-se que o século XIX foi marcado por grandes descobertas na medicina. Dentre elas, a bacteriologia ganha destaque não só pela descoberta dos micróbios e das associações às doenças específicas causadas por eles, mas também pelo advento das vacinas e estratégias de controle do contágio, que deram à humanidade a vitória sobre as grandes epidemias. 
$\mathrm{Na}$ virada do século XIX para o século XX, a descoberta do Raio X faz com que se priorize, de certa forma, o aspecto visível do interior do corpo humano. $\mathrm{O}$ “enxergar" a parte interna é um grande atrativo* e, a partir daí, a busca pela imagem, como acessório diagnóstico, passa a ser fundamental. Na seqüência, em 1971, viria a escanografia e a ressonância magnética nuclear, e a ecografia, em 1980.

Entretanto, é Sigmund FREUD (1856-1939), como mencionado acima, quem sugere a substituição da "visão" pela "escuta", tanto para o diagnóstico, quanto para o tratamento dos transtornos mentais. Aliando a mente ao corpo, através da psicanálise, a doença somática ganha outra dimensão, não só no que se refere aos distúrbios mentais eclodirem nos órgãos do corpo (a princípio, notadamente verificado nas histéricas), como também das doenças orgânicas provocarem, muitas vezes, alterações mentais.

\subsubsection{Franz Alexander e a Medicina Psicossomática}

Franz ALEXANDER, médico húngaro imigrando para o Estados Unidos da América, e lá sediando-se na Universidade de Chicago, na década de 30, começa a pensar sobre a questão das influências das experiências emocionais dos indivíduos no corpo, particularmente nas doenças, imbuído das idéias psicanalíticas freudianas.

Para ele, a medicina, como ciência natural autêntica baseada na aplicação dos princípios da física e da química ao organismo vivo, ignorou no século XIX a função psicológica do médico de apoiar emocionalmente o seu paciente e, através desse apoio, coadjuvar a cura pelo medicamento. "O reconhecimento de forças psicológicas, uma abordagem psicológica dos problemas de doença e da vida, parece, a alguns, um retorno à ignorância da Idade Média, quando a doença era considerada como o trabalho de um espírito mau e a terapia era o exorcismo, a expulsão do demônio do corpo enfermo" (ALEXANDER 1989, p.20).

\footnotetext{
${ }^{*}$ FOUCAULT (1994) assinala que o interesse pelo olhar para o interior do corpo humano data de meados do século XVIII, com BICHAT, que ultrapassando o limite da morte, busca na anátomopatologia as respostas para as indagações sobre as doenças dos organismos vivos. Repetindo as próprias palavras desse autor, confirma-se sua sugestão: "Abram alguns cadáveres: logo verão desaparecer a obscuridade que apenas a observação [dos enfermos] não pudera dissipar" (BICHAT citado por FOUCAULT 1994, p.168).
} 
É importante que se relate, resumidamente, algumas concepções desse autor. ALEXANDER considera que a fase da medicina em que se destaca o desenvolvimento laboratorial com as pesquisas em farmacologia, bacteriologia e cirurgia teve uma atitude eminentemente analítica. O detalhamento de mecanismos e a busca da compreensão de processos parciais, a busca de uma base etiológica da doença, localizada em determinadas partes do organismo e, finalmente, a descoberta da unidade microscópica da célula são para ele exemplos dessa atitude. E isso perdura até hoje, e as grandes descobertas dessa época na medicina, segundo este autor, obstaculizaram o advento de um outro tipo de abordagem da doença, de forma paradoxal: ao lado do avanço tecnológico verificado pelas descobertas científicas, nega-se todo um outro campo de saber útil à área, o psicológico. Isto é acompanhado de uma "crítica" à atitude dupla (ambivalente) do médico que, em meio aos seus colegas em encontros sociais, adota uma postura científica, privilegiando o saber da ciência físico-química e, na relação com o seu paciente, aconselha-o a não se preocupar, a evitar o excesso de trabalho e associa estes comportamentos à causa de doenças como a hipertensão arterial, por exemplo. Neste sentido, o método psicanalítico, se utilizado pela medicina, pode fornecer uma técnica eficiente para o estudo dos fatores psicológicos da doença. Observa-se que a importância do fator psicológico parece ser levada em conta instintivamente ao longo do tempo, na medida em que, conforme vai tendo mais experiência, o médico se apercebe de um conhecimento intuitivo, profundo e não verbalizado, que o acompanha em seus atos no exercício da profissão.

ALEXANDER tenta fugir da caracterização vigente na época, inspirada em VIRCHOV, de que não existem doenças gerais, mas doenças de órgãos, para tentar dar uma visão mais de conjunto do ser humano, através do que ele chamou de uma abordagem sintética.

Alguns distúrbios psiquiátricos poderiam ter um tratamento orgânico pelo psiquiatra, tal como qualquer outro distúrbio tratado pela medicina. Entretanto, a maioria das patologias mentais que se tentou tratar dessa forma não teve remissão (ou cura) satisfatória. O autor enfatiza a utilização do método psicanalítico como forma de tratamento não só dos distúrbios mentais, para além da psiquiatria tradicional, mas também de algumas doenças somáticas, para as quais escreve 
capítulos específicos. Nota-se certa tendência desse autor de colocar a psiquiatria como um campo à parte na medicina, pelo fato do tratamento desses distúrbios sofrerem procedimentos diferentes.

Para ALEXANDER (1989), “... o desenvolvimento da psicanálise pode ser considerado como um dos primeiros sinais de uma reação contra o desenvolvimento analítico e unilateral da medicina na segunda metade do século XIX, contra o interesse especializado em mecanismos detalhados, contra a negligência do fato biológico fundamental de que o organismo é uma unidade e de que a função de suas partes só pode ser compreendida do ponto de vista do organismo como um todo" (p.30). Assim, afirma a necessidade de tomar o ser humano como uma unidade ao tratar de seus males, sugerindo que não se negligencie o papel da mente no comando do corpo para o conhecimento do processo da vida. $O$ autor não negligencia, também, os mecanismos fisiológicos associados às funções mentais, dando-lhes muita ênfase, bem como os impulsos nervosos que surgem em determinadas situações emocionais e tem sua origem na interação entre as pessoas. Para ele, para se compreender essas respostas globais do organismo ao meio ambiente, só se pode lançar mão da psicologia.

Aplicando estas considerações a certos processos mórbidos do corpo, o autor introduziu, gradualmente, uma nova tendência na medicina, a medicina psicossomática. A uma determinada emoção, como por exemplo: tristeza e choro, alegria e riso, corresponde uma reação fisiológica. Quando o sentimento desaparece, a sua manifestação também cessa. Baseando-se em FREUD, ressalta: "O estudo psicanalítico de pacientes neuróticos revelou, no entanto, que distúrbios crônicos do corpo podem desenvolver-se sob a influência de distúrbios emocionais prolongados (...). FREUD introduziu o conceito de histeria conversiva, na qual desenvolvem-se sintomas corporais em resposta a conflitos emocionais crônicos" (ALEXANDER 1989, p.35).

Utilizando-se desse conceito, ALEXANDER faz uma comparação com o que ele denomina "neurose orgânica", cuja diferença seria a inibição ou alteração no funcionamento de um determinado órgão, ocasionado por influências de tensões emocionais. Essas disfunções não apresentariam nenhuma alteração morfológica nos tecidos dos órgãos, daí a hipótese de haver uma outra causa associada: a emocional. 
Na conversão histérica, o conteúdo psicológico motivador é inconsciente, criado pelo indivíduo de forma particular para expressar o que foi recalcado. Nas disfunções de órgãos, quando as influências emocionais cessam ou relaxam, as funções corporais voltam ao equilíbrio normal. Os sintomas de conversão histérica e as respostas orgânicas às emoções são semelhantes por serem respostas a estímulos psicológicos, mas diferem quanto à psicodinâmica e fisiologia. Ambas as doenças podem se beneficiar do tratamento psicoterápico adentrado ao campo da medicina e, não, restrito ao campo da psiquiatria. Nota-se novamente a separação feita pelo autor entre a medicina e a psiquiatria, enfatizando que a psicoterapia permite ao médico uma maior influência emocional sobre seu paciente e que ela pode encontrar lugar na medicina científica. A ênfase dada pelo autor visa a legitimação dessa forma de tratamento dentro da "arte médica".

Introduzindo uma nova concepção na investigação etiológica, ALEXANDER (1989) propõe que se principie pelo levantamento completo da história da vida do paciente que, muitas vezes, pode revelar as origens de distúrbios funcionais precoces, antes que o distúrbio da função tenha produzido alterações orgânicas histologicamente discerníveis. Segundo ele, muitas doenças incluídas no capítulo das Doenças Crônicas de Origem Desconhecida (do Código Internacional das Doenças CID) poderiam, talvez, serem enquadradas na categoria de distúrbios funcionais, sem que para isto haja uma alteração orgânica claramente discernível. Além disso, os fatores emocionais poderiam ser fatores etiológicos importantes em muitas disfunções endócrinas, funcionando como causas internas crônicas de doenças, independente de existirem fatores causadores externos agudos.

Os conflitos emocionais, que a psicanálise reconhece como a base das neuroses e como causa fundamental de certos distúrbios funcionais e orgânicos, surgem na vida diária, no relacionamento do indivíduo com o ambiente. Sentimentos como o medo, a agressão, a culpa, os desejos frustrados, quando reprimidos, geram tensões emocionais que perduram e perturbam as funções corporais. ALEXANDER considera evidente a influência desses conflitos e lhes atribui especificidades que tendem a atingir determinados órgãos internos, de forma análoga à afinidade específica com determinados órgãos que certos microorganismos patológicos também apresentam. 
O autor associa determinadas características de personalidade com determinadas funções corporais e reconhece a existência de relações entre as emoções e essas funções, cujo conhecimento é necessário ser incorporado pelo médico moderno, a partir do qual considerará, cada vez mais, os conflitos emocionais como sendo tão reais e tão concretos quanto os microorganismos visíveis. Como já realçado no início do capítulo, agora nas palavras do próprio autor: "A principal contribuição da psicanálise para a medicina tem sido a de acrescentar ao microscópio óptico um microscópio psicológico - isto é, uma técnica psicológica por meio da qual a vida emocional do paciente pode ser submetida à investigação detalhada (...) o conhecimento detalhado do relacionamento entre a vida emocional e os processos do corpo amplia a função do médico: o cuidado físico e mental do paciente pode ser coordenado no todo integral da terapia médica. Este é o significado real da Medicina Psicossomática" (ALEXANDER 1989, p.41, destaque do autor).

O termo "psicossomático" tenta evitar a dicotomia entre a mente e o corpo. ALEXANDER considera que, se se pensar nos fenômenos psicológicos como sendo os aspectos subjetivos de certos processos cerebrais fisiológicos, esta dicotomia deixa de existir. Ele acha importante definir bem o termo, para evitar equívocos decorrentes da própria terminologia, e esclarece a intenção fundamental de que a abordagem psicossomática abranja o uso simultâneo de métodos e conceitos somáticos (fisiológicos, anatômicos, cirúrgicos e dietéticos) de um lado, e os psicológicos de outro. É, neste sentido, que ele pretende superar a dicotomia, privilegiando ambos os aspectos ao mesmo tempo.

O autor acredita que, com o progresso da ciência, processos fisiológicos cerebrais poderão ser explicados com o auxílio de outros métodos e técnicas de diagnóstico (como a eletroencefalografia, por exemplo), porém, no momento em que faz essas considerações, há a necessidade de se recorrer à explicação dos processos cerebrais referentes aos relacionamentos interpessoais em termos psicológicos e sociológicos. Cabe um pequeno parêntese, para lembrar que, de meados do século XX para cá, os referidos métodos e técnicas evoluíram amplamente e, ainda assim, na virada do novo século, ainda há que se recorrer às explicações não só psicológicas e sociológicas, como também, às etnográficas, políticas, ambientais, etc, para a compreensão de determinadas doenças. Fala-se, hoje, em "crise de paradigmas" 
(ADORNO e CASTRO 1994) da investigação científica atual, buscando-se a concorrência de vários modelos não só de explicação, mas também de questionamentos, para melhor entendimento dos fenômenos, incluindo os processos saúde-doença.

ALEXANDER, ao se referir à classificação e diagnóstico da "doença psicossomática", elenca algumas mais comumente consideradas assim, tais como: a úlcera péptica, a artrite reumatóide, o hipertireoidismo, a hipertensão essencial, indicando que o fator etiológico proeminente é o psicológico. Entretanto, ao considerar a multicausalidade em vários ramos da medicina, levanta a possibilidade da concorrência de fatores emocionais interferindo na imunidade específica e inespecífica, na resistência do organismo à infecção, em doenças como a tuberculose, por exemplo. Neste sentido, o que o autor quer ressaltar é que o adoecer, em si, é um fenômeno complexo que pode depender parcialmente de fatores emocionais. Em conseqüência, diz: “(...) a tuberculose é uma doença psicossomática” (p.43-4). De certa forma, essa frase é um tanto "bombástica", em se tratando de uma doença causada por um agente etiológico conhecido - o bacilo de Koch. No entanto, inserindo as condições sob as quais o ser humano contrai a tuberculose e, seguindo os raciocínios multicausal e psicossomático, pode-se dar um certo crédito ao autor.

Inversamente, dar às doenças como a úlcera péptica, por exemplo, uma explicação meramente psicogênica não pode ser muito defendido, segundo ele, uma vez que as características emocionais típicas encontradas nos pacientes com essa doença são as mesmas observadas em pessoas que não sofrem de úlcera. Há fatores somáticos gerais ou locais que devem ser levados em conta. Para ALEXANDER, a formação da úlcera só pode ser explicada pela coexistência de ambos os tipos de fatores, os emocionais e os somáticos.

ALEXANDER propõe que se leve em conta, também, a influência muito variada destes fatores emocionais nos diferentes casos que invalida a conceituação de “doença psicossomática" como um grupo de diagnóstico específico. Em trabalho recente, ÁVILA (1995) afirma serem todas as doenças psicossomáticas e se respalda na redação do CID-10 que estabelece o não uso do termo psicogênico “... nos títulos das categorias, em vista de seus diferentes significados em diferentes línguas e tradições psiquiátricas (...) 'Psicossomático' não é usado por razões similares e 
porque o uso desse termo poderia ser tomado para implicar que fatores psicológicos não exercem um papel na ocorrência, curso e evolução de outras doenças, as quais não são assim chamadas" (Classificação Internacional das Doenças - CID-10 citado por ÁVILA 1995, p.11). No mesmo lugar, o autor tece uma série de considerações a respeito dessa posição da classificação das doenças, em que, segundo ele, “... os sintomas histéricos e psicossomáticos [são] tomados como manifestações secundárias de outros quadros".

Tal afirmação corrobora a colocação de ALEXANDER (1989, p.44): “Teoricamente, cada doença é psicossomática, uma vez que fatores emocionais influenciam todos os processos do corpo, através das vias nervosas e humorais".

ALEXANDER relaciona vários fatores que ele considera de importância etiológica da doença e estabelece uma verdadeira equação matemática ${ }^{*}$ em que um dos termos, a doença, é função de outro, sendo este múltiplo: os fatores. Esses últimos são todos relacionados com a história de vida do indivíduo doente a partir do seu nascimento, incluindo, desde a vulnerabilidade dos órgãos decorrente de doenças de infância, até as experiências emocionais tardias nas relações pessoais íntimas e/ou profissionais. O autor discrimina, claramente, aqueles fatores cuja importância foi evidenciada pela psicossomática e adicionada aos cuidados médicos. Salienta que “... a investigação psicossomática requer uma descrição precisa e detalhada das seqüências psicológicas, assim como requer uma observação precisa e detalhada dos processos fisiológicos correlatos. Estudos fisiológicos detalhados, que se correlacionam com descrições psicológicas impressionistas casuais, não podem contribuir para que conheçamos melhor a etiologia. Descrever uma perturbação da atividade cardíaca precisamente e explicá-la como sendo causada pelo nervosismo, sem uma descrição adequada do conteúdo emocional e ideativo, é algo sem sentido" (ALEXANDER 1989, p.44-5).

\footnotetext{
${ }^{*} \mathrm{D}($ doença $)=f($ função de $)\{\mathrm{a}, \mathrm{b}, \mathrm{c}, \mathrm{d}, \mathrm{e}, \ldots . . . \mathrm{n}\}$

a) constituição hereditária

b) traumas de nascimento

c) doenças orgânicas da primeira infância, que aumentam a vulnerabilidade de determinados órgãos

d) natureza do cuidado da criança na $1^{\mathrm{a}}$ infância (hábitos de desmame, educação esfincteriana, preparativos para o adormecer, etc)

e) experiências traumáticas físicas acidentais da $1^{\mathrm{a}}$ infância e das demais fases da infância

f) clima emocional da família e traços específicos da personalidade dos pais e dos irmãos

g) traumas físicos tardios
} 
Pode-se presumir que ALEXANDER propôs um estudo mais aprofundado dos processos mentais do indivíduo e da sua relação com a doença em questão, ao contrário de se estabelecer simplesmente uma ligação casual, por acaso ou superficial entre ambos.

Do ponto de vista prático, a base da abordagem psicossomática é um conhecimento tanto do funcionamento psicológico, quanto do corporal (somático). Neste sentido, a posição de ALEXANDER claramente delimita o campo da psicossomática à medicina, só podendo sua prática ser exercida por profissionais com formação médica. Assim, desde o diagnóstico, que para ele é médico, o profissional deve incluir em sua investigação clínica da história da doença, a história de vida do paciente. O desenvolvimento do sintoma e sua relação com conflitos emocionais, cronologicamente pareados a ele, devem ser identificados, para que se possa chegar ao que o autor denomina "diagnóstico psicossomático", para daí formular o plano de tratamento. Esse deve incluir uma atenção imediata ao sintoma físico - a doença em si.

Nesse processo, o autor reconhece a dificuldade inerente de se reconstruir toda a história da doença e sua associação com os fatores emocionais e, para isto, é fundamental a experiência psicanalítica e a cooperação entre os especialistas: psicoterapeuta e médico clínico. Considera “... de fundamental importância que o psicoterapeuta avalie até que ponto ele pode sobrecarregar o ego, com a revelação dos impulsos reprimidos. Em muitos casos, uma terapia de apoio superficial obtém sucesso no alívio dos sintomas, ao passo que a terapia profunda, compreensiva, pode levar a um agravamento da doença ou precipitar um episódio psicótico. Ao proporcionar uma terapia de apoio, o médico deve estar ciente da situação de conflito fundamental, a fim de adotar a abordagem correta" (ALEXANDER 1989, p.201).

É controversa a atitude sugerida pelo autor, em se tratando da postura psicanalítica, se não se considerar a psicossomática proposta como uma abordagem à parte, fora do campo psicanalítico, apesar da utilização dos conceitos e desenvolvimentos da psicanálise, em função da escuta analítica não ter uma atenção tão metódica, mas, sim, flutuante. Corroborando esta afirmação, encontram-se na literatura atual, relacionada à psicossomática, opiniões divergentes. ÁVILA (1995), propõe uma distinção entre a Medicina Psicossomática e a Psicossomática 
Psicanalítica apoiada não na base originária, que segundo ele, é a psicanálise freudiana e seu impacto na cultura e na etiologia das doenças, mas nos desenvolvimentos que contemplam propostas e resultados distintos uns dos outros. Esses desenvolvimentos e propostas diferem entre si tanto na elaboração do diagnóstico quanto na forma de tratamento do doente, não se tratando apenas de uma questão semântica. Como representante da Medicina Psicossomática, ÁVILA coloca ALEXANDER e a Escola de Chicago, e da Psicossomática Psicanalítica, GRODDECK, contemporâneo de FREUD. Nesta referência, o leitor encontra uma síntese de um dos livros de GRODDECK, sobre o qual o estudo de ÁVILA se baseia, além de um vasto desenvolvimento da abordagem da psicossomática psicanalítica às doenças.

Entende-se que o ser humano deve ser tratado em sua totalidade e que o sintoma fala por si mesmo, ou seja, possui uma linguagem própria que deve ser interpretada como sinal de algo para além dele mesmo, com um sentido e um significado a serem decifrados.

$\mathrm{Na}$ arte de curar da medicina se percebe que o medicamento sozinho não garante tudo. É necessário algo mais e esse algo se remete à presença do médico, não só como o prescritor, mas, também, como o sustentador. É através da relação médico-paciente que se operam as mudanças em direção ao restabelecimento da saúde. O vínculo passa a ser compreendido como mais um elemento da terapêutica.

A importância do pensamento de Franz ALEXANDER reside no fato de ele ter sistematizado, de forma bastante clara, preceitos e práticas médicos, aparentemente óbvios mas nem sempre percebidos, além de ter, de certa forma, "anexado" o campo psicanalítico à medicina, abrindo todo um modo de pensar a doença. Nas entrelinhas do trabalho analisado aqui, percebe-se todo um discurso no sentido de privilegiar as influências dos conflitos psicológicos na etiologia das doenças - e, para isso, utiliza os conhecimentos psicanalíticos — sem abrir mão, porém, de suas concepções médicas do funcionamento corporal orgânico. O resultado é uma imagem diversa da intentada, com a produção de um trabalho de grande valor, cuja crítica principal é, justamente, o estabelecimento de "perfis psicológicos" (MARTY 1993), de certa forma avessos e adversos às tendências e preceitos psicanalíticos. $\mathrm{O}$ próprio ALEXANDER se esquiva disso e, também, de atribuir determinadas características 
de personalidade a pacientes acometidos de determinadas doenças. Critica quem o faz, mas paradoxalmente, nem sempre é interpretado desta forma; isto é, é criticado por fazer o que condena. Talvez a forma de elaborar o diagnóstico proposta por ALEXANDER (o levantamento de fatores associados à doença) leve os seus críticos a pensarem que ele estabelece perfis psicológicos em sua abordagem às doenças.

Reconhece-se, no entanto, o valor de sua obra, pela fecundidade que suscita, através das pesquisas subseqüentes, e pela abertura e ampliação do campo da psicossomática, na medicina, com base na psicanálise.

\subsubsection{As concepções de Pierre Marty}

A aproximação das doenças somáticas pela psicanálise também é feita por outros representantes. Dentre eles encontra-se Pierre MARTY que, juntamente com um grupo de pesquisadores, desenvolve estudos sobre a psicossomática desde a década de 50 na França, onde é fundada a Escola de Psicossomática de Paris.

$\mathrm{Na}$ apresentação de seu livro “A psicossomática do adulto”, MARTY (1993) relembra as formas de obter a felicidade e evitar o sofrimento listadas por FREUD em "O mal-estar da civilização", de 1930: a realização no trabalho, as ilusões religiosas, satisfações amorosas, o uso de drogas e, por fim, a fuga para a doença nervosa (neurose e psicose). O autor aponta que, diante dos males vividos pelo ser humano nas suas relações com os imperativos da civilização, FREUD indica alguns "sedativos" para minimizar o sofrimento, deixando um caminho aberto não pesquisado, o da doença psicossomática.

O texto introdutório ao livro citado acima é escrito por Hanna KAMIENIECKI (1993) que se apóia nas concepções de MARTY, sustentando que as relações do corpo e do espírito, apesar de não totalmente compreendidas ainda, já contam com certo número de estudos e pesquisas. "Distinta da medicina, distinta também da psicanálise, da qual procede, e cujo campo de interesse amplia, a psicossomática hoje constitui uma disciplina em si. Sua especificidade reside nas respostas que traz ao velho debate sobre a unidade fundamental do ser humano" (KAMIENIECKI 1993, p.3).

Em relação à psicanálise, a psicossomática mantém uma referência permanente 
quanto à base teórica e clínica. Difere quanto aos pacientes que apresentam, às vezes, um empobrecimento da sexualidade diferente dos neuróticos, quanto aos objetivos que permitem ao paciente restabelecer seus mecanismos de defesa e a organização de sua sexualidade, quanto às técnicas que permitem as transferências laterais com outros profissionais de saúde, quanto ao ritmo das sessões, duração dos tratamentos, posição face a face com o paciente e relação transferencial modificada. Essas modificações da abordagem psicossomática em relação à psicanálise clássica visam dar conta das especificidades dos seus pacientes que, em geral, apresentam-se com as representações simbólicas (sonho, fantasia e discurso verbal) empobrecidas (MARTY 1993).

A psicossomática contribuiu com a psicanálise quanto a vários aspectos, dentre eles o desenvolvimento de seus conceitos no atendimento aos pacientes somáticos em vários graus de severidade de quadros e nos grupos de discussão de consultas e tratamentos.

Segundo o enfoque do grupo de Paris, a psicossomática como disciplina exerce um papel importante no tratamento das doenças somáticas, colaborando com a medicina e tornando-se sua parceira. Não se restringe, e nisso difere da concepção de ALEXANDER referida no capítulo anterior, aos profissionais médicos. É extensiva aos profissionais com formação iniciada em psicanálise e direcionada, posteriormente, para a psicossomática. Essa, por sua vez, direciona-se a todos os setores da medicina para se somar, especialmente em setores como a imunologia, por exemplo, que evidencia especificidades individuais dos pacientes, requerendo esse tipo de abordagem.

No livro citado acima, após uma breve revisão histórica dos trabalhos desenvolvidos na França, MARTY (1993) apresenta suas concepções baseadas na evolução desses estudos na disciplina psicossomática, enquanto forma de diagnóstico e tratamento das doenças. Cita especialmente as cefalalgias, raquialgias e alergias, fornecendo explicações sobre o funcionamento mental dos pacientes acometidos por essas enfermidades.

$\mathrm{O}$ autor relata a permanência de uma certa expectativa dos interessados nesse campo em descobrir estruturas psicossomáticas relacionadas a certos funcionamentos psíquicos e as afecções físicas por eles determinadas, a exemplo da 
proposta americana. Ligando essa expectativa diretamente à alergia, a suposição de haver um "tipo mental alérgico" não se verificou. De forma semelhante à de Franz ALEXANDER, encontrou pacientes com as mesmas características de funcionamento mental do paciente alérgico que, entretanto, não apresentavam esse tipo de manifestação somática.

A descrição feita por MARTY (1993) do funcionamento mental dos sujeitos por ele tratados baseia-se nos princípios econômicos e dinâmicos da metapsicologia* freudiana, levando em conta a teoria do desenvolvimento libidinal, com suas fixações e posteriores regressões. O autor assinala uma distinção nos movimentos de regressão ou de desorganização dos pacientes em função da constituição do psiquismo de cada um. O diagnóstico, prognóstico e indicação terapêutica, para ele, são decorrentes dessa avaliação. MARTY (1993) distingue o funcionamento psíquico dos pacientes psicossomáticos do funcionamento psíquico dos pacientes neuróticos. Em função disso, surgiram seus trabalhos envolvendo os novos conceitos nosográficos: "Pensamento operatório" (MARTY 1962), "Depressão essencial" (MARTY 1966) e "Desorganização progressiva" (MARTY 1967), que serão apresentados a seguir.

O pensamento operatório é descrito pelo autor como um pensamento consciente que carece de atividades fantasmáticas e oníricas. Essa carência altera a saúde física e é acompanhada de perturbações somáticas. O pensamento operatório não é investido libidinalmente e suas ligações são com as coisas e não com as palavras, daí a não conexão com produtos da imaginação e expressões simbólicas, sugerindo um “... processo de investimento de nível arcaico” (MARTY 1993, p.17).

Faz-se uma pequena pausa para introduzir a noção de representação de coisa e de palavra para melhor compreensão das concepções de MARTY.

\footnotetext{
* Em FREUD, o termo metapsicologia possui dois sentidos: o primeiro relaciona-se ao conjunto de modelos conceituais que são a base teórica da psicanálise e o segundo estabelece ligações entre a metapsicologia e a metafísica, com o sentido de transformar essa última em psicologia. Acrescenta-se: “... proponho que, quando tivermos conseguido descrever um processo psíquico em termos dinâmico [circulação da energia dentro do aparelho psíquico], topográfico [localização nesse aparelho] e econômico [os investimentos libidinais em instâncias, representações e objetos], passemos a nos referir a isso como uma apresentação metapsicológica"(FREUD citado por GARCIA-ROZA 1996, p.113-4).
} 
De acordo com a teoria psicanalítica, a representação de coisa está relacionada ao sistema inconsciente. Consiste “... num investimento, se não de imagens mnésicas diretas da coisa, pelo menos no de traços mnésicos mais afastados, derivados delas" (FREUD citado por LAPLANCHE e PONTALIS 1970, p. 585).

A representação de palavra liga-se aos sistemas pré-consciente e consciente. Ela associa a imagem mnésica à imagem verbal, e é constituída a partir dos relacionamentos humanos, primeiramente com a mãe. É mobilizada pelo afeto e pelos valores simbólicos, sendo a base das associações de idéias.

O conceito de representação permeia continuamente a descrição feita por MARTY (1993) sobre os processos de somatização. O sistema pré-consciente ocupa um lugar central por ser ele o regulador do funcionamento psicossomático e dos recursos mentais do sujeito, realizando as ligações entre as representações de coisa e de palavras (VOLICH 2000).

Em 1980, MARTY substitui o termo “pensamento operatório" pela expressão "vida operatória", tendo o autor, com isso, o objetivo de abranger também os comportamentos decorrentes desse tipo de funcionamento mental.

Segundo MARTY (1993), verifica-se neste tipo de paciente poucas e pobres representações, persistindo um funcionamento automático, com uma cessação das condutas anteriores perversas e sublimatórias e uma desorganização profunda que acarreta a insuficiência em vários setores da vida psíquica. Preconiza-se a psicoterapia aliada ao acompanhamento médico.

A partir da noção "operatória", MARTY sistematizou outras noções que vieram a ser mais freqüentes em termos da clínica dos pacientes somáticos em associação aos seus quadros clínicos. Nesse sentido, “depressão essencial”, que se relaciona à precariedade do trabalho mental, foi o termo criado (em 1966) pelo autor em substituição ao termo depressão sem objeto (destaques do autor). Observa-se nesse quadro um “... rebaixamento de nível do tônus libidinal sem qualquer contrapartida econômica positiva" (MARTY 1993, p.19). Os sintomas definem-se pela falta de libidinização, pelo apagamento da dinâmica mental, determinado por essa falta, que pode levar à desvitalização ou à morte (destaque do autor). Nas palavras de MARTY (1993, p.19): “O instinto de Morte é o Senhor da Depressão Essencial”. O grau de agravamento para o sujeito é diretamente proporcional à 
quantidade de tempo vivido em estado de depressão essencial. Segundo o autor, existe um quantum de traumatismo que o indivíduo pode elaborar mentalmente. $\mathrm{O}$ excedente é que se traduz nesse tipo de sintomatologia e pode acarretar afecções somáticas pela insuficiência de representação.

As desorganizações progressivas, definidas como “... a destruição da organização libidinal do indivíduo em um dado momento" (MARTY 1993, p.20), são impeditivas do movimento regressivo nas fases evolutivas e acarretam a desordem de funções somáticas que podem chegar à ruptura do equilíbrio vital.

As conceptualizações teóricas e clínicas de MARTY seguem integralmente as noções freudianas, as quais recapitula de forma sumária ao esboçar sua "economia psicossomática" (destaque nosso). Assim são abordados: a teoria das pulsões (vida e morte), as fases de organização da libido (o desenvolvimento infantil), os fenômenos de fixação e regressão, o funcionamento dos sistemas inconsciente, pré-consciente e consciente, as representações e suas associações com a noção de mentalização (ou o quantum de traumatismo o psiquismo suporta elaborar). É a própria metapsicologia freudiana, por demais vasta e complexa para ser desenvolvida neste curto espaço e tempo. Ater-se-á, apenas, naquilo que os processos de somatização descritos por MARTY (1993) fizerem referência a ela, havendo ciência do efeito fragmentário e lacunar deste tipo de exposição.

Segundo o autor, a psicossomática consegue resolver boa parte das doenças somáticas revertendo o quadro e possibilitando uma evolução favorável. No entanto, no caso das doenças graves, considera que a psicossomática ainda não pode identificar as razões do desenvolvimento de uma determinada doença em um indivíduo e não de outra. MARTY (1993) exemplifica com os questionamentos: por que um indivíduo desenvolve um câncer e não uma doença auto-imune, por que um câncer em determinado órgão e não em outro?

O que o autor constata ser comum às doenças somáticas é que elas ocorrem por inadequação do indivíduo às suas condições de vida, às quais ele tem que tentar adaptar-se continuamente. Para essa adaptação, o adulto utiliza-se do aparelho somático, da essência arcaica e do aparelho mental em interação. Numa nova situação conflitiva, se os dois últimos, de forma conjunta, não forem suficientes para produzir a adaptação do indivíduo, o aparelho somático é chamado a responder. O 
traumatismo corresponde, para MARTY, à ultrapassagem das possibilidades de adaptação, havendo, portanto, um esgotamento dessa capacidade. Em termos psicanalíticos, isso corresponde à não elaboração mental ou não representação dos fatores acidentais das experiências, interferindo diretamente na constituição do sujeito.

Os exemplos de traumatismos dados pelo autor são: “... perda de um ente querido, de uma função profissional ou familiar, perda de uma relação sexual ou de amizade, perda de um grupo ao qual se pertença, mas também perda de um sistema de vida anterior, perda de uma liberdade, perda de uma função fisiológica (menopausa, amputação, por exemplo) ou mental (no envelhecimento, por exemplo), de um funcionamento sexual..." (MARTY 1993, p.45, nota de fim). Pode-se acrescentar a perda da imunidade decorrente da infecção pelo HIV, como mais um exemplo de traumatismo nos moldes da proposta desse autor.

As situações traumatizantes provocam o aumento das excitações pulsionais ou, ao contrário, sua diminuição ou, eventualmente, ambos em associação. Dessa forma, pode haver a desorganização dos aparelhos funcionais que são atingidos pelo traumatismo, sendo o aparelho mental primeiro a ser atingido. Quando esse aparelho encontra-se em um bom estado de constituição - a partir de um bom desenvolvimento infantil e de uma boa estruturação psíquica, com a economia e a dinâmica dos sistemas inconsciente, pré-consciente e consciente em adequado funcionamento - , os mecanismos de defesa têm mais condições de operar e de favorecer uma boa elaboração do luto, podendo ter a chance de não produzir a desorganização e não atingir a esfera somática. O problema central das somatizações, segundo MARTY (1993), é o fluxo das pulsões agressivas e sexuais, que devem corresponder às necessidades atuais do indivíduo e estarem de acordo com suas experiências passadas, nem sempre havendo essa adequação. "Os obstáculos ao fluxo conveniente das excitações provêm habitualmente: no seio do aparelho mental, ou de uma insuficiência fundamental do sistema pré-consciente das representações, ou de uma desorganização psíquica por fragilidade desse sistema, ou de inibição, de evitações ou de repressões das representações, ou da precedência de um Ego-ideal*

\footnotetext{
* O ego ideal é um conceito freudiano que designa “... um ideal narcísico de onipotência forjado a partir do narcisismo infantil (...). No decurso do desenvolvimento, o indivíduo deixaria atrás de si este
} 
entravando qualquer regressão" (MARTY 1993, p.31).

O autor coloca os processos de somatização em dois pólos extremos. No primeiro, encontram-se as desorganizações somáticas, com as doenças evolutivas e desorganizações progressivas, associadas às neuroses mal mentalizadas, às neuroses de comportamento e às neuroses de mentalização incerta. As neuroses de caráter mal mentalizadas são conseqüência de distúrbios de intensidade e duração variáveis ocorridos anteriormente, acarretando um funcionamento precário do pré-consciente que, na seqüência das experiências de vida do indivíduo pode produzir perturbações. As neuroses de comportamento caracterizam-se por falhas no desenvolvimento infantil que têm como conseqüência a expressão direta dos impulsos inconscientes por meio da ação. "Nas neuroses de comportamento, a má mentalização, a fragilidade do Ego, das defesas mentais e da organização edípica e a precariedade do sistema regressões-fixações favorecem o desenvolvimento das desorganizações progressivas, as descargas pelo comportamento e o aumento do risco de uma doença orgânica de maior ou menor gravidade" (VOLICH 2000, p.148). As neuroses de mentalização incerta oscilam entre uma boa e uma má mentalização, tanto em relação às variações quantitativas e qualitativas dos recursos representativos observados na consulta, quanto em relação à interpretação do terapeuta das situações de vida anterior do paciente (VOLICH 2000). No segundo pólo colocado por MARTY (1993), estariam as regressões somáticas que originam as doenças reversíveis, semelhantes às regressões mentais e associadas às neuroses bem mentalizadas. Essas neuroses correspondem às psiconeuroses descritas por FREUD: neurose obsessiva, fobias, histeria e certas psicoses. O indivíduo apresentaria uma boa organização mental decorrente do seu desenvolvimento infantil, com defesas neuróticas consistentes e baseadas no uso de recursos egóicos de enfrentamento das situações de conflito. O autor considera que o indivíduo pode, mesmo assim, desorganizar-se ao sofrer uma forte tensão ou excitação traumática, podendo ser acometido por uma doença grave. Isso dependerá de fatores internos e externos em interação.

ideal narcísico e aspiraria regressar a ele..." (LAPLANCHE e PONTALIS 1970, p.190). Para MARTY (1993, p.29) o ego ideal representa “... um 'todo' de invulnerabilidade ou um 'nada', já que o fracasso diante da realidade se acha vivenciado como uma ferida narcísica (desorganizadora da esfera somática, pois não existem possibilidades mentais de recuo) e não como uma culpabilidade negociável, o Ego-ideal se mostra eminentemente mortífero". 
A separação entre esse dois pólos, entretanto, não é tão nítida frente ao aspecto clínico das somatizações, mas serve como referência para a avaliação de cada paciente em um dado momento de sua vida.

Segundo MARTY (1993), as somatizações são acompanhadas de uma alteração do funcionamento mental e de depressão. A duração das desorganizações é variável e, em geral a somatização cessa quando cessam os movimentos desorganizadores e a depressão essencial, desencadeantes e mantenedores das doenças, bem como com o fim do peso dos traumatismos. Com uma psicoterapia bem conduzida por um profissional experiente em psicossomática há uma mudança psicoafetiva do estado dos pacientes.

O autor reflete também sobre a necessidade de se construir uma classificação psicossomática das doenças, na qual se pode basear para realizar os diagnósticos e acompanhar a evolução dos pacientes, mas mais do que isso, para organizar o saber e favorecer a comunicação entre os profissionais. Em dado momento no curso dos trabalhos desse autor, essa classificação foi realizada, o que permitiu a avaliação do paciente segundo sua estrutura fundamental, suas particularidades habituais, suas características atuais maiores, suas novas características resultantes da psicoterapia. MARTY (1993) considera que esse instrumento cria possibilidades de discussões e trocas entre os profissionais e no interior de grupos de pesquisa.

Para finalizar, cumpre ressaltar uma das conseqüências da importância dessas concepções no meio psicanalítico brasileiro. Em São Paulo, em 1993, foi criado o Curso de Psicossomática Psicanalítica do Instituto Sedes Sapientiae visando oferecer uma formação sistemática inspirada nos desenvolvimentos da Escola de Psicossomática de Paris. De lá para cá, esse núcleo tem prosseguido no trabalho de formação de profissionais médicos, psicólogos e psicanalistas e também na produção de conhecimentos, tendo alguns títulos publicados pelos seus membros. Vem de uma dessas publicações a afirmação: “A originalidade de MARTY está na constatação de que a capacidade de assimilação mental tem limites e que esses são maiores ou menores conforme os indivíduos, e em um mesmo indivíduo, conforme o momento da vida” (VIEIRA 1997, p.16), extraída do núcleo das idéias expostas neste capítulo. 


\subsubsection{Interfaces}

A partir dos desenvolvimentos feitos por MARTY e ALEXANDER, algumas articulações entre os campos de conhecimento podem ser pensadas, em busca de um terreno comum para se pensar o objeto do presente estudo.

Algumas reflexões de OLIEVENSTEIN (1989) e de BIRMAN (1994) são introduzidas para enriquecer este diálogo. $\mathrm{O}$ primeiro pondera sobre o que subjaz às práticas médicas e à relação médico-paciente e à doença e, o segundo, sobre as fronteiras da psicanálise com outros saberes.

OLIEVENSTEIN (1989) afirma que existe sempre uma relação do sujeito com a sua doença e isso é mais claramente observado no caso das doenças psicossomáticas, nas quais o fenômeno biológico se submerge ante o fenômeno afetivo. Dependendo do tratamento dado pelo médico no alívio da dor, o sentimento particular e subjetivo associado a ela pode ser ultrapassado ou passar desapercebido. Ocorre uma luta íntima entre o sujeito consigo mesmo, que, para o autor, está associada à crença histórica de que a doença inferioriza e desvaloriza em diversos graus.

OLIEVENSTEIN (1989) considera que há uma hierarquia entre as doenças, sendo algumas mais nobres e outras mais inferiorizantes, fazendo surgir coisas inconfessáveis, segredos e atitudes de resignação ou de revolta. É o que ele chama de "não-dito" e que está relacionado ao doente, ao médico e à equipe de tratamento. Segundo ele, depois de FREUD o não-dito pode ser negociado através da passagem do papel de tratado (paciente/submisso) ao papel de quem trata (médico/curador), pela transferência ou vínculo terapêutico. Observa-se nessa dinâmica, da parte do médico, a tentativa de demonstrar poder sobre a morte e, da parte do doente, a tentativa de se ligar a um sintoma que lhe serve, em alguma medida, como fonte de prazer. É um interjogo de atitudes e sentimentos em torno da doença, ocultando interesses, desejos e conveniências, não-ditos, “... envolvendo a doença, o doente, os que cuidam dele, numa guerra de movimentos onde nada é neutro nem inocente" (OLIEVENSTEIN 1989, p.131). As dimensões desses movimentos são em nível individual, dual e social, colocando o doente num universo de significados já estabelecidos pelo "estar doente" ou, no caso da aids, por "ser um doente de aids". 
O não-dito está implícito, interrompendo o fluxo das palavras, e colocando o sujeito num lugar predestinado. O percurso até os afetos ocultados e os lugares não permitidos encontra suas vias de acesso através da escuta do terapeuta (seja em consulta, seja em tratamento), o que lhe permite entrar em contato com as próprias sensações e fantasias (contratransferencialmente), resgatando ao sujeito as palavras e os sentidos.

O combate à doença, não necessariamente restringe-se à prevenção, etiologia ou tratamento, mas às formas de diminuir o mal-estar, a angústia, a recordação e lembrança de fatos outrora vividos, não compreendidos e ressurgidos nas estatísticas e na falta de controle de doenças como a aids e no que tudo isso invade cada um: o médico, o doente e a sociedade, em nível mais amplo. Nesse nível coloca-se em debate a utilização do instrumental psicanalítico.

Enquanto campo de conhecimento, a psicanálise tem contribuído também para explicar fenômenos que ocorrem fora do espaço do setting (situação dual de análise), voltando-se para o cotidiano da sociedade em geral. BIRMAN (1994, p.7) desenvolve esse tema, ressaltando a possibilidade do “... estabelecimento de um diálogo interdisciplinar da psicanálise com algumas das ciências humanas." A interlocução pode ser fecunda, operando-se nas fronteiras da psicanálise com outros saberes que abordam temáticas comuns e similares, saindo do isolamento para o diálogo.

Segundo o autor, a psicanálise no Brasil era excluída do diálogo com outras disciplinas até os anos sessenta. Houve a implantação de espaços interdisciplinares, onde ela foi convidada a comparecer e aceitou, inclusive para não correr o risco de comprometer seu campo conceitual. Esta incursão da psicanálise para além das fronteiras tradicionais de seu campo, de acordo com BIRMAN, só faz sentido se o movimento de saída for acompanhado, em contrapartida, de um movimento de retorno. Reconhece, assim, o limite epistemológico que define um campo e a possibilidade de aumento da consistência do mesmo a partir do regresso de outros campos. Acrescenta que estas explorações possibilitam o aparecimento do novo e inédito: “... é o problema escolhido pelos diferentes saberes que será o canal para o diálogo entre as disciplinas, enquanto essas impõem a construção de problemáticas pela mediação de seus conceitos específicos (destaques do autor). Com isso, pode-se 
realizar a produção de conhecimento, a constituição de positividades inéditas e elaboração de novos conceitos" (BIRMAN 1994, p.9).

O valor de uma proposta desse tipo é o de permitir a convivência da diversidade, na pluralidade de posições teórico-clínicas e sociais que constituem o campo. Essa convivência nem sempre é harmônica e isenta de conflitos entre posições teóricas que atuam no mesmo campo ou em campos diferentes. É o fenômeno humano o problema comum entre as diversas disciplinas. A partir da clínica psicanalítica, cria-se um dispositivo para dar conta de certas necessidades de natureza individual. Pode-se utilizar, também, da psicanálise como um dispositivo a serviço do sujeito coletivo. De modo que, nesse âmbito - o coletivo —, possa-se refletir sobre as negações, recusas e recalques inerentes e subjacentes à epidemia da aids, possibilitando o registro do que se teme e se oculta. Assim, o que surgiu quase como um sintoma - concebido como formação de compromisso, com deformações e substituições - pode manifestar-se e ser compreendido. Retrata-se e relembra-se aqui o mal-estar provocado massivamente pelo anúncio dos primeiros portadores do vírus HIV, muitos já doentes de aids, e a forma de identificação e focalização da pessoa infectada como sendo o não-eu, o negado.

Como se verificou no relato histórico da epidemia, a aids tornou-se presença concreta, perante a qual se teve que responder/agir. Agora não mais fantasia localizada no outro, no fora de mim, no diferente, foi se transformando no eu, através da infecção da massa, do igual a mim. Deixou de ser um sintoma individual, para ser um sintoma social.

Assim, enquanto um problema de saúde que envolve toda a população, a aids pode receber uma parcela da contribuição psicanalítica e da teoria da interpretação, da qual se tratará no capítulo metodológico.

Alguns autores vêm dedicando-se ao objeto aids e psicanálise, e é sobre as suas produções que o presente estudo versará. Esses trabalhos dão pistas dos caminhos de reflexão possíveis que se pode percorrer. Uma proposta deste tipo é um desafio, de cujo enfrentamento não se pode furtar, mesmo sabendo das adversidades da tarefa. Uma sistematização como a que se propõe, neste estudo, é necessária, tanto do ponto de vista pessoal, no sentido de conhecer as contribuições e possibilidades de interlocução dos campos envolvidos, quanto para a comunidade científica que passa 
a ter acesso a um banco de informações disponíveis e com os conteúdos articulados entre si. A procura é por ligações entre os pensadores do objeto em estudo que possam ser compartilhadas, com a expectativa de se deparar com uma diversidade de percursos e caminhos que permitam a possibilidade de diálogo e interlocução favorável à construção de uma epistemologia sobre o assunto, podendo daí advirem novas soluções para este novo que já vai se constituindo um velho problema.

Torna-se então necessário se debruçar sobre o material existente para conhecêlo, visando o estabelecimento de conexões significativas entre os seus conteúdos.

\subsection{A proposta de revisão bibliográfica}

Ao se aproximar desta abordagem metodológica, verifica-se a existência de algumas revisões bibliográficas relativas ao assunto aids, tanto no Brasil, como no exterior. $\mathrm{O}$ objeto aids em conexão com a psicanálise não faz parte destes estudos que serão assinalados a seguir, em ordem cronológica.

Em "5 anos de bibliografia sobre AIDS/SIDA: 1981-1985", LACAZ e GOMES (1986) acompanharam a literatura desta "epidemia do século" (destaque dos autores) para se atualizarem quanto aos “... aspectos clínicos, epidemiológicos, virológicos e imunológicos ...” (p.5) da doença. Suas fontes foram os periódicos à disposição na Biblioteca do Instituto de Medicina Tropical de São Paulo (relacionados no Anexo 1), todos de natureza médica, seguindo uma apresentação cronológica dos artigos ano a ano e em ordem alfabética dos autores. Listaram, ainda, livros, capítulos de livros, teses e dissertações publicados de 1983 a 1986, na mesma seqüência. Reuniram 2290 títulos de trabalhos nacionais e internacionais. Dentre as produções nacionais, foram incluídos também trabalhos oriundos de comunicações em eventos.

Observando os estudos reunidos pelos autores, verificou-se a existência de dez trabalhos, cujos títulos constam do Anexo 2, envolvendo aspectos psicológicos e um, os psicopatológicos. Na observação dos títulos em detalhe - dentre eles um brasileiro - , há indícios de que se tratam de questões relativas aos cuidados e atitudes frente ao doente de aids, à crise psicológica desencadeada pelo diagnóstico, aos serviços de apoio comunitários, além de relatos de experiências no atendimento aos pacientes. 
BUENO e col. (1993) fazem uma revisão da produção, em língua inglesa, de artigos e resumos sobre aids disponíveis na base de dados MEDLINE, no período de 1986 ao $1^{\circ}$ semestre de 1992, totalizando 704 trabalhos. Os resultados apontam que a maioria (92) está relacionada com o tema educação e prevenção (85), hospitalização (83) e saúde da mulher (80). Os demais temas dispersam-se, não aparecendo nesse estudo a categoria aspectos psicológicos e afins. Os autores sugerem que profissionais que se interessam pela questão da aids desenvolvam estudos envolvendo aspectos carentes apontados por essa pesquisa, tais como o trabalho com a população adolescente, por sua vulnerabilidade à doença.

Em se tratando de adolescentes, GRUNSETT e KIPPAX (1993) levantaram os estudos produzidos (cerca de 1050 artigos) nas bases de dados (listadas no Anexo 3) de fontes de língua inglesa. O resultado é o documento "Efeitos da educação sexual dos jovens" (tradução nossa). Examinaram surveys transversais, intervenções e desenhos quase-experimentais e construíram um quadro de análise envolvendo categorias como: número de participantes (tamanho da amostra), tipo de desenho e resultados (impacto sobre o comportamento após um programa de prevenção). As autoras consideram que essa pesquisa não foi exaustiva. Foi realizada a partir dos anos 70 e, portanto, tratam-se de intervenções educativas pré HIV/AIDS. As autoras consideram, entretanto, que as recomendações para uma educação sexual eram as mesmas das que se sucederam ao HIV/AIDS.

LOVATO e col. (1997), fazem uma revisão envolvendo pesquisas de recrutamento de pessoas para a participação em ensaios clínicos controlados. Consideram uma extensão e revisão de um trabalho similar realizado uma década antes e publicado na mesma revista. Discutem questões pertinentes a esse tema, tais como: custo, barreiras culturais (língua, costumes, etc) para o recrutamento de populações, aderência ao protocolo, confidencialidade, dentre outros aspectos.

Em artigo recente, FOULKES (1998) provê um resumo dos desenvolvimentos na área de metodologia estatística e matemática nas respostas à epidemia do HIV/AIDS, da última década. Seu propósito foi o de investigar a perspectiva histórica até o momento para identificar necessidades futuras.

Apesar de não abordar os temas psicanálise e aids, SOARES (1989) realizou uma extensa e exaustiva revisão bibliográfica em outro campo de conhecimento no 
Brasil, na qual se pode basear para agir metodologicamente, pois se trata de um trabalho completo e criterioso. A autora salienta que “... a multiplicidade de perspectivas e a pluralidade de enfoques (...) não trarão colaboração realmente efetiva enquanto não se tentar uma articulação das análises provenientes de diferentes áreas de conhecimento...” (p.2). Além disso, para a autora, torna-se indispensável dar um passo nesse sentido, para se evidenciar as perspectivas, análises, estudos e pesquisas, e obter uma noção do "estado do conhecimento" ou “estado da arte" em nosso País.

Transpondo essa contribuição para o presente estudo, é importante investigar até que ponto e, a partir de que ponto na história da epidemia, os autores que trabalham com a psicanálise enquanto campo teórico e método de tratamento se interessaram pela questão do HIV/AIDS e suas conseqüências para o ser humano.

Qual é o estado do conhecimento nesse campo de estudo?

Qual tem sido a contribuição da psicanálise nesse campo de estudo?

Quais os enfoques dados? Quais as linhas teóricas das contribuições?

Houve mudança de enfoque nos textos e pesquisas? Em que isso pode determinar transformações na própria perspectiva psicanalítica?

Quais são os autores mais direcionados para este tema?

Tem havido reflexões acerca de alternativas para lidar com a dor psíquica provocada pela condição de soropositividade?

Existe uma preocupação dos psicanalistas em reordenar este campo de conhecimento face ao impacto causado pela demanda da aids, ou as teorizações a seu respeito são decorrentes e inseridas na própria teoria psicanalítica?

São questões a partir das quais se pode percorrer caminhos de análise da evolução histórica da produção de conhecimento em psicanálise associada ao HIV/AIDS, no início, no decorrer e nos dias atuais desta epidemia e das formas possíveis de se lidar com ela, de acordo com as obras encontradas, tanto em nível coletivo quanto em nível individual, para que se possa avançar em direção à solução deste grave problema de saúde pública.

Metodologicamente, a opção pela revisão bibliográfica é convidativa, como ponto de partida para a análise e reflexão dos percursos entre os dois campos: a saúde pública e a psicanálise diante da aids no Brasil. 
A relevância de um estudo desse tipo consiste no fato de poder contribuir para a compreensão do estado atingido pelo conhecimento do tema aids, em associação à psicanálise, permitindo visualizar sua amplitude, tendências teóricas e vertentes metodológicas. Essa compreensão, tendo-se transcorrido quase duas décadas desde o início da notificação dos primeiros casos da doença, é necessária no processo da evolução da ciência e na conjunção de saberes, a fim de que se ordene e sistematize a produção de conhecimento em áreas aparentemente tão autônomas e dispersas, se promovam tentativas de compreensão e prevenção e se identifiquem posições, lacunas e vieses. 


\section{OBJETIVOS}

\subsection{Objetivo Geral}

O presente estudo tem por objetivo verificar o estado do conhecimento envolvendo o tema psicanálise e aids no âmbito da produção literária brasileira referente à saúde pública e à psicanálise.

\subsection{Objetivos Específicos}

2.2.1. Identificar os aspectos no processo de construção do conhecimento em questão que têm sido privilegiados e/ou negligenciados.

2.2.2. Evidenciar as linhas de atuação dos estudos e pesquisas envolvendo as duas áreas.

2.2.3. Levantar a necessidade de definição de novas linhas de pesquisa. 


\section{METODOLOGIA}

Como o material de análise é constituído de textos, insere-se, agora, um capítulo envolvendo considerações a respeito do estatuto da interpretação, cotejandoas com aquelas da compreensão e da explicação.

\subsection{Interpretação, compreensão e explicação.}

Conforme já mencionado no capítulo da trajetória da epidemia da aids, o período atual é o de busca incessante de formas de explicação das multideterminações e sentidos desse agravo à saúde. Nada mais natural e conveniente que a utilização de técnicas interpretativas não só de fatores, mas de "sujeitos" da epidemia. E "sujeitos", nesse caso, abrangendo tanto os indivíduos acometidos pelo HIV/AIDS, como os sujeitos do conhecimento, os pesquisadores (no caso, os psicanalistas) que tomaram como objeto de estudo o fenômeno aids, com as suas vertentes e determinações, para compreendê-lo. Interessa saber como os pesquisadores/psicanalistas intervieram nesse campo dotado de múltiplas facetas e símbolos. Interessa saber quais as abordagens utilizadas, os conteúdos significativos e o solo epistemológico sobre o qual eles apoiaram as suas interpretações. Interessa ainda, conhecer quem são essas pessoas, quando e quais experiências desenvolveram, que recursos utilizaram para falar da face psicanalítica do fenômeno epidemia da aids.

Essas considerações cumprem o papel de dar significado à experiência de compreender. São interpretativas. Uma interpretação dá-se através das associações do pesquisador, que se embrenha pelo caminho composto de trilhas da construção de um saber, no qual tem que realizar paradas, saltar obstáculos e entrar em veredas. São os meandros da elaboração do texto em que o autor, nesse caso também intérprete (dos textos), vai aparecendo em suas intenções, na medida em que introduz as colocações de outros intérpretes a respeito do seu objeto de estudo: a psicanálise e a aids.

Antes de adentrar-se na análise do material colhido, é conveniente que se 
façam alguns desenvolvimentos sobre a interpretação, a compreensão e a explicação, enquanto partes de um processo de busca de significados, de apreensão de um conteúdo discursivo. Não existe, entre os pensadores que se preocupam com essa temática, uma forma consensual de se conceber a tarefa de interpretar. Nem de como se articulam e se distinguem as fases que constituem esse processo que coloca em contato, no discurso escrito, duas subjetividades (a do escritor e a do leitor) e, entre elas, o texto. Há todo um percurso em direção à interpretação com vistas à compreensão do conteúdo impresso no texto, para o qual se necessita do auxílio de instrumentos de sinalização. Ainda assim, o intérprete arrisca-se a um desnorteamento no meio do caminho.

Por essas razões, neste capítulo, propõe-se uma discussão através das colocações de diversos autores - FOUCAULT, RICOEUR, GADAMER, e RORTY —, visando uma compreensão possível da arte de interpretar, como a denominam alguns (FREUD, RICOEUR).

Sobre a interpretação, como já foi dito, não existe uma colocação unívoca. Sendo assim, algumas apropriações a respeito desse assunto valem a pena serem comentadas.

FOUCAULT (1997) expressa seu sonho de um dia ver constituído uma espécie de corpus geral contemplando todas as técnicas de interpretação, de todos os tempos. Sob essa idéia fundamental, propõe-se a analisar o que subjaz à linguagem das culturas indoeuropéias — focaliza MARX, NIETZSCHE e FREUD —, adiantando que está atento ao significado que está encerrado na linguagem (nem sempre é o manifesto), e às falas que subtraem o discurso verbal. Falas que, mesmo não verbais, são ouvidas e dizem algo. Dentre elas, encontra-se a doença que fala através do corpo.

Segundo FOUCAULT, esses pensadores, cada um a seu modo, colocaram a si mesmos e aos seus contemporâneos, diante de uma nova possibilidade de hermenêutica. Causaram incômodo ao mostrar que o homem, ao se utilizar de técnicas de interpretação, interpreta a si mesmo e se defronta com a própria ferida narcísica. Diz FOUCAULT: "Interrogo-me se não se poderia afirmar que FREUD, NIETZSCHE e MARX, ao envolverem-nos numa interpretação que se vira sempre para si própria, não tenham constituído para nós e para os que nos rodeiam, espelhos 
que nos reflitam imagens cujas feridas inextinguíveis formam o nosso narcisismo de hoje" (FOUCAULT 1997, p.17).

FOUCAULT prossegue sua reflexão a respeito desses autores, indagando-se sobre a extensão e profundidade das transformações de sentido e significado dos símbolos provocadas por eles, e constata que, na verdade, eles não tiraram nada do lugar, nem agregaram nada, mas sim modificaram a natureza do que ali já estava e a forma de interpretação. Ao fazerem isso, promoveram a diferenciação dos símbolos.

Para bem compreender esses sistemas de interpretação, FOUCAULT remete-se ao século XVI, cuja base de interpretação era a semelhança, com suas noções definidas e organizadas: a conveniência, ou o ajuste, o emulatio, o paralelismo dos atributos em substâncias (entre uns e outros), a signatura, a assinatura que representava para o indivíduo a imagem oculta e invisível, e a analogia, a identidade de relações entre duas ou mais propriedades da substância. O conhecimento fazia-se pelo cognitio (o trânsito de uma semelhança a outra) e o divinatio (o aprofundamento de uma semelhança superficial para uma mais profunda). Essas semelhanças opunham-se ao simulacrum (a falsa semelhança).

Após um certo "hiato" de dois séculos, com FREUD, NIETZSCHE e MARX, as técnicas de interpretação voltam à cena, com o impacto enfatizado por FOUCAULT. Em função do objetivo do presente estudo, centralizar-se-á a questão da interpretação na hipótese freudiana, tal como considerada por esse autor, apesar da construção de sua análise contemplar os três autores, colocando-os, analogamente, lado a lado.

Um primeiro aspecto ressaltado é a elevação da interpretação ao estatuto de tarefa infinita. Leia-se: terreno fértil e promissor como campo de explicação e compreensão da existência humana ou ainda, caminho sem fim. Segundo FOUCAULT já era assim também no século XVI, mas a semelhança com que os símbolos eram interpretados era, em si, limitada. Ao contrário, a partir do século XIX, a interpretação dos símbolos em cadeias transformou-se numa rede inesgotável, infinita e inacabada, evidenciada no caráter de desenvolvimento regressivo e analítico de FREUD. O autor considera que, quanto mais se avança na interpretação e se aproxima de uma região perigosa ou conflitiva, ela vai encontrar o início do seu retrocesso. Vai ainda desaparecer como interpretação, podendo chegar, inclusive, ao 
desaparecimento do intérprete. Como exemplo, FOUCAULT cita a análise dos sonhos de FREUD, bloqueada pelo seu pudor em "descobrir" mais, o caso Dora, esbarrado no caminho do deciframento pelo que veio a se chamar mais tarde transferência, e o próprio trabalho analítico, pelo seu caráter de interminabilidade.

Baseado nessas considerações, FOUCAULT extrai alguns postulados da hermenêutica moderna em que: “... se a interpretação não se pode nunca acabar, isto quer simplesmente significar que não há nada a interpretar (...) nada absolutamente primário a interpretar, porque no fundo já tudo é interpretação, cada símbolo é, em si mesmo, não a coisa que se oferece à interpretação, mas a interpretação de outros símbolos" (FOUCAULT 1997, p.22). Para ele, FREUD interpreta interpretações e não símbolos. Parece redundante essa fala, mas FOUCAULT está referindo-se ao sintoma que é a matéria trazida à interpretação pelo doente através de sua linguagem. Em certo sentido, referindo-se a FREUD, o autor parece dizer que, na modernidade, nada é pedra bruta "objetiva". Interpreta-se lançando mão de conceitos e teorias forjados ao longo da história, seja por quem for, em que modos e em que circunstâncias. Esse "forjados" pode ser traduzido por "interpretações" de alguém, com a sua subjetividade e seus laços sociais, trazidas para a intersubjetividade do campo científico. E com NIETZSCHE é o intérprete o verdadeiro “... que pronuncia a interpretação que toda a verdade tem como função recobrir. Talvez seja primazia da interpretação em relação aos símbolos o que dá um valor decisivo à hermenêutica moderna" (FOUCAULT 1997, p.24). Para FOUCAULT, frente à obrigação de interpretar-se infinitamente, a interpretação, inevitavelmente, encontra a si mesma, volta para si mesma, de forma circular.

Recorrendo a outros autores, pode-se buscar uma forma de compreender melhor a questão da interpretação. RICOEUR (1978) realizou um vasto estudo sobre a hermenêutica, no qual analisa, dentre outras, a obra de FREUD. Refere-se à metapsicologia como uma construção facultativa mas calcada na experiência, o que lhe confere um caráter de descoberta. Assim, a tópica freudiana com seus sistemas consciente, pré-consciente e inconsciente, é o que possibilita a decifração dos conteúdos, tal como uma arqueologia que vai se aprofundando camada por camada, para revelar o que está enterrado.

Relacionando a hermenêutica ao inconsciente, RICOEUR afirma: “... a 
realidade do inconsciente é constituída na e pela hermenêutica, num sentido epistemológico e transcendental. (...) não é uma relatividade à consciência que aqui é afirmada, uma relatividade subjetiva, mas a relatividade puramente epistemológica do objeto psíquico descoberto à constelação hermenêutica formada conjuntamente pelo sintoma, pelo método analítico e pelos modelos interpretativos" (RICOEUR 1978, p.92).

O sucesso terapêutico confere à psicanálise e ao inconsciente a sua realidade, e à interpretação o lugar de método, segundo RICOEUR, através do qual desvela-se um saber.

Na cultura contemporânea, a psicanálise insere-se como um movimento que visa dar uma explicação sobre o homem, sobre a cultura e a constituição dos laços entre os homens, operando transformações no mundo à medida que o interpreta.

Segundo RICOEUR, com as incursões que a psicanálise fez, ela abalou domínios tradicionais utilizando seu modelo próprio (sua tópica centrada na força do inconsciente). A interpretação psicanalítica é global — porque se aplica a todo ser humano, e limitada - porque não vai além da totalidade do seu modelo.

RICOEUR destaca a não pretensão de FREUD em fornecer uma explicação exaustiva, mas uma explicação pelas origens e pela economia das pulsões, limitando sua visão a um ângulo, mas abrindo à totalidade do fenômeno humano. Isso quer dizer que, do ponto de vista enfocado por ele, seu olhar atingiu as profundezas do ser humano. Na opinião desse autor, a etiologia das neuroses e a hermenêutica da cultura encontram uma certa reciprocidade. "Interpretar significa ir de um sentido manifesto a um sentido latente: a interpretação se move inteiramente em relações de sentido e só compreende as relações de força (recalque, retorno do recalcado) como relação de sentido (censura, despistamento, condensação, deslocamento); por isso, ninguém contribuiu mais que FREUD para romper o charme do fato e para reconhecer o império do sentido" (RICOEUR 1978, p.125) (destaques do autor).

O autor considera que o modelo de explicação descoberto por FREUD foi inscrito no contexto positivista e, ao mesmo tempo, o arruína. Nesse sentido, rompe uma tradição. Por outro lado, com sua linguagem de uma hidráulica mental mantém um papel conservador de explicação, gerando uma certa ambigüidade enquanto modelo de explicação. Para RICOEUR (1978, p.125-6), é necessário que se faça uma 
composição da metapsicologia freudiana com os estilos da hermenêutica contemporânea, especialmente com o da fenomenologia dos mitos e dos símbolos. Tentando dar um lugar à psicanálise na contemporaneidade, RICOEUR, tal como FOUCAULT, chama NIETZSCHE e MARX para emparelhar-se com FREUD no seu interesse quanto à tomada de consciência do homem moderno. Aponta nos três a colocação da consciência sob suspeita e da ilusão como sua comandante. Lembrando da dúvida cartesiana sobre as coisas, mas não sobre a consciência, em FREUD, MARX e NIETZSCHE, duvida-se da consciência. RICOEUR não os considera céticos, e sim, destruidores. Destroem para depois fundar e construir. A partir dessa coordenação de pensamentos, para o autor, poder-se-á avançar na arte da interpretação — que é em si, a própria construção. "Descartes vence a dúvida sobre a coisa pela evidência da consciência. Eles vencem a dúvida sobre a consciência por uma exegese de sentido. A partir deles, a compreensão é uma hermenêutica: doravante, procurar o sentido, não é mais soletrar a consciência do sentido, mas decifrar suas expressões" (RICOEUR 1978, p.127). Com essa afirmação, RICOEUR já está adentrando na concepção de que algo mais existe sob o que é revelado. Freud ao criar a tópica inicial, define um pouco esse algo que existe: são instâncias que operam num jogo incessante com o inconsciente pulsando constantemente com a consciência. A interpretação terá como tarefa principal o seu deciframento através de suas expressões. O seu sentido só será desvelado desta forma. E assim, a psicanálise galga degraus para a compreensão da experiência humana.

Em outro trabalho, RICOEUR (1976) faz a distinção entre explicação e compreensão. A primeira originária do campo das ciências naturais, e a segunda, tendo seu campo de aplicação nas ciências humanas, em que se verifica um intercâmbio entre sujeitos. E é através desses sujeitos que perpassam e se expressam os discursos a serem compreendidos. No foco de interesse do presente estudo, destacam-se os escritos. Para o autor, essa é a forma indireta de transmitir as experiências, produtos da vida psíquica de cada um. A interpretação é um modo de obter-se a compreensão. Essa dirige-se para a intenção do discurso e a explicação, volta-se para a estrutura analítica do texto. Para RICOEUR, explicação e compreensão são pólos de uma dicotomia que se dialogam no processo dinâmico da leitura interpretativa. Expressa sua discordância em relação à máxima da 
hermenêutica romântica "compreender um autor melhor do que ele a si mesmo se compreendeu" (Kant citado por RICOEUR 1976, p.87), por considerar que a intenção do autor está além do alcance do leitor, pois o texto é em si um desprendimento para um lugar não psicológico, mas semântico. Ao texto será construído um sentido que parte sempre de uma conjetura do intérprete, que poderá ser confirmada ou não com os procedimentos de validação, o uso da lógica da probabilidade, por exemplo, que não garante nem certeza nem verificação. A interpretação de um texto processa-se em um círculo entre a conjetura (pólo da compreensão) e a validação (pólo da explicação), sendo sempre possível confrontar, arbitrar ou argumentar a favor ou contra uma interpretação.

Passando a desenvolver a mesma dialética da compreensão e explicação, agora no sentido inverso, RICOEUR cita a análise dos mitos realizada por LÉVISTRAUSS, em que toda a estrutura de parentesco é dividida (mapeada) em unidades constituintes, denominadas por ele mitemas (como os fonemas) que depois são organizadas em feixes de relações. Da mesma forma pode ser feito com o texto, cujas unidades (as frases) são compostas para formar a narrativa global. Trata-se de realizar uma análise estrutural que será um momento entre uma interpretação ingênua e uma interpretação crítica, situando a explicação e a compreensão em dois estágios diferentes de um único círculo hermenêutico. Cabe lembrar que está presente um movimento de olhar o texto como um todo, além de transitar pelas suas partes de forma complementar.

$\mathrm{O}$ autor conclui seus ensaios atribuindo uma importância fundamental à apropriação pelo leitor do sentido do próprio texto, mais do que da intenção do autor ou das circunstâncias históricas e sociais nas quais ele foi escrito. Para ele, o texto é o acontecimento, tem o poder de desvelar o mundo.

Cotejam-se as colocações desse autor, ao lado das de outros autores a respeito da tarefa hermenêutica.

"GADAMER nos diz: A melhor definição da hermenêutica é deixar que aquilo que foi alienado pela natureza da palavra escrita ou pelo fato de haver se distanciado por questões culturais ou históricas, fale de novo" (GADAMER citado por BERNSTEIN 1991, p.77). Essa colocação parece estar de acordo com a questão das muitas interpretações que se pode fazer de um texto, já referidas neste capítulo. 
GADAMER continua: “O intérprete não trata mais do que de compreender esta coisa universal, o texto; isto é, de compreender este fragmento de tradição, que é o que constitui o significado e a importância do texto. Com o objetivo de compreender isto, não deve omitir a si mesmo e a sua situação hermenêutica particular" (GADAMER citado por BERNSTEIN 1991, p.76). Do ponto de vista de GADAMER, parte-se da concepção de fusão de horizontes: os do texto aos do leitor, os do leitor aos do texto.

RICOEUR (1976) aborda a questão da universalidade do texto de que fala GADAMER. RICOEUR afirma que um texto não é dirigido apenas a um âmbito específico de leitores, mas é uma espécie de objeto atemporal que se desprende da cadeia histórica na qual foi constituído. O autor é favorável a esse "anti-historicismo" (destaque dele), na medida em que ele tem como pressuposto principal a objetividade da significação em geral. É o texto que se interpõe entre o escritor e o leitor, fazendo a mediação. Essa colocação soa como o "permitir que o texto fale de novo" de GADAMER. E que fale quantas vezes for solicitado! Para alguns autores isso se dá de forma interminável: “... algumas das principais correntes do pensamento crítico contemporâneo [J. DERRIDA, P.DE MAN e J. HILLIS MILLER] (...) parecem dar licença ao leitor de produzir um fluxo ilimitado e incontrolável de leituras" (COLLINI 1997, p.9).

Pode haver um distanciamento no tempo e no espaço, mas a palavra escrita, inscrita no texto, é o elo de ligação entre o autor e o leitor. É o seu significado e a sua compreensão que se busca atingir. O próprio RICOEUR (1976) concorda com a fusão de horizontes de GADAMER, assumindo também uma posição favorável à ampliação de horizontes para além da situação existencial do autor, através do desvelamento feito pelo leitor.

Essas alternativas de análise são promissoras e satisfatórias para dar conta das indagações e inquietações suscitadas pelo texto, e para permitir uma elaboração mental dotada de sentido.

RORTY, a partir da citação de GADAMER em que ele afirma que "Compreender e interpretar é sempre compreender e interpretar de maneira diferente..." (RORTY apud BERNSTEIN 1991, p.98), acusa-o de buscar um consenso. O consenso do qual o autor fala supõe-se ser o consenso da utilização da 
hermenêutica como método, como uma aplicação de procedimentos a partir dos quais se permite chegar aos mesmos resultados, à mesma compreensão. O termo compreensão sendo entendido, aqui, como GADAMER o define: um processo constituído por três momentos: a interpretação, a compreensão e a aplicação, e não no sentido considerado por RICOEUR, acima.

GADAMER parece realizar uma busca do conhecimento a partir da phronesis, ou sabedoria, de uma situação prática particular não transferível ou não aplicável a uma outra. Há um tipo de conhecimento prático com um certo trânsito entre o universal e o particular. A fusão de horizontes apontada por GADAMER, talvez seja o ponto que sugere a RORTY a extensão da situação hermenêutica ao consenso de uma comunidade de intérpretes.

A fusão de horizontes sugere também a RICOEUR (1976), a ampliação da compreensão, não na forma de consenso como expôs RORTY, mas na forma de universalidade de sentido: "O sentido de um texto está aberto a quem quer que possa ler. A onitemporalidade da significação é o que a abre a leitores incógnitos. (...) porque o texto subtraiu-se de seu autor e à sua situação, subtraiu-se igualmente ao seu endereçado original. (...) O alargamento do âmbito, de leitores é a conseqüência da transposição inicial do primeiro evento para a universalidade de sentido" (RICOEUR 1976, p.105).

O autor exclui o apelo de "pessoa a pessoa" da apropriação que se faz do texto, deixando claro que não se trata de coincidir com a psique alheia, mas sim com o “genuíno poder referencial do texto”. Segundo ele, “... a idealidade do texto é o vínculo mediador neste processo de fusão de horizontes" (RICOEUR 1976, p.105).

RORTY, em contrapartida, opõe-se a qualquer tentativa de encerrar-se a discussão por meio de um consenso interpretativo. Sua hermenêutica constitui-se numa espécie de luta contra as abordagens que tentam dar uma dimensão comensurável a um dado discurso. No entanto, encontram-se em seus textos algumas colocações de quem não é tão alheio assim, às interpretações dadas a um determinado discurso, e sim leva em conta algumas construções de sentido. Sua desconstrução não se refere a um processo de destruição, mas antes, de compreensão e reconstrução. Para isso, prescreve o diálogo como forma de mediação e instrumento para chegar-se à verdade, à verdade que não é finita, nem infalível. São 
ilustrativas dessas considerações: "Eu diria que um texto tem apenas a coerência que por acaso adquiriu durante a última volta na roda da hermenêutica, assim como um monte de barro tem apenas a coerência que por acaso obteve durante a última volta do torno do oleiro" (RORTY 1997, p.115). O autor cita ECO na parte em que esse autor refere-se ao universo da semiótica ser o universo da cultura humana e sobre a forma como isso se estabelece:

“... a) [o universo] é estruturado de acordo com uma rede de intérpretes.

b) É virtualmente infinito porque leva em conta as múltiplas interpretações realizadas por diferentes culturas... é infinito porque todo discurso sobre a enciclopédia lança dúvidas sobre a estrutura da própria enciclopédia.

c) Não registra apenas verdades, mas antes o que se disse sobre a verdade ou o que se acreditava sobre a verdade...” (ECO citado por RORTY 1997, p.117).

RORTY expressa literalmente sua concordância com ECO nessa colocação.

Diante de posições como as que foram expostas, que se distanciam e se aproximam a todo o momento, como se deve posicionar o intérprete? Parece estar aberto o caminho ao relativismo. Não o relativismo opcional e perigoso referido pelos críticos de RORTY - GADAMER e HABERMAS — “... a forma [de relativismo] em que o inquieto espírito da negatividade dialética converte-se em uma potente força para a destruição irrestrita" (BERNSTEIN 1991, p.99); mas aquele da abertura ao diálogo incessante que torna o discurso científico contemporâneo, em si, uma verdade relativa, uma atitude crítica que consiste em questionar as verdades aceitas, considerando-as como verdades construídas a partir de uma cultura dominante (ROUDINESCO 2000, p.116, nota de rodapé).

Ao fazer uma leitura de um texto, uma obra de arte, uma teoria, uma situação interpessoal, um problema de saúde, o intérprete já está implicado na dialética do próprio processo de construção do conhecimento, pois algo o conectou a esse cenário; portanto, ele não pode "escapar" de ser incluído. Ele mergulha num universo de elementos constituintes de verdades científicas com os quais tem que conviver, fazendo opções que melhor atendam às suas indagações, e vivenciando momentos de tensão entre o novo e o velho aos quais tem que se ajustar. O sentimento perene é de inquietação e incerteza, suportadas pela opção da companhia de autores tão controversos como RORTY, citado por FIGUEIREDO (1999, p.13): “... interpretar 
não é nada além de contextualizar (...) O que importa são os contextos (sistemas de crenças, desejos, expectativas e interesses) do leitor [que] preexistem a qualquer interpretação (...) enfrentando sem muitos transtornos novos elementos da experiência". O autor adverte que o leitor, frente ao novo, pode sofrer um abalo nas próprias convicções e sistemas de crenças que ficam tensos. Esses, por vezes, requerem uma reconstrução através da inclusão de novos contextos que visem dar sustentação ou sentido aos novos elementos recuperando a consistência e estabilidade. "O leitor, assim procedendo, opera uma transformação em si mesmo, sem sair de si na direção de um além de si" (FIGUEIREDO 1999, p.14) (destaques do autor).

Essa teoria pode ser utilizada na busca de um olhar para o que está subentendido no discurso. São seres humanos falando sobre seres humanos. Vai-se em busca de saber do que se está falando quando se diz algo, através da compreensão da mensagem discursiva escrita.

\subsection{Procedimentos de coleta e organização dos dados}

A pesquisa bibliográfica, visando a ordenação e sistematização do conhecimento, foi realizada por meio de procedimentos diversos e complementares. De um lado, efetuou-se uma busca sistematizada, rigorosamente formalizada, iniciando-se pela elaboração de uma listagem das bases de dados para a coleta de material e por outro, uma busca assistemática e, conseqüentemente, mais informal.

A pesquisa abrangeu os artigos de periódicos indexados nas Bases de Dados: MEDLINE - National Library of Medicine's, PSICLIT - PsycINFO Database, da American Psychological Association, SOCIALFILE - Cambridge Scientific Abstracts/Sociological Abstracts e LILACS - Literatura Latino-Americana e do Caribe em Ciências da Saúde, dissertações e teses de mestrado e doutorado de universidades brasileiras, livros e capítulos de livros dos catálogos oficiais de bibliotecas científicas: DEDALUS - Sistema Integrado de Bibliotecas da Universidade de São Paulo, BIREME - Sistema Latino-Americano e do Caribe de Informação em Ciências da Saúde, UNIBIBLI - Sistema de Bibliotecas das Universidades Paulistas, INTERNET - Bibliotecas virtuais: Saúde Reprodutiva, 
Indexpsi e Ibict, e comunicações em eventos publicadas integralmente.

As dissertações e teses incluídas na presente pesquisa foram obtidas através do catálogo de teses do Instituto de Psicologia da Universidade de São Paulo e da biblioteca da Pontifícia Universidade Católica de São Paulo. Alguns endereços eletrônicos de bibliotecas de universidades fornecem dados de teses, além dos sites http://www.ct.ibict.br:81/site/admin/, http://www.cnpq.br/, http://www.prossiga.br. Nesse último está incluída a Biblioteca de Saúde Reprodutiva. Esse tipo de busca, porém, trouxe algumas referências de trabalhos, cujo acesso nem sempre foi possível em decorrência de fatores de ordem prática, como por exemplo, a falta de comutação bibliográfica entre algumas bibliotecas. Portanto, na impossibilidade de obtenção dos trabalhos acadêmicos de outros estados brasileiros, as teses e dissertações analisadas foram exclusivamente provenientes de universidades paulistas, predominantemente da Capital.

Os trabalhos nomeados e referendados que, a despeito das tentativas de busca permaneceram indisponíveis, constam do Anexo 4, a quem possa interessar e/ou para fins de contatos futuros. Dentre eles, apenas um se trata comprovadamente de estudo envolvendo o referencial psicanalítico (CAMPOS 1996), dado que com essa pesquisadora já se havia estabelecido um contato prévio em uma aula, em que foi citado seu texto. Dos demais, além do título, não se tem nenhum dado para avaliar suas abordagens.

A pesquisa informal envolveu uma busca de artigos publicados em fontes não indexadas provenientes de instituições de formação em psicanálise, de revistas especializadas em psicanálise e de contatos com núcleos de pesquisa em aids e pesquisadores que trabalham com o tema, utilizando a correspondência eletrônica como veículo (vide modelo no Anexo 5). Através da pesquisa informal, foi tentado também ter acesso às referidas produções acadêmicas, verificando-se uma ausência de retorno às correspondências enviadas. Algumas instituições, mesmo não possuindo material disponível, sugeriram nomes de pesquisadores e trabalhos de provável interesse para o presente estudo, sendo também muito significativo o apoio de profissionais envolvidos com o tema investigado, formando uma espécie de "rede de cooperação".

Da mesma forma, o trânsito em eventos, cursos e disciplinas interinstituições 
de ensino favoreceu esse tipo de troca, empreendendo-se uma verdadeira cruzada que, muitas vezes, remeteu às mesmas fontes. A suspeita inicial de quase inexistência de material impôs esse tipo de busca persistente e insistente e, o "quase nada" transformou-se em uma fonte de pesquisa expressiva. As limitações levantadas não encerram o trabalho de pesquisa. Pelo contrário, deixam uma porta aberta que abre horizontes para a complementação em estudos futuros. Salienta-se a importância do caráter rigoroso da coleta de dados, através dos instrumentos sistemáticos (indexes), convivendo lado a lado com o caráter casual (ou do acaso) que alia criatividade e flexibilidade ao método, imprimindo ao estudo uma certa intuição.

O período pesquisado abrangeu 1981 a 2000. A data inicial foi marcada pelas primeiras discussões a respeito da nova enfermidade, abordadas no capítulo 1 (item 1.1.a). A primeira publicação encontrada data de 1987, definindo o início do período. Trata-se de um artigo de periódico. A última publicação, uma tese de doutorado defendida em abril de 2000, definiu a data final do levantamento. A última busca foi efetuada em julho do mesmo ano.

A pesquisa foi feita por assunto, com o uso de unitermos partindo do geral para o particular. As primeiras investigações se referiram aos termos HIV/AIDS e psicanálise, na literatura médica, psicológica, antropológica e de saúde pública. Sob o tema "aids", as ocorrências eram numerosas (por volta de 18000) no Medline. Sob o tema "psicanálise", por volta de 900 ocorrências. Na intersecção dos termos e tomando como língua de origem o português, a ocorrência era quase nula (1 no Medline e 2 no Psiclit). Iniciou-se, assim, uma "busca truncada" (usando o termo "Psic\$" para incluir todos os derivados desse radical) e por subtemas, como narcisismo, pulsão de vida, pulsão de morte, identidade, identificação, self, etc, que, aplicados à literatura médica e de saúde pública, capturariam os trabalhos em psicanálise, dados serem esses, conceitos-chave na teoria psicanalítica. Em contrapartida, foram cruzados termos específicos da aids, tais como: prevenção, soropositividade, tratamento e autocuidado em todas as buscas.

No Lilacs, obtiveram-se 120 ocorrências utilizando-se os termos Psicológico e aids, das quais 9 tratavam-se de estudos em psicanálise feitos por autores brasileiros. No catálogo de teses da USP foram obtidos 9 trabalhos e na PUC-SP 7, excluindo-se posteriormente os não psicanalíticos. 
Por indicação bibliográfica — textos referidos nas fontes primárias analisadas - obtiveram-se 11 trabalhos que constam do Anexo 6, dos quais, 6 foram analisados e, dentre esses, 4 foram obtidos também por outras vias. Os 5 textos restantes encontram-se dentre os textos indisponibilizados, já relacionados no Anexo 4.

O restante dos trabalhos foi obtido, aqui e ali, nos contatos e trocas já explicitados, e através de bibliografia particular acumulada ao longo da experiência com a questão da aids no campo da psicanálise e da saúde pública.

O universo das produções analisado ou corpus - "conjunto dos documentos tidos em conta para serem submetidos aos procedimentos analíticos" (BARDIN 1995, p.96) - é o de publicações realizadas no Brasil, escritas por autores brasileiros, envolvendo os temas psicanálise e aids. Foram obtidos 60 trabalhos, fontes primárias deste estudo. Após leitura e catalogação em ficha técnica padronizada (modelo exposto no Anexo 7), excluíram-se 10 textos (relacionados no Anexo 8): 3 por terem sido escritos por autores estrangeiros e 7 por não utilizarem o referencial psicanalítico no desenvolvimento de suas questões, ambos critérios de exclusão da pesquisa. Os 50 documentos selecionados (corpus), constam da Bibliografia: Fontes Primárias de Pesquisa e foram indexados em fichas técnicas padronizadas que se encontram no Anexo 9. Optou-se por organizar os trabalhos na seqüência cronológica, com a finalidade de estabelecer possíveis paralelos com os diversos momentos no curso da epidemia, com a construção do conhecimento acerca da doença e verificar em que momento houve a incursão dos psicanalistas neste campo.

Utilizou-se a técnica de análise de conteúdo, entendida como um conjunto de instrumentos metodológicos aplicados a conteúdos discursivos para o conhecimento do processo de produção da mensagem, tentando ir além do seu conteúdo manifesto com o uso da inferência. Trata-se de um esforço teórico para analisar o dado de forma a "... ultrapassar o nível do senso comum e do subjetivismo na interpretação, e alcançar uma vigilância crítica frente à comunicação de documentos, textos literários, biografias, entrevistas ou observação" (MINAYO 1994, p.203). Nesse tipo de procedimento oscila-se entre dois pólos: o objetivo e o subjetivo (BARDIN 1995). Segundo essa autora, o primeiro cercado de rigor, e o segundo de fecundidade. O pesquisador é instigado à busca do oculto, escondido, latente, não-dito da mensagem. 
O conteúdo das publicações foi analisado mediante a construção de categorias de análise definidas antes de um primeiro olhar sobre os dados coletados. Para GOMES (1994), uma categoria refere-se a um conceito que envolve elementos ou aspectos com características comuns ou que se relacionam entre si. Agrupam-se, assim, idéias, conteúdos e elementos sobre os quais se faz a análise e interpretação do material. $\mathrm{O}$ autor aconselha a definição das categorias mais gerais antes da coleta de dados e as mais específicas e concretas após a mesma. No presente estudo, as categorias foram construídas a partir dos objetivos da pesquisa, do conhecimento do campo psicanalítico e do perfil da epidemia de aids. Cada um dos textos foi analisado segundo estas categorias:

O referencial teórico dentro da psicanálise: o quadro teórico em que sua proposta se desenvolve.

A instituição envolvida: de onde se originou o estudo.

A natureza do texto: o tipo de abordagem ao fenômeno da aids, se o texto consiste de relato de experiência, desenvolvimento de pesquisa ou reflexão sobre o tema.

Os temas dos textos: os aspectos do fenômeno em que o autor se detém.

Em seguida, após a leitura e catalogação dos textos em fichas técnicas, de acordo com as categorias mencionadas, foram estabelecidas novas categorias de análise, desta vez mais específicas, baseadas nos conteúdos que emergem dos discursos dos autores. As categorias foram reorganizadas de modo a dar correspondência aos temas que elas englobam e são apresentadas a seguir:

Organização dos serviços de saúde pública para o atendimento do paciente com HIV/AIDS. Incluem-se os temas: relação médico-paciente, assistência psicológica, equipe multiprofissional, o adoecer e o morrer, o paciente terminal, preconceito e discriminação contra homossexualidade, uso de drogas e HIV/AIDS.

Impacto do diagnóstico. Incluem-se os temas: a comunicação do diagnóstico, identidade, angústia e desamparo e sentimento de culpa.

O atendimento psicanalítico. Incluem-se os temas: critérios de analisibilidade ou possibilidades de escuta do portador do HIV/AIDS, luto e melancolia, ressignificação da vida e dinâmica psíquica do indivíduo acometido pela doença.

Reflexões teóricas frente à epidemia. Incluem-se os temas: abordagem 
psicossomática ou psicossomática psicanalítica, psicoimunologia, desenvolvimentos psicanalíticos, e o impacto do uso do instrumental do plano individual para o plano coletivo.

Pretendeu-se que o conjunto de categorias analisado possibilitasse respostas às questões colocadas na "Introdução" e "Objetivos" e que sua interpretação conduzisse a conclusões que pudessem contribuir para a compreensão do problema.

Foi utilizada a noção de tema enquanto “... unidade de significação que se liberta naturalmente de um texto analisado segundo certos critérios relativos à teoria que serve de guia à leitura" (BARDIN 1995, p.105). Através desse tipo de análise, se vislumbra os "núcleos de sentido" (destaque da autora) do texto - levando em conta os objetivos do estudo — “... e os temas-eixo em redor dos quais o discurso se organiza" (p.106). Dada a complexidade do material, em um mesmo texto pôde-se encontrar, muitas vezes, mais de uma vertente e/ou unidade de significação e, assim, novas possibilidades de trabalho com os dados foram se configurando no decorrer de sua análise, tomando-se o cuidado para não ultrapassar os limites da proposta.

Como já foi dito, o que permitiu a colocação dos temas em categorias foi a parte que cada um tinha em comum com os outros.

Essa aproximação aos dados assemelha-se ao trabalho do bricoleur, adotada por DENZIN e LINCOLN (1997) para se referir às metodologias da pesquisa qualitativa. O bricoleur é aquele que provê soluções para um problema na situação concreta, juntando pedaços, dando um formato organizado para eles, construindo (e desconstruindo), através dos métodos e técnicas, novas formas de montagem. AYRES (1995b) usa o termo "desmonte" teórico para esse tipo de aproximação ao material de estudo (no seu caso, a epidemiologia). Em se tratando do fato humano e da produção do conhecimento a seu respeito, essa idéia parece útil e contempla a escolha de uma forma de reflexão que busca significados e associações entre uma forma de pensar e outra (um texto e outro), sempre tendo em vista a contextualização da qual as questões de pesquisa emergem e dependem.

Enfim, sinaliza-se o quanto será complicado o caminho da análise dos textos de autores que se preocuparam com a questão da aids no Brasil no campo da saúde pública, com a parceria do referencial teórico da psicanálise, objeto do presente estudo. Complicado, mas não decepcionante. Talvez fecundo, já que se tratam de 
pesquisadores que, com pioneirismo, ousaram se lançar no campo da interpretação da epidemia, com os recursos oferecidos pela psicanálise, ainda pouco experimentada no campo da saúde pública.Em função dessas reflexões, associações e necessidade de estabelecer uma linha de raciocínio, alguns trabalhos foram escolhidos para compor o texto final do presente estudo, por serem mais significativos e ir ao encontro do interesse que fundamentou a pesquisa, numa espécie de fusão de horizontes gadameriana. O conhecimento dos mesmos pelo leitor se dará no decorrer das citações e referências. Os demais se encontram na ficha catalográfica, em anexo, para livre consulta. A seguir são expostos os achados, procurando-se encaixá-los numa seqüência que permite ao leitor sua melhor visualização. 


\section{CONSIDERAÇÕES ÉTICAS}

A pesquisa foi realizada a partir de dados secundários, sendo de domínio público a identificação dos autores envolvidos. Intentou-se preservar o anonimato das informações a respeito dos sujeitos tratados nas publicações, resguardando-se as críticas às falhas éticas que porventura foram observadas nos relatos e comunicações, por não serem essas objetos deste estudo. 


\section{RESULTADOS E DISCUSSÃO}

Neste capítulo são apresentados os produtos da literatura brasileira no campo da psicanálise, a partir do trabalho de pesquisadores que se interessaram pela aids, problema da saúde pública de grandes proporções epidêmicas que perpassa e ultrapassa o limite da relação dual analista-analisando. Torna-se possível conhecer agora quem, quando, onde e de que maneira desenvolveu sua investigação, e quais foram os progressos em direção à compreensão do fenômeno no referido campo.

\subsection{A Delimitação do Material}

Será analisada, a princípio, a composição do material coletado segundo as categorias estabelecidas, para se ter idéia do seu conjunto, caracterizando-o de forma mais objetiva quanto a alguns aspectos. Posteriormente, serão aprofundados alguns pontos na análise do conteúdo, necessários para se obter uma compreensão das questões enunciadas nos "Objetivos" deste estudo. Olha-se primeiro para o todo, para depois se olhar para as partes que o compõe, ou melhor dizendo, direciona-se o foco "de fora para dentro".

Assim, tomando-se como ponto de partida o conjunto das publicações, os textos analisados totalizaram 50, como já referido no capítulo anterior, distribuindose da seguinte forma: 22 artigos, 13 capítulos de livro, 5 comunicações em eventos, 4 teses, 4 dissertações, 1 trabalho de conclusão de curso (graduação) e 1 livro.

A Pontifícia Universidade Católica de São Paulo contribuiu com três dissertações de mestrado e duas teses de doutorado, sendo todas na área de Psicologia Clínica. Da Universidade de São Paulo obtiveram-se uma dissertação e uma tese, sendo a primeira na área de Psicologia Social e do Trabalho, e a segunda em Psicologia Clínica. A Universidade Estadual de Campinas contribuiu com uma tese de doutorado da Faculdade de Ciências Médicas.

Observando-se a seqüência temporal verifica-se como a produção brasileira sobre os temas psicanálise e aids foi sendo construída, inicialmente de forma tímida, com um texto a cada ano (de 1987 a 1989), tendo a maior concentração de 
publicações nos anos 1992, com 9 textos e 1997, com 10 textos. Não foi observada uma regularidade na produção.

Nos primeiros anos, os textos publicados no Brasil foram sendo produzidos com um sentido de dar conta da angústia dos profissionais frente à doença emergente, e para socializar as experiências de utilização de um instrumental que pudesse se adequar à gama de sentimentos provocados pela aids, chamada de catástrofe por um psicanalista inglês (HILDEBRAND 1993) ${ }^{*}$.

Os trabalhos do final da década de 80 e do início de 90 evidenciam um interesse em reorganizar os serviços de atendimento, especialmente os ambulatórios de moléstias infecto-contagiosas, local de maior concentração dos casos de aids de então. A preocupação primordial era, portanto, com o enfrentamento da doença, do doente terminal, do preconceito e discriminação dos pacientes e do medo do contágio vivenciados pela própria equipe médico-hospitalar, uma vez que as formas de transmissão não estavam totalmente assimiladas pelos profissionais e a população em geral. Buscava-se dar uma racionalidade às condições de trabalho que desse suporte para as atitudes, até certo ponto irracionais de alguns profissionais, que permeavam o ambiente de trabalho (COSTA LIMA e MELLO FILHO 1989, CASSORLA 1991).

Há trabalhos que tem um caráter de desabafo não só da angústia, mas também da indignação, atentando para que os profissionais de saúde lidem com as próprias dificuldades pessoais, antes de se aventurarem a cuidar de seus semelhantes (CASSORLA 1991). E falam bastante da morte, da dificuldade de entrar em contato com a sua representação (CALEIRO COSTA 1991, MAUTNER 1992), da homossexualidade, da promiscuidade e do estigma (COSTA e MELLO FILHO, 1987, 1988; COSTA 1992; BIRMAN 1994; FERREIRA, 1994, dentre outros).

\footnotetext{
* Esse autor, também invadido pela gama de sentimentos decorrentes do atendimento psicanalítico de uma pessoa desde os primeiros sinais e sintomas da aids até a sua morte, relata sua experiência de forma a poder compartilhá-la e dar-lhe uma significação. Expressa a idéia de que o HIV e suas seqüelas representam na cultura uma grande mudança tanto para os pacientes como para os analistas. Aponta para a possibilidade de se restabelecer a mesma relação analítica estabelecida dentro do setting, em uma outra situação "menos apropriada" como, por exemplo, a enfermaria de um hospital, ou a residência do paciente. As circunstâncias desfavoráveis do atendimento serão superadas, segundo o autor, pela seriedade do trabalho do terapeuta e do paciente. Na sua opinião, a atenção do analista deve estar voltada para a contratransferência neste tipo de trabalho, pois os “... pacientes com HIV (...) desafiam tanto nossos valores quanto nossa Ética .... Eles nos forçam a fazer uma releitura das nossas teorias sobre perversões sexuais..." (HILDEBRAND 1993, p. 74). As reflexões trazidas por esse autor são bastante consistentes com os trabalhos que serão analisados no presente estudo.
} 
Os primeiros textos produzidos foram no formato de artigos, publicados em periódicos especializados em psiquiatria e psicanálise, alguns editados pela própria instituição universitária ligada ao serviço de atendimento aos casos de aids. Alguns periódicos adotaram a estratégia de publicação temática, evidenciada a partir de 1993, havendo números dedicados especialmente ao tema da aids, suas vertentes e enfoques. Nesse sentido, pôde-se contar com os periódicos: Revista de Psicologia Hospitalar do Hospital das Clínicas de São Paulo, 1993; 3(1); Boletim de Novidades Pulsional, 1995; 80; Revista USP, 1997; 33, intitulado Dossiê Aids, e Correio da APPOA (Associação Psicanalítica de Porto Alegre), 1998; 63.

Os capítulos de livro, publicados já no início dos anos 90, foram oriundos de livros temáticos sobre aids, escritos em parceria pelos profissionais, abordando várias áreas de atuação e enfoque sobre a aids — dentre as quais, a psicanálise. Esses textos resultaram da união das pessoas que lidavam com os soropositivos ou doentes de aids, ou que militavam em prol da diminuição do estigma, preconceito, discriminação e medo, e da luta pela adoção de medidas preventivas através da implementação de políticas de saúde, visando o controle da epidemia. São exemplos dessas iniciativas os livros de CASSORLA (coord.) 1991, MELLO FILHO e col. 1992 e PAIVA (org.) 1992. Um único livro foi escrito por um só autor e versa inteiramente sobre o tema da aids e psicanálise. A autora colheu depoimentos através de entrevistas em profundidade com pessoas vivendo com HIV/AIDS e, em seguida analisou-as usando o referencial psicanalítico. Esse texto, de autoria de SANCHES, data de 1997. Parte de seu material empírico foi utilizado para desenvolver a tese que fecha o levantamento bibliográfico do presente estudo (SANCHES 2000).

Os dois primeiros textos acadêmicos datam de 1992, um tratando da questão dos doentes homossexuais (FERREIRA 1992), o outro, da drogadição (KLOURI 1992). O terceiro trabalho acadêmico, publicado em 1993, tratou da questão da morte. Todos esses temas eram palavras de ordem naquele momento.

A primeira tese analisada gerou um livro do qual se extraíram dois capítulos incluídos no presente estudo (FERREIRA 1994a e 1994b) e, a partir de uma dissertação, se escreveu um artigo (KLOURI 1993). É interessante constatar que esse tipo de procedimento é usual na academia, explorando ao máximo (no bom sentido) a mesma experiência através dos diversos desenvolvimentos teóricos que ela 
possibilita.

Permite-se, assim, na análise, transitar de um texto a outro, mas também, seguir a linha de pensamento de um mesmo autor, em mais de um texto, sobre o mesmo objeto de estudo. Com isso é possível averiguar se houve mudança do referencial teórico ou da linha de pesquisa para abordar o fenômeno.

Os textos obtidos a partir de comunicações em eventos advieram de dois encontros: um para debater os temas psicanálise e aids, aliando um Centro de Atendimento a Portadores do HIV/AIDS (Centro Corsini de Campinas) e uma Escola de Psicanálise (Escola Lacaniana de Psicanálise de Campinas), fortalecendo uma parceria; e o outro, para, em nome da ética e da solidariedade, angariar fundos para custear os medicamentos de um profissional doente de aids. Naquele momento, os medicamentos antiretrovirais ainda não estavam disponíveis na rede pública de saúde de forma universal. Esse evento, como o outro, reuniu duas instituições (Instituto Sedes Sapientiae e Núcleo de Estudos e Pesquisa da Subjetividade da PUC-SP), ambas interessadas no estudo e desenvolvimento da psicanálise, e teve a sua publicação no periódico de uma delas (Cadernos de Subjetividade - PUC SP).

Quanto aos lugares de origem, observa-se que uma grande proporção dos profissionais desenvolveu seus estudos em instituições públicas, tais como: ambulatórios, hospitais e serviços especializados em HIV/AIDS, envolvendo os sujeitos que freqüentavam esses locais para receberem atendimento clínico. Há trabalhos desenvolvidos a partir do consultório privado, seja pelo atendimento dos indivíduos soropositivos para o HIV ou doentes de aids, seja por reflexões teóricas originárias da experiência clínica em psicanálise. Existe uma produção expressiva de textos a partir do atendimento das pessoas vivendo com HIV/AIDS nesses locais e em instituições filantrópicas, sugerindo que os autores pesquisados se preocuparam não só em produzir conhecimento, mas talvez, principalmente, em diminuir o sofrimento psíquico dos pacientes. Em alguns trabalhos as instituições envolvidas não foram explicitadas.

As linhas teóricas no campo da psicanálise adotadas pelos autores para abordar os problemas foram diversas. De maneira geral, os autores utilizaram mais de uma abordagem teórica (em 25 textos isso ocorreu), embora essas não se refiram, necessariamente, às escolas psicanalíticas clássicas. 
Uma pequena digressão será feita, neste ponto, para introduzir algumas informações sobre as correntes dentro da psicanálise.

MEZAN (1985) reconhece as escolas de psicanálise como sendo a freudiana, a kleiniana, a lacaniana e a psicologia do ego. O autor considera que os kleinianos continuam a perspectiva de FREUD, enquanto que os lacanianos a recuperam e que, no dizer dos americanos da psicologia do ego, eles superam a teoria freudiana (destaques do autor).

ROUDINESCO (2000), que se interessa pela genealogia da psicanálise, enumera seis escolas de psicanálise denominadas de: annafreudismo, kleinismo, ego psychology, independentes, self psychology, e lacanismo. Todas as escolas utilizamse do método clínico baseado na fala, e na teoria fundadora de FREUD que é apoiada no inconsciente, na sexualidade e na transferência. A despeito desses aspectos comuns, existem diferenças fundamentais entre elas, que não cabem detalhar aqui, fazendo-se somente uma explanação mais geral. A composição de cada escola em termos de seus expoentes dependeu não só do solo epistemológico formado pelos seus conceitos e reformulações, bem como suas diferenças da teoria freudiana original, mas também das regiões onde elas se estabeleceram (os países).

O próprio FREUD reformulava seus conceitos à medida que a clínica assim o sugeria. Manteve como estruturante do psiquismo o Édipo, com a sua triangulação pai, mãe, filho, dando ao pai o lugar central no modelo de Totem e tabu (1912), mas já em declínio pelo seu assassinato coletivo.

Melanie KLEIN, na Inglaterra, introduz a análise de crianças precocemente, antes dos quatro anos de idade preconizados por Anna FREUD, criando o modelo pré-edipiano, e atribuindo à figura materna um lugar central. Seu seguidor mais ilustre é Donald W. WINNICOTT. A cisão na escola inglesa ocorre em função da divergência conceitual dessas duas psicanalistas e seus partidários, dando origem ao kleinismo, annafreudismo e independentes (esses últimos não nomeados no inventário feito por ROUDINESCO 2000).

Nos Estados Unidos desenvolveu-se a psicologia do ego ou ego psychology, através dos imigrantes europeus, como LOWENSTEIN e HARTMANN, e a psicologia do self. A melhor elaboração dessa última corrente é devida a Heinz KOHUT, segundo ROUDINESCO (op.cit.), americano de origem vienense, que 
priorizava o mito de Narciso ao invés do de Édipo, através do qual ele explicava as formas de mal-estar na civilização. De acordo com essa corrente, o indivíduo voltase cada vez mais para si mesmo, havendo muita dificuldade na relação com o outro por causa de uma falta de afeto materno fundante. É uma visão adaptada ao espírito americano e, em decorrência disso, considerada pragmática.

LACAN, na França, baseado nos princípios da lingüística de SAUSSURE, abandona o substrato biológico do inconsciente freudiano e passa a considerar a linguagem como a base da sua existência. Elaborou a tópica composta pelas noções de simbólico, imaginário e real, e a teoria da nomeação. Desloca o pai do lugar central, dando o seu poderio à mulher, declinando então, a função paterna.

Em se tratando do solo brasileiro, ROUDINESCO (2000) reflete que a inserção da psicanálise nas universidades favoreceu a manutenção de uma base mais freudiana, a despeito da instituição psicanalítica oficial, a IPA (International Psychoanalytical Association) seguir outra linha teórica eminentemente inglesa (com KLEIN, BION e, mais recentemente, WINNICOTT).

No presente estudo, os resultados obtidos mostram-se concordantes com essa posição. Como já foi dito acima, a psicanálise praticada na academia contribuiu muito para o estudo da epidemia da aids. Além disso, o autor mais citado nos textos foi FREUD em 33 trabalhos, seguido de LACAN (11), WINNICOTT (7) e Melanie KLEIN (5). Vários outros autores foram abordados em um número menor, sendo interessante observar que psicanalistas brasileiros tem sido citados por estarem, também, construindo teorizações e desenvolvendo trabalhos úteis ao campo. São eles: Jurandir Freire COSTA, Joel BIRMAN e Fábio HERRMANN. No caso desse último autor, verificou-se que ele orientou um dos trabalhos acadêmicos incluídos no presente estudo (CAVALLARI 1997) e foi referencial de análise para outros dois (CIPRIANO 1999 e RUIZ 1999).

Vários autores utilizaram um único enfoque teórico (21) e 4 autores não explicitaram o referencial utilizado, mas trabalharam com conceitos do campo psicanalítico, através dos quais deixam implícitas suas preferências.

Passando para um outro aspecto da análise, a natureza dos textos, notam-se as suas diversidades. As publicações que visavam compartilhar com os leitores a experiência de atendimento dos portadores do HIV e doentes de aids foram 
denominadas relatos e reflexões sobre a experiência. Foram 12 textos. Alguns autores procuraram fazer uma reflexão teórica sobre o tema, tomando a aids como centro de interesse e como fenômeno passível de ser compreendido pelas noções da psicanálise. A principal preocupação foi com a doença em si e suas implicações para o campo da saúde. Foram 20 textos. Houveram autores que elaboraram uma espécie de reflexão metapsicológica sobre a aids, tomando a concepção psicanalítica como prioridade e inserindo a questão da aids nela, como algo da ordem do sinal dos tempos para onde a psicanálise pudesse voltar o seu olhar. Esse movimento é oposto ao anterior: toma a psicanálise como centro de interesse e a aids é o exemplo utilizado para a aplicação do conhecimento psicanalítico. Foram 5 textos. Finalmente, alguns trabalhos (13) foram resultado de pesquisa empírica, em que se partiu de uma questão de interesse, formulou-se uma hipótese, um projeto de pesquisa e, a partir dos dados coletados, chegou-se a considerações e conclusões sobre o tema de estudo. Esse último grupo foi formado basicamente pelos estudos da academia e seus derivados. 


\subsection{O Conteúdo dos Textos}

Saindo do campo mais fronteiriço e adentrando mais na análise de conteúdo, é possível conhecer quais os pressupostos utilizados pelos autores nas produções, objetivando descobrir e evidenciar as conexões entre elas e o universo de significações construído a partir desses trabalhos. Para isso faz-se necessária a criação de outras categorias analíticas, apoiadas na investigação do material e na metodologia adotada. A título de mapear as unidades de significação identificadas e possibilitar a melhor visualização e compreensão dos temas e seus referentes foi construído o quadro abaixo, do qual dependem as articulações entre os textos e onde suas interfaces se sobressaem.

Caberiam outras formas de categorização diferentes desta, porém a opção feita tem o propósito de organizar o material de acordo com os objetivos do presente estudo de sistematizar o que se encontrou e estabelecer o estado da arte no campo, para, a partir daí, dar outros passos na direção do controle da epidemia em termos da prevenção de novas infecções e da melhoria da qualidade de vida das pessoas vivendo com o HIV/AIDS. 
Textos analisados segundo temas e categorias de análise.

\begin{tabular}{|c|c|c|}
\hline CATEGORIAS & TEMAS & TEXTOS \\
\hline \multirow{5}{*}{$\begin{array}{c}\text { Organização dos serviços de } \\
\text { saúde pública para o } \\
\text { atendimento do paciente } \\
\text { com HIV/AIDS }\end{array}$} & Relação médico-paciente & $\begin{array}{c}1,2,3,8,12,13,22, \\
38\end{array}$ \\
\hline & Assistência psicológica & $\begin{array}{c}1,2,3,8,14,16,22, \\
26\end{array}$ \\
\hline & Equipe multiprofissional & $\begin{array}{c}1,2,3,5,8,12,13 \\
14,26,44,48\end{array}$ \\
\hline & $\begin{array}{c}\text { Doença. Morte. Paciente } \\
\text { terminal }\end{array}$ & $1,5,11,12,13,39$ \\
\hline & $\begin{array}{l}\text { Preconceito e discriminação } \\
\text { contra homossexualidade, uso } \\
\text { de drogas e HIV/AIDS }\end{array}$ & $4,5,12,38,39$ \\
\hline \multirow{4}{*}{ Impacto do diagnóstico } & Comunicação do diagnóstico & $8,30,37,38,40$ \\
\hline & Angústia e desamparo & $1,9,22,30,44,48$ \\
\hline & Sentimento de culpa & $22,23,37,39,43$ \\
\hline & Identidade & $\begin{array}{c}10,16,22,30,32, \\
37,47,49\end{array}$ \\
\hline \multirow{4}{*}{ Atendimento psicanalítico } & $\begin{array}{c}\text { Critérios de análise } \\
\text { Possibilidade de escuta do } \\
\text { portador do HIV/AIDS }\end{array}$ & $25,27,34,41,43$ \\
\hline & Luto e melancolia & $8,9,23,34,39,43$ \\
\hline & Ressignificação da vida & $\begin{array}{c}9,10,22,23,29,35, \\
37,38,47,50\end{array}$ \\
\hline & Dinâmica psíquica & $\begin{array}{c}6,9,10,13,17,18 \\
20,23,29,34,37 \\
40,41,43,44,47 \\
48,49,50 \\
\end{array}$ \\
\hline \multirow{4}{*}{$\begin{array}{c}\text { Reflexões teóricas frente à } \\
\text { epidemia }\end{array}$} & $\begin{array}{c}\text { Abordagem psicossomática } \\
\text { ou psicossomática } \\
\text { psicanalítica. }\end{array}$ & $15,43,45,50$ \\
\hline & Psicoimunologia & $1,3,24$ \\
\hline & $\begin{array}{l}\text { Desenvolvimentos } \\
\text { psicanalíticos }\end{array}$ & $\begin{array}{c}4,6,7,9,19,21,27, \\
28,32,33,35,36, \\
42,45,46\end{array}$ \\
\hline & $\begin{array}{l}\text { Impacto do uso do } \\
\text { instrumental do plano } \\
\text { individual para o plano } \\
\text { coletivo } \\
\end{array}$ & $31,32,36,50$ \\
\hline
\end{tabular}




\subsubsection{Organização de Serviços de Saúde Pública para o Atendimento do Paciente com HIV/AIDS}

O texto número um nesta história de parceria entre a psicanálise e a aids no Brasil foi publicado em 1987, como já se disse, e trata da "Assistência psicológica ao paciente de aids" (COSTA e MELLO FILHO 1987). Ele compõe, juntamente com outros, um grupo de trabalhos que refletem a preocupação de seus autores em fazer frente à demanda que chegava às instituições para o atendimento naquele momento.

Sob a denominação de Organização de serviços de saúde pública para o atendimento do paciente com HIV/AIDS incluem-se as vicissitudes do atendimento, desde a relação médico-paciente e, evidentemente, de outros membros da equipe com o paciente, além do próprio relacionamento interpessoal da equipe. Estão incluídos também o preconceito, a discriminação contra o paciente com HIV/AIDS, o medo da infecção, a desinformação sobre a doença e suas formas de contágio. É necessário não deixar de mencionar a dificuldade e o medo que todo ser humano tem ao se deparar com o adoecimento incapacitante e a morte que estes pacientes estampavam e os profissionais convertiam em ato. Isso equivale a dizer que os profissionais nem sempre podiam expressar com palavras seus sentimentos, e esses eram convertidos em ações agressivas ou de ataque dirigidas aos pacientes, mesmo que de forma camuflada.

Nas falas dos autores evidencia-se a necessidade de contribuir para a compreensão e superação dos problemas trazidos pela aids na figura de suas vítimas, porém, mais do que isso, a indagação sobre a própria impotência e sobre a melhor forma de intervir. Como profissionais de saúde, esperavam poder minimizar o medo e o preconceito da sociedade e dos próprios colegas de trabalho, visando o acolhimento do paciente, do seu sofrimento para melhorar, com isso, a sua qualidade de vida. Daí a mobilização dos autores para tirar a aids do lugar de doença do outro e não doença minha, mantido pelas funções identificadas por Herbert DANIEL na sociedade em que o cidadão está imerso: a função anestésica, cuja finalidade é o esvaziamento da consciência do problema social, e a função camufladora que serve para atribuir ao enigma e ao mistério os problemas sociais e humanos concretos (DANIEL citado por CALEIRO COSTA 1992). Nesse aspecto, o papel de decifrador 
exercido pelo psicanalista tem uma grande importância, pois, pelo menos, começa-se a fazer uso da palavra, seu instrumento primordial de trabalho. É por meio dela que se pode traduzir o que está incompreendido sob esse tipo de funcionamento social (nos laços sociais em geral e no interior das equipes de saúde).

Sob o olhar de um supervisor de equipe de saúde multiprofissional que lida com o paciente de aids e os soropositivos, uma experiência é descrita utilizando conceitos da teoria psicanalítica para compreender os mecanismos envolvidos e as emoções despertadas nesses profissionais (CASSORLA 1991). Abordando conceitos como a negação, rêverie (BION) ou continência, transferência, contratransferência, identificação, idealização, narcisismo, atuação, sentimento de culpa e masoquismo, o autor reflete sobre o que a experiência lhe proporcionou.

CASSORLA (1991) constata, ainda, que as diferenças vivenciadas no trabalho com aids em relação a outros atendimentos levam o profissional a: defrontar-se com aspectos específicos como o medo da infecção e o medo de que outros saibam que ele lida com aids; manusear uma grande quantidade de informações (científicas ou não) sobre a doença; enfrentar as dificuldades de lidar com homossexuais, toxicômanos, prostitutas, etc, e com a imprevisibilidade do diagnóstico e prognóstico; trabalhar com pacientes jovens no auge de sua força vital, tendo que se haver com a morte e o morrer dessa clientela. Todas essas vivências levam o profissional a refletir sobre sua própria morte, sendo praticamente inevitável sentir impotência e desesperança, e usar a agressividade, a negação, a atuação e toda a gama de mecanismos mentais que o invadem para se defender. Como se não bastassem todas essas dificuldades, o profissional tem ainda que se deparar com os problemas sociais decorrentes do diagnóstico HIV positivo que trazem em seu bojo a dimensão coletiva da saúde, aspecto nem sempre levado em conta no atendimento médico individual.

Diante desse quadro, CASSORLA (1991) considera ideal que a equipe aproveite todas as experiências que vivencia para o seu próprio desenvolvimento, incluindo as formas de ver a vida e a sabedoria no viver. Enfatiza a necessidade de um vínculo forte de confiança e acolhimento ao paciente, pois esse, muitas vezes, só o recebe da equipe de saúde e de mais ninguém, através da continência ou sustentação do mesmo. As reações primitivas do paciente poderão surgir através da 
transferência em relação ao profissional de saúde e as reações desse último (contratransferência) dependerão de como ele lidou com seus próprios aspectos passados e de como esses internalizaram-se em seu mundo interno. Os mecanismos de identificação e idealização podem se fazer presentes, bem como as características narcísicas, a insegurança e a incapacidade de pensar provocada pelas circunstâncias do atendimento. Tudo isso pode levar o profissional à atuação (acting out: atos do profissional que são iatrogênicos ou danosos à relação terapêutica, sob a ação de mecanismos inconscientes), ao sentimento de culpa, às atitudes de masoquismo, etc.

SANCHES (1997b) compartilha da opinião de CASSORLA e enfatiza a necessidade de troca de experiências entre os profissionais que trabalham com aids, favorecendo o manejo das angústias. Um suporte poderia ser dado pela presença de um supervisor, alguém distanciado da rotina do serviço de saúde que enriqueceria o trabalho do profissional e daria mais qualidade ao atendimento dos pacientes. Portanto, sob a ótica do profissional, a disponibilização desse espaço é fundamental para a exposição e elaboração dos sentimentos que emergem de um processo intersubjetivo sofrido, mas também, muito rico, como descrevem os autores que são apresentados a seguir.

SOUZA (1992) analisa a contribuição da psicanálise ao campo dinâmico da relação profissionais de saúde-paciente no contexto de um hospital geral. O grupo de reflexão multiprofissional baseado no referencial teórico de BALINT, BLEGER, LUCHINA, BION, que são abordagens psicanalíticas do dispositivo grupal, contribuiu para o aumento do conhecimento dos profissionais e, através das trocas, possibilitou a elaboração dos conflitos emergentes da tarefa assistencial a pacientes com aids, bem como das relações conflitivas entre os diferentes profissionais que integram a equipe de saúde. Isso só foi possível graças à produção de significações que este tipo de estratégia interpretativa favorece, por meio da qual se estabelece uma maior integração nas trocas simbólicas do grupo multiprofissional. A autora considera que existe uma intensificação de conflitos decorrente da aids, na assimetria da relação médico-paciente. Esses conflitos têm implicações no tratamento individual, mas evidenciam também a oposição entre o individual e o coletivo, ressaltando as contradições deste último, pois a coletividade que discrimina é a mesma que tem que criar as condições para o atendimento terapêutico (a equipe 
multiprofissional). É um desafio para o conhecimento médico que tem que dar conta também da dimensão existencial do atendimento.

No enfrentamento desses conflitos, das dificuldades com o uso do instrumental proposto e da intencionalidade e interesse do profissional que opta pelo atendimento desta clientela, é possível o crescimento como ser humano e o desenvolvimento do saber tecnocientífico, tanto de um (o paciente), como de outro (o profissional).

COSTA e MELLO FILHO (1989) consideram a experiência de acompanhamento de um paciente até a sua morte como uma das mais completas que um profissional de saúde pode ter. Ela envolve dignidade, aprendizado e vida. A morte, sem apenas destruir e consumir pode também fertilizar a vida. A experiência, vivida na plenitude pelo profissional e pela equipe, pode ser “... fator de agregação, solidariedade e de crescimento, diante da possibilidade de lidar com as situações limítrofes da existência humana" (p.25).

Em outro trabalho, MELLO FILHO (1992) relata algumas reflexões importantes sobre o morrer e uma delas é a de que “... neste período terminal ninguém melhor do que o próprio paciente para servir de bússola para indicar a melhor forma de ajudá-lo, devendo ser respeitado em suas defesas e possibilidades. [Para isso, é necessária] (...) uma comunhão de mentes que nos permita penetrar nos abismos psíquicos onde se aloja o fantasma da morte dentro de cada um de nós. É destas profundezas do existir que iremos retirar a sapiência, a lucidez e o senso de realidade que irão nos ajudar neste trabalho" (MELLO FILHO 1992, p.311).

Percebe-se uma espécie de superação da impotência que o médico sente pelo não saber provocado pela aids - uma doença nova naquele momento — obtida da própria relação com o paciente que ensina, bastando que as resistências e entraves do profissional sejam vencidos, e os seus conteúdos subjetivos discriminados. O profissional deve perceber também suas próprias fantasias e representações, seus valores e preconceitos. Identificando os sentimentos ambivalentes e a ansiedade frente à questão da morte, aos limites e impotência de sua ação (quebra do ideal de cura e de poder do ato médico), ao medo do contágio, aos valores a respeito da sexualidade, etc., estará mais preparado para lidar com os próprios conflitos, diminuindo o nível de ansiedade paralisador e desestruturante. Objetiva-se, dessa forma, vencer o conflito (ou a ambivalência) entre o prestígio institucional e a 
impotência terapêutica e se embrenhar na vivência do desafio profissional (SOUZA 1992, DIAS 1993).

Segundo os discursos dos profissionais, a assistência psicológica, num primeiro momento, deve possibilitar escuta e continência para as vivências do paciente (extensiva aos seus familiares e parceiros) de forma que the permitam discriminar, nomear e elaborar suas angústias e fantasias, além de identificar a maneira individual pela qual seu mundo mental reage à nova realidade de ser soropositivo.

Para DIAS (1993) o psicólogo na instituição hospitalar não deve “... ocupar o lugar de quem pode obliterar a ruptura e as feridas provocadas pela aids, o lugar ilusório do profissional encarregado da angústia (...) sua possibilidade de sobrevivência reside exatamente em escapar a essa armadilha criada pelo desejo de quem oferece escuta e na possibilidade de NOMEAR, de transformar em palavras o que é vivido por todos os personagens envolvidos neste campo" (p.13) (destaque da autora).

Essa fala de DIAS (1993) soa como muito semelhante à de PESSOA LABAKI $(1998,1999)$ que usa o conceito de desamparo para definir o sentimento de medo da perda do amor do Outro que a aids desencadeia no paciente e que o terapeuta, o membro da equipe que vai ouvi-lo, vai identificar e suportar. O caso que utiliza para ilustrar seu discurso condiz com a imagem que o restante da equipe tem deste profissional (como relatado acima), uma vez que, no atendimento citado, foi muito difícil não só o primeiro contato com a paciente, como também o estabelecimento do vínculo e do diálogo através da palavra propriamente dita. A dinâmica que se cria na instituição, quando o atendimento foge das modalidades costumeiras, apresenta um excedente de descontrole e ansiedade, gerando um desconforto e uma suspeita referente à competência do profissional.

Todos esses autores, anteriormente intitulados de pioneiros no presente estudo, são também corajosos, na medida em que estão expondo suas práticas nem sempre coroadas de êxito, deixando transparecer suas feridas e fragilidades em nome do compartilhamento do saber (e do não-saber) com a comunidade científica, dando suas contribuições para a construção de conhecimento neste campo. E parece ser exatamente nessa expressão da angústia, através da palavra escrita, que se processa a resolução dos conflitos e a elaboração dos desejos e anseios inerentes ao cuidado de 
outros semelhantes.

Adotando agora o prisma do paciente na relação com o profissional que o atende, os trabalhos que enfocam diretamente esse tema e baseiam-se no relato dos próprios pacientes são os de SANCHES (1997a e 1997b).

A autora abordou vários aspectos nas entrevistas que realizou, revelando os sentimentos dos pacientes desde o seu diagnóstico de soropositivos para o HIV. O resultado positivo, tema que será detalhado mais à frente, decodificado como uma consideração à exclusão, à degradação e à morte num primeiro momento, ameaça desabar o mundo do sujeito. A autora afirma que ele só não desaba, pois há o outro que é capaz de ressignificar a situação (o médico ou outro profissional de saúde). Decorre daí a importância — já assinalada por CASSORLA (1992) — do interesse, desenvolvimento e preparo do profissional para lidar com esse tipo de situação de trabalho (que pode ser em um contexto terapêutico ou de aconselhamento sorológico).

SANCHES teve a oportunidade de ouvir os depoimentos de dois pacientes a respeito do mesmo profissional e constatou a diferença de sua postura frente aos mesmos. Diante do paciente homossexual, o profissional adotou uma postura "objetiva" e distante que foi vivida como um violento ataque pelo paciente, e mostrou-se extremamente continente e sensível quando lidou com uma paciente não pertencente aos "grupos de risco" socialmente estigmatizados. "É muito difícil evitar que os preconceitos, baseados em pré-conceitos culturalmente estabelecidos, aliados a questões pessoais de cada profissional afetem a relação. São questões geralmente não-conscientes para os envolvidos que, exatamente por isso têm uma ação mais intensa e profunda" (SANCHES 1997b, p.51) (destaques da autora). Isto pode ser evitado através da tomada de consciência destes aspectos.

A autora sugere que o serviço de saúde esteja preparado para receber o paciente desde a sala de espera, atentando para que o inquérito ao qual ele é submetido seja feito com tato. É aconselhável que o profissional tente se colocar no lugar do paciente e controle a curiosidade que, às vezes, tem mais a ver com suas fantasias do que com a realidade do paciente.

SANCHES (1997b) aponta que o AZT muitas vezes é prescrito pela impotência desencadeada pela aids. Isso foi evidenciado nos depoimentos que a autora ouviu, 
nos quais a prescrição do remédio era associada à piora do quadro clínico. Para o paciente, isso pode ser vivido como o fracasso diante da doença, havendo, segundo ela, a necessidade de avaliar adequadamente o momento de iniciar a medicação e explicar claramente os motivos para o paciente.

SANCHES (1997a) e FERREIRA (1994a) observaram, de maneira concordante com a postura de MELLO FILHO mencionada antes, a necessidade de buscar o saber na relação com o paciente, tendo-se em vista que também do lado desse existe o desejo de indagar e pesquisar sobre tratamentos alternativos para a sua doença. É uma atitude que os pacientes esperam que seus médicos aceitem. Essa aceitação melhora significativamente a relação médico-paciente, na medida em que mostra que o médico admite um outro tipo de saber (o do paciente) e lhe dá um certo poder, tirando-o da condição de impotência. Restitui-se ao paciente a responsabilidade pela sua saúde, antes delegada inteiramente ao médico que, agora, não dispõe mais da cura da doença. Há, então, uma transformação mútua da imagem internalizada que um tem do outro.

“O que o paciente procura num profissional de saúde é a esperança e o reconhecimento de que existe nele, sujeito, uma força de vida. Uma possibilidade de se fortalecer para enfrentar os ataques que virão, de dentro e de fora. Procura alguém que não tema chegar perto da dor e da angústia que carrega. Mas que não se contamine com ela a ponto de ficar paralisado (...) alguém que o respeite e ouça, para ser também ouvido. Um profissional que seja, como disse Betinho [Herbert de SOUZA], um amigo" (SANCHES 1997a, p.55) (destaque da autora). 


\subsubsection{O Impacto do Diagnóstico}

Nos meandros da relação profissional de saúde-paciente freqüentemente defronta-se com a tarefa de comunicar o resultado sorológico. Essa revelação é relatada em vários trabalhos como tendo ocasionado o impacto do diagnóstico HIV positivo, experiência sobre a qual se tratará a partir de agora.

O trabalho de CAVALLARI (1997) será privilegiado para iniciar o diálogo entre os autores, em razão de ser específico sobre o tema. A maioria dos demais textos toca em algum momento no assunto, com informações que serão utilizadas de forma a complementar a narrativa. A autora realizou entrevistas com pessoas com diagnóstico HIV positivo, indagando sobre a forma como esse lhes foi comunicado e a dinâmica psíquica que se operou em torno do mesmo. Como referencial de análise utiliza conceitos freudianos e o conceito de ruptura de campo, de Fábio HERRMANN. Esse conceito baseia-se na Teoria dos Campos, do mesmo autor, que pressupõe a existência de um campo psicanalítico que é o campo mesmo da relação humana. Toda relação comporta uma espécie de "essência metafísica da relação, é uma essência operativa, cognoscível, isolável teoricamente" (HERRMANN citado por CIPRIANO 1999, p.19). O campo ordena os significados das relações, possibilitando sua apreensão e sua própria produção. Quando o campo é rompido, isso só é percebido pela modificação da relação que evidencia o vazio da organização anterior, promovendo a reestruturação do seu sentido.

Para as pessoas entrevistadas no estudo de CAVALLARI (1997), o momento da comunicação do resultado HIV positivo foi decisivo, mudando suas vidas, desde o período que o antecedeu, vivido como angustiante, com fantasias persecutórias e associações referentes à sexualidade reprimida. O momento da comunicação do resultado foi considerado um acontecimento traumático na vida destes entrevistados e o conhecimento do diagnóstico “... provocou uma ruptura no campo organizador de seu aparato mental..." (CAVALLARI 1997, p.196), revelando emoções e desvelando aspectos inusitados. O grau de desorganização psíquica decorrente dos resultados e a possibilidade de reorganização foram diferentes a partir da história de cada sujeito.

A autora considera que a relação com o paciente soropositivo é disruptiva no sentido de fazer vir à tona aspectos do inconsciente não tocados e desconhecidos. $\mathrm{O}$ 
resultado soropositivo redimensiona o passado e o futuro a partir das possibilidades de interpretação do sujeito no presente. Os pacientes apresentam alterações no horizonte temporal ao se referirem ao momento da comunicação do teste HIV, contradizendo-se quanto às datas e ao tempo de diagnóstico, sintoma da desorganização psíquica vivida. "Pacientes que no novo campo estabelecido após o diagnóstico não puderam elaborá-lo, evidenciaram o desenvolvimento de patologias orgânicas e dificuldades em constituir novos projetos de vida" (CAVALLARI 1997, p.198). O sujeito, a partir do resultado positivo, faz uma nova interpretação sobre si mesmo, com alguma modificação da identidade, havendo a necessidade de integrar fragmentos do campo anterior ao diagnóstico. O campo ocorre sempre em relação à forma como é dado o diagnóstico ao paciente, assim como sua ruptura, motivo pelo qual se sugere um preparo do profissional que faz a comunicação.

SANCHES (1997a) no capítulo em que analisa o papel dos médicos e demais profissionais de saúde compara, através dos depoimentos, o quanto a forma de transmissão do diagnóstico ao portador foi significativa para a sua assimilação, e a continuidade de sua vida. Constatou que os pacientes, de maneira unânime, esperam que os médicos os vejam como pessoas inteiras que precisam ser ouvidas e respeitadas, e podem ter um papel ativo no tratamento e provocar mudanças. Assim, têm possibilidade de recuperar sua força de vida e enfrentar melhor os ataques que virão de dentro e de fora.

Da parte do profissional, LEMOS (1998), a partir de seu contato com o tema da aids como analista, apercebe-se de sua dificuldade em saber sobre a própria condição sorológica, desde a realização do exame até o recebimento do resultado, e relata a forma como lidou com isso. A autora tomou consciência dessa dificuldade através da subversão pelo lapso do seu próprio discurso. O desejo subjacente de não querer saber da sua condição sorológica, assim manifesto, era até então desconhecido. Esse desejo, ao ter acesso à consciência, possibilitou a ressignificação de alguns sentidos, dentre eles a posição do analista no sentido de lidar com o tornar conhecido o desconhecido dos seus analisandos e, antagonicamente, querer manter algo de si mesmo não conhecido. Na mesma perspectiva, a autora insere o outro (o parceiro) 
como objeto de desejo ${ }^{*}$, e também como risco de infecção. Num verdadeiro jogo de palavras para as quais se requer encontrar um significado, oscila-se entre pólos de “não querer saber" e de "saber e mesmo assim não querer saber", em que o sujeito (paciente e/ou analista) vê os sentimentos antagônicos se digladiarem. Segundo Lemos, o que está colocada é uma divisão entre saber e verdade. O fato de saber do próprio diagnóstico negativo não elimina no sujeito o sentimento de desconfiança na relação com o outro e esta contradição é acompanhada da recusa de querer saber da condição sorológica do parceiro, o que torna o ato sexual um ato de risco de infecção pelo HIV, pois a relação com o objeto de desejo é sempre mantida para obtenção da satisfação. É, portanto, uma relação raramente resistida.

Esse tipo de conflito apontado por LEMOS retrata como é complexo o funcionamento psíquico, especialmente no que se refere à consciência de risco dos indivíduos. Isso pode ser evidenciado a partir da própria comunicação do resultado sorológico e de seu impacto, conforme foi assinalado em alguns trabalhos. Esses aspectos ligados à consciência/percepção de risco dos indivíduos infectados estão presentes desde o momento anterior à realização do teste anti HIV e variaram conforme o gênero, papel de gênero (ligado à escolha sexual) e situação de risco. Eles remetem às práticas de prevenção e de não prevenção do HIV, à constituição da identidade e aos sentimentos (de culpabilidade ou destrutividade) associados à possibilidade de se infectar dos indivíduos.

Investigando a consciência do risco dos seus entrevistados, CAVALLARI (1997) verificou que, dentre os pacientes heterossexuais (homens e mulheres), não havia o sentimento de estarem em risco até haver um motivo para fazerem o exame. Alguns pacientes homossexuais que não se identificavam com a homossexualidade, não se viam em risco, enquanto que outros, vivenciaram a consciência da proximidade do risco como imponderável. Os conflitos relacionados à inclinação

\footnotetext{
* "Nos escritos psicanalíticos, o termo objeto encontra-se, (...) em numerosas expressões como escolha de objeto, amor de objeto, perda do objeto, relação de objeto (...). Não deve evocar a noção de coisa, de objeto inanimado [que] (...) contrapõe às noções de ser animado ou de pessoa. (...) os usos do termo objeto têm sua origem na concepção freudiana da pulsão [na qual] distingue o objeto do alvo: (...) 'o objeto da pulsão é aquilo em que ou porque a pulsão pode atingir o seu alvo'; ao mesmo tempo, o objeto é definido como meio contingente da satisfação. (...) A noção de objeto em psicanálise não deve apenas entender-se em referência à pulsão (...) ela designa igualmente aquilo que para o indivíduo é objeto de atração, objeto de amor, na generalidade dos casos uma pessoa" (LAPLANCHE e PONTALIS 1970, p. 407-9).
} 
homoerótica interferiram na utilização de medidas preventivas. As pessoas com mais preconceito perante a aids vivenciaram maior desorganização frente ao resultado positivo, pois as representações da inclinação homoerótica não estavam associadas à sua identidade e realidade. A mesma evidência foi observada por COSTA (1992), citado por ela, e igualmente analisado no presente estudo.

Esse autor expressa idéias e chega a algumas conclusões ao tratar especificamente do homossexualismo/homoerotismo a partir da elaboração de uma pesquisa com duas amostras: uma constituída de pacientes do seu consultório privado e outra, de pessoas entrevistadas em uma pesquisa antropológica. COSTA (1992) faz um estudo envolvendo as relações entre consciência da "identidade homossexual" e atitudes frente à aids. Ele considera que, ao analisar as falas ou discursos manifestos, pode-se dar conta da maneira pela qual o sujeito estrutura a imagem do eu ou a sua auto-imagem, e como isso entra em acordo com o psiquismo. $\mathrm{O}$ autor analisa as respostas dos indivíduos com inclinação homoerótica diante da aids ou do risco de infecção, e propõe uma classificação das reações desses sujeitos frente ao risco de infecção pelo HIV. Faz a ressalva da não pretensão de exaustividade desta proposta, por estar baseada na amostra estudada. As reações que ele evidenciou são as seguintes: a proteção pelo preconceito, observada nos indivíduos majoritariamente identificados com as regras da moral sexual oitocentista ${ }^{*}$ que possuíam uma série de traços comuns entre si - em sua maioria, os clientes do consultório privado; $a$ proteção contra o preconceito, observada nos indivíduos que se aproximam do modelo gay de identidade homoerótica, cujas características eram a aceitação plena da "identidade homossexual" e a revalorização dessa identidade contra o preconceito e o estigma desvalorizante que o envolve; e, por fim, a privatização moral na avaliação do risco da infecção, reação observada nos indivíduos com impossibilidade de dispor de modelos de identidade sexual publicamente discutíveis e partilháveis por outros. Por isso, estes eram os mais expostos aos riscos de infecção. Resolviam "individualmente" a questão da prevenção e constituíam a

\footnotetext{
* O autor refere-se à moral da sociedade burguesa do final do século XIX, em que a sexualidade tinha o propósito de manutenção da ordem de parentesco e dos interesses das classes, das nações, dos estados, da cultura e não da satisfação dos indivíduos. Nesse contexto, a homossexualidade era considerada como um desvio. O verbete homossexual aparece sempre destacado no texto, pois COSTA considera-o preconceituoso e decorrente da forma como a sociedade foi se constituindo marginalizando os indivíduos com escolha de objeto sexual diferente da hegemônica.
} 
maioria dos pesquisados.

$\mathrm{O}$ autor considera que possam existir outras formas de estabilização, que consiste na “... aceitação dos plenos sentimentos e modos de vida" (PLUMMER citado por COSTA 1992, p.144), da identidade homoerótica que ultrapassam os limites do universo estudado. Dentre os pesquisados, observou-se uma diferença na eficiência das atitudes de proteção diante do desafio da aids, conforme a identidade do sujeito seja constituída. Essa eficiência depende da forma como o sujeito se posiciona frente à sua "homossexualidade" (destaque do autor).

Outra especificidade de atitudes frente ao risco refere-se aos pacientes hemofílicos. Um único trabalho detectado pela presente pesquisa tratou da questão da hemofilia, sendo importante citá-lo, não pela quantidade que representa, mas pela sua especificidade (EKSTERMAN e col. 1992). De acordo com as autoras, o hemofílico já possui uma doença incurável e se percebe como pertencendo às fileiras dos que serão prováveis portadores de outra doença sem cura (dentro da concepção vigente de então, os grupos de risco). Seu "eu" é hemofílico, ele não se sente uma pessoa. A tomada de consciência de fazer parte de um "grupo de risco" para a aids faz com que já viva um "estar infectado" pelo vírus. A nova doença vem selar as deficiências e dificuldades existentes na vida do paciente, inclusive a concretude de ameaça de morte. A impressão causada pelos psicólogos nesse relato é a de que eles devem dar uma sustentação dupla (se é que ela existe) para a hemofilia e para a aids, acrescida ao fato de que muitos são crianças e adolescentes, para os quais uma revelação deste teor adquire proporções inimagináveis e imprevisíveis.

Quanto aos usuários de drogas, também incluídos nos grupos de risco daquele momento, segundo KLOURI (1992), diante do diagnóstico de aids, as reações primordiais de alguns pacientes por ela entrevistados foram de revolta, com direcionamento da pulsão de morte para os objetos, havendo deliberadamente o desejo de infectar os outros através do compartilhamento de seringas e do não uso de preservativo nas relações. Ao mesmo tempo essa destrutividade voltava-se para si mesmos, na medida em que, com esses comportamentos, poderiam se reinfectar, denotando uma ambivalência. Outros tiveram reações de preservação da vida, aproximando-se da realidade através da aderência ao tratamento médico, da preocupação com a prevenção e a saúde de forma geral. A autora levanta a hipótese 
de que isso seja resultante de um abalo na onipotência, uma característica observada por ela nestes pacientes que é exatamente o que os impede de ter consciência do risco de infecção.

Independente da categoria de exposição responsável pela infecção do paciente, os autores constataram, de forma consensual, que há um impacto provocado pela comunicação do diagnóstico e é necessário alterar o modo de dar a notícia. No momento da comunicação, as falas e atitudes dos profissionais são fundamentais para dar suporte frente ao sentimento de desamparo desencadeado e favorecer a elaboração do diagnóstico. A equipe deve compartilhar a responsabilidade desta tarefa para dar suporte aos pacientes e uns aos outros, abrindo um espaço para a manifestação dos sentimentos e temores como forma de alívio da angústia. A colaboração dos familiares e amigos também se mostrou boa coadjuvante na lida com a dor e o sofrimento decorrentes da condição de doente de aids.

PESSOA LABAKI (1996, p.159) conjetura que a aids tem uma posição singular, diferente de outras doenças incuráveis. Ela faz com que o médico não se permita o direito de excluir a morte do panorama futuro da vida de seu paciente, pois o caráter de transmissibilidade da aids obriga-o a anunciá-la ao portador do HIV. Para ele, segundo a autora, “... a qualidade de portador sadio (...) incrementa a vivência da morte como fantasma, pois no real do corpo suas marcas ficarão por longo tempo desconhecidas. Impossível de ser prevista, a morte anunciada recupera para o portador a sua dimensão humana" (destaque da autora).

Em relação ao que foi colocado sobre a morte anunciada, observam-se algumas discordâncias entre os autores. “A comunicação do diagnóstico introduz a dimensão do tempo (...) [que] não é o tempo cronológico, físico, mas é uma temporalidade no interior da sociedade, como ela simboliza isso. Porque a questão [da morte anunciada] (...) estava colocada, como se todos nós não tivéssemos uma morte anunciada... Mas isso, do ponto de vista psicanalítico, por exemplo, [em] Psicologia das massas FREUD fala exatamente do pânico. (...) ele inverte essa relação (...) não é que o pânico desintegre os laços sociais, mas, pelo contrário, a desintegração dos laços sociais é que conduz ao pânico". Pode-se conjeturar que o indivíduo vivencie

\footnotetext{
* Colocação feita pelo Prof. Dr. Raul Albino Pacheco Filho no Exame de Qualificação do presente estudo (PACHECO FILHO 1999 out 21, comunicação pessoal).
} 
esse momento da comunicação do resultado do teste anti-HIV como tão penoso, exatamente pelas conseqüências da nova condição que podem enfraquecer ou até romper os laços sociais por meio do isolamento na relação com os outros e não, propriamente, pelo enfrentamento da mortalidade que é inerente à natureza humana.

Uma outra discordância foi evidenciada por FERREIRA (1992) quanto a caracterizar a revelação e a própria doença como uma sentença de morte, uma vez que muitos portadores do vírus há muito infectados, têm uma vida saudável e assintomática. O autor considera esse tipo de caracterização decorrente de um certo sadismo que a sociedade imprime nos indivíduos marginalizados, principalmente, nos homossexuais e usuários de drogas, os mais atingidos pela epidemia no momento do seu estudo. FERREIRA procura ter um outro olhar sobre esses portadores, conferindo-lhes um lugar especial na medida em que os profissionais de saúde tiveram que desenvolver um instrumental específico para lidar com eles, pois os usuais não eram suficientes. Além disso, as angústias primitivas mobilizadas nos profissionais por estes pacientes pôde ser controlada através do desejo de estudar e conhecer o mundo pessoal desses indivíduos. Assim, pelo sofrimento do outro se reconheceu os próprios conflitos (os preconceitos, as angústias, a ameaça aos ideais). Trazer o doente para o centro do foco e atentar para as suas necessidades foi a forma encontrada de enfrentamento da doença, transferindo, de certa forma, o poder médico um tanto impotente frente à doença para a construção do conhecimento em parceria com outros profissionais e com o próprio paciente, agora coadjuvante no tratamento.

Pode-se refletir, nesse sentido, que a aids tem contribuído para fortalecer os preceitos da ética médica. As considerações de PESSOA LABAKI e de FERREIRA tocam diretamente no critério de autonomia da ética, uma vez que o anúncio do diagnóstico privilegia o ser humano como o senhor do seu próprio destino, status anteriormente cedido (ou apoderado) pelo médico, que tinha o lugar de tutor do destino do paciente. Já se adentra no campo do atendimento psicanalítico. 


\subsubsection{O Atendimento Psicanalítico}

$\mathrm{O}$ atendimento psicanalítico foi, dentre outros, um dos instrumentais possíveis para abordar o paciente com aids e muitos trabalhos relatam como foi essa experiência. Seguindo na linha do autor mais próximo do ponto em que este estudo se encontra, apontam-se as contribuições de FERREIRA (1992, 1994b) a esse respeito. Partindo do atendimento hospitalar ao paciente com diagnóstico HIV positivo, ele observa que a letalidade da doença, juntamente com o pouco conhecimento a respeito da mesma, favoreceu a inclusão do psicólogo na equipe. Em seu trabalho de pesquisa estudou 15 pacientes, utilizando o método clínico com referencial teórico psicanalítico. Relata que o paciente, nem sempre dotado da capacidade para cuidar de si, passa por algumas vivências psicológicas que exigem níveis específicos de cuidados (ABRAMS e col. 1986 citados por FERREIRA 1992, p.44). Essas vivências são: a reação ao diagnóstico em que sofre estresse e depressão, necessitando de suporte terapêutico para elaborar a comunicação do diagnóstico, a preocupação com a reação dos outros à doença e como será seu comportamento a partir daí. Frente às doenças oportunistas, o apoio psicoterapêutico poderá auxiliá-lo a expressar seus sentimentos e elaborar as perdas. Por fim, já em fase terminal, o suporte deve-se estender à família, na preparação para a morte, para o não abandono do paciente e para a satisfação de seus desejos. Este trabalho só pode ser realizado se apoiado na transferência positiva, sem a qual a presença do terapeuta torna-se indesejada.

FERREIRA (1992) ainda salienta aspectos psicodinâmicos relacionados ao paciente com aids, que são também inerentes à natureza humana. Considera que o medo da morte é a angústia fundamental do homem, e é essa a primeira a ser mobilizada desde o diagnóstico soropositivo para o HIV. Ressalta que, diante de pacientes vivos e com saúde, pode-se pensar na morte como associada às múltiplas perdas que a aids produziu e ainda irá produzir e não, propriamente, à morte em si, em sua expressão literal.

DIAS (1993) também atendeu doentes de aids em hospital e sintetiza as muitas perdas provocadas pela doença que o portador ou doente vivencia:

- perda do projeto de vida; 
- perda da identidade corporal, temporal e social;

- perda da autonomia e da privacidade sobre a identidade social e

- perda das relações afetivas.

Segundo a autora, a doença expõe uma identidade transgressora e provoca também a eclosão de conflitos profundos e anteriores que, expostos, são carregados de julgamentos e valorização públicos, sociais e morais.

Dentre todas essas perdas que o doente pode sofrer, FERREIRA (1992) atribui como as mais importantes as de relacionamento com parceiros, com familiares, com amigos, etc., frente às quais o mecanismo de negação e o processo de luto tornam-se inevitáveis, podendo esse último evoluir para a melancolia. $\mathrm{O}$ autor discorre sobre estes conceitos, baseando-se no texto freudiano. Segundo ele, concluindo o processo favoravelmente o paciente pode investir em novas relações.

Nos pacientes estudados, o autor observou que o investimento nas relações novas ou já existentes “... iria se refletir de forma significativa na melhoria da qualidade de vida. Isso permite que se compreenda porque algumas pessoas habituadas a hábitos considerados pouco saudáveis, após o conhecimento do diagnóstico do HIV, conseguem uma melhoria significativa em suas relações humanas e em seus hábitos de vida. Das três alternativas de reação aqui levantadas (negação, luto ou melancolia), freqüentemente adotadas pelos pacientes, somente o luto permitiria um bom nível de vida ao paciente, mesmo diante dos limites impostos pela aids" (FERREIRA, 1992, p.52).

Em outro texto, esse autor faz considerações sobre a melancolia, cujos "... traços mentais distintivos são um desânimo profundamente penoso, a cessação de interesse pelo mundo externo, a perda da capacidade de amar, a inibição de toda e qualquer atividade e uma diminuição dos sentimentos de auto-estima..." (FREUD 1917, p.726, citado por FERREIRA 1994b, p.61). No paciente com HIV isso se refletiria em se castigar pelas múltiplas culpas: da infecção, das práticas sexuais promíscuas, dos comportamentos ilícitos como o uso de drogas, etc, podendo culminar em autopunição através da re-infecção e do suicídio. Ele devolve ao seu eu o ódio ao objeto.

No mesmo lugar, o autor continua: "Tanto o luto quanto a melancolia foram precedidos de uma escolha objetal, uma ligação objetal e uma perda do objeto. No 
entanto, no luto há uma retirada da libido do objeto perdido e um deslocamento da mesma para um novo" (p.61). Isso não seria possível na melancolia, em que as perdas são acompanhadas de auto-recriminações intensificadas e vivência de culpa pela infecção, podendo exacerbar sentimentos de ódio em relação a si mesmo e depressão. A libido não se liga a um novo objeto, retorna ao seu eu sob a forma de auto-recriminação e culpa pelo objeto perdido. O paciente pode chegar, em extremo, ao suicídio, que aparece como uma busca de identificação com o objeto perdido.

Investigando a psicopatologia psicanalítica da melancolia, MOREIRA (1997) adverte que, freqüentemente, se associa a melancolia à aids na tentativa de dar conta de situações onde a melancolia decorre da constatação da presença de HIV/AIDS (como relatado por FERREIRA, acima). No entanto, “... será preciso seguir o outro rumo possível, supondo que a melancolia mesma, talvez sob a forma de mania, tenha conduzido já o sujeito à busca ativa, parcialmente inconsciente, da infecção pelo vírus HIV. Teríamos ai ocasião de refletir sobre as razões que levariam alguém a investir num objeto mortífero" (MOREIRA 1997, p.35).

Essa advertência trazida por essa autora é inédita e talvez seja uma suposição até agora não investigada em profundidade em trabalho nenhum, podendo representar uma lacuna no curso dos desenvolvimentos teóricos em torno da epidemia da aids.

Diante desta constatação, MOREIRA (1997, p.35-36) recomenda uma escuta urgente da associação melancolia/aids. "É preciso continuar a escutar atentamente (...) as produções imaginárias que o avanço da epidemia vai produzindo, para que possamos identificar nelas a manifestação da pulsão de morte, que nos habita a nós humanos, e que, no cumprimento de sua tarefa, destina-nos a ir ao encontro do inorgânico".

O texto de MOREIRA vem reafirmar o que foi dito pungentemente por KLOURI dois anos antes, para uma platéia de analistas, a respeito da possibilidade de análise de pacientes soropositivos ou doentes de aids. KLOURI (1995) identifica duas posturas opostas: de um lado uma espécie de recusa dos psicanalistas em escutar as pessoas que se encontram gravemente doentes, angustiadas e aterrorizadas diante da morte e, de outro, os que se propõe a ajudar e obturar a falta, a ferida narcísica e são chamados de "profissionais de ajuda", com um tom irônico e 
pejorativo por parte dos que criticam a iniciativa de aceitar em análise estes pacientes. Sofrem, assim, uma discriminação e são censurados no próprio meio.

A autora defende a idéia de que o indivíduo com uma doença orgânica apresenta necessidades biológicas, mas também, o dom da fala, através da qual faz uma demanda de amor, formulada e dirigida ao outro. No espaço entre a necessidade e a demanda pode surgir o desejo, de onde advém o sujeito do inconsciente. Essa demanda é o que é analisável, que possibilita o campo da transferência e o desenrolar do tratamento. A seu favor, seguindo a mesma linha teórica (a lacaniana), toma a palavra DIAS (1997), também em um evento psicanalítico, dizendo que nenhuma doença consegue recobrir a dimensão da sexualidade e da relação do sujeito com o próprio desejo, que é a dimensão que todos os sujeitos têm.

Enriquecendo a discussão, PESSOA LABAKI (1996) faz uma indagação sobre a clínica psicanalítica da aids, enquanto doença de final de século, e o que ela mobiliza na sociedade e na clínica psicanalítica, considerando como ponto primordial a sexualidade humana. Diferentemente dos últimos autores mencionados, sua linha teórica é freudiana. Aponta para o fato de que a aids muda a cena da erradicação das doenças, decorrente da modernização das técnicas de tratamento e prevenção.

A autora corrobora a opinião dos psicanalistas acima referidos de que não há uma clínica especial para portadores do HIV ou aids, pois a clínica psicanalítica é uma clínica do sofrimento psíquico e esse é próprio do humano e não exclusivo de alguns. Reflete que “... a condição de portar o HIV, por si só, não sustenta um pedido de análise. (...) Não há a priori uma regra de indicação de análise para toda pessoa portadora do vírus. O que supõe um atendimento em psicanálise é o grau de sofrimento conjugado ao desejo de falar e ser escutado, refletir e ser acolhido, trocar a dor por palavra, para poder saber mais sobre aquilo que julga ser o motivo de seu sofrimento e acredita não conhecer (...) A vertente que se coloca é a da produção de singularidades não catalogáveis, nem predizíveis porque o sujeito do desejo não é homogêneo ou finito: é dividido, contraditório e vai se constituindo a partir do seu acontecer" (PESSOA LABAKI 1996, p.158).

Parece que este texto "inaugura" uma mudança de pensamento a respeito da aids. Um novo estágio se apresenta. Até então, além de predominantemente falarem da angústia relacionada à "morte anunciada" a partir do diagnóstico HIV positivo, os 
textos tratavam da questão de como abordar o "novo" analisando. No estágio atual da epidemia, representado pelas considerações de PESSOA LABAKI, o atendimento ao soropositivo ou doente de aids já está consolidado e garantido como um atendimento possível a um ser humano infectado por um vírus que provoca uma deficiência no seu sistema imunológico, ainda sem cura até o momento. Ele é agora incluído, não marginalizado do atendimento. Parafraseando a autora, o indivíduo apresenta um sofrimento psíquico e demanda a análise não só por ser soropositivo, mas por ser pessoa, ser humano, antes de tudo. Acrescenta que o diagnóstico soropositivo para o HIV pode desenvolver na pessoa do portador a “... franca harmonização com as leis maiores da vida e [o] incessante pulsar das causas do desejo" (PESSOA LABAKI 1996, p.159). A aids objetiva, traz a dimensão psíquica de cada um, de forma intensa, terrorífica, num primeiro momento, mas também de cunho elaborativo quando o paciente pode se beneficiar da escuta de um profissional engajado nesse tipo de abordagem da doença. Como se observou nos trabalhos mencionados de PESSOA LABAKI, FERREIRA e DIAS, com a abordagem psicanalítica pôde-se recuperar recursos egóicos defensivos dos pacientes, o que se verificará a partir de agora nos estudos de SANCHES $(1997,2000)$ e outros autores. A autora obtém relatos de soropositivos em que aparecem reações semelhantes de reconstrução de vida, denominadas por ela de ressignificações.

SANCHES (2000), utilizando as teorizações de WINNICOTT, analisa a dinâmica psíquica envolvida nos sujeitos em geral e no portador do HIV/AIDS em particular. Considera que, sob o falso self se esconde, durante toda a vida, o verdadeiro self ao qual estão ligadas a pulsionalidade e a agressividade. A revelação [do HIV positivo] é uma ameaça tanto temida como desejada. Isso significa que, por um lado, o self verdadeiro é significado como algo desprezado e perigoso para o próprio indivíduo e para o outro (pelas significações vinculadas socialmente ao vírus HIV), mas por outro lado, pode existir esperança de que o intolerável possa ser acolhido e aceito. Inconscientemente, o indivíduo que se expõe ao vírus ou que tem a fantasia de infecção, não somente faz um movimento auto-destrutivo movido pela culpa, mas também pode estar à procura de uma função continente para aspectos de sua própria sexualidade e agressividade aprisionados até então. Tornar-se doente, no concreto ou na fantasia, pode ser uma forma de tentar se ver reconhecido, acolhido 
na dor e na verdade, modificando a experiência primitiva insatisfatória por um ambiente "suficientemente bom" (destaque da autora). Sua busca é por cuidado, mesmo tendo que pagar um preço alto do ponto de vista físico, social e psíquico.

Nesse processo, de acordo com SANCHES, as saídas podem ser: entrega, fuga e elaboração. Nem sempre um caminho exclui o outro.

Na entrega, a Aids Mental ${ }^{*}$ se sobressai “... o indivíduo passa a viver a morte em vida: as possibilidades de prazer, de criação, de vida são assassinadas (...) e a expectativa de vida diminui significativamente" (SANCHES 2000, p. 251-2).

$\mathrm{Na}$ fuga, existe a possibilidade de uma reorganização do sistema defensivo de forma rígida. O indivíduo pode se considerar vítima e/ou herói, como ganho secundário da constatação do HIV, vivendo assim até que as defesas se desorganizem.

O caminho mais difícil é o da elaboração. Ele envolve a necessidade de se defrontar com os fantasmas, com tudo que se teme e se esconde. Isso pode ocorrer pelo uso da palavra que dá significado à situação traumática, segundo DOLTO (1989), citada por SANCHES (2000, p.252). Mas, voltando à concepção winnicottiniana, seu referencial de análise, a autora conclui que a experiência de compartilhamento não só da palavra, mas de tudo o que o contexto de um ambiente “suficientemente bom” proporciona, alcançará aspectos do verdadeiro self até então inacessíveis. A dor, assim dividida com o outro, tornar-se-á mais suportável, podendo haver a abertura do caminho para a elaboração e para a vida. Os ganhos secundários são o alívio pelo desvendamento da parte oculta e o sentir-se vivo por ter enfrentado e sobrevivido à catástrofe. Para SANCHES, torna-se, então, possível ao indivíduo sublimar e criar, ampliando as possibilidades de elaboração. O mecanismo psíquico de sublimação e a capacidade criadora são condições essenciais para a saúde.

SANCHES (2000) considera que isso só será possível com uma modificação do setting, permitindo a emergência de conteúdos de não-integração. As necessidades egóicas, assim satisfeitas, ocasionarão o fortalecimento do ego.

A autora ressalta, finalmente, que a aids pode “... ser inconscientemente

\footnotetext{
* AIDS Mental “... um estado mental caracterizado pela fantasia, baseada ou não na realidade, de se estar contaminado pelo vírus HIV” (SANCHES 2000, p.241).
} 
procurada: num movimento auto-punitivo, impulsionado pela culpa (aspecto não desenvolvido nessa tese); para nomear o inominável (destrutividade, agressividade), assumi-lo como seu e ao mesmo tempo negá-lo; numa tentativa de romper estruturas falso self, em colapso. Aspectos clivados aparecem (explícita ou projetivamente) na procura de um ambiente suficientemente bom, continente" (SANCHES 2000, p.2534) (destaque da autora).

Dependendo da organização (ou não) do self verdadeiro, poderá haver um rompimento da estrutura falso self, permitindo que um novo ambiente "suficientemente bom" se constitua. Isto é fundamental, segundo a autora, para a passagem da sobrevivência à existência, ao SER.

CIPRIANO (1999), adepto de outra linha teórica, a freudiana e a de Fábio HERRMANN, chega a conclusões interessantes e significativas a respeito da dinâmica psíquica dos soropositivos e doentes de aids, a partir do acompanhamento de pacientes em psicoterapia. Diz ele:

“... a [infecção] pelo HIV não é uma dádiva e não conduz, necessariamente, a um processo de crescimento e maturidade emocional. A situação apresenta-se de forma complexa, diversificada, heterogênea; é curioso como insistimos em simplificar determinadas situações, em reduzi-las a denominadores comuns" (CIPRIANO 1999, p.128). Isto é o contrário da hipótese inicial do autor, que acreditava na possibilidade de amadurecimento emocional das pessoas a partir do diagnóstico HIV positivo.

CIPRIANO continua suas considerações acrescentando que tomar o HIV como uma condenação (opondo-se à sua colocação anterior) foi o dado mais comum encontrado entre as pessoas pesquisadas e entre a maioria dos seus parceiros, familiares, médicos, etc.

$\mathrm{O}$ autor, após os quatro anos em que desenvolveu sua pesquisa, considera que o HIV/AIDS não é nem dádiva, nem condenação. "É um fenômeno complexo, que atinge importantes esferas da vida individual e coletiva, um evento raro, uma condição, que pode se transformar numa doença ainda incurável. É isso, nada mais nada menos" (CIPRIANO 1999, p.128).

Afirma que não se pode dizer se houve um processo de ressignificação das vivências afetivas e das condutas sexuais dos pacientes acompanhados, pois as 
transformações dessas fazem parte de um processo onde se deve focalizar a organização psíquica do paciente como um todo. CIPRIANO (1999) ressalta que é mais consistente tentar compreender uma determinada atitude ou mudança de atitude em função da organização psíquica do paciente do que atribuí-la ao fato dele estar infectado pelo HIV. O autor confirma sua conclusão utilizando um caso clínico que não cabe relatar aqui. O HIV não altera condutas e significados, quem o faz é a pessoa em função do seu modo de ser, do seu funcionamento psíquico.

Essa constatação é muito importante e pode ser aplicada aos programas de prevenção que focalizam principalmente mudanças de atitudes e práticas (comportamentos) e quase nunca a singularidade. Entende-se que quando se focalizam populações a serem informadas e orientadas, volta-se mais para a dimensão coletiva ou de massa, mas essa é formada por sujeitos, cada qual com suas particularidades. Isto pode ser considerado um desafio, ou seja, atingir o maior número possível de pessoas e, ao mesmo tempo, o funcionamento psíquico de cada uma delas.

$\mathrm{O}$ autor constatou que a infecção repercute de forma diversa em cada um, sem um padrão determinado, como já foi salientado no item "Impacto do diagnóstico" por outros autores. Em alguns casos estudados por ele, a soropositividade levou ao amadurecimento emocional e à conquista de um funcionamento psíquico mais eficiente, acelerando um processo. Em outros casos, a infecção foi essencial para a conquista da autonomia frente aos referenciais de identidade. "A soropositividade arrebentou com um modo de ser cristalizado e aprisionador, revelou intenções, impediu o disfarce, forneceu a dimensão exata para cada experiência” (CIPRIANO 1999, p.131), uma evidência muito semelhante à encontrada por SANCHES (2000), na sua referência ao falso e verdadeiro self. A infecção pelo HIV obrigou o paciente a se haver com as próprias dificuldades. Em alguns casos, o HIV é assimilado ao processo de amadurecimento emocional já em curso, sendo mais um acontecimento em suas vidas, e, dependendo da forma de vivenciar do paciente, pode funcionar como um coadjuvante em suas atuações. [O autor está se referindo a um dos seus entrevistados]. A infecção, para um dos pacientes, funcionou como um atestado às suas dificuldades, ao seu desequilíbrio emocional, sendo resultado de aspectos autodestrutivos já existentes, não sendo assimilada e nem desestabilizando um modo 
de ser. Para outro, deixou-o em suspenso, impedindo-o de agir. O paciente “... não sabe mais ser" (CIPRIANO 1999, p.132).

Para o autor, o processo de construção da identidade resulta de mecanismos e processos que são responsáveis pela constituição do sujeito. Estes estão relacionados aos conflitos e conteúdos emocionais que dependem do ajuste entre si, do qual decorre a organização psíquica. Utilizando a noção de inconsciente relativo (HERMANN) em que a ruptura de campo promove o choque entre representações, CIPRIANO adotou a perspectiva de compreender o ajuste e a articulação das representações dos pontos de vista tópico, econômico e dinâmico. Dos conjuntos de representações/significados se estabelecem a correspondência ao padrão de organização psíquica dos nove pacientes pesquisados e os referenciais de identidade que eles expressam. O autor chamou de "estratégia psíquica" os modos de ser de cada paciente, encontrando diversas estratégias. $\mathrm{Na}$ sua opinião “... existem determinados aspectos do existir que são o resultado da totalidade da organização" (CIPRIANO 1999, p.138). Os recursos psíquicos utilizados, segundo o autor, são: o direcionamento de determinada organização (quando os conjuntos de significados expressam a mesma forma de ser ou formas de ser que não se excluem), a sobreposição (a utilização de características comuns entre conjuntos de significados que se fortalecem) e a fixação (que promove a rigidez). A cada conjunto de significados estão associadas as condutas dos pacientes investigados que são produzidas por esses modos de funcionamento psíquico. CIPRIANO não desconsidera a perspectiva dos mecanismos identificatórios para a compreensão do processo de construção de identidades, mas propõe uma interdependência entre essa modalidade e a que descreve, que é baseada nos modos de ser/funcionar dos indivíduos.

Segundo observaram CIPRIANO (1999) e SANCHES (2000), a infecção pelo HIV parece ser um evento desencadeante de um amplo processo de transformação da personalidade do indivíduo no sentido de acionar todos os seus recursos disponíveis para tornar possível a elaboração. Esse processo pode provocar uma atitude criativa por parte do indivíduo, dada a urgência da solicitação ou, pelo contrário, pode ser fonte de desorganização.

ABDUCH (1997) desenvolve uma tese de doutorado, cujo objetivo é verificar a 
relação entre integração psíquica e fragilidade diante do vírus da aids, tanto em mulheres soropositivas, quanto naquelas portadoras da doença, tendo como instrumento o teste de RORSCHACH, avaliado segundo a teoria de WINNICOTT.

A autora constatou que as mulheres portadoras do vírus apresentavam-se, do ponto de vista psíquico, menos integradas que aquelas que já desenvolveram a doença. Defende a hipótese de que a falta de integração desses grupos de mulheres ocorre devido às falhas precoces no seu desenvolvimento maturacional, falhas de adaptação mãe-bebê que, provavelmente se mantiveram no decorrer de suas vidas. Essa falta de integração resulta num precário contato com a realidade externa. No caso da aids ela pode se manifestar através da negação da doença. "Em função das características precípuas da doença, a aids tende a aparecer mais tardiamente nestas mulheres menos conectadas com a sua realidade de soropositivas; isso porque o vírus HIV atua no sistema imunológico cuja depressão está intimamente associada à depressão emocional" (ABDUCH 1997, p.150) (destaque da autora).

Continuando sua interpretação a autora escreve: "Mulheres mais integradas psiquicamente tendem a receber simbolicamente o vírus, já que este é para elas um dado de realidade e deve ser simbolizado e não negado. (...) as mulheres que mais viveram foram as que desenvolveram mais rápido a doença. (...) A morte aproximouse com mais veemência das mulheres mais receptivas à vida. (...) [mas] encontram-se em momento de criatividade" (p.151-2). E isso ocorreu com serenidade, garantindo sua existência enquanto ser. (destaques da autora)

ABDUCH sugere que nas mulheres com aids, a doença e o sentimento de morte eminente podem ter sido um fator integrador. Esta última afirmação, colocada de uma forma um tanto "mágica", não está subentendendo que o ser humano para se transformar tenha que sofrer. Vale a ressalva de que o estudo de ABDUCH focalizou alguns casos, não tem pretensões de generalização. É mais um achado que se coteja aos demais no presente estudo e é dotado de sentido que auxilia a compreensão do tema. Entretanto, a autora repete uma caracterização das pacientes envolvidas em sua pesquisa que produz um certo incômodo. Trata-se da expressão utilizada para diferenciar as mulheres que já desenvolveram a doença das demais mulheres. A autora assinala constantemente que as mulheres que ainda não desenvolveram a doença (as assintomáticas) são as apenas soropositivas. Este “apenas” acaba tendo 
um caráter pejorativo que subestima esta condição, pois, não são apenas soropositivas, são soropositivas assintomáticas.

A exemplo de Franz ALEXANDER que se propunha a não estabelecer perfis, mas ao elaborar suas proposições causou a impressão de que já os estabeleceu, as conclusões de ABDUCH soam como catalográficas, parecendo querer justamente estabelecer perfis para a condição das mulheres quanto ao processo saúde-doença em cada grupo estudado. E se, em seguida, as "apenas" soropositivas apresentassem sintomas? Acaso mudariam sua constituição de self e sua integração psíquica? Afinal, não tiveram uma boa adaptação mãe-bebê, conforme a autora concluiu... Passariam a ter? É importante se fazer uma reflexão em torno desse tipo de colocação, pois, a palavra escrita pode gerar interpretações diversas e discordantes das intentadas pelo seu autor, como já disseram os teóricos comentados no capítulo metodológico do presente estudo. A aids é uma doença “mestra" em também gerar interpretações e manifestações conflitantes. (destaques nossos)

As linhas teóricas psicanalíticas, por seu lado, apresentam-se ora aproximadas, ora afastadas ou mesmo incompatíveis. Portanto, é necessário que se tenha um grande cuidado com os termos que se usam, para não marcar, estigmatizar, separar, discriminar e colocar o sujeito à margem, do outro lado dos muros da cidade, como um estranho, um estrangeiro. Favoreceria um certo retorno aos anos oitenta onde o tom e a mensagem, até das campanhas bem intencionadas de prevenção, tinha o dom de manter oculto e secreto o que se manifestou, podendo gerar mais medo, sofrimento, isolamento e solidão (CALEIRO COSTA 1991). Enfim, a expressão “apenas soropositivas", pode representar que "apenas se banaliza", ou se minimiza essa condição. Nessa linha de raciocínio, mais cautelosa com as palavras, RUIZ (1999) propõe ao final de seu trabalho, Considerações Finais e não Conclusões, por julgar que os seus achados não fecham, mas lançam questões sobre o tema.

A autora, "escutando" as representações mentais de pacientes com aids e suas possibilidades de elaboração, objetivou cotejar a teoria freudiana e desenvolvimentos de Fábio HERMANN para melhor compreender a realidade psíquica desses pacientes. Aponta uma síntese dos dados com aspectos comuns observados nos quatro casos que acompanhou, dando uma visão amostral do funcionamento psíquico diante da aids. Longe de fazer uma tipologia ou de elaborar um perfil psicológico do 
doente de aids, RUIZ pretendeu assimilar alguns pontos que se repetiram em cada sujeito pesquisado. Considera: “O que é universal (...) é o funcionamento psíquico, o modo de operar da psique humana (...) a existência de uma superfície representacional que tem função defensiva e é sustentada pela crença, e que, no processo de análise, é posta em xeque em diversos pontos. Como isto se dá em cada indivíduo, o que cada um faz com isso, consciente ou inconscientemente, é que é particular" (RUIZ 1999, p.141).

Assim, em todos os pesquisados, observou o sentimento de culpa associado ao meio de infecção e que, na teoria psicanalítica, é explicado pela repreensão que o próprio sujeito faz de seus atos. E são os atos que o adoeceram pelo HIV, daí o sentimento de culpa aflorar. Em conseqüência desse sentimento e do abalo sofrido na superfície representacional, ambos decorrentes do contágio pelo HIV, surge a negação, o mecanismo utilizado que promove a condenação das próprias práticas sexuais, quando estas foram as fontes da infecção. Isto provoca um abalo na identidade, uma vez que essa é decorrente de uma realidade forjada por estas práticas. "A identidade, então, ameaçada, tem de defender-se e, dentre tantas outras possibilidades, também o faz encobrindo suas representações relacionadas à sexualidade, considerada, então, 'errada', desviante, perigosa, enfim, a grande culpada pela [infecção]” (RUIZ 1999, p.143) (destaque da autora).

Houve, em algum momento, fixação na representação de "aidético" (destaque da autora), com imobilidade e rigidez na identidade, mecanismo igualmente evidenciado por CIPRIANO (1999), lembrando que ambos autores elegem a mesma abordagem teórica.

RUIZ observa, ainda, que as representações associadas à aids foram negativas, pois estavam ligadas a conflitos, culpa, sofrimento, castigo e morte, presentes em todo o período pesquisado pela autora.

Finalmente, ela lembra NIETZSCHE: “... que o pensar sobre a doença não cause ainda mais sofrimento que a doença em si” (RUIZ 1999, p.144), refletindo que isso ocorre quando não há possibilidade de elaboração dos sentimentos ligados à doença e suas representações e de outras formas de "ser" e "estar no mundo", tarefa que a psicanálise se propõe a fazer.

Encerrando as considerações sobre o tema da dinâmica psíquica 
compreendida sob a ótica do atendimento psicanalítico e da "escuta dos analistas", serão feitas algumas incursões em sub-temas tratados em alguns textos: a representação que a criança tem da doença, a dinâmica psíquica dos usuários de drogas e as vicissitudes do atendimento ao paciente homossexual.

Um único trabalho abordou o tema da criança e do seu funcionamento psíquico perante a doença. Trata-se do texto de COSTA (1994), ainda graduando-se em Psicologia. Seus objetivos foram: conhecer as fantasias e medos que a criança desenvolve, as emoções despertadas e a forma como ela lida internamente com essas emoções, bem como identificar quais os mecanismos de defesa que ela utiliza, quais as forças internas de que abre mão, quais as formas de comunicação em termos de mensagens que ela envia e os sinais que são manifestos em seu comportamento.

A autora elabora uma análise psicodinâmica dos desenhos-estória das crianças de uma instituição para crianças soropositivas, técnica reconhecida e recomendada para esse fim.

Constatou que as crianças dessa instituição encontram-se fragilizadas e inseguras frente ao ambiente externo, visto como ameaçador e frente ao qual utilizam uma defesa no contato social. Apresentam dificuldade de lidar com os conflitos internos e bloqueio da fantasia para a elaboração desses conflitos, o que as deixa numa situação mais vulnerável e impotente.

Abre-se um parêntese para um comentário envolvendo a percepção de crianças da mesma instituição, seis anos depois, feito por outro pesquisador (BARRERO 2000). Paradoxalmente, o que foi mostrado nesse trabalho, premiado no Fórum 2000, Congresso promovido no Rio de Janeiro pelo Ministério de Saúde em cooperação com os países da América Latina e do Caribe, foi que a visão das crianças dessa e de outras três instituições pesquisadas, de apoio aos portadores do HIV/AIDS, é otimista. Nesse estudo foi utilizado o método etnográfico e foram comparadas as experiências de vida das crianças de 3 a 13 anos portadoras do HIV, assistidas por essas instituições, com as experiências das crianças moradoras da rua. Os resultados apontaram similaridades e diferenças entre os dois grupos de crianças quanto à eficácia das respostas sociais dadas a cada um deles, e o significado social que cada grupo representa. Apesar de compartilharem histórias de vidas passadas similares (pobreza, desestruturação familiar, consumo e tráfico de drogas), crianças afetadas 
pelo HIV têm melhores condições e perspectivas de vida que as crianças de rua não infectadas. O pesquisador concluiu que a epidemia do HIV no Brasil tem ajudado a entender as dinâmicas de exclusão social. As condições de vida adversas, inicialmente compartilhadas pelas crianças com HIV e pelas crianças de rua, têm sido modificadas somente para as primeiras. Ao contrário, crianças de rua têm recebido repressão e exclusão em vez de assistência adequada. O fato do HIV ter afetado grupos sociais com poder político, acadêmico e econômico resultou em respostas sociais mais adequadas. Aqueles que experienciam outros fatores de violência estrutural não recebem respostas oficiais adequadas e sentem pouco impacto do ativismo das ONG.

Fecha-se o parêntese atentando para o fato de que se pode colocar objeção quanto a se introduzir um estudo não psicanalítico, que trata de aspectos mais sociais em uma discussão de textos nessa linha teórica. O argumento a favor é o de que sua inserção cumpre o papel de apontar a evolução e mudança no perfil da epidemia, através da multiplicação das ações, justamente no que diz respeito às aspirações feitas por COSTA (1994) relativas às representações da doença e da própria vida das crianças institucionalizadas. É muito gratificante perceber uma mudança na resposta social frente ao problema infantil, que pode ser responsável por uma diminuição da vulnerabilidade das mesmas.

Reforçando essa idéia, a pesquisadora relata que, no momento de sua pesquisa, as crianças não eram informadas de sua condição sorológica. Então, quando alguém adoecia e era internado acentuavam-se as fantasias acerca do que aconteceria com elas. Além disso, havia a dupla mensagem representada pela omissão da doença real e pelo tratamento dispensado a elas como crianças doentes. Portanto, “... não são doentes, mas são tratadas como se fossem..." (COSTA 1994, p.29). E se indagam: Quem passa mal e vai para o hospital não volta mais. O que aconteceu?

Reagem de forma agressiva ao mundo, parecendo ser esta a única forma que aprenderam de se relacionar com ele.

COSTA levanta a hipótese de haver uma carência afetiva que contribui para a busca de afeto e fragilidade das crianças. Mostram-se ambivalentes em seus sentimentos frente às "figuras maternas", cuja presença é restritiva frente às necessidades das crianças. 
A representação mental da doença é particular, proveniente de sua história de vida e da instituição que as abriga. $\mathrm{O}$ ambiente externo ameaçador e destrutivo é projetado na efetivação da doença que possuem.

Apesar de serem representações infantis, verificam-se semelhanças entre essas representações e as dos adultos estudados e referidos nos trabalhos anteriores. A psicanálise possui uma explicação, que independe da idade cronológica, pois se tratam de representações mentais conscientes e inconscientes. As representações mentais inconscientes são atemporais e ambas, as conscientes e as inconscientes, são estruturadas em um psiquismo em constante movimento de troca com o ambiente durante toda a vida. $\mathrm{O}$ adulto, nas suas vivências atuais, faz um constante retorno do recalcado que são os traços de memória imantados no inconsciente. Neste processo ele significa e ressignifica continuamente suas experiências infantis.

KLOURI (1992, 1993), atendendo usuários de drogas em um hospital especializado em doenças infecto-contagiosas, conclui, em seu estudo, que o uso de drogas é uma espécie de dependência humana, cuja origem encontra-se em etapas primitivas do desenvolvimento infantil, e que se manifesta em geral na adolescência. Faz uma análise de como isso se insere na teoria das relações objetais, especialmente no modo como os seus entrevistados lidavam com as perdas, principalmente, quando estas estavam relacionadas a pai e mãe. A droga “... possibilitava um retorno ao mundo infantil do narcisismo, da onipotência, da dependência. (...) havia um investimento maciço da libido na cocaína, mas que não chegava a constituir uma relação de objeto, uma vez que a finalidade de tal investimento era o retorno da libido ao próprio ego, através da incorporação da droga, uma maneira de negar a falta, e acreditar no prazer perfeito" (KLOURI 1992, p.122-3). Assim, estes indivíduos têm um prazer consigo mesmos, não entram em contato com a castração e a angústia decorrente dela, vivendo uma completude e onipotência imaginária. A autora aprofunda sua análise psicanalítica baseada em seus dados, porém, como aqui se pretende enfocar a questão da aids, este será o assentamento principal.

Os entrevistados por KLOURI, todos portadores do HIV e com a dinâmica psíquica superficialmente descrita aqui, só se preocupavam em obter aquele tipo de prazer, não se importando com os riscos, seja de contrair infecções, seja de overdose. Implícito nesse funcionamento estava a "picadomania" (termo usado por 
OLIEVENSTEIN (1980), citado por KLOURI neste estudo, p.128) e o masoquismo, em que a pulsão de morte retorna ao próprio corpo, liga-se à libido e mantém o narcisismo. Segundo a autora, alguns entrevistados “... lidavam com a morte de uma forma [também] onipotente, desafiando-a e imaginando que poderiam controlá-la e vencê-la" (KLOURI 1992, p.129). Essa idéia parecia associada ao prazer, quando não negada.

O temor da morte não parece ser o mais relevante, mas sim o temor do desfiguramento e alteração na imagem corporal, que a autora associa ao narcisismo e onipotência ameaçados. "Preferiam a morte concreta a ter que se defrontar com a ferida narcísica e a angústia de castração que a doença evocava" (KLOURI 1992, p.132-3), pois ela também estava relacionada às limitações e perdas decorrentes da aids (amigos, parceiros, trabalho, etc.). Diante disso, um dos mecanismos de defesa evocados, também observado com freqüência em outros estudos assinalados neste trabalho, é o da negação.

A dinâmica do paciente homossexual, maioria dos atendidos por COSTA e MELLO FILHO (1987 e 1988), foi abordada segundo a linha teórica freudiana. Essa concepção considera como determinação da escolha de objeto homossexual a forte ligação com a mãe, o narcisismo e o temor da castração. Levantando trabalhos de outros autores, COSTA e MELLO FILHO (1987, p.44) consideram que o problema básico da homossexualidade parece estar ligado à “... não aquisição de uma sólida e saudável identidade sexual, havendo, muitas vezes, identificação com o genitor do sexo oposto". Ressaltam que não se deve ficar preso a padrões psicodinâmicos rígidos e pré-fixados, uma vez que cada pessoa se organiza psiquicamente de modo diferente, sem deixar de levar em conta a homossexualidade "eventual", diferente daquela que se mantém ao longo de toda a vida (destaque nosso). Apesar dos homossexuais serem cercados, ainda hoje, de preconceito e rejeição, seus maiores problemas se referem aos próprios conflitos com a escolha sexual. Vivenciam sentimentos de vergonha e culpa, tensões e conflitos, na grande maioria, com dificuldade de estabelecimento e manutenção de vínculos fortes e estáveis - não que muitos não o consigam. Entre os próprios homossexuais há um "duelo" ativo versus passivo com forte depreciação dessa última posição. Aqueles que são promíscuos, submetem-se a práticas indiscriminadas, expondo-se ao risco de 
contágio pelo HIV e outras DST e a condutas sadomasoquistas que podem ser exemplos de psicopatologias.

Em outro trabalho, em que um dos autores (COSTA) acompanha um paciente com aids, particulariza-se a questão do atendimento psicanalítico ao indivíduo com escolha sexual homossexual. COSTA e MELLO FILHO (1988) apontam que o relacionamento entre as figuras parentais pode mesmo se imbricar na gênese do comportamento homossexual, embora não queiram que isto seja tomado como um clichê. No caso deste paciente, tinha a ver, inclusive, com sua escolha "passiva" e sua identificação com a figura materna e distanciamento da figura paterna.

O paciente tinha atitudes pregressas maníacas para tentar superar suas angústias, advindo daí, provavelmente, seu contágio pelo vírus HIV através da prática sexual com vários parceiros, após o rompimento com um companheiro. Os autores consideram isso como uma perversão da sexualidade aliada ao masoquismo e autodestrutividade.

Por outro lado, a busca e manutenção de um parceiro fixo até a sua morte demonstram que o relacionamento homossexual pode ser estabelecido com compreensão e respeito e não ser, necessariamente, um vínculo perverso. A relação médico-paciente (e toda a equipe), sendo positiva, propicia um suporte para a manutenção dos tratamentos, às vezes difíceis. Inclui-se aí, a possibilidade de atendimento na enfermaria, no ambulatório e na casa do paciente, ampliando-se muito o conceito de setting terapêutico.

A empatia (compreensão do paciente através da possibilidade de se colocar na posição do mesmo) deve ser exercida e desenvolvida em pacientes somáticos. Falhas neste aspecto podem ocasionar sofrimento do paciente, que não se sente atendido em suas necessidades psicológicas. "Saber ouvir, permitir uma relação em setting não rígido, estava de acordo com as necessidades do paciente que pedia um compromisso por parte de quem vai acompanhar, pois ele remove céus e terra para chegar numa sessão, por exemplo, desejando que eu correspondesse à intensidade deste vínculo" (COSTA e MELLO FILHO 1988, p.24).

O paciente que COSTA acompanhava piorou consideravelmente após a perda do pai, com quem não conseguia ter uma boa relação. Não houve possibilidade de reparação dos danos da mesma e o paciente apressou o seu fim, numa tentativa, 
segundo os autores, de se culpar em relação à morte do pai.

Diante das características, o trabalho de atendimento dos pacientes pelos profissionais, no caso, os autores, foi considerado difícil tanto no que diz respeito à coleta de dados, quanto à intervenção propriamente dita, que, freqüentemente, envolveu terceiros. Os pacientes em geral se recusavam a comunicar a doença e a homossexualidade à família. A família, por sua vez, também resistia a aceitar a "nova" realidade (destaque nosso).

Os autores acrescentam que o processo de morrer causa um sofrimento muito evidente que começa pela internação que já separa o paciente do seu parceiro, família e amigos. Se o paciente é colocado na ala hospitalar de isolamento, a angústia se intensifica ainda mais. É como se fosse "uma morte em vida" (destaque dos autores). Se o espaço se abre para o diálogo, para falar da morte, da vida, dos temores, pode haver um rebaixamento da angústia e a obtenção de uma certa tranqüilidade pelo paciente e não o vazio causado pela evitação do assunto por todos.

Tenta-se encerrar o capítulo do atendimento psicanalítico e suas vertentes, na certeza de ser essa, uma missão impossível, pois é ele que permeia todas as outras temáticas, sendo sempre referência para elas. Assim, sua repetição torna-se inevitável.

\subsubsection{Reflexões Teóricas Frente à Epidemia}

A categoria analítica que ora se principia a abordar pretende enfocar a forma como os autores fizeram uso da psicanálise para estudar o fenômeno da aids.

Tomando como ponto de partida a psicossomática psicanalítica, que também é uma abordagem do dinamismo psíquico do ser humano, encontram-se alguns trabalhos: VASCONCELLOS (1992), MOREIRA (1998), PRZEMYSLAW (1998) e SANCHES (2000). No tema psicoimunologia, parente próximo, assinalam-se os trabalhos de COSTA e MELLO FILHO (1987), COSTA, LIMA e MELLO FILHO (1989) e PEREIRA (1994).

VASCONCELLOS (1992) reflete sobre a morte como resultante de uma dinâmica desencadeada pelo inconsciente humano que torna o homem o autor da sua própria morte. $\mathrm{O}$ autor afirma que “... com exceção dos acidentes involuntários, a 
morte é, sempre, psicossomática" (p.35), posição compartilhada por autores da linha psicossomática já citados no presente estudo, ALEXANDER, MARTY e GRODDECK, esse último também escolhido por VASCONCELLOS.

$\mathrm{O}$ autor não nega que o órgão adoece e coloca em risco a harmonia funcional de todo o organismo, mas afirma que esse órgão só desencadeia o processo patológico e/ou fatal quando o inconsciente humano resolve romper com o equilíbrio homeostático. Confirma com uma citação de FREUD: “o organismo quer morrer, mas à sua maneira" (FREUD citado por VASCONCELLOS, p.35). E continua: "Cada ser humano tem seus motivos pessoais e individuais para morrer. Morre em virtude deles, não em virtude de vírus e patologias. Ainda que elas, inegavelmente, existam" (p.36).

Nessa análise, VASCONCELLOS não exclui as relações sociais e afetivas como um fator central do processo de vida e morte, pois a psique humana depende do amor para se manter pulsando. Sua perda é um fenômeno mortal, causando uma ferida narcísica profunda diante da qual o homem tenta defender-se da fatalidade que o envolve. Segundo o autor, nesse processo ele mobiliza tanta energia tentando imunizá-la, neutralizá-la, que termina por adoecer. Alguns não resistem e morrem. É o que o autor denomina "introversão da relação objetal libidinosa".

Muitos indivíduos quando tomam conhecimento de sua soropositividade passam a relacionar-se apenas consigo mesmos enquanto abominam seu corpo erógeno, como foi observado também no trabalho de KLOURI (1992). "O ser humano resolve com a enfermidade e a morte o conflito entre a perda do outro e a necessidade de ser amado (...). Narcisismo é o desejo de ser desejado. O mais desejado. Necessitamos disso para que possamos nos sentir completos, perfeitos" (VASCONCELLOS 1992, p.36).

Na seqüência, MOREIRA (1998, p.27), preocupada com os problemas da clínica contemporânea com pacientes com HIV/AIDS, debate sobre a mesma, indagando se o analista está preparado para enfrentar a realidade de que “... a cada 20 minutos uma pessoa está sendo [infectada]".

Considera que o analista, ao se defrontar com o inesperado do que é trazido pelo paciente soropositivo, pode incorrer em perigos do tipo: vivenciar um misto de terror e piedade, mergulhar em sentimentos de raiva, revolta, ou cair paralisado, 
numa espécie de luto antecipatório pensando que breve este cliente o abandonará. Pode também entrar num tipo de "furor terapêutico", querendo conservar a vida do paciente e sentir-se culpado pela sua doença, semelhante ao que FREUD chamou de "culpa do sobrevivente" (destaque da autora).

MOREIRA caminha pela linha do fenômeno da depressão e da melancolia, tendo como pano de fundo a luta entre as forças de Eros, representado pelas pulsões de autoconservação e Thanatos, pela pulsão de morte. A autora faz a associação entre os fatores que levam a uma queda nas defesas imunitárias, tendo como principais, o stress e a melancolia decorrentes da comunicação do diagnóstico. Assinala a dificuldade de se fazer uma escuta quando se mesclam a resistência (no sentido analítico do tema), o mal-estar e dor orgânicos, impeditivos reais. A ameaça à integridade do sujeito não é só imaginária, mas concreta, real.

O diagnóstico da depressão, nesses casos, é complexo, pois os sintomas tanto podem ser decorrentes da presença da aids, quanto do processo patológico primário subjacente. Como atribuí-los a uma ou a outro? Em conseqüência, como esperar que o sujeito esteja adequado às exigências do tratamento tão rigorosamente estabelecido, de ingestão de medicação, se está envolvido pela melancolia, destituído de investimento narcísico, amor próprio e desejo de viver? Neste ponto, a autora cita a concepção de melancolia de FREUD e a diferencia do fato de o doente estar com aids, mas ter seu amor próprio preservado (pela ausência da melancolia) condição necessária para um tratamento clínico, não necessariamente psicológico.

"Eros, aquele que é invocado em todo ato de ajuda presente no ofício clínico, e que sucumbe onde a melancolia instala-se, geme, acossado por mortíferas ameaças” (MOREIRA 1998, p.31).

PRZEMYSLAW (1998) elabora um texto complexo, fazendo uma articulação entre o fenômeno aids e uma visão psicanalítica com o uso de conceitos freudianos e lacanianos. De seu trabalho podem-se extrair algumas considerações importantes.

$\mathrm{O}$ autor discute as relações psicanálise-sexualidade-aids, indagando sobre qual referencial psicanalítico pode ser utilizado diante da plasticidade da realidade da sexualidade e do erotismo. Questiona sobre os tótens nosológicos que podem ser utilizados para observar essa realidade sem preconceitos. E traz “... uma contribuição da teoria dos instintos, particularmente necessária para a compreensão 
desta ocorrência da destrutividade patológica que traz na sua gênese duas compulsividades: uma ao nível das práticas sexuais sob o signo do êxtase total e ilimitado, outra, ao nível somático, mais especificamente do sistema imunológico" (PRZEMYSLAW 1998, p.221).

O autor desenvolve seu texto tentando não estabelecer qualquer postulação normativa em torno da consideração da perversão/compulsão apenas em termos pulsionais.

Neste sentido, o autor aponta que o homossexualismo não é tomado como perverso em si: “... vamos reservar a categoria de perversão para as compulsividades que se marquem mais pelo gozo destrutivo, como, por exemplo, as promiscuidades sem nenhuma preocupação com a segurança tanto do sujeito como do(a) parceiro(a)" (PRZEMYSLAW 1998, p.222).

Assinala também, as mudanças culturais rápidas e radicais com implicações na "moral sexual civilizada" que, segundo FREUD (1908) citado por ele, era responsável pelo aumento da doença nervosa na modernidade. PRZEMYSLAW discorre sobre o texto de FREUD, salientando que o conflito do homem moderno para a satisfação pulsional, muitas vezes pende para a transgressão dos princípios éticos e dos ideais em prol dos prazeres e do gozo total, fruto de um narcisismo alienante. Nesse contexto, instalam-se as perversões, antes ocultadas, agora “... elementos de autopromoção no mercado erótico..." (PRZEMYSLAW 1998, p.223) e no seu bojo, a aids, revelando de forma trágica as conseqüências do prazer sem limites que o autor associa a Sodoma e Gomorra em versão atual. Ainda citando FREUD, destaca a falta de possibilidade de conciliar os instintos com a norma social, que cria uma moral "dupla": a visível, que concilia os interesses do sujeito com a sociedade, e o cinismo, que impossibilita essa conciliação. O autor acrescenta ainda, a questão do narcisismo legitimado na subversão individualista do sujeito para se defender da massificação. “... o século XX promoveu uma reconquista do corpo erógeno, ainda que fragmentado pelas identificações projetivas, bastante primitivas e vorazes, na verdade definindo um padrão antropofágico para as relações do mercado erótico em que vivemos" (PRZEMYSLAW 1998, p.224).

Segundo o autor, nessa espécie de palco, as doenças sexualmente transmissíveis podem se desenvolver na compulsividade e promiscuidade: “O momento cultural já 
era catastrófico, e a aids veio conferir uma de suas notas mais trágicas" (p.225). Ele considera, entretanto, que o século XX foi o mais "relacional" que já houve, apesar do narcisismo e da cultura de sobrevivência, do mínimo eu (com LASCH, referido por ele).

Para PRZEMYSLAW, a aids trouxe um "choque narcísico" influenciando a ética dos tempos atuais. Trouxe, também, preocupações com o sexo seguro e considerações com o outro. Neste ponto, o autor assinala o apelo de LACAN para o Outro, com O maiúsculo, tendo um lugar fundante no psiquismo do sujeito. Possui uma função na formação dos ideais do ego, através dos problemas com que se defronta, permitindo uma reorganização ou amadurecimento do sujeito.

$\mathrm{O}$ autor ressalta o caráter de normalidade da polimorfia perversa desde as primeiras formulações psicanalíticas sobre a sexualidade. Quando articula perversão e compulsão considera que a patologia é sua sujeição aos instintos de morte, cuja força destrutiva pode aniquilar a estrutura do sujeito ou a do Outro.

Segundo o autor, o sistema imunológico é seletivo aos seus agentes invasores, havendo a suposição de uma certa capacidade de "pensar" da célula que possui defesas específicas para cada agressor: “... o sistema imunológico é um depositário da memória das lutas intercelulares da história do indivíduo. E é um sistema que aprende, seja naturalmente, seja induzido por vacinas" (PRZEMYSLAW 1998, p.228). O autor complementa com a hipótese de que, sendo a promiscuidade determinante do fenômeno, a pulsão de morte também o é, pois tende ao retorno da excitação ao nível mais baixo possível, mesmo que de forma auto-agressiva atinja o sistema imunológico. Está aí a base da suposição do desenvolvimento da doença auto-imune, segundo ele.

Pode-se considerar essa hipótese como de suma importância para o investimento das formulações psicanalíticas na prevenção de aids, através do fortalecimento das defesas do organismo no drible da pulsão de morte.

O autor finaliza dizendo que hoje se admite a prática sexual para fins de obtenção de prazer e não exclusivamente, com fins de reprodução. Entretanto, nem sempre se consegue esse intento, o que acarreta a busca desenfreada - pela norma atual permissiva - pelo Outro que obture a falta. $\mathrm{O}$ autor indaga: “... não estaria o Outro se instituindo como uma simulação do outro, pouco mais que uma projeção a 
serviço do gozo narcísico, e não teria a moral sexual que se sofisticar para conter mais um cinismo?" (PRZEMYSLAW 1998, p.229) (destaque do autor).

Sua questão refere-se ao risco de tomar identificações projetivas por verdadeiras relações com o Outro. E, como analista, pode-se interpretar as relações no nível intrapsíquico e interpsíquico, inclusive as relações da psique-soma. Não se pode excluir o sistema imunológico, apesar da tendência a ignorá-lo. Conclui: "Não há justificativa ética para a sonegação científica. Nossos clientes não estão precisando de estátuas. Estão precisando de práticos" (PRZEMYSLAW 1998, p.230).

Passa-se às considerações de outro autor sobre a psicoimunologia. PEREIRA (1994) objetiva refletir sobre as similaridades existentes entre os anticorpos, os genes e a mente, tendo como base de discussão a doença e o adoecer. Trata dos enigmas e modelos de funcionamento dos sistemas psíquico e imunológico, abordando os conceitos de relações objetais, pulsão de morte e os mecanismos de defesa.

$\mathrm{O}$ autor parte do pressuposto que existe uma competição entre Eros (sistema imunológico) e Thanatos (célula degenerada) no caso do câncer, diferenciando do caso da aids, em que a doença só se manifesta quando o material do retrovírus é incorporado ao patrimônio genético do portador substituindo-o (característica do retrovírus). Vejamos como o autor realiza a análise, mediante a sua advertência de correr o risco de apresentar um trabalho “... não conclusivo e complexo quer em Psicanálise quer em Imunologia” (PEREIRA 1994, p.59), almejando mostrar um caminho possivel que é o de se pensar sobre o enigma do ser humano, a vida e morte.

$\mathrm{O}$ autor afirma que os sistemas psíquico e imunológico encontram-se intimamente ligados. Sua hipótese é a de que é importante indagar sobre o estado mental e somático do paciente por ocasião do início da doença, que não é o mesmo quando a doença já está instalada. E é o “estado primeiro" o que dá “permissão" para que a doença se instale. Segundo ele, fica evidenciado no câncer, na aids e em qualquer doença de fundo genético que existe um espaço "vago" entre o psíquico e o biológico inatingível (destaques do autor).

PEREIRA (1994) desenvolve sua reflexão considerando a experiência biológica da vida como única, constituindo-se como uma constante luta entre Thanatos e Eros, que formam uma unidade sem igualdade.Traça um paralelo entre 
essa unidade (Thanatos e Eros) com as dualidades: soma + mente e analista + paciente. Dualidades essas, unidas por um funcionamento complexo que forma a unidade.

Afirma que a experiência psicanalítica é formada por uma união de dois cujo objetivo é a sobrevivência, mas cuja indissolubilidade (unidade) a transforma numa tarefa impossível, pois a ruptura é traumática e mortal. Por outro lado, a unidade somática está sempre em conjunção com as possibilidades mentais. É o corpo que viabiliza a mente, mas essa tem uma grande superioridade em relação ao seu parceiro, uma vez que suas respostas são muito mais rápidas, tanto no que se refere a mudanças quanto às relações transferenciais. Citando o exemplo do câncer: — “... a depressão é muito mais cancerígena do que quatro maços de cigarros por dia" (PEREIRA 1994, p.54), e a Teoria do Instinto de Morte de FREUD: “... a morte é um fenômeno interno, partindo do núcleo celular" (p.55) - , o autor aponta as descobertas atuais de que há genes responsáveis pela reprodução celular e que a membrana celular se torna permissível por um desarranjo em sua constituição.

$\mathrm{O}$ autor exime-se de apresentar certezas, por se tratarem de conjeturas que aliam seus conhecimentos psicanalíticos às pesquisas genéticas mais atuais. Considera que “... a interpretação, por acertada que seja, se for posterior ao processo orgânico instalado, dificilmente evitará ou produzirá a regressão de lesões já desenvolvidas onde houver PATRIMÔNIO GENÉTICO lesado" (PEREIRA 1994, p.55) (destaques do autor).

Com esse posicionamento, o autor enfatiza aspectos instintivos do ser humano que "escapam" ao poder da explicação das relações objetais, sem negar a influência de tais relações na gênese de algumas doenças ditas psicossomáticas. Assemelha, neste sentido, a forma de funcionamento do sistema imunológico à do sistema psíquico.

$\mathrm{O}$ artigo inclui ilustrações das mais recentes descobertas da medicina nas pesquisas genéticas e oncológicas e discrimina o caso da aids. $\mathrm{O}$ autor pergunta-se se a substituição do patrimônio genético do portador pelo retrovírus é fruto de uma falha das defesas ou uma "permissão". Acha que se deve conviver com ambas as possibilidades pela permissividade da membrana celular que fecha, mas que, também, abre. 
Diante da inatingibilidade da interpretação, o biológico tem que se haver sozinho, com suas defesas pulsionais. É nesse espaço onde se aloja a pulsão de morte. Soma-se a dificuldade da especificidade e singularidade de cada caso (não universalidade), como foi verificado por outros autores que colaboraram com seus achados no presente estudo (RUIZ, SANCHES, CIPRIANO, dentre outros).

A dualidade referida à dupla analista-analisando é estendida, aqui, para o próprio indivíduo consigo mesmo que, ao ser acometido pela doença imunológica se depara com o ódio de ser ele, e não o outro, o portador.

PEREIRA (1994) analisa, ainda, a relação entre o psicanalista consigo mesmo (quando é acometido da doença), com a doença e com o paciente, ressaltando o grande trabalho interno de lidar com as próprias emoções e com as disposições do paciente (a culpa, a piedade, a esperança, etc).

Considera que os estudiosos desta área têm muito pela frente, e que a psicoimunologia é um novo desafio que se apresenta à prática psicanalítica. $\mathrm{O}$ desafio, segundo o autor, é o entendimento do "mistério da vida”. “... a Unidade com Igualdade é a busca, embora nunca possível como meta a ser alcançada, diante das surpresas e azares da vida. (...) Essa meta seria a busca de um local e de um estado interno poucas vezes visitado pelo homem, a não ser de forma fugaz. Como diria Hélio Pellegrino: A condição humana jamais será curada" (PEREIRA 1994, p.59) (destaque do autor).

Encerrando sua reflexão, o autor afirma: “... temos mais problemas que soluções. O caminho continua o mesmo, ou seja, entender o que se passa ou se passou em várias vias: pela via do psicanalista e pela via do paciente; pela via do SOMA e pela via Mental. Tentamos introduzir uma outra via: a doença em si, com suas particularidades que a tornam um instrumento de Thanatos único. (...) precisaríamos nos ater a um fato de suma importância: há uma distância entre a interpretação e a linguagem do corpo, espaço ainda não atingido pelo psíquico ou pelas defesas corporais. Talvez aqui esteja a evidência das tendências thanáticas da pulsão de morte" (PEREIRA 1994, p.59-60).

Permite-se inserir nesse diálogo uma citação que vem caracterizar a importância da noção de pulsão de morte:

“... se Freud não houvesse inventado a pulsão de morte, por certo ficaríamos 
privados de uma representação trágica dos desafios históricos que a consciência moderna tem que enfrentar" (ROUDINESCO 2000, p.129). Enfim, a questão não se encerra, fica suspensa por ora para que o trajeto tenha prosseguimento.

Tomando, agora, o tema denominado Desenvolvimentos psicanalíticos, serão referidos alguns trabalhos. Não serão referidos todos os trabalhos que teriam pertinência, pois vários deles já foram assinalados anteriormente, no presente trabalho, quanto a aspectos relacionados a outros temas, e que também são refletidos a partir da teoria. O intuito é não tornar o texto fragmentado ou repetitivo.

TAVARES (1991), investigando o mito do complexo de Édipo, no episódio da Medusa, destaca as relações entre Perseu e as figuras masculinas e femininas que povoam a narrativa. Trata-se de uma reflexão metapsicológica, cujo interesse primordial é discutir a dinâmica psíquica do indivíduo constituído por uma estrutura perversa. Utiliza o mecanismo da recusa que impede a apropriação ou internalização da lei paterna. O indivíduo fica sujeito à ação da pulsão de morte, pois o seu ego dividido e frágil o deixa propenso a procedimentos destrutivos como a “... drogadição, infecção por aids, relacionamentos sadomasoquistas, e, às vezes, homicídio e suicídio" (TAVARES 1991, p.303). Não faz muito sentido entrar nos detalhes da análise feita pelo autor, pois o interesse pela mesma, no presente estudo, restringe-se ao que ela toca na questão da aids, já referida. Ademais, o autor considera a infecção como fruto de um funcionamento perverso, posicionamento que pode ser considerado controverso pelo que foi visto até aqui. Não há intenção de "fechar" com uma postura desse tipo, por ela fugir dos objetivos propostos neste trabalho e por não contribuir com um enfrentamento efetivo da epidemia. Cumpre ressaltar a importância e seriedade em relação à forma como o tema foi analisado por TAVARES, que pode auxiliar na compreensão psicanalítica do tema do complexo de Édipo, mas do tema da aids nem tanto.

COSTA (1992), por sua vez, traz contribuições muito importantes para a questão do homoerotismo que têm servido de referência teórica para vários estudos. Suas proposições foram, em parte, já apresentadas mais acima para ponderar sobre a consciência de risco dos sujeitos. Resta, entretanto, acrescentar a forma como ele lança mão da “... teoria do imaginário e do inconsciente estruturado como uma linguagem [que transforma a psicanálise em] análise dos discursos aparentes que 
exibem certas formas de expressão do desejo" (p.138-9). Em sua própria visão da psicanálise, o autor considera que, ao analisar as falas ou discursos manifestos, podese dar conta da maneira pela qual o sujeito estrutura sua imagem do eu ou sua autoimagem, e como isso entra em acordo com o psiquismo.

Foi dessa forma que analisou as respostas dos sujeitos homoeroticamente orientados diante da aids, a partir das quais considera importante continuar a dirigir ao grupo dos chamados "homossexuais" as informações sobre a prevenção, de forma melhorada e articulada com o combate ao preconceito. Na sua opinião, “... quanto mais os indivíduos têm condição de discutir publicamente o problema do homoerotismo, mais têm condição de optar por regras claras de definição da ïdentidade homoerótica e mais encontram suporte nessas regras para aceitar as limitações da vida sexual impostas pela aids" (COSTA 1992, p.191-2) (destaque do autor). Sem isso, as decisões dependem de cada um e, conseqüentemente, nem sempre podem beneficiar a coletividade.

BIRMAN (1994), sob o sugestivo título "A sexualidade entre o mal e as maledicências", discute como a aids inscreve a figura da morte novamente na experiência do gozo (conceito da teoria lacaniana), renovando antigos temores fundamentais constituídos no imaginário ocidental pelo Cristianismo, apresentandose [a morte] como o Outro que se interpõe no cenário do prazer, devorando a experiência erógena.

Propõe-se a fazer uma leitura crítica do remanejamento de forças, de um lado a ética da pós-modernidade formada pelas conquistas dos direitos sexuais e dos direitos às diferenças subjetivas incorporadas aos direitos sociais e, de outro lado, o evidente recuo neste campo e uma relativização das conquistas.

São incluídas algumas considerações do autor quanto à sua forma de avaliar a dinâmica que se estabelece na sociedade. Ele verifica a tentativa de se evitar o contato até mesmo com o anúncio da morte, como se isto pudesse atualizar o acontecimento da perda da vida. Isso porque, segundo ele, “... a figura da morte é a fonte inesgotável para a montagem de terroríficos espetáculos perversos" (BIRMAN 1994, p.110). O autor relembra que a morte como doença e epidemia são antigas desde a lepra e a peste, e retoma o discurso da medicina social e práticas de saúde pública a favor de uma estratégia de manutenção da vida e do espaço social, que 
autoriza “... uma política de exclusão social dos doentes e dos sujeitos que seriam potencialmente enfermos, pois se inserem nos denominados grupos de risco" (p.111).

BIRMAN diferencia a aids das clássicas doenças venéreas. Embora ambas estabeleçam relações entre a sexualidade e a morte, as últimas são conseqüências da volúpia sexual, mas fazem parte da norma sexual heterossexual não questionada, enquanto que na primeira, a morte é conseqüência do desejo sexual, da escolha sexual homossexual para a qual já há a penalidade do sujeito no imaginário social e psíquico (daquele que foge à norma). A aids explicita o pluralismo do desejo, com a constituição de outra norma sexual e a suspensão de qualquer interdição em face do desejo homossexual. “... com a aids a criminalização dos homossexuais pelo genocídio da humanidade e a sua medicalização massiva se coloca novamente em cena" (BIRMAN 1994, p.113).

Haveria que se indagar se o que está sendo colocado pelo autor como vigente naquele tempo, hoje faria o mesmo sentido, tendo em vista o aumento da infecção feminina pela categoria de exposição heterossexual. Teria que se interpretar de novo ou caberiam as mesmas formulações?

No prosseguimento de sua reflexão, BIRMAN já faz uma autorização nessa direção: “... a problemática da sexualidade é o fio condutor para a indagação de algumas das questões cruciais que a aids coloca na atualidade”. Ela coloca em jogo os destinos da sexualidade na cultura do ocidente neste final de século e, por se apresentar como uma epidemia e doença mortal, transcende o universo dos cuidados e da assistência médica, revelando alguns dos valores e a ética que subjazem à nossa tradição cultural. A aids deixa manifestos também os “... prazeres possíveis e direitos desejáveis (...) amores permitidos e (...) enlaces interditos" (BIRMAN 1994, p.114).

$\mathrm{O}$ autor relembra que o discurso freudiano e a psicanálise estão aí para dizer sobre a natureza do desejo e sobre a sua legitimidade, permitindo uma compreensão dos mesmos.

Da maneira como BIRMAN observa, a aids possibilita uma multiplicidade de leituras sobre o corpo, necessárias para se questionar os dispositivos sanitários aplicados nesse campo, para que se possam promover intervenções sob diferentes perspectivas garantindo sua adequação e eficácia.

E continua: "A sexualidade e o universo macabro constituído sobre a aids 
revelam de maneira eloqüente que o corpo não é apenas um suporte físico (...) como corpo representado o sujeito se constitui por diferentes estratégias lingüísticas, políticas e sociais, que fazem com que de um organismo biológico se produza um corpo erógeno" (BIRMAN 1994, p.114). É a erogeneidade que dá a enunciação do estatuto simbólico do corpo que estão em questão nos discursos sobre a aids.

A reflexão de BIRMAN expõe uma face do campo psicanalítico que permite uma travessia para o campo da saúde pública, passando-se a partir daqui a priorizar os fenômenos da coletividade, tendo como veículo a aids.

As conexões foram sendo elaboradas ao longo do percurso entre os diferentes trabalhos. Retomam-se algumas colocações dos autores e acrescentam-se outras, visando refletir sobre o Impacto do uso de um instrumental do plano individual para o plano coletivo.

Pensando menos sobre a questão particular do indivíduo com escolha objetal homossexual e mais sobre a sua inserção na sociedade onde são estabelecidos os laços sociais, inclui-se o texto de GIOVANETTI e ÉVORA (1997). As autoras propõem-se a refletir sobre as representações histórico-sociais que têm determinado o sentimento de perplexidade e culpa, em menor ou maior grau, dos infectados, moldando assim a identidade do "aidéticos". *

As autoras refletem sobre os temas sexualidade, morte e doença, considerando que, “... de acordo com as séries complementares freudianas, o surgimento ou agravamento de um desequilíbrio emocional mais manifesto poderia ter sido ocasionado por outros eventos de igual perniciosidade na vida desses indivíduos, não somente pela aids" (GIOVANETTI e ÉVORA 1997, p.128).

Elas observaram algumas regularidades através das entrevistas realizadas. Com relação à sexualidade, a primeira regularidade presente é o sofrimento que representa precisar esconder a condição de soropositivo para não ser obrigado a revelar a inclinação homoerótica socialmente desvalorizada, perpassando também a noção de que a moral sexual conservadora finalmente levou a melhor, e que as práticas individuais optadas livremente repentinamente foram proibidas. A pressão social vigente os faz crer que tal proibição se inscreveu em seus próprios corpos. $\mathrm{O}$

\footnotetext{
* Colocam um adendo a respeito do termo que caiu em desuso por ser politicamente incorreto, mas que continua sendo usado pela população em geral.
} 
indivíduo infectado pelo vírus HIV é “... efetivamente a morte que ele mesmo escolheu" (GIOVANETTI e ÉVORA 1997, p.132).

Muitos vivenciam a culpa pela infecção e sua ligação com a promiscuidade e homoerotismo - as autoras utilizam o desenvolvimento feito por COSTA (1992) sobre o tema, já mencionado no presente estudo - resultante da construção social da doença que, segundo as autoras, é um processo que deriva da medicalização do dia-adia. Em nome de manter e reproduzir a vida, a sexualidade torna-se de interesse público e instrumento de controle social. "A aids, exacerbando a tensão entre os interesses da coletividade na esfera da sexualidade (ligados à reprodução e seu controle) e os interesses individuais (ligados ao prazer), revela, mais claramente, os limites na área da sexualidade de tal modelo de normalização médica do social" (PAIVA citada por GIOVANETTI e ÉVORA, p.133).

Abordando o tema da morte, as autoras apontam que na contemporaneidade morrer passou a ser inaceitável, pois com os avanços da medicina aumenta-se a expectativa de vida. Com a aids, “... essa que se tornou o nome mesmo do inominável, [o portador] enfrenta um angustiante paradoxo: (...) é considerado socialmente morto para muitos (...) e, quando finalmente se aproxima a experiência tão temida, espera-se que abra mão do direito de exprimir tal terror, pois tal tensão emocional é incompatível com a regularidade da vida quotidiana (sic) familiar ou hospitalar...” (p.132-3). Ao contrário, quando o indivíduo resigna-se, é acusado de falta de fibra e de luta.

No cotidiano, existe uma falta de sustentação social no relacionamento entre pessoas do mesmo sexo que pode afetar até mesmo a possibilidade de tratamento da doença, na medida em que se tira a aids do lugar de doença grave e fatal para colocala num outro lugar que beira à maldição. Os mitos ainda estão aí, nocivamente, segundo as autoras, para propagar relações de objeto irracionais. Algumas decisões dos portadores passam pelo crivo destes mitos, dentre os quais à equiparação da aids com a morte.

GIOVANETTI e ÉVORA iniciaram o trabalho buscando uma peculiaridade psíquica que, através do referencial psicanalítico, dirigia-se para os modos de produção de sentidos gerados pelo desejo inconsciente, voltado para o estrato individual. Passaram a mirar o estrato social com o qual se interage constantemente 
no cotidiano, onde são experimentadas as ficções produtoras dos sentidos coletivos. Em seu papel de interlocutoras dos entrevistados as autoras evidenciaram que elas estavam representando o social. Era com esse lugar que a transferência operava, razão pela qual advertem a necessidade de levar em conta as resistências dos entrevistados. Ressaltam também o sofrimento dessas pessoas por viverem na clandestinidade, diante da inclinação homoerótica e da condição clínica associada à aids, mesmo que assintomática.

Para finalizar a discussão do tema do impacto do instrumental individual no coletivo, ROTHSTEIN (1997) faz uma analogia entre o "O mal-estar na civilização" (FREUD 1930) e a epidemia da aids, concebendo a doença como decorrente de inadequações de vida do indivíduo e as funções mentais como imunológicas (sendo defesas do homem contra doenças). Indaga se a aids seria uma forma de mal-estar na civilização atual.

O autor, ao traçar o paralelo com o texto de FREUD, constata sua atualidade, apesar de ter sido escrito décadas atrás. Considera que isso só foi possível porque o ser humano é dotado de paradoxos, e a acoplagem da questão da aids às idéias desenvolvidas deriva do caráter da pandemia só existir porque os seres humanos existem e se relacionam intimamente. Possuem instintos básicos que são satisfeitos através da busca imediata do prazer por cada um e pela coletividade. ROTHSTEIN recorda que os indivíduos estão dispostos nas grandes cidades em conglomerados, vivendo o drama da subsistência permeada pelas diferenças sociais. Pensando nisso, entende-se como a doença surgiu e se expandiu; inicialmente em alguns grupos “... que incomodavam [e] que expunham, com certo heroísmo, uma espécie de natureza mais crua de desejos incontroláveis que sofriam, naturalmente, recorrentes tentativas de coibição, por todos os que, hipocritamente, fingiam ser imunes a eles. Mas hoje, (...) temos uma doença infecciosa disseminada pelos cinco continentes e, portanto, globalizada” (ROTHSTEIN 1997, p.227).

$\mathrm{O}$ autor reflete que os comportamentos individuais - a favor ou contra a propagação do vírus - são conseqüentes da relação dos indivíduos com a civilização. Considera a doença não só do ponto de vista orgânico, mas também do ponto de vista do imaginário individual e coletivo no qual ela se inscreve. É uma enfermidade que questiona valores, conceitos e pré-conceitos e não tem cura até o 
momento. Resta oferecer o cuidado e a "continência" que envolvem o respeito pelas escolhas dos indivíduos, de desistência, aceitação e/ou medo, inerentes à proximidade da morte, pois, “... é tão insuportável uma dor que se sabe inextinguível...” (ROTHSTEIN 1997, p.228).

Quanto às formas de prevenção pelo sexo e pelo uso de drogas, o autor recorre mais uma vez a FREUD para explicar que os instintos que influenciam o humano e para os quais ele busca o prazer são poderosos, agindo diretamente sobre essas formas de infecção/prevenção. ROTHSTEIN compara a satisfação obtida pelos diferentes instintos. Indica que um instinto não domado pelo ego, ao ser satisfeito, produz um sentimento de felicidade muito maior do que um outro que já foi domado. Conclui que esse aspecto relaciona-se diretamente com a questão do uso do preservativo e o não compartilhamento de agulhas e seringas, formas de proteção preconizadas contra o vírus da aids. Em decorrência desse raciocínio, como controlar o impulso? Como promover a prevenção, se para isso é necessária a imposição de mais regras ao indivíduo, além das que a civilização já lhe impõe?

Percebe-se que a satisfação dos desejos fica ameaçada frente às mudanças que se tem que operar para a prevenção; porém, pode-se pensar em ganhos com essas mudanças, no sentido do indivíduo tomar para si a responsabilidade pelos seus atos e se desenvolver, psiquicamente, com essa atitude. De acordo com ROTHSTEIN (1997, p.230): “Temos desejos a satisfazer, temos que nos cuidar para realizá-los e somos parte de uma civilização que nos açoita a todo o momento, desprezando o que nos diz respeito, enquanto indivíduos, em prol de sua manutenção. Não é pouco".

Poder-se-ia acrescentar que, não é que seja pouco, e se completar com um "é demais!” O por quê desse acréscimo diz respeito à emergência de lembranças do início do presente trabalho, quando ainda se falava dos primeiros tempos na história da epidemia, com seus números e desenvolvimentos conceptuais, conjeturas e suposições, que tocam em algumas concordâncias e semelhanças de posicionamentos de autores de áreas nada comuns entre si. A conexão é direta entre esse último texto que fecha (mas não encerra) o diálogo entre os autores pesquisados - os psicanalistas, e que traz idéias condensadas de forma brilhante vindas de vários lugares, alguns deles certamente nunca visitados pelo autor. Remete à idéia "tresloucada" de que seria maravilhoso ter à mesma mesa de debate: COHN, MANN 
e col., ROTHSTEIN e FREUD. Isso nunca seria possível ao vivo e a cores, porém torna-se viável no papel:

ROTHSTEIN e FREUD acabaram de ter a oportunidade de se colocar. É a vez de MANN, seus colaboradores e COHN.

Inicia-se com MANN e col. que criam o conceito promissor de vulnerabilidade, essencial para se compreender a história da infecção do HIV/AIDS e para predizer o rumo da pandemia. Relembram-se as suas idéias. No nível biológico todos são vulneráveis à infecção pelo HIV. Ainda não foi descoberta a resistência inata a esse vírus, caso ela exista. Segundo os autores, o vírus requer condições específicas para que sua transmissão ocorra. Quando afirmam isso, os autores estão referindo-se a comportamentos, nos quais há que se envolver dois ou mais participantes para essa transmissão. Neste sentido, a necessidade de desenvolver abordagens mais sensíveis à grande diversidade de propriedades incorporadas ao fenômeno saúde-doença, vem ao encontro da noção de vulnerabilidade (MANN e col. 1992). Dentre essas propriedades, acrescenta-se as condições psíquicas dos indivíduos em sua lida com as exigências da civilização.

COHN, por sua vez, numa análise das dimensões sociais da aids, COHN (1997, p.46) já sugeriu: “... independentemente das características biológicas da doença, seu comportamento pandêmico na sociedade remete à complexidade da sua rede de transmissão, que tece sua trama numa imbricada interpenetração das esferas pública e privada da vida em sociedade". A autora ressaltou também que há formas de transmissão que dependem de ações do Estado (controle da qualidade do sangue, por exemplo) e ações que são de natureza privada (práticas escolhidas pelo indivíduo). Essas últimas, para serem enfrentadas pela saúde pública, implicam uma invasão do universo da esfera privada, o universo das preferências individuais. Segundo ela, trata-se de um desafio duplo: a) dificuldade de compreensão da esfera psicológica que determina as diversas preferências individuais, de se expor a práticas de risco (sexual ou de outra ordem) de contrair e propagar a doença, consciente ou inconscientemente; b) ao abordar práticas de risco de trabalhadores do sexo e usuários de drogas injetáveis, há que se transitar entre as esferas da legalidade e ilegalidade, dificultando uma ação social eficaz.

Como se aventou ainda há pouco, este é um dos méritos da aids: poder sentar à 
mesma mesa para dialogar os que estão envolvidos com ela, ainda que muitos já tenham nos abandonado.

Podem-se, assim, conciliar os diversos segmentos envolvidos na questão da aids. Tal tema também pode renovar e reestruturar, e isso pode ser evidenciado através da discussão do assunto em congressos e encontros onde se sentam juntos vários segmentos: médicos, profissionais do sexo, usuários de drogas ${ }^{*}$, etc. O saber torna-se de domínio público, socializado, pois todos estão implicados nesta realidade. A aids faz parte da vida, seja qual for a condição sorológica de cada indivíduo. Devese tomar cuidado para que ela não seja mais um instrumento de repressão dentre os que já existem, mas uma possibilidade de expor os conflitos e paradoxos da civilização para, então, poder trabalhá-los. Criar “...uma ética baseada em saúde, em cuidado, mas respeitando sempre a opção de cada um, mesmo que esta não seja, de um ponto de vista técnico ou filosófico, positiva ou construtiva" (ROTHSTEIN 1997, p.230) (destaque do autor).

Com esse intuito, é importante seguir o conselho de vários autores incluídos nesta pesquisa. Eles alertaram para a necessidade dos profissionais terem as suas questões pessoais trabalhadas e resolvidas (ou, ao menos, reconhecidas e discriminadas), para poderem lidar adequadamente com o tema da aids e com as pessoas que os procuram. Com isso evitariam invadir o espaço do paciente com as próprias questões e problemáticas e não se constituiriam como mais umas das imposições da civilização (CASSORLA, COSTA, SANCHES, dentre outros).

\footnotetext{
*Ministro da Saúde, como ocorreu no Fórum 2000, evento já referido anteriormente no presente estudo.
} 


\section{CONCLUSÕES}

A proposta de investigar o que existe na literatura brasileira de saúde pública e de psicanálise em torno do que está sendo pensado, teorizado e praticado sobre a aids vai chegando ao seu final. Procurou-se organizar o material encontrado articulando-o de forma a poder interpretar os trabalhos sobre a epidemia da aids e melhor compreendê-la sob o prisma da psicanálise para, com o conhecimento adquirido, viabilizar novos estudos e ações.

Salienta-se a utilidade que essa sistematização poderá trazer para o campo da pesquisa, inferência devida à própria fala dos autores pesquisados que ao iniciar seu levantamento bibliográfico não puderam dispor de material mais vasto.

Nesse sentido, MARQUES (1993) ressaltou que a revisão bibliográfica realizada por ela na BIREME e nas Bibliotecas do Hospital Emílio Ribas e do Centro de Referência e Treinamento de Aids, de 1986 a 1993, resultou na ausência de títulos relacionados à pesquisa psicanalítica e a aids, apesar de já haverem alguns nesta época, como foi mostrado no presente estudo.

De forma semelhante mas mais específica, SANT'ANNA (1996) fez um levantamento bibliográfico na Base de Dados PSYCLIT do período de 1982 a 1995. Por meio dessa pesquisa o autor obteve 638 artigos, dos quais apenas 9 tratavam de questões referentes à psicodinâmica dos portadores do HIV (incluindo os estudos em língua estrangeira), donde SANT'ANNA relevou que, para uma melhor compreensão da aids e da prática clínica, era necessário buscar mais conhecimentos junto ao portador do HIV.

Como era a intenção do presente estudo, o material de análise incluiu somente textos brasileiros e, portanto, dá uma noção do que está ocorrendo em nosso país, com as características próprias do setor saúde de apresentar carências, mas também de improvisar, criar e planejar soluções para os problemas da clientela, dos profissionais e dos serviços.

Utilizando-se da leitura "flutuante", meio proposto inicialmente para "escutar" os textos, foram elegendo-se formas de associá-los, e dar-lhes sentido através de uma linguagem compreensiva e elaborativa que possibilitasse a assimilação pelo leitor. Tal é o produto do trabalho: a constituição de um campo por onde transitam as 
projeções dos pesquisadores (os autores), através da construção de seus textos, reconstruídos sobre a nova estrutura projetada. A obra concretizada pretendeu não ser rígida, mas móvel e dinâmica, no sentido de mostrar a superfície mais externa e aparente, deixando vãos livres para que as suas bases pudessem ser recuperadas sempre que fosse necessário. $\mathrm{O}$ estado atual em que ela se encontra já dá mostras de ações que podem e estão sendo executadas para incrementar medidas preventivas que contribuam para a redução da vulnerabilidade dos sujeitos.

São as aspirações de diversos autores ao encerrarem seus textos, igualmente comungadas na presente conclusão. Muitos esperam que, com seu trabalho, tenham contribuído para a ampliação da discussão deste fenômeno, acrescentando à compreensão da aids a visão do inconsciente e do seu significado. Certamente a contribuição foi dada e reconhecida. Volta-se a alguns deles, nesse momento, no sentido de resgatar algumas de suas sugestões.

Com relação à comunicação do resultado do teste sorológico, CAVALLARI (1997) dá pistas para minimizar o impacto verificado nas conclusões de sua pesquisa que vão desde o tempo de espera que antecede o resultado até o durante e o depois. De maneira geral, a autora sugere que se dê mais suporte ao paciente, permitindo-lhe um tempo para expor suas emoções, elaborar a notícia, incluir a sua história e minimizar seu sofrimento, abrindo a possibilidade de que possa retornar ao serviço caso necessite de mais espaço. Segundo ela, isso auxilia o paciente no processo de elaboração da revelação diagnóstica, mas vai depender, também, da possibilidade que ele tem de narrar a própria história, o que ajuda também o profissional, para que não se sinta tão impotente. O compartilhamento pela equipe e o revezamento dos profissionais para comunicar o resultado cumprem a função de tornar a tarefa mais suportável.

Para SANCHES (1997a), diante da revelação do diagnóstico, o espaço privado do indivíduo torna-se público. O corpo médico toma conhecimento dele, assim como toda a sociedade. Há que se criar, neste momento, espaço para o ódio, a dor e outros sentimentos, todos ligados à identidade do portador, seus conflitos e desorganizações. "Repentinamente, o indivíduo não sabe mais quem é. A revelação do oculto contamina tudo e só resta uma certeza: sou aquilo que não deveria ser" (SANCHES 1997a, p.19) (destaque da autora). 
Diante de um sujeito abalado por um diagnóstico de sorologia positiva para o HIV, a equipe deve funcionar dando suporte e apoio. Porém, para se trabalhar em equipe é necessário que haja uma sintonia entre os profissionais quanto aos objetivos e técnicas, e se procedam a reuniões periódicas visando trocas de dúvidas, angústias e de conhecimentos adquiridos. O exame dos próprios sentimentos também é recomendado. Um profissional com fobia ao homossexualismo deve evitar se especializar em aids (CASSORLA 1991). O preconceito em relação à homossexualidade foi considerado por alguns autores um dos focos de resistência ao atendimento do doente de aids pelas equipes (COSTA e MELLO FILHO 1987, 1988). Portanto, não só os familiares, parceiros e amigos do paciente devem procurar constituir um ambiente favorável, ele é extensivo também aos cuidadores, médicos e outros profissionais de saúde, além dos grupos de auto-ajuda (SANCHES 1997).

Vale a pena refletir, a partir desses estudos, no preparo dessas pessoas, subsidiando-as não só com informações adequadas, mas também cuidando para que elas possam lidar com as próprias emoções e sentimentos, para que possam manter sua saúde mental, sua dignidade e seu valor na função que desempenham. Os profissionais precisam ser incluídos na escuta.

No que tange à consciência de risco, uma das conclusões do trabalho de KLOURI (1992) é que a aids só passou a representar uma ameaça concreta após a infecção dos seus entrevistados. Antes disso, a aids era mais um dos elementos negados como sendo um risco à vida dos drogaditos mediante o seu funcionamento interno. A autora ressalta que esses achados deveriam constar da agenda de planejamento de programas de prevenção para esse público-alvo, levando em conta a dinâmica psíquica por ela descrita.

A aids contribuiu para o desenvolvimento de uma abordagem médica que não pode se restringir ao fato biológico — os autores atestaram. Para cuidar do seu paciente, os médicos, com o saber acumulado ao longo dos anos da epidemia, devem levar em conta, também, as dimensões sociais e emocionais do indivíduo e da sociedade, na medida em que foram essas as responsáveis pela expansão do vírus HIV. Com isso, há uma melhora da qualidade de vida das pessoas vivendo com HIV/AIDS, tanto no plano individual - com os significados que a existência passa a ter - quanto no social, com a cooperação das pessoas e das instituições no 
desenvolvimento de pesquisas de vacinas, medicamentos e melhor cuidado.

MELLO FILHO (1992) expõe sua questão/constatação de que houve a necessidade de uma doença como a aids para que as pessoas pudessem tomar consciência das múltiplas verdades sobre a sexualidade humana, sobre as práticas de saúde (como o problema das transfusões), sobre a realidade dos tóxicos e sobre o problema das viroses que de várias formas vem extirpando parte de suas existências. Pode-se adicionar à fala do autor o alto custo dessa constatação: muita dor, impotência e morte.

No início da epidemia muito se dizia sobre a morte. Atualmente, ao transcorrer quase duas décadas do seu início, já parece ser aceito que a morte faz parte da vida, pois o indivíduo infectado obriga a convivência com essa idéia.

VASCONCELLOS (1992), em sua visão psicossomática da doença, aponta para o fato de que a aids requer, para sua desmistificação, que se aceite sem pavor a morte que ela provoca. Isto se dará através da superação do preconceito social e do próprio preconceito (do profissional). Segundo esse autor, os psicoterapeutas necessitam conscientizarem-se do seu impulso de onipotência e dos seus limites como profissionais e como pessoas, para entender que não se salva ninguém da morte. Além disso, VASCONCELLOS considera que os profissionais devem compreender que todo ser humano é o único autor de sua morte, já que ela se processa através da dinâmica inconsciente de cada um. Segundo ele essa é uma fonte de energia que não se esgota nunca, constituída pelo próprio inconsciente, com a força que advém da luta pulsional.

QUEIROZ (1992) constata a importância de que o psicoterapeuta só deve se comprometer com o atendimento se estiver disposto a acompanhar os pacientes em possíveis circunstâncias especiais, podendo até abandonar os habituais preceitos éticos (ligados aos procedimentos médicos convencionais) e de setting para atendêlos. O desafio para o profissional está colocado, pois ele agora sai do lugar seguro e conhecido e tem que acompanhar a demanda do paciente. Hoje, oito anos depois desse texto ter sido escrito, são comuns os atendimentos fora do setting que provaram ser possíveis e adequados em vários contextos, dentre eles, o contexto constituído pela aids. Estão aí instituídos, funcionando e tendo êxito, os programas de atendimento domiciliar e, até mesmo, nos leitos hospitalares. 
Em se tratando das conclusões a que se chega, a aids fez tremer, mobilizou, tirou do lugar, mas, mais importante do que tudo transformou, aglutinou e juntou. Não foi uma dádiva, pois nada que seja tão mortal pode ser considerado como tal. Ela gerou inseguranças, expiou culpas, fez dizer coisas indizíveis, mas favoreceu um reconhecimento do si mesmo e do outro. É reconhecimento de que o ser humano é dotado de forças conflitivas de vida e de morte e de que deve lutar para sobreviver o tempo todo independente de que vírus tenha, e de que atitudes, comportamentos e crenças eleja. Como ele consegue isso, vai ser determinado pela forma como ele foi e vai sendo constituído ao longo da vida e dos laços que vai estabelecendo através de suas identificações. E foram elas, as identificações, as responsáveis pela possibilidade de se encontrar mais concordâncias que divergências no trabalho que ora se realiza. Por vezes tem-se até a sensação de mesmice, pela repetição de temas e opiniões. O importante é que há um saber sendo consolidado e em evolução no campo investigado.

Já caminhando para o encerramento do presente estudo, é necessário que se proponham novos passos. Um primeiro passo, que é mais uma sugestão decorrente de um incômodo assinalado mais atrás, é que se aposente a expressão "morte anunciada", como se propôs aposentar anteriormente os "grupos de risco" e o termo "aidético". Pois, são novos os tempos de aids (parafraseando o título do livro de PAIVA 1992). "A mortalidade por aids caiu em São Paulo", dizia a reportagem de um jornal de grande circulação ${ }^{*}$. Antes que o jornal, disseram as estatísticas de saúde: em São Paulo, os óbitos diminuíram em 53,6\% no ano de 1999. (COORDENAÇÃO NACIONAL DE DST/AIDS 2000). Notícia animadora? Certamente! As pessoas com HIV/AIDS estão vivendo mais em decorrência da implementação dos novos tratamentos com drogas de última geração, com universalidade de cobertura no Brasil. Assim a morte não precisa mais ser anunciada junto com o diagnóstico HIV positivo. Em conseqüência, não se deveria mais chamar o HIV/AIDS de objeto mortifero. Afinal, medidas simples como essa podem ser geradoras de um certo espaço psíquico favorável a se pensar e criar soluções, e não a gerar o pânico que vai paralisar e estagnar posições, impedindo ações produtivas e criativas. Não é deixando de usar as palavras que se mudam as atitudes e enfoques, 
entretanto, é um começo possível para tentar a mudança.

Apesar da queda da mortalidade, a aids continua seu curso, atingindo agora as pequenas localidades e as pessoas sem acesso à informação, o que as torna mais vulneráveis, sem excluir o aumento da pobreza e diminuição da qualidade de vida da população brasileira. Esse é um desafio e um segundo passo lançado a todos — aos profissionais de saúde, à sociedade em geral e aos próprios indivíduos infectados: fazer um trabalho de alargamento social junto às famílias, às empresas, às escolas, às organizações religiosas para abranger um maior número de pessoas e aumentar a informação e a prevenção. A exclusão social é algo que precisa ser riscado do mapa social, mas não à custa de se adquirir aids para sentir-se assistido com qualidade, dando-se conta de que "Ainda bem que tenho aids..." como foi evidenciado no trabalho citado de BARRERO (2000). Uma percepção como essa quase chega a considerar o indivíduo soropositivo ou doente de aids como um privilegiado, o que é uma inverdade que pode acabar minando as práticas preventivas.

Como um terceiro passo - talvez o mais complicado e complexo - é conveniente refletir sobre a necessidade de uma investigação oriunda de uma possível lacuna na produção literária brasileira em torno das pesquisas envolvendo aids e psicanálise, apontada por MOREIRA (1997) e inserida na discussão no presente estudo. Trata-se de algo supostamente da ordem da dinâmica das pulsões que habitam o psiquismo, com suas devidas ligações com o somático. Como foi assinalado, indaga-se agora: o que leva o ser humano a "buscar ativamente" e inconscientemente (ou não) a infecção por um vírus como o HIV? A resposta a essa indagação inquietante está além dos conhecimentos atuais. Retomam-se alguns trabalhos que abordam a questão da prevenção, com o intuito de compreender como isso tem sido tratado. Não ter consciência do risco parece ser um dos aspectos relacionados à não prevenção da aids e ao não uso do preservativo. SANCHES (1997a) considera que isso pode ser efeito do funcionamento do psiquismo humano que, sob a ação da angústia, é irracional. Não pensar no perigo para fugir do que é assustador é o que deixa o sujeito mais vulnerável. Pelo contrário, admitir a ameaça da aids pode deixar o sujeito em melhores condições para enfrentá-la, pois pensará a respeito apercebendo-se do perigo. "Não se pode negar que a aids é um risco, mas se

*Folha de São Paulo, 20/01/01, caderno Cotidiano. 
esse for visto como algo a ser enfrentado, aumenta a probabilidade de resistência" (SANCHES 1997a, p.131). Diminui, portanto, a vulnerabilidade. A autora procura identificar como isso ocorre em relação ao gênero.

No caso das mulheres, cuja via de transmissão principal é a sexual, a autora descreve o mecanismo que as impede de sugerir o uso do preservativo ao seu parceiro, através do qual, “... idéias que geram angústia tendem a ser evitadas. FREUD mostrava que o psiquismo humano procura diminuir tensão. Quando esta é gerada externamente, podemos fugir. Mas, quando vem de dentro, é preciso recorrer a recursos psíquicos como os mecanismos de defesa. Atacar a capacidade de pensar é um dos mais comuns. A pessoa emburrece, de uma forma geral ou específica. É um recurso comum na vida de todos nós - não quero nem pensar nisso.... Pensar é uma forma de entrar em contato com o objeto. Quando o contato gera angústia, fica impossível pensar. Não são muitas as mulheres que têm coragem de dizer não ao desejo próprio e do outro e, em nome da racionalidade, colocar em risco o relacionamento" (SANCHES 1997a, p.132) (destaques da autora). Isso já tem sido pensado, sem muito sucesso, nas propostas preventivas, mas tem que ser levado em conta sempre, com novas formas de abordagens que sejam mais eficazes para gerar nas mulheres atitudes de proteção à saúde. A atitude racional, neste caso, seria a negação do ato sexual sem proteção. O risco primordial não é o da perda do relacionamento afetivo, mas o da perda da saúde. As mulheres, no entanto, quando apaixonadas, mantém o risco de infecção à distância.

Os homens, por sua vez, segundo a autora, lidam com fantasias ligadas à aids, à homossexualidade, à perda da potência e do prazer ligados ao preservativo, que os impede de usar de forma sistemática esse modo de prevenção. "Numa sociedade marcada pelo narcisismo, perder a ereção representa uma ferida na auto-estima" (SANCHES 1997a, p.133). Além disso, a autora aponta que o ser humano, inconscientemente, considera-se imortal, nada o atingirá. Então, para que se proteger? $\mathrm{O}$ uso do preservativo poderia funcionar como um ataque à onipotência e à imortalidade sendo, portanto, ignorado.

Por outro lado, para SANCHES (1997a), faz parte do psiquismo a pulsão de morte, que, ao contrário de negar a morte, vai em direção a ela. E isso, para a autora, é tanto mais freqüente quanto mais o psiquismo está desorganizado. A destrutividade 
remete a si mesmo, mas também ao outro. Isso é mostrado claramente em um dos depoimentos do livro analisado, cujo entrevistado relata suas saídas, muitas vezes procurando a própria reinfecção e a de seus semelhantes.

Quanto aos homens casados bissexuais com dificuldade de assumir sua homossexualidade para não destruir a imagem construída de si próprios, o uso do preservativo pode significar colocar-se frente a frente com esse lado oculto. Coisa da qual se esquivam. Assim, atacam (inconscientemente) a si mesmos, à esposa e à prole, atitude análoga à que foi observada por COSTA (1992) — relatado no item 5.2.2 do presente estudo - quanto às relações entre consciência da identidade homossexual e atitudes de prevenção diante da aids. Analisando kleinianamente, SANCHES sugere que a inveja que o homem tem da mulher gerar filhos, em contrapartida à inveja do pênis pela mulher, acrescida da ascensão da mulher que cada vez ganha mais poder na sociedade, pode representar uma ameaça para o homem. A figura feminina pode se tornar ameaçadora, apesar de desejada. "E tudo o que ameaça é objeto de ataque...", reflete SANCHES (1997a, p.136). O indivíduo, não assumindo sua bissexualidade, pode vivenciar a culpa consciente ou inconscientemente, e ficar sujeito à infecção pelo não enfrentamento e não proteção contra o HIV.

Com base nesses trabalhos, pode-se pensar na questão da vulnerabilidade no plano da irracionalidade humana de se comprazer com o que envolve um certo risco. O ser humano parece ter intrinsecamente desenvolvido essa necessidade. Um caminho de investigação promissor no terreno da epidemia de aids, ainda não percorrido, é o que congrega conceitos psicanalíticos como a teoria das pulsões, o narcisismo, o ato falho e os mecanismos que o psiquismo utiliza para subverter a consciência com as estratégias de prevenção. As campanhas não pressupõem esses aspectos e dão prioridade para as informações endereçadas à ordem da consciência. O direcionamento a grupos sociais específicos é um caminho para essa aproximação, e isso já vem sendo praticado por alguns setores com resultados positivos. Por exemplo: as metodologias de redução de danos, utilizadas principalmente nos trabalhos com os usuários de drogas injetáveis, produziram uma mudança no padrão de infecção por essa via, observando-se um decréscimo de $18 \%$ no número de casos (COORDENAÇÃO NACIONAL DE DST E AIDS 2000). 
Não se trata de instituir novamente os chamados "grupos de risco", mas de aplicar aos programas de prevenção, que focalizam principalmente mudanças de atitudes e práticas (comportamentos), uma característica mais singular. Entende-se que quando se focalizam populações a serem informadas e orientadas, volta-se mais para a dimensão coletiva ou de massa, mas essa é formada por pessoas: mulheres, adolescentes de várias camadas sociais, homens, profissionais do sexo, etc, cada qual com a própria subjetividade. O desafio parece ser o de atingir a coletividade exposta ao vírus da aids que são todos os seres humanos e, ao mesmo tempo, o seu funcionamento psíquico, que é o que lhes confere a imunidade ou, pelo contrário, a vulnerabilidade. É um passo fundamental e instigante a ser pensado, pois não contempla a questão da informação conscientemente adquirida apenas. Insere, valoriza e particulariza a subjetividade dos indivíduos na construção dos laços sociais que imantam a adoção ou não das práticas de prevenção.

Há muito que se refletir nessa área. A sistematização do conhecimento construído no Brasil, que se concretiza através dos relatos e desenvolvimentos de estudos aqui inseridos, disponibiliza recursos teórico-práticos para implementar novos programas de prevenção que contemplem as formas pelas quais o ser humano lida com os seus desejos e proibições. $\mathrm{O}$ inconsciente, produtor da irracionalidade do homem, tornou-se menos desconhecido no que se refere à aids, embora o estudo evidencie carências de desenvolvimentos psicanalíticos mais aprofundados no campo da prevenção. Os mecanismos que o inconsciente utiliza para que o seu tutor seja ludibriado e as regras de proteção à saúde deixem de ser colocadas em prática estão menos obscuros. A dinâmica do funcionamento psíquico em torno da questão da aids foi enfocada sob vários aspectos, bem como as formas como o organismo adoece a partir desse funcionamento. O estado do conhecimento obtido por seres humanos lidando com seus semelhantes está aí à espera de utilização em benefício de outros seres humanos, tanto no plano individual como no coletivo.

Sem deixar de levar em conta as associações inconscientes que as palavras promovem, relembra-se da indagação: "saúde pública e psicanálise, como é possível?" O trabalho final está aí para que responder ele mesmo... E com a ajuda de

\footnotetext{
* Indagação feita pelo Prof. Dr. José Ricardo de Carvalho Mesquita Ayres a partir do título do presente estudo (AYRES 1999 out 21, comunicação pessoal).
} 
um dos autores envolvidos nesse "escândalo": “... se aquilo que está escrito é eterno, e permanece depois de décadas de profundas transformações sociais, que importava que fossem outras as palavras? No fundo, seu significado seria sempre um e o mesmo: o humano e suas conseqüências; o efêmero da vida e a concretude da morte; o invencível do tempo e a placidez da contemplação; a saúde idealizada e a doença oculta. Não, não devia permitir à escrita que pudesse ser o registro da vida e sua eterna dinâmica, sua busca perene de equilíbrio, sua constante necessidade de adaptação sem nenhum preparo anterior" (ROTHSTEIN 1997, p.211).

Enfim, a palavra é tudo do que dispomos. As possibilidades de articular os campos de saber advêm dela. Sempre é possível extrair lições e aprender com ela. É ela que permite compreender situações, experiências e sentimentos não vividos, mas contados por quem os viveu. Os discursos estão aí para comprovar. Deslocar para outro lugar, dar mais importância a um aspecto do que a outro, incluir o que não constava, dota o texto de uma lógica particular, mas sempre acessível a quem se dispõe a compreendê-la.

Saúde pública e psicanálise? Não são ambas interpretação com vistas à compreensão do fenômeno humano? Então, articular e compartilhar os saberes de uma e de outra sempre é possível, ainda mais em se tratando do tema da aids que exige parcerias. O caminho está aberto e os trabalhos o confirmam. 


\section{BIBLIOGRAFIA}

\section{Fontes Primárias de Pesquisa}

\section{7}

1. Costa LPM, Mello Filho J de. Assistência psicológica ao paciente com aids. Informação Psiquiátrica. 1987; 6(2): 41-46.

\section{8}

2. Costa LPM, Mello Filho J de. Atendimento psicoterápico em um caso de aids. Informação Psiquiátrica. 1988; 7(1): 20-25.

1989

3. Costa LPM, Lima CQ, Mello J de. Grupoterapia com pacientes HIV positivos (aids). Informação Psiquiátrica. 1989; 8(3): 97-103.

\section{1}

4. Caleiro Costa M de L. Aids: vida e morte em nossas vidas. Revista Percurso. 1991; 7(2): 41-3.

5. Cassorla RMS. Lidando com aids: uma experiência de supervisão de equipe multiprofissional. In: Cassorla RMS (coord.). Da morte: estudos brasileiros. Campinas: Papirus; 1991. p.231-41.

6. Tavares IM. Perseu - O mito e o complexo: uma variante do complexo de Édipo. Revista Brasileira de Psicanálise. 1991; 25(2): 303-16.

\section{2}

7. Costa JF. A inocência e o vício: estudos sobre o homoerotismo. Rio de Janeiro: Relume- Dumará; 1992. O homoerotismo diante da aids; p.127-95.

8. Eksterman VF, Procaci ACM, Fairclough LFO, Mello MPF, Rocha PC. Hemofilia e aids. In: Mello J de e col. Psicossomática hoje. Porto Alegre: Artes Médicas; 1992. p.325-33.

9. Ferreira CV de L. Conversando com o paciente HIV positivo: um estudo clínico. Campinas; 1992. [Tese de Doutorado - Faculdade de Ciências Médicas da UNICAMP]. 
10. Klouri C. Drogadição e aids: vivendo entre duas mortes. São Paulo; 1992. [Dissertação de Mestrado - Programa de Pós-graduação em Psicologia Clínica da PUC-SP]

11. Mautner AV. Vida e morte. In: Paiva, V (org.). Em tempos de aids: viva a vida: sexo seguro, prevenção, drogas, adolescentes, mulheres, apoio psicológico aos portadores. São Paulo: Summus; 1992. p.19-22.

12. Mello J de. Aids: o doente, o médico e psicoterapeuta. In: Mello J de e col. Psicossomática hoje. Porto Alegre: Artes Médicas; 1992. p.299-312.

13. Queiroz A. Aids: aspectos psicossomáticos. In: Mello J de e col. Psicossomática hoje. Porto Alegre: Artes Médicas; 1992. p.313-9.

14. Souza AND de. Grupo de reflexão multiprofissional em aids: uma estratégia em psicologia médica. In: Mello J de e col. Psicossomática hoje. Porto Alegre: Artes Médicas; 1992. p.320-4.

15. Vasconcellos EG. Aids e a morte psicossomática. In: Paiva, V (org.). Em tempos de aids: viva a vida: sexo seguro, prevenção, drogas, adolescentes, mulheres, apoio psicológico aos portadores. São Paulo: Summus; 1992. p.327.

1993

16. Dias EAC. O profissional de saúde mental frente à realidade aids: algumas considerações. Revista de Psicologia Hospitalar do Hospital das Clínicas de São Paulo. 1993; 3(1): 10-3.

17. Klouri C. Vivendo entre duas mortes: Drogadição e aids. Revista de Psicologia Hospitalar do Hospital das Clínicas de São Paulo. 1993; 3(1): 4-9.

18. Marques MIB. No teatro da vida o espectro da morte. São Paulo; 1993. [Tese de Doutorado - Programa de Pós-graduação em Psicologia Clínica da PUC-SP]

\section{4}

19. Birman J. A sexualidade entre o mal e as maledicências. In: Loyola MA (org.). Aids e sexualidades. Rio de Janeiro: Relume-Dumará/ UERJ, 1994. p.109-15.

20. Costa $\mathrm{MC}$ de J. Crianças com aids: a representação mental da doença. São Paulo; 1994. [Trabalho de Conclusão de Curso - Faculdade de Psicologia da PUC-SP] 
21. Cromberg RU. O fantasma do fim da história e a positividade do princípio feminino. Psicologia USP. 1994; 5(1/2):197-219.

22. Ferreira CVL. Aids e vida: um estudo clínico-psicanalítico com pacientes HIV. São Paulo: Lemos; 1994a. O paciente diante da aids e da morte; p.53-8.

23. Ferreira CVL. Aids e vida: um estudo clínico-psicanalítico com pacientes HIV. São Paulo: Lemos; 1994b.Aspectos psicodinâmicos da AUDS; p.59-62.

24. Pereira CAG. Unidade sem igualdade: caminhos da permissão. Revista Brasileira de Psicanálise. 1994; 28(1): 51-60.

\section{5}

25. Klouri C. Paciente terminal: análise possível-impossível, terminávelinterminável? Boletim de Novidades Pulsional. 1995; 80: 53-54.

\section{6}

26. Dias EC, Pessoa Labaki ME, Daspett C, Farias KQ. Avaliação das vicissitudes do atendimento de pacientes $\mathrm{HIV}^{+}$em psicoterapia de grupo. Revista Insight. 1996; AnoVI: 63: 16-20.

27. Pessoa Labaki ME. Aids: uma clínica da indagação. In: Cadernos de Subjetividade. $1996 ;$ 4(1/2): 153-61.

28. Rodrigues AM. O hiato entre conhecimento sobre as vias de transmissão e as práticas de prevenção da aids entre estudantes da USP: a atuação das ideologias de defesa. Psicologia USP. 1996; 7(1/2): 51-71.

\section{7}

29. Abduch M. Aids: Discursos de vida diante da morte - Estudo de mulheres portadoras do HIV, sintomáticas e assintomáticas. São Paulo; 1997. [Tese de Doutorado - Área de Concentração: Psicologia Clínica - Instituto de Psicologia da USP].

30. Cavallari CD. O impacto da comunicação do diagnóstico HIV positivo: a ruptura de campo diante da soropositividade. São Paulo; 1997. [Dissertação de Mestrado - Programa de Pós-graduação em Psicologia Clínica da PUC-SP].

31. Colóquio sobre aids; 1996 nov 14; São Paulo, Brasil. São Paulo: Cadernos de Subjetividade. 1997 ; 5(1): 183-204.

32. Giovanetti A, Évora I. A aids como construção social: uma triste metáfora. 
Revista USP. 1997; 33 (Dossiê Aids): 127-35.

33. Meiches MP.Uma metáfora possível da morte? Revista USP. 1997; 33 (Dossiê Aids): 117-24.

34. Moreira ACG. Melancolia e aids: da urgência da escuta do sintoma. Boletim de Novidades Pulsional. 1997; 93: 23-36.

35. Nosek L. Psicanálise e arte: Leonilson - Uma reflexão. IDE - Revista da Sociedade de Psicanálise de São Paulo. 1997; (30): 54-60.

36. Rothstein W. Aids: o mal... Está na civilização? In: Ferraz FC, Volich RM (org.). Psicossomática: psicossomática psicanalítica. São Paulo: Casa do Psicólogo; 1997. p.209-31.

37. Sanches RM. Escolhi a vida: desafios da aids mental. São Paulo: Olho d'Água; 1997.

38. Sanches RM. A relação médico-paciente sob o signo da aids. Revista USP. 1997; 33 (Dossiê Aids): 47-55.

\section{8}

39. Azevedo RCS de. Segunda fala. In: Jornada Psicanálise e Aids; 1997 jun 28; Campinas, São Paulo. Campinas: Escola Lacaniana de psicanálise de Campinas; 1998, p.9-15.

40. Barbosa LM. Terceira fala. In: Jornada Psicanálise e Aids; 1997 jun 28; Campinas, São Paulo. Campinas: Escola Lacaniana de psicanálise de Campinas; 1998, p.16-8.

41. Dias MM. Primeira fala. In: Jornada Psicanálise e Aids; 1997 jun 28; Campinas, São Paulo. Campinas: Escola Lacaniana de psicanálise de Campinas; 1998, p.2-8.

42. Lemos MTG de. Quarta fala. In: Jornada Psicanálise e Aids; 1997 jun 28; Campinas, São Paulo. Campinas: Escola Lacaniana de psicanálise de Campinas; 1998, p.19-22.

43. Moreira ACG. Eros, melancolia, aids: sobre alguns problemas da clínica contemporânea. Correio da APPOA - Associação Psicanalítica de Porto Alegre. 1998; 63: 24-31.

44. Pessoa Labaki ME. A situação de desamparo e a aids. Correio da APPOA Associação Psicanalítica de Porto Alegre. 1998; 63: 32-8. 
45. Przemyslaw RP.Sodoma e a estátua de sal atual / Sexualidade na era da aids. In: Graña RB (org.). Homossexualidade: formulações psicanalíticas atuais. Porto Alegre: Artes Médicas, 1998. p.217-30.

46. Sanches RM. A aids numa cultura de falsos selves. Revista Latinoamericana de Psicopatologia Fundamental. 1998; 1(2): 107-22.

\section{9}

47. Cipriano FL. Dinâmica das propriedades da sexualidade de 09 pacientes HIV-soropositivos em dois anos de investigação. São Paulo; 1999. [Dissertação de Mestrado - Área de Concentração: Psicologia Social e do Trabalho - Instituto de Psicologia da USP]

48. Pessoa Labaki ME. A situação de desamparo e aids. Pulsional - Revista de Psicanálise. 1999; 119: 17-27.

49. Ruiz J dos S. A Aids e suas representações: possibilidades de elaboração. São Paulo; 1999. [Dissertação de Mestrado - Programa de Pós-graduação em Psicologia Clínica da PUC-SP].

\section{0}

50. Sanches RM. Da sobrevivência à existência: a ressignificação da vida diante da aids. São Paulo; 2000. [Tese de Doutorado - Programa de Pós-graduação em Psicologia Clínica da PUC-SP]. 


\section{REFERÊNCIAS BIBLIOGRÁFICAS}

1. Adorno RCF e Castro AL. O exercício da sensibilidade: pesquisa qualitativa e saúde como qualidade. Saúde e Sociedade 1994; 3(2): 172-185.

2. Alexander F. (1952) Medicina psicossomática: seus princípios e aplicações. Trad. Célia Beatriz Fishmann. Porto Alegre: Artes Médicas; 1989.

3. Alvarenga A. A saúde pública como campo de investigação interdisciplinar e a questão metodológica. Saúde e Sociedade 1994; 3(2): 22-41.

4. Ávila LA. Doenças do corpo e da alma: investigação psicossomática psicanalítica. São Paulo; 1995. [Tese de Doutorado - Instituto de Psicologia da USP].

5. Ayres JRCM. Epidemiologia e emancipação. São Paulo-Rio de Janeiro: HUCITEC/ABRASCO; 1995a. A epidemiologia e o desafio da saúde coletiva; p. $25-31$.

6. Ayres JRCM. Epidemiologia e emancipação. São Paulo-Rio de Janeiro: HUCITEC/ABRASCO; 1995b. Para interpretar a epidemiologia: construindo uma perspectiva epistemológica; p.33-50.

7. Ayres JRCM, França Junior, I, Calazans, GJ. Aids, vulnerabilidade e prevenção. Saúde Reprodutiva em Tempos de Aids. Rio de janeiro: ABIA/Programa de Estudos e Pesquisa em Gênero, Sexualidade e Saúde IMS/UERJ; 1997.

8. Bardin L. Análise de conteúdo. Trad. Luis Antero Lopes, Augusto Pinheiro. Lisboa: Edições 70; 1995.

9. Barrero CEA. HIV and social exclusion. Examining the meaning of the state and NGOS' responses to the brasilian children's epidemic. In: I Fórum e II Conferência de Cooperação Técnica Horizontal da América Latina e do Caribe em HIV/AIDS e DST; 2000 nov 6-11; Rio de Janeiro, Brasil. Brasília; 2000. p.840. 
10. Beeker C, Guenther-Grey C, Raj, A. Community empowerment paradigm drift and the primary prevention of HIV/AIDS. Soc Sci Med 1998; 46(7): 831-42.

11. Bernstein RJ. Perfiles filosoficos. México, DF: Siglo Veintiuno, 1991. ¿Cúal es la diferencia que marca una diferencia? Gadamer, Habermas y Rorty; p.72-110.

12. Birman J. Psicanálise, ciência e cultura. Jorge Zahar Editor; 1994.

13. Boletim Epidemiológico - Aids. Ministério da saúde - Coordenação Nacional de DST/AIDS. Brasília 2000a; Ano XIII, Nº 1. <URL:http://www.aids.gov.br/> [2001 jan 27]

14. Boletim Epidemiológico - Aids. Ministério da saúde - Coordenação Nacional de DST/AIDS. Brasília 2000b; Ano XIII, N² 2. <URL:http://www.aids.gov.br/> [2001 jun 6]

15. Boletim Epidemiológico de Aids. Programa Municipal de DST/Aids. São Paulo 1997a; Ano I, No 1.

16. Boletim Epidemiológico de Aids. Programa Municipal de DST/AIDS. São Paulo 1997b; Ano I, No 2.

17. Boletim Epidemiológico de Aids. Programa Municipal de DST/AIDS. São Paulo. 1998; Ano II, No 4.

18. Breilh J. Epidemiologia: economia, política e saúde. São Paulo: UNESP/HUCITEC; 1991.

19. Buchalla CM. Aids: o surgimento e a evolução da doença. In: Monteiro CA. Velhos e novos males da saúde no Brasil: a evolução do país e suas doenças. São Paulo: HUCITEC/NUPENS/USP; 1995. p.331-45.

20. Bueno SMV e Valente RB. Revisão bibliográfica sobre aids: categorização por assuntos [resumo]. In: Ciênc Cult 1993; 45 (7 Supl v 1): 127. [Apresentado à 45 Reunião Anual SBPC; 1993 jul 11-16; Recife].

21. Cohn A. Considerações acerca da dimensão social da epidemia de HIV/AIDS no Brasil. In: Simpósio satélite: A epidemia da aids no Brasil: situações e tendências. Brasília: CN DST/AIDS/Ministério da Saúde; 1997. 
22. Collini S. Introdução: interpretação terminável e interminável. In: Eco U. Interpretação e superinterpretação. São Paulo: Martins Fontes, 1997. p. 125.

23. Coordination of the State Program of DST/AIDS. 15 years - State Program STD/AIDS-SP - Center of Reference and Training. São Paulo: State of São Paulo; s.d. ( $n^{o}$ esp.).

24. Denzin NK e Lincoln YS. Handbook of qualitative research. Thousand Oaks, London, New Delhi: Sage Publication International Educational and Professional Publisher; 1997. Entering the field of qualitative research; p.1-17.

25. Figueiredo LCM. Palavras cruzadas entre Freud e Ferenczi. São Paulo: Escuta, 1999. Considerações metodológicas preliminares; p.9-25.

26. Figueiredo RMD de. Prevenção às DST/AIDS em ações de saúde e educação. São Paulo: NEPAIDS; 1998.

27. Foucault M. O nascimento da clínica. Trad. Roberto Machado. São Paulo: Forense Universitária; 1994. Abram alguns cadáveres; p. 141-68.

28. Foucault M. Nietzsche, Freud e Marx: Theatrum Philosoficum. Trad. Jorge Lima Barreto. São Paulo: Princípio; 1997.

29. Foulkes MA. Advances in HIV/AIDS statistical methodology over the past decade. Stat Med 1998; 17(1): 1-25.

30. Freud S. O interesse científico da psicanálise (1913). In: Obras psicológicas completas. Rio de Janeiro: Imago, Ed. Standard Brasileira, 1974, v. XIII.

31. Freud S. Dois verbetes de enciclopédia (1923 [1922]). In: Obras psicológicas completas. Rio de Janeiro: Imago, Ed. Standard Brasileira, 1974, v. XVIII.

32. Garcia-Roza LA. Freud e o inconsciente. $13^{\mathrm{a}}$ ed. Rio de Janeiro: Jorge Zahar Editor, 1996. Pulsão e representação; p. 112-38.

33. Giffin K. Beyond empowerment: heterosexualities and the prevention of AIDS. Soc Sci Med 1998; 46(2): 151-6. 
34. Gomes R. A análise de dados em pesquisa qualitativa. In: Minayo MC de S, Delandes SF, Cruz Neto O, Gomes R. Pesquisa Social: teoria, método e

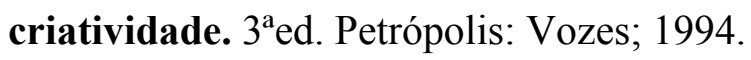

35. Grunsett A, Kippax S. Effects of education on young peolple's sexual behaviour. Austrália; 1993. [Documento produzido pela OMS]

36. Guerriero ICZ. Vulnerabilidade e gênero. Um estudo com homens na cidade de São Paulo. São Paulo; 2001. [Dissertação de Mestrado - Programa de Pósgraduação em Psicologia Clínica da PUC-SP].

37. Harris RM, Kavanagh KH. Perception of AIDS risk and high-risk behaviors in African-American methadone-dependent women. Aids Educ Prev 1995; 7(5): 415-28.

38. Hildebrand PH. A catástrofe aids. IDE - Revista da Sociedade de Psicanálise de São Paulo. 1993; (23): 64-75.

39. Instituto Brasileiro de Ciência e Tecnologia. Universidades e institutos conveniados. Disponível em <URL: http://www.ct.ibict.br:81/site/admin> [1999 jun 13]

40. Lacaz C da S, Gomes SP.5 anos de bibliografia sobre aids/Sida: 1981-1985. São Paulo: CODAC/USP; 1986.

41. Laplanche J, Pontalis J-B. Vocabulário de Psicanálise. Trad. De Pedro Tamen. $5^{\text {a }}$ ed. Lisboa: Moraes; 1970.

42. Lovato LC, Hill K, Hertert S, Hunninghake DB, Probstfield JL. Recruitment for controlled clinical trials: literature summary and annotated bibliography. Control Clin Trials 1997; 18(4): 328-52.

43. Mann JM, Tarantola DJM, Netter TW. Assessing Vulnerability to HIV Infection and AIDS. In: AIDS in the World, The Global AIDS Policy Coalition. Boston: Harvard University Press, 1992: 577-602.

44. Mann JM, Tarantola DJM. Vulnerability: Personal and Programmatic. In: AIDS in the World II - Global Dimensions, Social Roots, and Responses. Boston: Harvard University Press, 1996: 441-3. 
45. Marty P.(1990) A psicossomática do adulto. Trad. De Patrícia Chittoni Ramos. Porto Alegre: Artes Médicas; 1993.

46. Masukawa II, Barone AA. [Bacterial infections in patients with acquired immunodeficiency syndrome (AIDS). Review of literature]. TO: Infeccão bacteriana em pacientes com síndrome da imunodeficiência adquirida (aids). Revisão da literatura. Rev Hosp Clín Fac Med São Paulo 1996; 51(1): 26-33.

47. Mezan R. Problemas de uma história da psicanálise. In: Birman J (org.). Percursos na história da psicanálise. Rio de Janeiro: Ed. Timbre/Taurus; 1988. p.15-41.

48. Minayo MC de S. O desafio do conhecimento: pesquisa qualitativa em saúde. São Paulo-Rio de Janeiro: HUCITEC-ABRASCO; 1994, $3^{\text {a }}$ ed. Fase de análise ou tratamento do material; p.197-247.

49. Ministério da Saúde. Legislação sobre DST \& Aids no Brasil. Brasília: CDIC/PN DST/AIDS, 1995.

50. Ministério da Saúde. Catálogo de organizações não-governamentais. Brasília: Setor de Articulação com ONG/CN-DST/AIDS, 1997.

51. Ministério da Saúde. Aids no Brasil: um esforço conjunto governosociedade. Brasília: CN DST/AIDS, 1998.

52. Olievenstein C. O não-dito das emoções. Trad. Ângela Melim. Rio de Janeiro: Jorge Zahar Ed.; 1989. O não-dito da medicina; p. 127-38.

53. Paiva V (org.). Em tempos de AIDS: viva a vida: sexo seguro, prevenção, drogas, adolescentes, mulheres, apoio psicológico aos portadores. São Paulo: Summus; 1992.

54. Reis AOA. O discurso da saúde pública sobre a adolescente grávida: avatares. São Paulo; 1993. [Tese de doutorado - Faculdade de Saúde Pública da USP].

55. Ricoeur P. Teoria da Interpretação. Lisboa: Edições 70; 1976.

56. Ricoeur P. O conflito das interpretações: Ensaios de hermenêutica. Rio de Janeiro: Imago, 1978. Hermenêutica e psicanálise; p.87-175. 
57. Rorty R. A trajetória do pragmatista. In: Eco U. Interpretação e superinterpretação. São Paulo: Martins Fontes, 1997. p. 105-27.

58. Roudinesco E. Por que a psicanálise? Rio de Janeiro: Jorge Zahar Ed.; 2000. O homem trágico; p.128-42.

59. Roudinesco E, Plon M. Dicionário de psicanálise. Trad. Vera Ribeiro Lucy Magalhães. Rio de Janeiro: Jorge Zahar Ed.; 1998.

60. Sant'Anna PA. Estudo dos arquétipos nos sonhos de portadores de HIV. São Paulo; 1996. [Dissertação de Mestrado - Área de Concentração: Psicologia Clínica Instituto de Psicologia da USP].

61. Soares MB. O estado da alfabetização no Brasil. Brasília: INEP/REDUC; 1989.

62. Sociedade Brasileira de Clínica Médica. Clínica Médica: presente, passado e futuro. São Paulo: Lemos Ed. e Graf.; 1999.

63. Vieira WC. A psicossomática de Pierre Marty. In: Ferraz FC, Volich RM (org.). Psicossoma: psicossomática psicanalítica. São Paulo: Casa do Psicólogo; 1997. p. 15-22.

64. Volich RM. Psicossomática. São Paulo: Casa do Psicólogo; 2000. (Coleção Clínica Psicanalítica) 
ANEXOS 


\begin{abstract}
Anexo 1
Relação de periódicos envolvidos na pesquisa "5 anos de bibliografia sobre AIDS/SIDA", obedecendo a ordem de apresentação dos autores:

New England Journal of Medicine

Annals of Internal Medicine

Nature

Lancet

Science
\end{abstract}

Indicações retiradas de:

Index Medicus

Index Medicus Latino-Americano

Tropical Diseases Bulletin

Current Contends

International Nursing Index 


\begin{abstract}
Anexo 2
Textos relacionados a aspectos psicológicos e psicopatológicos referidos em "5 anos de bibliografia sobre AIDS/SIDA", mantida a numeração e formato de citação:

801 - CALLEN, M. L. - "If I have AIDS, then let me die now!" Hasting Cent. Rep., $\underline{14}: 26,1984$

911 - DURHAM, J. D. \& HATCHER, B. - Reducing psychological complication for the critically ill AIDS patient. Dimens. Crit. Care Nurs., 3:301-6, 1984

943 - FERRARA, A. J. - My personal experience with AIDS. Amer. Psychol., 39:12857, 1984

1004 - GOULDEN, T. et al - AIDS and community supportive service. Understanding and management of psychological needs. Med, J. Aust., 141:582-6, 1984

1174 - LEVINSON, A. J. - "If I have AIDS, then let me die now!" Hasting Cent. Rep., $\underline{14}: 25,1984$

1255 - MORIN, S. F. \& BATCHELOR, W. F. - Responding to the psychological crisis of AIDS. Publ. Heth. Rep. (wash), 99:4-9, 1984

1256 - MORIN, S. F. et al - The psychological impact of AIDS on gay men. Amer. Psychol., 29:1288-93, 1984

1472 - SIMKINS, L. \& EBERHAGE, M. G. - Attituds toward AIDS, herpes II and toxic shock syndrome. Psychol. Rep., 55:779-86, 1984

1557 - VINOGRADOV, S. \& THORTON, J. E. - "If I have AIDS, then let me die now!" Hasting Cent. Rep., 14:24-5, 1984

1765 - DIAS LOPES, J. A. - Na ante-sala da morte. Experiência e conclusões de uma psicóloga paulista que já acompanhou 38 pacientes terminais vitimados pela AIDS.

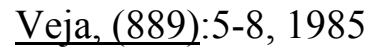

1287 - NURNBERG, H. G. et al - Psychopathology complicating acquired imune deficiency syndrome (AIDS). Amer. J. Psychiat, 141:95-6, 1984
\end{abstract}




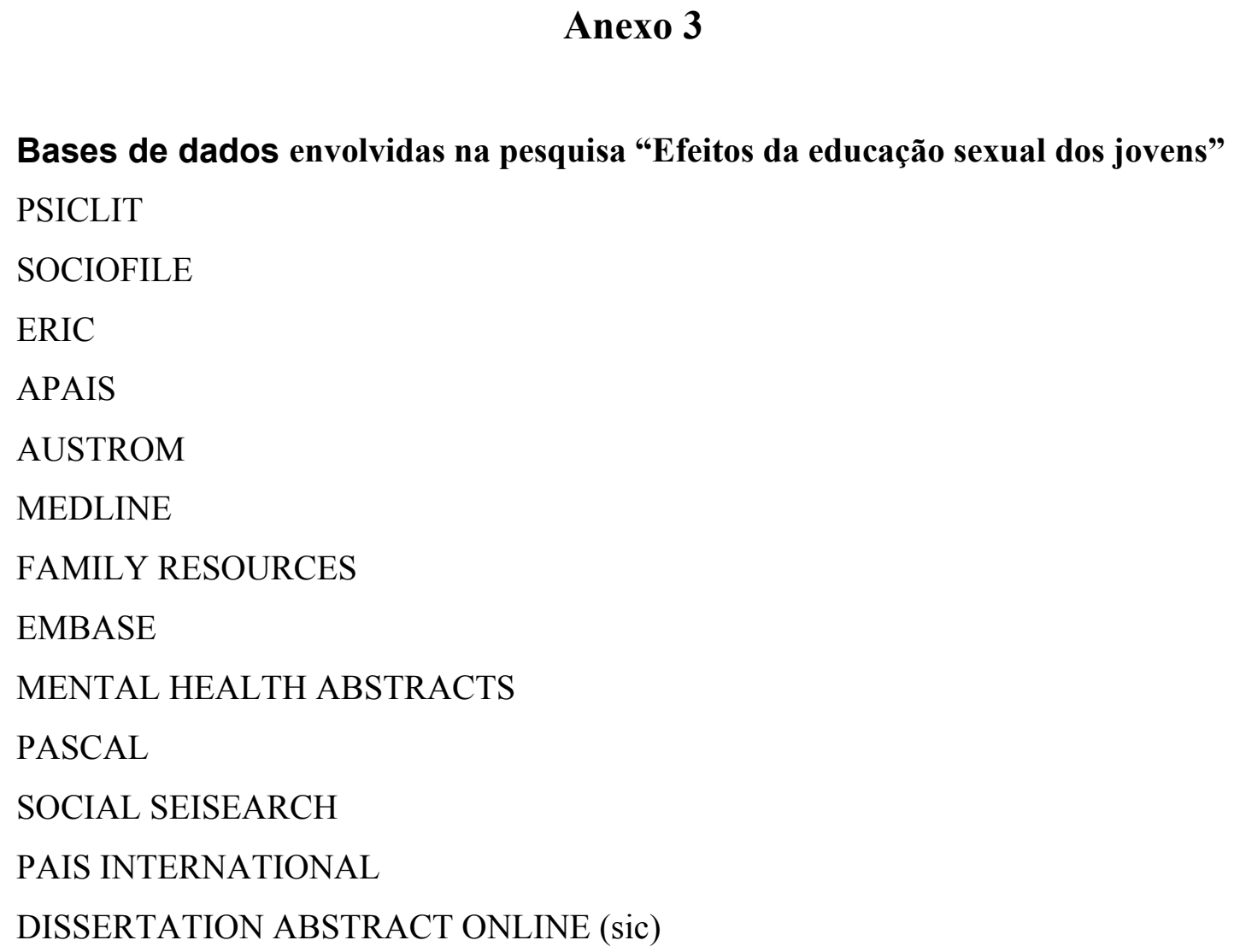




\begin{abstract}
Anexo 4
Relação de textos a que não se teve acesso

1. Campos RCP. Aids e relações de gênero: a trajetória afetivo-sexual de mulheres soropositivas (na cidade de Belo Horizonte/ MG-Brasil). [Dissertação de Mestrado Faculdade de Psicologia - UFMG]

2. Fiuza H. AIDS a doença do medo. Radis, p. 51, out. 1987.

3. Marinho NC (coord.). AIDS-Painel. Rev. do Dep. de Pesquisa Médica da Soc. Bras. De Psicanálise do Rio de Janeiro. 1988; 1: 72-126.

4. Oliveira Neto MX. O paciente homossexual HIV positivo (AIDS) e a morte. J. Bras. de Psiq. 1990; 39(5): 244.

5. Seffner F. O jeito de levar a vida, trajetórias de soropositivos enfrentando a morte anunciada. UFRGS, Porto Alegre, 1995 (mimeo)

6. Souza ARN. A reflexão do saber sobre a impotência - SIDA/AIDS, uma experiência em psicologia médica. Dissertação de Mestrado - Instituto de Psiquiatria, UFRJ, 1988.
\end{abstract}




\title{
Anexo 5
}

\author{
Departamento de Saúde Materno-Infantil \\ FaculdadedeSaúdePúblicadaUSP \\ Av.Dr.Amaldo, 715-Cerqueira César. \\ CEP:01246-904
}

São Paulo, _de de

Prezado(a) Senhor(a),

Estou realizando uma pesquisa de mestrado cujo objetivo é estabelecer o estado do conhecimento no Brasil a respeito dos temas Psicanálise e Aids, desde o início da epidemia. Para tanto, necessito de produções da literatura científica, tais como: artigos, dissertações e teses, livros, capítulos de livros, etc, podendo o material ser ou não indexado.

Caso o(a) senhor(a) possua a referida informação, ou disponha de trabalhos desenvolvidos em sua instituição, gostaria de poder contar com a sua colaboração, no sentido de disponibilizar os dados para consulta. Deixo à sua disposição o e-mail (do pesquisador), os telefones (do pesquisador) e (do Depto. Materno Infantil)e o fax: (do Depto. Materno Infantil).

Peço, ainda, sua atenção e colaboração visando apresentar-nos outros interessados neste tipo de contato (nomes e endereços).

Atenciosamente,

Diva Maria Faleiros Camargo Moreno

Psicóloga - CRP: 06/2233 


\section{Anexo 6}

\section{Relação de textos indicados na bibliografia dos trabalhos analisados}

1. Birman J. A sexualidade entre o mal e as maledicências. In: Loyola MA. (org.) AIDS e sexualidades. Rio de Janeiro: Relume-Dumará/UERJ, 1994. p.109-15.

2. Costa LM, Mello Filho J. Assistência psicológica ao paciente com AIDS. Inform. Psiq. 1987; 6(2): 41-6.

3. Costa LM, Mello Filho J. Atendimento psiquiátrico em um caso de AIDS. Inform. Psiq. 1988; 7(1): 20-5.

4. Fiuza H. AIDS a doença do medo. Radis, p. 51, out. 1987.

5. Klouri C. Paciente terminal: análise possível-impossível, terminável-interminável? Boletim de Novidades Pulsional 1995; 80: 53-4.*

6. Marinho NC (coord.). AIDS-Painel. Rev. do Dep. de Pesquisa Médica da Soc. Bras. De Psicanálise do Rio de Janeiro. 1988; 1: 72-126.

7. Oliveira Neto MX. O paciente homossexual HIV positivo (AIDS) e a morte. J. Bras. de Psiq. 1990; 39(5): 244.

8. Pessoa Labaki ME. A situação do desamparo e AIDS. Pulsional - Revista de Psicanálise. 1999; 119: 17-27.*

9. Sanches RM. Escolhi a vida. Desafios da AIDS Mental. São Paulo, Ed. Olho D’água, 1997.*

10. Seffner F. O jeito de levar a vida, trajetórias de soropositivos enfrentando a morte anunciada. UFRGS, Porto Alegre, 1995 (mimeo)

11. Souza ARN. A reflexão do saber sobre a impotência - SIDA/AIDS, uma experiência em psicologia médica. Dissertação de Mestrado - Instituto de Psiquiatria, UFRJ, 1988.

\footnotetext{
* Textos Recorrentes, obtidos também através do instrumental metodológico da pesquisa.
} 


\section{Anexo 7}

\section{Ficha Técnica*}

Autor:

Instituição:

Local:

Ano:

Título:

Tipo de Produção: artigo, capítulo, tese/dissertação, comunicação em eventos, etc.

Fonte:

Instituição envolvida: consultório privado, serviço de saúde público, escola, serviços comunitários, ONGs, centros de pesquisa, etc.

Tema Principal: aspectos principais focalizados no texto, conteúdo do discurso.

Objeto do Texto: do que trata o texto e conceitos abordados.

Objetivo do Texto: o que o texto pretende explicitar.

Linha Teórica: Freudiana, Kleiniana, Lacaniana, Winnicottiana, Bioniana, outras.

Conclusões: apontadas pelo autor.

Sugestões: a partir das conclusões e das aspirações do autor

Indicação Bibliográfica: textos a que se pode recorrer a partir do estudado, de interesse para o presente estudo.

\footnotetext{
* Baseada na ficha utilizada por REIS (1993) em sua pesquisa bibliográfica
} 


\section{Anexo 8}

\section{Relação de textos excluídos}

1. Abduch M. AIDS: a morte anunciada. Um levantamento de dados. Revista de Psicologia Hospitalar do Hospital das Clínicas de São Paulo. 1993; 3(1): 20-5.

2. Chemana R A AIDS no século. 1998; Correio da APPOA - Associação Psicanalítica de Porto Alegre. 1998; (63): 14-20.

3. Hildebrand PH. A catástrofe AIDS. IDE - Revista da sociedade de Psicanálise de São Paulo. 1993; (23): 64-75.

4. Leguil F, Silvestri D. Psicanalistas confrontados à AIDS. Boletim de Novidades Pulsional. 1995; 80: 22-9.

5. Moura L, Jacquemin A. Aspectos psicossociais da Síndrome da Imunodeficiência Adquirida. Revista de Saúde Pública. 1991; 25(2): 159-62.

6. Ongaro S. A doenças e o doente: relato de vivências hospitalares: um estudo das relações entre medicina e psicologia. 1993. [Tese de doutorado - Instituto de Psicologia da USP]

7. Renômes AV. Quinta fala. In: Jornada Psicanálise e Aids; 1997 jun 28; Campinas, São Paulo. Campinas: Escola Lacaniana de Psicanálise de Campinas; 1998, p.23-6.

8. Vasconcellos EG.A psicoimunologia da AIDS. In: Em tempos de AIDS: viva a vida: sexo seguro, prevenção, drogas, adolescentes, mulheres, apoio psicológico aos portadores. São Paulo: Summus, 1992, p.91-101. 
Anexo 9

Relação das fichas técnicas dos textos analisados 


\section{FICHA TÉCNICA - TEXTO 1}

Autor: Lizete Pontes Macario Costa e Julio de Mello Filho

Instituição: Hospital Universitário Pedro Ernesto da Universidade Estadual do Rio de Janeiro

Local: Rio de Janeiro

Ano: 1987

Título: Assistência psicológica ao paciente com aids

Tipo de Produção: Artigo

Fonte: Revista Informação Psiquiátrica. 1987, 6(2): 41-46.

Instituição Envolvida: Enfermaria de Doenças Infecto Parasitárias do Hospital referido acima.

Tema Principal: Psicoterapia de pacientes com aids internados no Hospital

Sub-temas:

a) Homossexualismo

b) Morte

Objeto do Texto: Trata-se do relato da experiência de assistência e apoio psicológico a pacientes portadores de aids internados no Serviço de Doenças Infecto-contagiosas do HUPE (Rio de Janeiro).

Conceitos abordados: narcisismo, escolha de objeto, castração, identidade.

Objetivo do Texto: Refletir sobre a exigência de um trabalho conjunto com a equipe médica auxiliar, a dificuldade de se lidar com o preparo do paciente para a morte e com a realidade de uma doença nova, sem perspectivas de cura.

Linha Teórica: Freudiana e de autores da chamada Psicoimunologia (Salomon e Ader)

Conclusões: (colocadas em relação a cada tema tratado)

a) Sobre a psicoimunologia e a aids: “... sabe-se que a psique atua sobre o sistema imune através dos neurotransmissores, do sistema nervoso vegetativo e dos hormônios." (p.42) Os autores seguem essa linha de raciocínio para explicar como as células de defesa contra infecções e neoplasias (os linfócitos T) podem sofrer com as condições de stress e más condições psicológicas. Por analogia, sem ainda haver estudos a esse respeito, consideram que os doentes de aids, sendo em sua maioria constituídos por homossexuais, hemofílicos e toxicômanos (na ocasião da elaboração deste trabalho), com desadaptação em função de suas situações especiais de vida, estariam mais sujeitos às dificuldades de atuação do seu sistema imunológico, sofrendo a ação direta do vírus HIV. Isso poderia explicar a rapidez com que passam da condição de soropositivos à condição de doentes de aids (com sintomatologia), em decorrência de múltiplos fatores como depressão, mánutrição, fadiga, stress, crises existenciais, etc, debilitando as defesas e quebrando o equilíbrio homeostático, fazendo surgir a doença.

b) Os autores verificaram ainda, a dificuldade de se lidar com o impacto do diagnóstico, a reação aos sintomas físicos e com a ansiedade e o medo. Constataram a importância de se abrir um espaço para a manifestação dos sentimentos e temores como forma de alívio da angústia. A colaboração 
dos familiares e amigos também se mostrou uma coadjuvante na lida com a dor e o sofrimento decorrentes da condição de doente de aids.

c) Sendo a maioria dos pacientes homossexuais, os autores dedicaram uma seção a esse tema, adotando a concepção freudiana da determinação da escolha de objeto homossexual: a forte ligação com a mãe, o narcisismo e o temor da castração.

Diante das características, o trabalho de atendimento dos pacientes pelos profissionais, no caso os autores, é considerado difícil tanto no que diz respeito à coleta de dados, quanto à intervenção propriamente dita, que freqüentemente envolve terceiros. O paciente recusa-se, algumas vezes, a comunicar a doença e a homossexualidade à família. A família, por sua vez, também resiste a aceitar a "nova" realidade (destaque nosso).

d) A abordagem da morte: "O processo de morrer causa um sofrimento muito evidente..." (p.46). Isso começa pela internação, que já separa o paciente de seu parceiro, família e amigos. Se o paciente é colocado no isolamento, a angústia se intensifica ainda mais. É como se fosse "uma morte em vida". Se o espaço é aberto para o diálogo, para falar da morte, da vida, dos temores, pode haver um rebaixamento da angústia e a obtenção de uma certa tranqüilidade pelo paciente e não o vazio causado pela evitação do assunto por todos.

Sugestões: A conclusão "d" pode ser entendida como uma sugestão de abordagem desse tipo de paciente.

Obs.: O leitor pode saber mais a esse respeito no texto 2 do presente estudo, cujos autores são os mesmos.

Indicação Bibliográfica: Não foi encontrada referência de interesse para o presente estudo.

\section{FICHA TÉCNICA - TEXTO 2}

Autor: Lizete Pontes Macario Costa e Julio de Mello Filho

Instituição: Hospital Universitário Pedro Ernesto da Universidade Estadual do Rio de Janeiro

Local: Rio de Janeiro

Ano: 1988

Título: Atendimento psicoterápico em um caso de aids

Tipo de Produção: Artigo - Seção Clínica

Fonte: Revista Informação Psiquiátrica. 1988, 7(1): 20-5

Instituição Envolvida: Setor de Psicologia Médica e Serviço de Doenças Infecto Parasitárias da Instituição acima citada

Tema Principal: Acompanhamento psicoterápico de um paciente com aids

Sub-temas:

Homossexualidade

Identidade Sexual

Setting/holding 
Objeto do Texto: Trata-se do relato da experiência de acompanhamento psicoterápico de um paciente com aids.

Conceitos abordados: holding, setting, defesa, resistência, perversão, masoquismo, negação e complexo de Édipo.

Objetivo do Texto: Relatar a experiência e trazer dados da história, do desenrolar da doença e do modo como os autores lidaram com momentos difíceis da relação com o doente, sua incurabilidade e a perspectiva da morte. Descrever a atuação do serviço de atendimento a pacientes com doenças infecto-contagiosas da instituição envolvida.

Linha Teórica: Utilizam-se de conceitos da teoria Winnicottiana, Freudiana e de autores contemporâneos (MACDOUGALL, STOROLLON e KOHUT)

Conclusões: Após uma descrição da história do paciente e do desenvolvimento do vínculo terapêutico no hospital (durante a internação), no ambulatório e no domicílio, a autora chega a algumas conclusões a respeito da dinâmica psíquica do paciente e da natureza desse tipo de atendimento:

"O doente grave (...) não contém em si apenas o germe da morte e da inevitabilidade que os médicos, por sofrimento, tanto temem. Contém todo um potencial de vida de lições e de momentos por vezes muito mais profundos do que quando possuíam saúde de modo completo. O desafio da morte pode ser enfrentado de perto, com diálogo, presença e interação, e se constituir uma das mais concretas experiências de vida que o ser humano possa participar" (p.22).

A relação médico-paciente (e toda a equipe), sendo positiva, propicia um suporte para a manutenção dos tratamentos, às vezes difíceis. Inclui-se, aí, a possibilidade de atendimento na enfermaria, no ambulatório e na casa do paciente, ampliando-se muito o conceito de setting terapêutico.

A empatia (compreensão do paciente através da possibilidade de se colocar na posição do mesmo) deve ser exercida e desenvolvida em pacientes somáticos. Falhas neste aspecto podem ocasionar sofrimento do paciente, que não se sente atendido em suas necessidades psicológicas. "Saber ouvir, permitir uma relação em setting não rígido, estava de acordo com as necessidades do paciente que pedia um compromisso por parte de quem vai acompanhar, pois ele remove céus e terra para chegar numa sessão, por exemplo, desejando que eu correspondesse à intensidade deste vínculo" (p.24).

Os autores consideram a experiência de acompanhamento de um paciente até a sua morte uma das mais completas que um profissional de saúde pode ter. Ela envolve dignidade, aprendizado e vida. A morte, sem apenas destruir e consumir, pode também fertilizar a vida. A experiência, vivida na plenitude pelo profissional e pela equipe, pode ser “... fator de agregação, solidariedade e de crescimento, diante da possibilidade de lidar com as situações limítrofes da existência humana" (p.25).

Sugestões: não há 
Indicação Bibliográfica: Não foi encontrada referência de interesse para o presente estudo.

\section{FICHA TÉCNICA - TEXTO 3}

Autor: Lizete Pontes Macário Costa, Cesar Queiroz Lima e Julio de Mello Filho

Instituição: Serviço de Doenças Infecto Parasitárias e Setor de Psicologia Médica do Serviço de Psiquiatria do Hospital Universitário Pedro Ernesto da Universidade Estadual do Rio de Janeiro Local: Rio de Janeiro

Ano: 1989

Título: Grupoterapia com pacientes HIV Positivos (Aids)

Tipo de Produção: Artigo

Fonte: Informação Psiquiátrica. 1989; 8(3): 97-103.

Instituição Envolvida: A mesma acima citada

Tema Principal:

a) Atendimento grupal em psicoterapia

b) Sentimentos dos profissionais envolvidos

c) Psicoimunologia e aids.

d) Relação médico-paciente

Objeto do Texto:

Relatar a experiência de assistência médico-psicoterápica em grupo com pacientes HIV positivos sem doença manifesta (homo e bissexuais). Trata da questão do homossexualismo.

Conceitos abordados: angústia, identidade, negação maníaca, mecanismo de luta e fuga.

Objetivo do Texto:

Enfatizar as vicissitudes do atendimento em psicoterapia de grupo tais como: diagnóstico dos pacientes, estabelecimento da relação médico-paciente, encorajamento da exposição de dúvidas sobre sintomas, contágio e questões mais profundas, como fantasias de morte, medo do aparecimento da doença e o problema das identidades sexuais. Favorecer através da orientação médica a adaptação às novas condições de vida e possibilitar uma reconstrução de suas imagens pessoais (self) e parentais através da ação dos terapeutas. Objetivo do Grupo: criar condições para os pacientes discutirem suas angústias, expectativas de vida, fantasias de morte e toda a gama de sentimentos despertados a partir do diagnóstico.

Linha Teórica: Cita FREUD e autores da psicossomática (MCDOUGALL)

Conclusões: O trabalho de grupoterapia favorece o surgimento de laços familiares no momento em que os pacientes sentem-se abandonados por amigos e parentes, podendo nessa nova família discutir abertamente seus temores, conflitos e fantasias. Possibilita ajuda no esclarecimento de dúvidas quanto aos sintomas, problemas de identidade sexual, sentimentos de rejeição, rivalidade, perspectivas de futuro (destaque nosso). Os pacientes reagem com atitudes que alternam posições de negação maníaca, luta e fuga, culto à dor, acasalamento e dependência, bem como motivos de 
integração e coesão.

Sugestões: Importância de um trabalho de apoio e orientação em momentos difíceis, que pode auxiliar no enfrentamento do diagnóstico, da necessidade de contá-lo para parceiros e familiares, no trabalho de identidade sexual, culpa pela infecção. Pode possibilitar ainda, dissipar fantasias precipitadas de fim e assumir a homossexualidade.

Indicação bibliográfica:

Costa LM, Mello Filho J. Assistência psicológica ao paciente com aids. Inform. Psiq. 1987; 6(2): $41-6$.

Costa LM, Mello Filho J. Atendimento psiquiátrico em um caso de aids. Inform. Psiq. 1988; 7(1): $20-5$.

\section{FICHA TÉCNICA - TEXTO 4}

Autor: Maria de Lourdes Caleiro Costa

Instituição: Departamento de Psicanálise do Instituto Sedes Sapientiae

Local: São Paulo

Ano: 1991

Título: Aids: vida e morte em nossas vidas

Tipo de Produção: Artigo

Fonte: Revista Percurso. 1991; 7(2): 41-3.

Instituição Envolvida: Não explicitada.

Tema Principal: Conflitos psíquicos e sociais expostos pela aids que a civilização tem escamoteado Sub-temas: Solidão, medo e morte

Objeto do Texto: A imposição da questão da aids, direta ou indiretamente, nos consultórios, nas políticas de saúde pública, nos círculos de convivência social ou familiar e em cada indivíduo.

Conceitos abordados: o sinistro (ou o estranho), repressão, inconsciente.

Objetivo do Texto: Indagar sobre a forma de se viver com a aids (sendo ou não soropositivo); como intervir, enquanto profissionais de saúde nessa doença; como equacionar a liberdade sexual de cada um diante da epidemia e como contribuir para a compreensão e superação dos problemas utilizando o referencial psicanalítico.

Linha Teórica: Freudiana.

Conclusões: A forma de articulação das campanhas de prevenção em nosso país faz do doente de aids uma figura estranha e ameaçadora, “... a própria corporificação da doença” (p.43). Envolve um mecanismo de culpabilização e pecado que pune aqueles acometidos por ela.

CALEIRO COSTA utiliza-se do conceito de sinistro de FREUD (1919) para compreender o tom e a mensagem das referidas campanhas, considerando que a aids estaria representando "... tudo o que deveria ter ficado oculto, secreto, mas que se manifestou" (p.43). Esse "tudo", segundo a autora, seria a forma como o ser humano lida com a mortalidade ou a imortalidade, fazendo emergir 
conteúdos infantis há muito reprimidos, ligados ao medo e à angústia. Assim, dor, isolamento, solidão e a morte, presentificados no doente de aids (nesse momento, em sua maioria, homossexuais, bissexuais e usuários de drogas), são os perigos que precisam ser mantidos afastados, ocultos, para não ferirem um "todo narcísico" (destaques nossos).

Sugestões: Ocorre à autora a necessidade de “... cuidar da morte não como estrangeira, assim como não são estrangeiros aqueles que a portam e (...) cuidar da vida, de suas múltiplas e singulares possibilidades radicalmente" (p.43).

Indicação bibliográfica: Não foi encontrada referência de interesse para o presente estudo.

Obs.: A autora cita o desenvolvimento da epidemia no Brasil e ressalta a mudança da terminologia "grupos de risco" para "comportamento de risco". Parece estar indignada com o que ela denominou 'engodo nacional' das campanhas de prevenção, em que medo e preconceitos articulam-se e fomentam mais preconceito, não prestam o serviço de informar, acarretando um aumento na progressão da epidemia. Reflete sobre a questão da aids ser doença do outro e não de mim. Relembra a opinião de Herbert DANIEL, segundo a qual o cidadão está imerso num estereótipo onde existe uma função anestésica, cuja finalidade é o esvaziamento da consciência do problema social e uma função camufladora que serve para atribuir ao enigma e ao mistério os problemas sociais e humanos concretos. (destaques da autora).

\section{FICHA TÉCNICA - TEXTO 5}

Autor: Roosevelt M. S. Cassorla

Instituição: Faculdade de Ciências Médicas da UNICAMP

Local: Campinas-SP

Ano: 1991

Título: Lidando com aids: uma experiência de supervisão de equipe

Tipo de Produção: Capítulo de Livro

Fonte: Cassorla RMS (coord). Da morte: estudos brasileiros. Campinas: Papirus; 1991. p.231-41.

Instituição envolvida: Entidade que trabalha com doentes e portadores do vírus da aids

Tema Principal: Experiência como supervisor da equipe multiprofissional.

Objeto do Texto: Descrever a experiência. Utiliza conceitos da teoria psicanalítica para compreender os mecanismos envolvidos e as emoções despertadas nos profissionais de saúde que lidam com o paciente de aids e soropositivos.

Conceitos abordados: negação, rêverie (BION) ou continência, transferência e contratransferência, identificação, idealização, narcisismo, atuação, sentimento de culpa e masoquismo.

Objetivo do Texto: Refletir sobre o que a experiência proporcionou. Ilustrar situações comuns no dia a dia do trabalho com os doentes de aids e soropositivos, e o impacto nos profissionais de saúde. Compreender os mecanismos envolvidos no trabalho.

Linha teórica: Grupos BALINT, BION 
Conclusões: As diferenças no trabalho com aids levam o profissional a defrontar-se com aspectos específicos, tais como: medo do contágio, medo de que outros saibam que ele lida com aids, obter uma grande quantidade de informações científicas ou não, dificuldades de lidar com homossexuais, toxicômanos, prostitutas, etc., imprevisibilidade do diagnóstico e prognóstico, o trabalho com pacientes jovens no auge de sua força vital, ter que se haver com a morte e o morrer (tendo o profissional ter que se defrontar com sua própria morte), lidar com a impotência, a desesperança, a agressividade, a negação, a atuação e toda a gama de mecanismos mentais que invade o profissional e problemas sociais decorrentes do diagnóstico HIV positivo.

Diante disso, o ideal é que a equipe aproveite todas as experiências que vive para o seu próprio desenvolvimento, incluindo as formas de ver a vida e a sabedoria no viver.

Há necessidade de um vínculo forte de confiança e acolhimento, que muitas vezes só a equipe de saúde pode dar, através da rêverie (BION) ou continência. As reações primitivas do paciente poderão surgir através da transferência em relação ao profissional de saúde e as suas reações (contratransferência) dependerão de como esse lidou com seus próprios aspectos passados, e como eles internalizaram-se em seu mundo interno. Os mecanismos de identificação, idealização podem se fazer presentes, bem como as características narcísicas, a insegurança, a incapacidade de pensar provocada pelas circunstâncias do atendimento podem levar o profissional à atuação, ao sentimento de culpa, a atitudes de masoquismo, etc.

Sugestões: Quando se trata da aids é necessário trabalhar em equipe, usando todos os recursos da comunidade. Equipe deve ser supervisionada por um profissional médico (de preferência com formação em psicanálise). Ouvir uns aos outros sem preconceitos ou julgamento, no desespero, no desânimo e na confusão. Tentar examinar os sentimentos e reações dos profissionais. Efetuar reuniões de equipe formais. Fazer análise pessoal quando necessário. Um profissional com fobia ao homossexualismo deverá evitar se especializar em aids.

\section{Indicação Bibliográfica:}

Marinho NC (coord.). Aids-Painel. Rev. do Dep.de Pesquisa Médica da Soc. Bras. De Psicanálise do Rio de Janeiro. 1988; 1: 72-126.

\section{FICHA TÉCNICA - TEXTO 6}

Autor: Idésio Milani Tavares

Instituição: Sociedade Psicanalítica do Rio de Janeiro

Local: Rio de Janeiro

Ano: 1991

Título: Perseu - O mito e o complexo: uma variante do complexo de Édipo

Tipo de Produção: Artigo/Trabalho apresentado em congresso

Fonte: Revista Brasileira de Psicanálise

Instituição Envolvida: Trata-se de reflexão teórica. 


\section{Tema Principal:}

Discute a resolução do complexo de Édipo, utilizando-se do mito Perseu e a cabeça da Medusa, com um desfecho diferente da estrutura normal e neurótica, mas o relacionando a uma estrutura perversa.

Objeto do Texto: Refletir sobre o tema acima.

Conceitos abordados: complexo de Ëdipo, mecanismo da recusa, pulsão de morte, estrutura perversa, identificações primária e secundária.

Objetivo do Texto: Investigar o mito e destacar, no episódio da Medusa, as relações entre Perseu e as figuras masculinas e femininas que povoam a narrativa.

\section{Linha Teórica: Freudiana e Lacaniana}

Conclusões: Trata-se de uma reflexão metapsicológica, cujo interesse primordial é discutir a dinâmica psíquica do indivíduo constituído por uma estrutura perversa. Utiliza o mecanismo da recusa que impede a apropriação ou internalização da lei paterna. $\mathrm{O}$ indivíduo fica sujeito à ação da pulsão de morte, pois o seu ego dividido e frágil o deixa propenso a procedimentos destrutivos como a "...drogadição, contaminação por aids, relacionamentos sadomasoquistas, e, às vezes, homicídio e suicídio" (p.303).

Expõe-se algumas citações do texto de TAVARES que são necessárias para a compreensão das reflexões de TAVARES:

“(...) o perverso não tem um superego completo pelo fato de seu Complexo de Édipo não ter sido constituído totalmente $\mathrm{e}$, portanto, não ter sido declinado. Conseqüentemente, o que não chegou a se constituir completamente não pode ter sido herdado por inteiro" (p.311).

O autor postula, utilizando vários autores que "o ego não edipiano: 'a relação binária que não pode utilizar o terceiro termo da triangulação', 'a recusa e a impossibilidade de organizar a imago paterna diferentemente da relação sádica com a mãe', 'o não poder investir e assimilar a imago paterna', devem-se à recusa (Verleugnung) que, dividindo o ego, impede a assimilação de qualquer modelo paterno numa de suas partes cindidas e provoca a formação de um superego incompleto. Portanto, a uma clivagem egóica segue-se uma clivagem superegóica” (...).

“...devido à inconsistência e incompletude desse superego, as identificações primárias - que são feitas diretamente no id - não são reforçadas pelas secundárias deixando a mercê, também, de um outro superego totalmente imerso no id, portanto sob a influência do processo primário" (...).

"Esse superego tirânico impregnado pela pulsão de morte impele o perverso a procurar o gozo absoluto, a transgredir todos os limites, acabando por levá-lo a situações auto e heterodestrutivas tais como: relacionamentos sadomasoquistas, drogadição, contaminação por aids, homicídio e suicídio" (...).

Portanto, quanto mais fracas e incompletas as identificações resultantes do complexo de Édipo que, por conseqüência, geram um supergo frágil, mais intensamente o perverso estará submetido ao superego tirânico" (p.312). 
O autor postula, ainda, “...que o modelo analítico é o adotado pelo perverso nos moldes daquele sugerido por FREUD em Sobre o narcisismo: uma introdução (1914)" (p.312-3).

Os movimentos transferenciais determinados por este tipo de funcionamento psíquico são característicos: “...há ocasiões em que a análise transcorre sem maiores flutuações afetivas e a sensação é de que o analisando fala para e com alguém que não o analista; este 'não existe' e o analisando comporta-se como se tivesse numa relação exclusiva com a mãe [ou] quando o analista interpreta (o que é sentido como uma tentativa de entrada do pai e de castração), portanto, quando 'existe', surgem protestos furiosos, discordâncias veementes e os 'acting-out'.”(p.313).

Sugestões: Para a questão da aids não há sugestões. Para a psicanálise o autor sugere que da estrutura perversa faz parte uma variante do complexo de Édipo que pode ser denominada de Complexo de Perseu.

Indicação Bibliográfica: Não foi encontrada referência de interesse para o presente estudo.

\section{FICHA TÉCNICA - TEXTO 7}

Autor: Jurandir Freire Costa

Instituição: Instituto de Medicina Social de Saúde Coletiva da UERJ

Local: Rio de Janeiro

Ano: 1992

Título: O homoerotismo diante da aids

Tipo de Produção: Capítulo de livro

Fonte: A inocência e o vício: estudos sobre o homoerotismo. Rio de Janeiro: Relume-Dumará; 1992. O homoerotismo diante da aids. p.127-95.

Instituição envolvida: Consultório privado de psicanálise e centros de pesquisa.

\section{Tema Principal:}

Reações dos sujeitos homoeroticamente orientados frente ao risco de infecção para o HIV.

Objeto do Texto: O texto trata do homoerotismo e da construção da identidade do indivíduo "homossexual". O termo homossexual aparece sempre destacado no texto, pois o autor o considera preconceituoso e decorrente de uma cultura oitocentista que considera a homossexualidade uma patologia.

Conceitos abordados: identidade, inconsciente estruturado como uma linguagem.

Objetivo do Texto: Refletir sobre a hipótese de que “... o risco de infecção entre indivíduos homoeroticamente inclinados está diretamente relacionado à maneira como lidam com o preconceito dirigido contra suas preferências sexuais" (p.127).

Linha Teórica: Lacaniana

Conclusões:

O autor analisa as respostas dos 'homossexuais' diante da aids ou do risco de infecção propõe uma classificação das reações dos sujeitos homoeroticamente orientados frente ao risco de infecção para 
o HIV. Faz a ressalva da não pretensão de exaustividade desta proposta, por estar baseada na amostra estudada.

a) Proteção pelo preconceito.

Indivíduos majoritariamente identificados com as regras da moral sexual oitocentista, basicamente, o grupo de clientes. $\mathrm{O}$ autor descreve uma série de traços comuns observados nestes sujeitos.

\section{b) Proteção contra o preconceito}

Indivíduos que se aproximam do modelo gay de identidade homoerótica. Características:

- aceitação plena da "identidade homossexual".

- A revalorização dessa identidade contra o preconceito e o estigma desvalorizante que o envolve.

c) A privatização moral na avaliação do risco da infecção.

Indivíduos com impossibilidade de dispor de modelos de identidade sexual publicamente discutíveis e partilháveis por outros. Por isso eram os mais expostos aos riscos de infecção. Resolviam "individualmente" a questão da prevenção.-Eram a maioria dos pesquisados.

$\mathrm{O}$ autor considera que possam existir outras formas de estabilização ${ }^{1}$ da identidade homoerótica que ultrapassam os limites do universo estudado. Dentre os pesquisados, observou-se que existe uma diferença na eficiência frente ao desafio da aids, conforme a identidade do sujeito seja constituída. Em outras palavras, a eficência das atitudes de proteção da infecção pelo HIV depende da forma como o sujeito se posiciona frente à sua "homossexualidade" (destaque do autor).

Sugestões: COSTA, a partir de suas conclusões, considera importante continuar a dirigir ao grupo dos chamados homossexuais as informações sobre a prevenção, de forma melhorada e articulada com o combate ao preconceito. Na sua opinião, “(...) quanto mais os indivíduos têm condição de discutir publicamente o problema do homoerotismo, mais têm condição de optar por regras claras de definição da 'identidade homoerótica' e mais encontram suporte nessas regras para aceitar as limitações da vida sexual impostas pela aids" (p.191-2). Sem isso, as decisões dependem de cada um e, conseqüentemente, nem sempre podem beneficiar a coletividade.

Indicação Bibliográfica: Não foi encontrada referência de interesse para o presente estudo.

\section{FICHA TÉCNICA - TEXTO 8}

Autor: Virgínia Fontenelle Eksterman, Ana Cristina M. Prococi, Lisandre F. Oliveira Fairclough, Márcia Pinto Fontenelle Mello e Patrícia Corina Rocha.

Instituição: de atendimento a pacientes hemofílicos

Local: Rio de Janeiro

Ano: 1992

\footnotetext{
${ }^{1}$ Segundo conceituação de PLUMMER: “...aceitação dos plenos sentimentos e modos de vida”. (p.144)
} 
Título: Hemofilia e aids

Tipo de Produção: Capítulo de Livro

Fonte: Mello Filho J de e col. Psicossomática Hoje. Porto Alegre: Artes Médicas; 1992. p.325-33. Instituição Envolvida: Ambulatório, enfermaria e albergue para pacientes hemofilia (não identificados no texto)

Tema Principal:

a) Modificações na instituição depois do advento da aids

b) Atendimento psicológico aos pacientes e familiares

c) Angústia frente hemofilia e sua reedição a partir da aids

Sub-temas:

Aspectos clínicos da hemofilia

Objeto do Texto: Refletir sobre a experiência de 3 anos no atendimento aos pacientes hemofílicos de uma instituição para esta patologia.

Conceitos abordados: luto e identidade.

Objetivo do Texto: Relatar o resultado da experiência de dar atendimento psicoterapêutico baseado na teoria psicanalítica (fora do setting).

Linha Teórica: Não identificada no texto.

Conclusões:

a) O processo de adoecer de aids revivia todo o processo da hemofilia e reeditava aquela dor, pois o paciente já convivia com uma deficiência crônica. O corpo do paciente hemofílico é limitado desde cedo pelas complicações da doença e pelas constantes intervenções pela carência do fator coagulante no sangue. Em decorrência disso, freqüentemente ele vivencia a fantasia de um corpo vazio preenchido pelo sangue dos outros.

b) Seu "eu" é hemofílico, não se sente uma pessoa. A tomada de consciência de fazer parte de um "grupo de risco" para a aids faz com que já viva um "estar infectado" pelo vírus. A nova doença vem selar as deficiências e dificuldades existentes na vida do paciente, inclusive a concretude de ameaça de morte.

c) A angústia destas pessoas é transferida para o psicólogo, que passa a viver também sentimentos de dor, perda e limitações. O papel de holding do psicólogo pode possibilitar a integração dentro de uma realidade "impossível” (destaque nosso)

Sugestões: Não há

Indicação Bibliográfica: Não foi encontrada referência de interesse para o presente estudo.

\section{FICHA TÉCNICA - TEXTO 9}

Autor: Cláudio Vital de Lima Ferreira

Instituição: Universidade Estadual de Campinas - Faculdade de Ciências Médicas - Campinas-SP

Local: Campinas-SP 
Ano: 1992

Título: Conversando com o paciente HIV positivo: um estudo clínico

Tipo de Produção: Tese de Doutorado

Fonte: -

Instituição Envolvida: Enfermaria de Moléstias Infecto-contagiosas do Hospital das Clínicas da Universidade Federal de Uberlândia-MG

Tema Principal: Dinâmica psíquica dos pacientes portadores do HIV*, aspectos bio-psico-sociais da aids, o doente de aids como especial, com um mundo pessoal trazido para o centro do foco;

Sub-temas:

Poder do médico cai no vazio frente à impossibilidade de cura e volta-se para o próprio paciente da situação.

Objeto do Texto: Estudo dos mecanismos psicológicos dos pacientes utilizando-se o método clínico e o referencial teórico psicanalítico.

Conceitos abordados: Mecanismos defensivos: negação, defesas fóbicas e obsessivas, castração, transferência positiva.

Objetivo do Texto: (e da pesquisa)

Conhecer e estudar o que os pacientes têm a dizer sobre si mesmos e os mecanismos psicológicos envolvidos, a partir de conceitos psicanalíticos. Investigar o efeito da condição de HIV positivo na vida, nas relações interpessoais e nos planos para o futuro do paciente. Estudar o sentido e o significado do diagnóstico, prognóstico e tratamento para os pacientes.

Linha Teórica: Freudiana

Conclusões:

a) Diante da soropositividade e da doença surgem três possibilidades:

$a_{1}$ ) O suicídio, que ocorre pela incapacidade do paciente para cuidar de si mesmo e de sua saúde. Para FERREIRA, “... é a concretização da castração sobre a forma de autodestruição” (p.43);

$\mathrm{a}_{2}$ ) O paciente divide a tarefa com pessoas de sua relação de afeto, melhorando sua qualidade de vida e suas relações com estas pessoas.

$a_{3}$ ) O paciente lança mão do mecanismo de negação para não entrar em contato com a gravidade da doença que o acomete.

FERREIRA assinala que, apesar da mobilidade do vírus HIV, ele não tem tido a força para alterar o fato de que o processo evolutivo é diferente para cada paciente, o que força os profissionais de saúde a encontrar algumas respostas para a doença não mais no vírus, mas nas características do sujeito.

Alguns pacientes conseguem lidar com os novos problemas de maneira adequada e demonstram possuir níveis mais baixos de angústia associados aos próprios sentimentos infantis ambivalentes.

\footnotetext{
* O autor acompanhou 15 pacientes.
} 
$\mathrm{O}$ autor deduz que as atuais dificuldades dos pacientes, principalmente quanto à sexualidade e uso de drogas, sejam uma conseqüência das dificuldades pessoais emocionais primitivas. Contudo, isso nem sempre é verdadeiro, pois alguns pacientes, frente aos problemas pessoais e sociais, desenvolvem defesas que lhes servem de recurso para lidar com o vírus HIV, quando este é incorporado às suas vidas.

Os pacientes tiveram, de modo geral, melhora na qualidade de vida depois que souberam do diagnóstico e oportunidade de repensar seus valores. “... a dor e o sofrimento trazido pelo vírus, não foram em vão. Mesmo o paciente que tentou o suicídio, um ano depois da tentativa, nos disse numa reunião com outros pacientes que não repetiria o que fez" (p.193).

Sugestões: As questões psicológicas precisam ser relevadas pelos médicos. Para tanto, o profissional médico deve procurar desenvolver condições mínimas para abordar essas questões com o paciente e poder ajudá-lo.

Indicação Bibliográfica: Não foi encontrada referência de interesse para o presente estudo.

\section{FICHA TÉCNICA - TEXTO 10}

\section{Autor: Célia Klouri}

Instituição: Pontifícia Universidade Católica de São Paulo - Programa de Estudos Pós graduados em Psicologia Clínica

Local: São Paulo

Ano: 1992

Título: Drogadição e aids: vivendo entre duas mortes

Fonte: -

Tipo de Produção: Dissertação de Mestrado

Instituição Envolvida: Instituto de Infectologia Emílio Ribas

Tema Principal: Drogadição e aids

Sub-tema: Modo particular com que os usuários de drogas lidam com o diagnóstico de aids

Objeto do Texto: A problemática da aids e do consumo de drogas injetáveis em pacientes do Instituto de Infectologia Emílio Ribas

Conceitos abordados: narcisismo, castração, onipotência, pulsão de morte e negação

Objetivo do Texto: "Estudar, a partir de um referencial psicanalítico, o efeito da aids sobre quatro usuários de cocaína injetáveis infectados pelo HIV (...) identificando: a) os dinamismos psicológicos envolvidos no consumo de drogas; b) a reação ao impacto do diagnóstico de uma doença fatal, transmissível, longa, desfigurante; c) a atitude frente às limitações impostas pelo diagnóstico; d) as alterações provocadas no psiquismo pela doença"(p.74).

Linha Teórica: Freudiana e Lacaniana

Conclusões:

KLOURI constatou que “... os usuários de droga apresentam uma organização narcisista, 
onipotente de personalidade, com componentes masoquistas e com dificuldade em lidar com os limites, com a angústia de castração. Diante da aids, a reação foi de negação e de revolta, mas posteriormente expressaram medo do desfiguramento e da manifestação da doença. A aids trouxe à tona a ferida narcísica e a temática da castração, representada pelos limites e pelas perdas impostos pela doença” (p.1).

“... a drogadição é um tipo especial de dependência humana... [cuja] origem pode ser encontrada nas etapas primitivas do desenvolvimento humano" (p.22).

As dificuldades de lidar com as perdas podem levar ao uso de drogas

Sugestões:

A autora sugere que os programas de prevenção e tratamento do uso de drogas devem levar em conta a dinâmica psíquica descrita por ela.

No Brasil, há contradições e discrepâncias observadas nas pesquisas sobre o uso de drogas e nas notícias veiculadas pela imprensa que necessitam de esclarecimento. Isso poderia ser obtido através de estudos que avaliem a real situação do consumo de cocaína e outras drogas, visando encarar a drogadição como um importante problema na área da saúde, além de sensibilizar os vários segmentos e instituições sociais, envolvendo-os na prevenção tanto desse problema, quanto da aids. Deveria haver um maior número de estudos psicológicos sobre a dependência de drogas, que incluísse a estrutura familiar, os primórdios da infância dos drogaditos e a dinâmica psicológica envolvida no uso de droga em grupo.

Indicação Bibliográfica: Não foi encontrada referência de interesse para o presente estudo.

\section{FICHA TÉCNICA - TEXTO 11}

Autor: Anna Verônica Mautner

Instituição: Consultório particular

Local: São Paulo

Ano: 1992

Título: Vida e Morte

Fonte: Paiva V (Org.). Em tempos de aids. Viva a vida: sexo seguro, prevenção, drogas, adolescentes, mulheres, apoio psicológico aos portadores. São Paulo: Summus Editorial, 1992. p.19-22.

Tipo de Produção: Capítulo de Livro

Instituição Envolvida: Reflexão teórica

Tema Principal: A morte / causa mortis

Objeto do texto: A morte e as formas de morrer

Objetivo do texto: Falar da morte, não em geral, em particular, a morte do aidético, a que se anuncia.

Linha Teórica: Não explicitada. 
Conclusões: Não há, só uma reflexão no sentido de "graduar" que tipo de morte é preferível: a que se anuncia, ou a traiçoeira que chega pelas costas, sem avisar, ou brincalhona que vai e vem, ou a perversa, lenta que vai chegando com as rugas dificultando o gozo, toma o braço do senil e fica ao lado do entrevado.

Sugestões: Não há

Indicação Bibliográfica: Não foi encontrada referência de interesse para o presente estudo.

\section{FICHA TÉCNICA - TEXTO 12}

Autor: Júlio de Mello Filho

Instituição: Hospital Universitário Pedro Ernesto (HUPE) da Universidade Estadual do Rio de Janeiro

Local: Rio de Janeiro

Ano: 1992

Título: Aids: o doente, o médico e psicoterapeuta

Tipo de Produção: Capítulo de Livro

Fonte: Mello Filho J de e col. Psicossomática Hoje. Porto Alegre: Artes Médicas; 1992. p.299312.

Instituição Envolvida: Setor de Psicologia Médica do Serviço de Psicologia Médica e Psiquiatria do HUPE

Tema Principal:

a) Atendimento em psicoterapia a pacientes HIV positivo.

b) Equipe multiprofissional.

c) Relação médico-paciente frente à nova doença.

Sub-temas:

a) Os pacientes homossexuais/as mulheres/ os usuários de droga.

b) Atitudes e sentimentos dos profissionais: rejeição, pânico, hostilidade, atuação, resistência, negação, preconceito, fantasia de infecção.

c) Paciente terminal, morte.

Objeto do Texto: Refletir sobre o desafio de fazer psicoterapia com pacientes de aids e acompanhálos na trajetória da doença até a morte, conforme a sua necessidade, no ambulatório, na enfermaria ou mesmo em suas casas.

Conceitos abordados: self, holding, paradoxo, amor objetal, amor narcísico, negação perversão, formação reativa, contratransferência, masoquismo, onipotência, luto, ato falho.

Objetivo do Texto: Relatar a experiência. Descrever as características da instituição, dos pacientes, dos profissionais.

Linha Teórica: Freudiana, Winnicottiana. 
Conclusões: Há algumas reflexões importantes sobre o morrer e uma delas é a de que “... neste período terminal ninguém melhor do que o próprio paciente para servir de bússola para indicar a melhor forma de ajudá-lo, devendo ser respeitado em suas defesas e possibilidades. [Para isso é necessário] (...) uma comunhão de mentes que nos permita penetrar nos abismos psíquicos onde se aloja o fantasma da morte dentro de cada um de nós. É destas profundezas do existir que iremos retirar a sapiência, a lucidez e o senso de realidade que irão nos ajudar neste trabalho" (p.311).

Sugestões: MELLO FILHO coloca uma questão: se houve a necessidade de uma doença como a aids para que as pessoas possam tomar consciência, das múltiplas verdades sobre a sexualidade humana, sobre as práticas de saúde (como o problema das transfusões), sobre a realidade dos tóxicos e sobre o problema das viroses que de várias formas vem extirpando parte de nossa existência (p.312).

Indicação Bibliográfica: Fiuza H. Aids a doença do medo. Radis. 1987, p.51.

\section{FICHA TÉCNICA - TEXTO 13}

Autor: Amauri Queiroz

Instituição: Hospital Universitário Clemente Fraga Filho, da Universidade Federal do Rio de Janeiro.

Local: Rio de Janeiro

Ano: 1992

Título: Aids, aspectos psicossomáticos.

Tipo de Produção: Capítulo de Livro

Fonte: Mello Filho J de e col. Psicossomática Hoje. Porto Alegre: Artes Médicas; 1992. p.313-19.

Instituição Envolvida: Serviço de Psicologia Médica e Saúde Mental da HUCFF da UFRJ

Tema Principal:

a) Preparo dos profissionais de saúde para lidar com os pacientes e seus familiares.

b) Relação médico-paciente, modalidades de atendimento.

c) Comunicação do diagnóstico.

Sub-temas:

a) Onipotência dos médicos frente à incurabilidade.

b) Nosografia psiquiátrica - reações depressivas, reações paranóides, reações maniformes, c) reações histeriformes.

d) Modificações no setting.

e) Papel das religiões.

Objeto do Texto: Trata-se de uma reflexão sobre a experiência do atendimento a pacientes de aids desde os primórdios da doença, quando havia desconhecimento a respeito dos problemas decorrentes dela, até a organização do serviço frente à nova demanda.

Conceitos abordados: inconsciente, reações psicopatológicas. 
Objetivo do Texto: Relatar a experiência de 2 anos de atendimento dos primeiros casos de aids. Refletir sobre o trabalho com o paciente terminal.

Linha Teórica: Freudiana

Conclusões: Importante que os profissionais vençam a barreira do medo para lidar com os pacientes e o diálogo seja estabelecido e mantido. O psicoterapeuta só deve se comprometer com o atendimento se estiver disposto a acompanhar os pacientes em possíveis circunstâncias especiais, podendo até abandonar os habituais preceitos éticos e de setting para atendê-los.

A aids é um desafio à sociedade em geral.

Sugestões: Fazer um trabalho de alargamento social junto às famílias, às empresas, às escolas, às organizações religiosas para abranger um maior número de pessoas para aumentar a informação e a prevenção.

Indicação Bibliográfica: Souza, ARN. A reflexão do saber sobre a impotência - SIDA/AIDS, uma experiência em psicologia médica. Dissertação de Mestrado - Instituto de Psiquiatria, UFRJ, 1988.

\section{FICHA TÉCNICA - TEXTO 14}

Autor: Alícia Navarro Dias de Souza

Instituição: Hospital Universitário Clementino Fraga Filho da Universidade Federal do Rio de Janeiro.

Local: Rio de Janeiro

Ano: 1992

Título: Grupo de reflexão multiprofissional em aids: uma estratégia em psicologia médica Tipo de Produção: Capítulo de Livro

Fonte: Mello Filho J de e col. Psicossomática Hoje. Porto Alegre: Artes Médicas; 1992. p.320-4. Instituição Envolvida: Hospital geral/Serviço de Psicologia Médica/Serviço de Doenças Infecciosas do H.U.C.F.F.

\section{Tema Principal:}

a) Ampliação do modelo médico de atendimento ao considerar a dimensão social da doença.

b) Equipe multiprofissional na instituição assistencial, promovendo grupo de reflexão para favorecer a integração da equipe.

c) Transferência/contratransferência;

d) Função psicoterápica diferenciada na relação profissionais de saúde-paciente.

Objeto do Texto: Refletir sobre a experiência de enfrentar o desconhecimento associado à vivência do desafio e do controle da própria ameaça de morte que os profissionais de saúde se submetem no risco da infecção. Identificação com a discriminação e com outros estigmas associados à aids. Conflito entre o prestígio institucional e a impotência terapêutica (ambivalência).

Conceitos abordados: defesa maníaca, negação, impotência. 
Objetivo do Grupo: A produção de significações que se dá no grupo

Objetivo do Texto: Analisar a questão da contribuição da psicanálise ao campo dinâmico da relação profissionais de saúde-paciente no contexto de um hospital geral.

Linha Teórica: BALINT/BLEGER/FREUD/LUCHINA/BION.

Conclusões: O grupo de reflexão multiprofissional baseado no referencial teórico utilizado contribuiu para o aumento do conhecimento dos profissionais e, através das trocas, possibilitou a elaboração dos conflitos emergentes da tarefa assistencial a pacientes com aids, bem como das relações conflitivas entre os diferentes profissionais que integram a equipe de saúde. Isso só foi possível graças à produção de significações que esse tipo de estratégia interpretativa favorece, e por meio da qual se estabelece uma maior integração nas trocas simbólicas no grupo multiprofissional. Existe uma intensificação de conflitos decorrente da aids na assimetria da relação médico-paciente. Esses conflitos têm implicações no tratamento individual, mas evidenciam também a oposição entre individual e coletivo, quando a coletividade que discrimina é a mesma que tem que criar as condições para o atendimento terapêutico (a equipe multiprofissional). É um desafio para o conhecimento médico que tem que dar conta também da dimensão existencial do atendimento.

Sugestões: não há

Indicação Bibliográfica: Souza, ARN. A reflexão do saber sobre a impotência: SIDA/AIDS, uma experiência em psicologia médica. Rio de Janeiro, 1988. Dissertação de Mestrado. Instituto de Psiquiatria UFRJ.

\section{FICHA TÉCNICA - TEXTO 15}

Autor: Esdras Guerreiro Vasconcellos

Instituição: Instituto de Psicologia da Universidade São Paulo.

Local: São Paulo

Ano: 1992

Título: Aids e morte psicossomática

Fonte: Em tempos de aids: viva a vida: sexo seguro, prevenção, drogas, adolescentes, mulheres, apoio psicológico aos portadores. São Paulo: Summus; 1992, p.32-7.

Tipo de Produção: Capítulo de livro

Instituição Envolvida: Não explicitada. O texto é baseado no trabalho de psicoterapia de grupo com portadores do vírus HIV e doentes de aids.

Tema Principal: Aids e morte psicossomática.

Sub-temas:

a) Apoio psicológico versus intervenção.

b) Narcisismo e onipotência do terapeuta.

Objeto do Texto: Morte/morte psicossomática.

Conceitos abordados: narcisismo, onipotência e inconsciente. 
Objetivo do Texto: Refletir sobre a morte como resultante de uma dinâmica desencadeada pelo inconsciente humano, tornando o homem o autor da sua própria morte.

VASCONCELLOS evidencia que “... com exceção dos acidentes involuntários, a morte é, sempre, psicossomática" (p.35).

\section{Linha Teórica: FREUD e GRODDECK}

Conclusões:

a) "É o inconsciente do ser humano quem dispõe de forças decisivas sobre a vida e a morte, através de sua dinâmica" (p.35).

b) $\mathrm{O}$ autor não nega que o órgão adoece e coloca em risco a harmonia funcional de todo o organismo, mas afirma que esse órgão só desencadeia o processo patológico e/ou fatal quando o inconsciente humano resolve romper com o equilíbrio homeostático. Confirma com uma citação de FREUD: "o organismo quer morrer, mas à sua maneira" (FREUD citado por VASCONCELLOS 1992, p.35).

c) "Cada ser humano tem seus motivos pessoais e individuais para morrer. Morre em virtude deles, não em virtude de vírus e patologias. Ainda que elas, inegavelmente, existam” (p.36).

d) “... a relação social e afetiva é o fator mais central do processo de vida e morte. A perda de amor é um fenômeno mortal para a psique humana. Um ferimento narcísico irreparável. Ferido mortalmente pela perda, o homem tenta, narcisicamente, defender-se da fatalidade que o envolve. É aí que ele mobiliza tanta energia tentando imunizá-la, neutralizá-la, que termina por adoecer. Outros não resistem, morrem" (p.36). É o que o autor denomina "introversão da relação objetal libidinosa".

Muitos indivíduos quando tomam conhecimento de sua soropositividade passam a relacionar-se apenas consigo mesmos enquanto abominam seu corpo erógeno. "O ser humano resolve com a enfermidade e a morte o conflito entre a perda do outro e a necessidade de ser amado (...). Narcisismo é o desejo de ser desejado. O mais desejado. Necessitamos disso para que possamos nos sentir completos, perfeitos" (p.36).

e) A aids requer, para sua desmitificação, que se aceite, sem pavor, a morte que ela provoca. Isto se dará através da superação do preconceito social e do próprio preconceito. Os que determinarem morrer e aqueles cujo ego não tenha mais forças de resistência sobre os processos destruidores inconscientes sucumbirão.

Sugestões:

a) Os psicoterapeutas conscientizarem-se do impulso de onipotência e dos seus limites como profissionais e como pessoas, para entenderem que não se salva ninguém da morte;

b) Compreenderem que todo ser humano é o único autor de sua morte, já que ela se processa através da dinâmica inconsciente, individual, inesgotável de cada um.

Indicação Bibliográfica: Não foi encontrada referência de interesse para o presente estudo. 


\section{FICHA TÉCNICA - TEXTO 16}

Autor: Eliane A. Costa Dias

Instituição: Divisão de Psicologia do Instituto Central do Hospital das Clínicas da Faculdade de Medicina da USP

Local: São Paulo

Ano: 1993

Título: O profissional de saúde mental frente à realidade aids: algumas considerações

Fonte: Revista de Psicologia Hospitalar do Hospital das Clínicas de São Paulo. 1993; 3(1): 1013.

\section{Tipo de Produção: Artigo}

Instituição Envolvida: Divisão de Clínica de Moléstias Infecciosas e Parasitárias do ICHC

Tema Principal: Profissional de saúde mental frente à aids. Irracionalidade que marca os discursos e as práticas acerca da aids. Existência de um campo imaginário, social e individual terrorífico e persecutório que se sobrepõe à aids real.

Sub-temas: Eclosão das três questões humanas: morte, contágio, sexualidade derivada da aids:

a) A morte como inominável (interditos, silêncios): impossibilidade do homem moderno conviver com a finitude, com o limite enquanto condição própria de sua existência. A aids traz, de maneira súbita e violenta, a evidência da morte, da impotência, do princípio da realidade.

b) Sexualidade: a aids denuncia as ambivalências e contradições de uma sociedade que acreditava ter realizado a revolução sexual.

Objeto do Texto: Repercussões sociais, psicológicas, culturais e políticas da aids.

Conceitos: Identidade, sinistro, princípio da realidade e impotência.

Objetivo do Texto: Discutir acerca das repercussões sociais e psicológicas da aids e refletir sobre o papel do profissional de saúde mental nesta realidade.

\section{Linha Teórica: Freudiana}

Conclusões: A aids obriga a entrar em contato com a morte, dor, sofrimento, impotência, sexualidade, identidade, medos e fantasias.

São muitas as perdas provocadas pela aids que o portador ou doente vivencia:

- perda do projeto de vida;

- perda da identidade corporal, temporal e social;

- perda da autonomia e da privacidade sobre a identidade social;

- perda das relações afetivas.

A doença expõe uma identidade transgressora. Provoca a eclosão de conflitos profundos e anteriores, que expostos, são carregados de julgamentos e valorização públicas, sociais e morais.

$\mathrm{Na}$ maioria das vezes, segundo DIAS, a aids ocorre em personalidades frágeis, narcísicas, marcadas, por uma estrutura perversa que promove a recusa da realidade.

A assistência psicológica num primeiro momento deve possibilitar escuta e continência para as 
vivências do paciente (extensiva aos seus familiares e parceiros) que lhe permita discriminar, nomear e elaborar suas angústias e fantasias e a maneira individual pela qual seu mundo mental reage à nova realidade de ser soropositivo.

O profissional deve perceber também, seus próprios fantasmas e representações, seus valores e preconceitos. Identificando os sentimentos ambivalentes e a ansiedade frente à questão da morte, aos limites e impotência de sua ação (quebra do ideal de cura e de poder do ato médico), ao medo contágio, aos valores a respeito da sexualidade, etc., estará mais possibilitado de lidar com os próprios conflitos, diminuindo o nível de ansiedade paralisador e desestruturante.

Sugestões: O psicólogo na instituição hospitalar não deve “... ocupar o lugar de quem pode obliterar a ruptura e as feridas provocadas pela aids, o lugar ilusório do profissional encarregado da angústia (...) sua possibilidade de sobrevivência reside exatamente em escapar a essa armadilha criada pelo desejo de quem oferece escuta e a possibilidade de NOMEAR, de transformar em palavras o que é vivido por todos os personagens envolvidos neste campo" (p.13) (destaque da autora).

Indicação Bibliográfica: Não foi encontrada referência de interesse para o presente estudo.

\section{FICHA TÉCNICA - TEXTO 17}

Autor: Célia Klouri

Instituição: Instituto de Infectologia Emílio Ribas

Local: São Paulo

Ano: 1993

Título: Vivendo entre duas mortes: drogadição e aids.

Fonte: Revista de Psicologia Hospitalar do Hospital das Clínicas de São Paulo. 1993, 3(1): 4-9.

Tipo de Produção: Artigo

Instituição Envolvida: I.I. Emílio Ribas.

Tema Principal: Drogadição e aids

Objeto do Texto: Drogadição e aids - Estudo a partir de entrevistas com usuários de drogas infectados pelo HIV.

Conceitos abordados: princípio do prazer, pulsão de morte, castração, narcisismo, angústia, gozo, mecanismos de defesa.

Objetivo do Texto: Descrever sob a ótica psicanalítica, a dinâmica psíquica do drogadito e sua reação frente ao diagnóstico de aids.

Linha Teórica: Freudiana, Lacaniana.

Conclusões:

A problemática do narcisismo aparece nos relatos. A pessoa funcionava, internamente, buscando uma satisfação narcísica, dirigida só pelo princípio do prazer, estando o mesmo a serviço da pulsão de morte. 
“ABADI (1992) assinala a semelhança da droga com o objeto fetiche, cuja função é negar uma ausência. OLIVENSTEIN (1990) considera que, no início, a droga se instala no lugar de uma falta arcaica insuportável, proporcionando prazer. (...) [KLOURI evidenciou] uma acentuada dificuldade em reconhecer a falta, a perda, ou seja, a castração e angústia relacionada a ela. Castração (...) como uma força separadora inconsciente, que implica em uma perda ou uma falta, e impõe ao ser humano um limite ao seu gozo absoluto, a sua onipotência imaginária" (p.7).

A busca desenfreada do prazer se sobrepõe às conseqüências destrutivas e a aids é mais uma conseqüência autodestrutiva que é negada de forma onipotente, pois: ou é ignorada, ou os usuários de droga acreditam que não serão atingidos.

A partir do diagnóstico de aids houve uma mudança no funcionamento interno dos pacientes entrevistados, havendo uma maior aproximação com a realidade, através da aderência ao tratamento médico, a preocupação com a saúde e a preservação da vida. Até então tinham a fantasia de serem imortais ou de que, se morressem de overdose, seria uma morte prazerosa, heróica, triunfal. Com a aids a morte toma outra forma, pela debilitação, preconceito e longevidade da doença. Aparece o temor do desfiguramento e degradação que a doença provoca que os leva a desejar morrer antes que isso ocorra, para não se defrontarem com a ferida narcísica e a angústia de castração. Por não suportarem essa angústia, recorrem a antigos mecanismos como a negação da morte e a onipotência.

A aids passou a representar uma ameaça concreta somente depois que esses indivíduos já estavam infectados.

Sugestões: Programas de prevenção da aids devem ser acompanhados de programas de prevenção e tratamento do uso de drogas que levem em conta a dinâmica psíquica que a autora descreveu.

Indicação Bibliográfica: Não foi encontrada referência de interesse para o presente estudo.

\section{FICHA TÉCNICA - TEXTO 18}

Autor: Maria Isolina Baptista Marques

Instituição: Pontifícia Universidade Católica de São Paulo - Programa de Pós-Graduação em Psicologia Clínica

Local: São Paulo

Ano: 1993

Título: No teatro da vida o espectro da morte: uma investigação sobre a vida mental do paciente aidético.

Fonte: -

Tipo de Produção: Tese de Doutorado

Instituição Envolvida: Hospital do Servidor Público Municipal - Clínica de Hematologia

Tema Principal:

a) Vida mental do paciente com aids, no caso, funcionários públicos municipais infectados: 
heterossexuais, homossexuais, bissexuais, usuários de drogas (categorias de exposição).

b) Reações emocionais à doença.

Objeto: Vida mental do paciente com aids.

Conceitos abordados: posição depressiva, posição esquizo-paranóide, relações de objeto, pulsão de vida, pulsão de morte.

Objetivo: Investigar a vida mental dos pacientes, suas vivências relacionadas ao momento do diagnóstico às circunstâncias da infecção pelo vírus, às mudanças de estilo de vida, ao relacionamento pregresso e atual com outras pessoas, às expectativas de vida e projetos para o futuro. Relacionar estas dinâmicas mentais com a sintomatologia orgânica apresentada por tais pacientes.

\section{Linha Teórica: Kleiniana}

Conclusões: Fundamentando os resultados nas formulações teóricas de Melanie Klein (1935, 1940, 1946, 1952) a autora conclui que: as vivências apresentadas pelos pacientes foram, em sua maioria (em 16 pacientes), ancoradas na posição depressiva, observando-se, também, vivências ancoradas na posição esquizo-paranóide (em 4 pacientes). A autora associa as posições aos estados sintomático e assintomático de evolução da doença, na primeira posição e assintomático, na segunda posição. (Utilizou-se dos grupos I, II, III, IV-A, IV-C e IV-D para classificar os estados de evolução da doença dos sujeitos pesquisados).

As configurações mentais encontradas foram:

a) "Pacientes com angústias depressivas e reações melancólicas, com predomínio das defesas depressivas, maníacos e esquizo-paranóides e relações de objeto mais estáveis" (p.100). São os pacientes com infecções oportunistas, com sintomas constitucionais, sem sintomas psiquiátricos.

b) "Pacientes com angústias depressivas e esquizo-paranóides, com predomínio das defesas maníacas e esquizo-paranóides..." (p.101) podem, às vezes, apresentar vivências melancólicas. As relações de objeto tendem a ser mais instáveis. Os pacientes apresentavam Sarcoma de Kaposi, havendo alguns assintomáticos sem sintomas psiquiátricos.

c) "Pacientes com angústias e defesas de natureza esquizo-paranóide e relações de objeto que podem se apresentar tanto estáveis, quanto instáveis" (p.101). Nesse grupo, estão os pacientes assintomáticos para o HIV com sintomas psiquiátricos.

Os estados emocionais dos pacientes são influenciados pela desvitalização provocada pelo HIV, desencadeando-se, em alguns, distúrbios psicopatológicos e, em outros, vivências depressivas.

MARQUES faz a suposição de que a dinâmica envolvida nas vivências das pulsões de vida e de morte favorece a instalação de doenças oportunistas ou de cânceres secundários no organismo dos pacientes, interferindo no tempo de sobrevida.

"Pacientes assintomáticos, com vivências de natureza 'borderline' ou psicótica, preservam-se por muito mais tempo da doença orgânica do que aqueles que ao serem infectados não apresentam tais distúrbios. Supomos que estes pacientes transferem a ameaça de morte orgânica para uma ameaça 
de morte a nível mental” (p.102).

"Os pacientes com sintomas constitucionais (grupo IV-A), assemelham-se em seus sintomas orgânicos (...) aos pacientes psiquiátricos, com depressões de caráter funcional...” (p.102).

"As mulheres apresentam, regra geral, maior sobrevida do que os homens...", independente do estágio da doença.

A autora, embora não tendo composto sua amostra por pacientes infectados por transfusões sangüíneas, conjetura “... que estariam provavelmente sujeitos às mesmas vicissitudes mentais que os demais pacientes aidéticos" (p.103).

Sugestões: MARQUES considera que seus achados referem-se não só aos pacientes pesquisados (doentes), mas a todo e qualquer ser humano e que se pode, em princípio, validar essas conclusões.

Indicação Bibliográfica: A autora ressalta que em seu levantamento bibliográfico (BIREME, Bibliotecas do Hospital Emílio Ribas e Centro de Referência e Treinamento de aids de 1986 a 1993) não encontrou nenhum título relacionado à pesquisa psicanalítica e aids.

\section{FICHA TÉCNICA - TEXTO 19}

Autor: Joel Birman

Instituição: Universidade Estadual do Rio de Janeiro

Local: Rio de Janeiro

Ano: 1994

Título: A sexualidade entre o mal e as maledicências

Fonte: Loyola, M.A. (org.) Aids e sexualidades. Rio de Janeiro: Relume-Dumará/UERJ, 1994, p.109-15.

Tipo de Produção: Capítulo de livro

Instituição Envolvida: Trata-se de uma reflexão teórica

Tema Principal: Sexualidade e imaginário social

Sub-temas:

a) Erotismo/homossexualidade

b) Imaginário obsessivo-compulsivo

c) Fobia de contato

d) Morte biológica/morte simbólica, erógena e política

e) Norma sexual

f) Desejo - pluralidade de desejo

Objeto: A sexualidade entre o mal e as maledicências.

Conceitos abordados: gozo, estrutura obsessiva, desejo, sexualidade.

Objetivo: Discutir e refletir como a aids inscreve a figura da morte na experiência do gozo, renovando antigos temores fundamentais, constituídos no imaginário ocidental pelo Cristianismo, apresentando-se (a morte) como o Outro que se interpõe no cenário do prazer, devorando a 
experiência erógena.

Fazer uma leitura crítica do remanejamento de forças: de um lado a ética da pós-modernidade formada pelas conquistas dos direitos sexuais e direitos às diferenças subjetivas incorporadas aos direitos sociais e, de outro lado, o evidente recuo neste campo e uma relativização das conquistas.

Linha Teórica: Lacaniana

Conclusões: São incluídas neste item algumas considerações do autor:

a) Evitar o contato até mesmo com o anúncio da morte, como se isto pudesse atualizar o acontecimento da perda da vida. Os rituais de purificação ocupam o lugar de afastar o sujeito e o horror à ameaça da morte.

b) “... a figura da morte é a fonte inesgotável para a montagem de terroríficos espetáculos perversos" (p.110). A morte como doença e epidemia é antiga (desde a lepra e a peste) e retoma o discurso da medicina social e práticas de saúde pública a favor de uma estratégia de manutenção da vida e do espaço social, que autoriza “... uma política de exclusão social dos doentes e dos sujeitos que seriam potencialmente enfermos, pois se inserem nos denominados grupos de risco" (p.111).

c) BIRMAN diferencia a aids das clássicas doenças venéreas. Embora ambas estabeleçam relações entre a sexualidade e a morte, as últimas são conseqüência da volúpia sexual, mas fazem parte da norma sexual heterossexual não questionada, enquanto que na primeira, a morte é conseqüência do desejo sexual, da escolha sexual homossexual, para a qual já há a penalidade do sujeito no imaginário social e psíquico (porque foge à norma). A aids explicita o pluralismo do desejo com a constituição de outra norma sexual, e a suspensão de qualquer interdição em face do desejo homossexual. "... com a aids a criminalização dos homossexuais pelo genocídio da humanidade e a sua medicalização massiva se coloca novamente em cena” (p.113).

c) Na mesma página, o autor considera: “...a problemática da sexualidade é o fio condutor para a indagação de algumas das questões cruciais que a aids coloca na atualidade". Ela coloca em jogo os destinos da sexualidade na cultura do ocidente neste final de século e, por se apresentar como uma epidemia e doença mortal, transcende o universo dos cuidados e da assistência médica, revelando a ética e alguns dos valores que subjazem à nossa tradição cultural. Revela-se também os “... prazeres possíveis e direitos desejáveis (...) amores permitidos e (...) enlaces interditos” (p.114).

$\mathrm{O}$ autor relembra que o discurso freudiano e a psicanálise estão aí para dizer sobre a natureza do desejo e sobre a sua legitimidade, permitindo uma compreensão dos mesmos.

d) Assim, a aids recoloca a “... multiplicidade de leituras sobre o corpo que é preciso reconhecer (...) para nos indagarmos sobre os dispositivos sanitários [neste campo] e sobre as diferentes perspectivas de intervenção clínica"(p.114). E continua: "A sexualidade e o universo macabro constituído sobre a aids revelam, de maneira eloqüente, que o corpo não é apenas um suporte físico (...) [mas marcado pela subjetividade e pelas diferentes representações do sujeito constituídas] por diferentes estratégias lingüísticas, políticas e sociais, que possibilitam que de um organismo se produza um corpo erógeno" (p.114). É a erogeneidade que dá a enunciação do estatuto simbólico 
do corpo que está em questão nos discursos sobre a aids.

Sugestões: poder discutir as linhas de força que estão em jogo em torno da aids e da sexualidade é o que possibilitará a construção do futuro pela transposição dos obstáculos colocados no presente. Indicação Bibliográfica: Não foi encontrada referência de interesse para o presente estudo.

\section{FICHA TÉCNICA - TEXTO 20}

Autor: Maria Cristina de Jesus Costa

Instituição: Pontifícia Universidade Católica de São Paulo - Faculdade de Psicologia

Local: São Paulo

Ano: 1994

Título: Crianças com aids: a representação mental da doença.

Tipo de Produção: Trabalho de Conclusão de Curso - Graduação

Fonte: -

Instituição Envolvida: Centro de Convivência Infantil "Filhos de Oxum" - Casa Abrigo para crianças portadoras do vírus HIV

Tema Principal: Representação que a criança tem da doença.

Sub-temas:

a) Angústias

b) Medos

c) Sentimentos de perda

d) Ameaça de morte

e) Desenhos-estória como instrumento de avaliação

Objeto do texto: Estudo acerca da representação que a criança com aids possui da doença.

Conceitos: mecanismos de defesa, dinâmica psíquica, representação mental.

Objetivo: Conhecer as fantasias e medos que a criança desenvolve, as emoções despertadas e a forma como ela lida internamente com essas emoções. Avaliar quais mecanismos de defesa a criança utiliza, quais as forças internas de que abre mão, quais as formas de comunicação, em termos de mensagens, que ela envia e que sinais se manifestam em seu comportamento.

Linha Teórica: Não explicitada. Porém, elabora uma análise psicodinâmica e, pelos os desenhos serem baseados na técnica de Walter TRINCA, provavelmente, a linha é Kleiniana.

Conclusões:

a) Crianças desta instituição encontram-se fragilizadas e inseguras frente ao ambiente externo, visto como ameaçador e frente ao qual se utilizam uma defesa no contato social.

b) Dificuldade de lidar com os conflitos internos, com bloqueio da fantasia para elaboração dos mesmos.

c) A fragilidade e a vulnerabilidade causam muita angústia e tristeza frente à impotência no controle externo. 
d) COSTA levanta a hipótese de haver uma carência afetiva que contribui para a busca de afeto e fragilidade das crianças.

e) Ambivalência de sentimentos frente às "figuras maternas", cuja presença é restritiva frente às necessidades das crianças.

f) Representação mental da doença é particular, proveniente de sua história de vida e da instituição que as abriga.

g) Ambiente externo ameaçador e destrutivo é projetado na efetivação da doença que possuem.

h) Não são informadas de que são portadoras então, quando alguém adoece e é internado, acentuam-se as fantasias acerca do que acontecerá com elas. Além disso, há a dupla mensagem: "não são doentes", mas são tratadas como se fossem (p.29). Quem passa mal e vai para o hospital não volta mais. O que aconteceu?

i) Reagem de forma agressiva ao mundo, parecendo ser esta a única forma que aprenderam a se relacionarem com ele.

Sugestões:

a) A autora aspira a que sua contribuição mobilize interesses científicos e humanos, para que o assunto possa ser ampliado e desenvolvido no seu meio profissional.

b) Sugere que a questão de comunicação do diagnóstico às crianças seja analisada com maior profundidade, pois considera que o não dizer pode acentuar fantasias e angústias, não amenizando o conflito.

Indicação Bibliográfica: Não foi encontrada referência de interesse para o presente estudo.

\section{FICHA TÉCNICA - TEXTO 21}

Autor: Renata Udler Cromberg

Instituição: Departamento de Psicanálise - Instituto Sedes Sapientiae

Local: São Paulo

Ano: 1994

Título: O fantasma do fim da história e a positividade do princípio feminino.

Tipo de Produção: Artigo

Fonte: Revista Psicologia da USP, 5 (1/2): 197-219

Instituição Envolvida: Consultório particular

Tema Principal ${ }^{*}$ : Psicanálise, História, Sexualidade, Fascismo, Aids.

Sub-Tema:

Aids e o fantasma da morte sinistra

Objeto: As experiências-limite de uma lógica que vê na modernidade iluminada pela racionalidade científica, tecnológica e política, a única saída para a humanidade. A aids seria um dos impasses 
dessa lógica e a queda do fantasma linear da história.

Conceitos: Pulsão de morte, Eros, melancolia, racionalização.

Objetivo: “... abordar (...), sob a forma de conjecturas, (...) a dimensão imaginária da aids - essa vertente da morte que aparece ligada à sexualidade, essa sexualidade vivida como mortífera" (p.204-5).

Linha Teórica: Cita vários autores durante o texto todo, desde o próprio FREUD até autores mais contemporâneos como: Françoise DOLTO, Renato MEZAN, J. KRISTEVA, S. LECLAIRE e D. WINNICOTT.

Conclusões: Não são conclusões, são conjeturas:

CROMBERG reflete “... sobre as circunstâncias psíquicas em que se adquire um vírus que fragiliza as defesas orgânicas. Sob que estado de fragilização das defesas psíquicas se encontra quem adquire aids?" (p.206)

$\mathrm{Na}$ seqüência, aborda a questão das "neo-sexualidades", trabalho desenvolvido por Joyce MACDOUGALL para embasar sua indagação acerca do que ocorre com o ser humano através da sexualidade.

Parece haver, segundo ela, um apagamento da diferença e uma "liquidificação" de si, que apaga o próprio corpo. "O que me intriga é este externo, onde a não-intervenção de um princípio vital de desligamento, da pulsão de morte como o que faz emergir o desejo e a diferença, leva à dissolução das fronteiras corporais de maneira viral e epidêmica, levando Eros a uma circulação desenfreada onde a pulsão parcial se desloca e se movimenta ao máximo e num ritmo cada vez mais regressivo. Sem dúvida, ela dará muito que pensar e rever a respeito da própria sexualidade humana" (p.2067).

Cita um caso supervisionado em que o pênis do paciente era desconsiderado, talvez, porque “... ele nem sequer soubesse ainda, psiquicamente, se tinha um corpo, e nem suspeitasse da melancolia que se escondia sob suas requintadas racionalizações" (p.207).

Sugestões: não há

Indicação Bibliográfica: Não foi encontrada referência de interesse para o presente estudo.

\section{FICHA TÉCNICA - TEXTO 22}

Autor: Cláudio Vital de Lima Ferreira

Instituição: Hospital de Clínicas da Universidade Federal de Uberlândia - MG

Local: Uberlândia - MG

Ano: 1994

Título: O paciente diante da aids e da morte

Tipo de Produção: Capítulo de livro

\footnotetext{
* Trata-se de um artigo dividido em 4 seções dentre as quais, a seção 3 trata da AIDS e é sobre ela que será
} 
Fonte: Ferreira CVL. Aids e vida: um estudo clínico-psicanalítico com pacientes HIV. São Paulo: Lemos, 1994. Aspectos psicodinâmicos da aids; p.53-8.

Instituição Envolvida: a mesma

Tema Principal: A relação médico-paciente/confidencialidade. Fases psicológicas vividas pelo paciente HIV.

Sub-temas:

a) Mecanismos de defesa utilizados contra a angústia da morte.

b) Homossexualidade.

Objeto do Texto: Discussão de aspectos relacionados ao enfrentamento da doença pelos profissionais de saúde e às reações dos pacientes.

Conceitos abordados: mecanismos de defesa, angústia, transferência e contratransferência.

Objetivo do Texto: Refletir sobre os temas apontados acima no contexto do atendimento clínico dos pacientes soropositivos.

Linha Teórica: Freudiana

Conclusões:

a) $\mathrm{O}$ autor constatou a utilização do mecanismo do desligamento com a função de negação implícita de morrer, como forma de enfrentar a angústia de morte.

b) As conseqüências da doença podem ser melhor toleradas se existir apoio social que fortaleça as condições emocionais.

c) A aids restitui ao indivíduo a responsabilidade pela sua saúde, antes delegada ao médico, que agora não dispõe da cura da doença.

d) O suicídio é, algumas vezes, adotado como alternativa pelo paciente, que, incapaz de cuidar de si mesmo, opta pela “... concretização da castração sob a forma de autodestruição" (p.54).

e) O autor utiliza a conceituação de NICHOLS (1985) que descreve 5 fases pelas quais o paciente HIV positivo passa: negação do diagnóstico; sentimento de raiva, culpa e autopiedade; aceitação do diagnóstico; tristeza, ansiedade e depressão e, por fim, a preparação para a morte. A psicoterapia pode auxiliar o paciente em todas as fases, desde que se instale uma atitude transferencial positiva por parte dele e da família.

f) Decorre da aids uma devassa na intimidade dos pacientes, fazendo-se necessária a confidencialidade, principalmente no que se refere à escolha sexual (em geral a homossexualidade) para evitar a marginalização social.

Sugestões: não há.

Indicação bibliográfica:

Costa LPM, Mello Filho J de. Atendimento psicoterápico em um caso de aids. Inform. Psiq. 1988; $7(1): 20-5$.

feita a análise (p.204-207). 
Costa LPM, Lima CQ, Mello Filho J de. Grupoterapia com pacientes HIV positivos (Aids). Inform. Psiq. 1989; 8(3): 97-103.

Cassorla RMS. Lidando com aids: uma experiência de supervisão de equipe multiprofissional. In: Cassorla RMS (coord.). Da morte: estudos brasileiros. Campinas: Papirus; 1991. p.231-41.

Oliveira Neto MX. O paciente homossexual HIV positivo (Aids) e a morte. J. Bras. Psiq. 1990; 39(5): 244-9.

\section{FICHA TÉCNICA - TEXTO 23}

Autor: Cláudio Vital de Lima Ferreira

Instituição: Hospital de Clínicas da Universidade Federal de Uberlândia - MG

Local: Uberlândia - MG

Ano: 1994

Título: Aspectos Psicodinâmicos da aids.

Tipo de Produção: Capítulo de livro

Fonte: Ferreira CVL. Aids e vida: um estudo clínico-psicanalítico com pacientes HIV. São Paulo: Lemos, 1994. Aspectos psicodinâmicos da aids; p.59-62.

Instituição Envolvida: a mesma

Tema Principal: Aspectos psicodinâmicos da aids.

Sub-temas:

Negação, luto e melancolia.

Objeto do Texto: Reação do paciente de aids ante a morte.

Objetivo do Texto: Refletir sobre os aspectos psicodinâmicos evidenciados no paciente com HIV/AIDS.

Linha Teórica: Freudiana

Conclusões: "As alternativas freqüentemente seguidas pelos pacientes com aids, como reação à perda, são a negação, o luto ou a melancolia" (p.59).

FERREIRA analisa as formas com as quais o sujeito pode lidar com a morte que é uma realidade que a aids apresenta para ele.

Na negação, a realidade não é percebida, não é contatada. A fantasia restitui o que se perdeu. "É como se nada estivesse acontecendo" (p.60). É um não enfrentamento da realidade.

No luto - o autor está usando a conceituação de FREUD a esse respeito - libera-se o investimento da parte morta, do objeto que se perdeu, e esse é dirigido a outro objeto.

No caso da aids, o novo objeto pode ser o tratamento, um investimento na melhoria da qualidade de vida, dos relacionamentos, etc. É uma saída positiva mesmo levando-se em conta os limites impostos pela aids.

Citando FREUD, FERREIRA considera a melancolia, cujos “... traços mentais distintivos são um desânimo profundamente penoso, a cessação de interesse pelo mundo externo, a perda da 
capacidade de amar, a inibição de toda e qualquer atividade e uma diminuição dos sentimentos de auto-estima..." (FREUD 1917, p.726, citado por FERREIRA 1994, p.61).

No paciente com HIV isto se refletiria em se castigar pelas múltiplas culpas: da infecção, das práticas sexuais promíscuas, dos comportamentos ilícitos como o uso de drogas, etc, podendo culminar em autopunição do tipo re-infecção e suicídio. O sujeito devolve ao seu eu o ódio ao objeto.

"Tanto o luto quanto a melancolia foram precedidos de uma escolha objetal, uma ligação objetal e uma perda do objeto. No entanto, no luto há uma retirada da libido do objeto perdido e um deslocamento da mesma para um novo. Na melancolia (...) [isso não é possível] (p.61). A libido não se liga a um novo objeto. Retorna ao seu eu sob a forma de auto-recriminação e culpa pelo objeto perdido. O paciente pode chegar ao suicídio, que aparece como uma busca de identificação com o objeto perdido.

Sugestões: não há.

Indicação bibliográfica:

Costa LPM, Mello Filho J de. Atendimento psicoterápico em um caso de aids. Inform. Psiq. 1988; 7(1): 20-5.

Costa LPM, Lima CQ, Mello Filho J de. Grupoterapia com pacientes HIV positivos (Aids). Inform. Psiq. 1989; 8(3): 97-103.

Cassorla RMS. Lidando com aids: uma experiência de supervisão de equipe multiprofissional. In: Cassorla RMS (coord.). Da morte: estudos brasileiros. Campinas: Papirus; 1991. p.231-41.

Oliveira Neto MX. O paciente homossexual HIV positivo (Aids) e a morte. J. Bras. Psiq. 1990; 39(5): 244-9.

\section{FICHA TÉCNICA - TEXTO 24}

Autor: Carlos A. Garrido Pereira

Instituição: Sociedade de Psicanálise do Rio de Janeiro

Local: Rio de Janeiro

Ano: 1994

Título: Unidade sem igualdade: caminho da "permissão".

Tipo de Produção: Artigo

Instituição Envolvida: Trabalho de reflexão teórica

Tema Principal: Psicoimunologia/psicossomática. Mente-corpo (aspectos genéticos e psíquicos da doença).

Objeto do Texto: Refletir sobre as similaridades existentes entre os anticorpos, os genes e a mente, tendo como base de discussão a doença e o adoecer. Trata dos enigmas e modelos de funcionamento dos sistemas psíquico e imunológico.

Conceitos abordados: relações objetais, pulsão de morte, mecanismos de defesa. 
Objetivo do Texto: Esclarecer alguns conceitos: unidade - entidade psicobiológica ora dual ora una e sua semelhança com a unidade formada pela dupla analista/paciente. Parte do pressuposto que existe uma competição entre Eros (sistema imunológico) e Thanatos (célula degenerada) no caso do câncer, diferenciando do caso da aids, em que a doença só se manifesta quando é permitido o material do retrovírus ser incorporado ao patrimônio genético do portador, substituindo-o (característica do retrovírus).

\section{Linha Teórica: Freudiana/Kleiniana}

Conclusões: PEREIRA reconhece que correu o risco de apresentar um trabalho “... não conclusivo e complexo, quer em Psicanálise quer em Imunologia" (p.59), mas que apresenta um caminho que é o de se pensar sobre o enigma do ser humano: a vida e a morte. Considera que os estudiosos desta área têm muito pela frente, e que a psicoimunologia é um novo desafio que se apresenta à prática psicanalítica. O desafio é o entendimento do "mistério da vida”. “... a Unidade com Igualdade é a busca, embora nunca possível, como meta a ser alcançada, diante das surpresas e azares da vida. (...) Essa meta seria a busca de um local e de um estado interno poucas vezes visitado pelo homem, a não ser de forma fugaz. Como diria Hélio Pellegrino: A condição humana jamais será curada" (p.59).

PEREIRA afirma: “... temos mais problemas que soluções. O caminho continua o mesmo, ou seja, entender o que se passa ou se passou em várias vias: pela via do psicanalista e pela via do paciente; pela via do SOMA e pela via Mental. Tentamos introduzir uma outra via: a doença em si, com suas particularidades e que a tornam um instrumento de Thanatos único. (...) precisaríamos nos ater a um fato de suma importância: há uma distância entre a interpretação e a linguagem do corpo, espaço ainda não atingido pelo psíquico ou pelas defesas corporais. Talvez aqui esteja a evidência das tendências thanáticas da pulsão de morte" (p.59-60).

Sugestões: não há.

Indicação Bibliográfica: Não foi encontrada referência de interesse para o presente estudo.

\section{FICHA TÉCNICA - TEXTO 25}

Autor: Célia Klouri

Instituição: Não explicitada

Local: São Paulo

Ano 1995

Título: Paciente terminal: análise possível-impossível, terminável-interminável?

Fonte: Boletim de Novidades Pulsional 1995; 80: 53-4.

Instituição Envolvida: Consultório Particular

Tema Principal: Questões relacionadas às possibilidades de se analisar pacientes com HIV/AIDS, dado que tem sua morte anunciada. Questiona-se: o papel do analista muda em função da saúde ou doença orgânica do paciente? 
Objeto do Texto: Possibilidade ou não de se analisar pacientes terminais. Escuta do Inconsciente. Subjetividade. Discriminação dos pacientes pelos analistas.

Conceitos abordados: narcisismo, inconsciente, transferência.

Objetivo: Questionar e refletir sobre os critérios de análise dos pacientes HIV positivos e doentes de aids, sobre a abordagem da dimensão psíquica e da subjetividade e do inconsciente desses pacientes.

Linha Teórica: Lacaniana

Conclusões:

a) Há uma recusa dos psicanalistas em escutar as pessoas que se encontram gravemente doentes, angustiadas e aterrorizadas diante da morte de um lado e, de outro, os que se propõe a ajudar e obturar a falta, a ferida narcísica (os "profissionais de ajuda" — o tom é irônico por parte dos que fazem).

b) O indivíduo com uma doença orgânica apresenta necessidades biológicas, mas também, com o dom da fala faz uma demanda de amor, formulada e dirigida ao outro. No espaço entre a necessidade e a demanda pode surgir o desejo, de onde advém o sujeito do inconsciente. Essa demanda é o que é analisável e possibilita o campo da transferência e o desenrolar do tratamento.

Sugestões: Segundo a autora, a tarefa do analista consiste “... em dar voz a esses indivíduos, criando um espaço para que seu sofrimento seja nomeado e simbolizado. Um espaço que transcenda o gemido de dor e faça ascender a palavra, o sujeito, rompendo o silêncio, a mentira e o isolamento a que estão confinados" (p.54).

Indicação Bibliográfica: Não foi encontrada referência de interesse para o presente estudo.

\section{FICHA TÉCNICA - TEXTO 26}

Autor: Eliana Costa Dias; Maria Elisa Pessoa Labaki; Celina Daspett e Katarina Queirós Farias Instituição: Hospital das Clínicas da Faculdade de Medicina da USP

Local: São Paulo

Ano: 1996

Título: Avaliação das vicissitudes do atendimento de pacientes $\mathrm{HIV}^{+}$em psicoterapia de grupo

Fonte: Revista Insight. 1996; AnoVI: 63: 16-20.

Tipo de Produção: Artigo

Instituição Envolvida: Ambulatório de Moléstias Infecto-contagiosas do Hospital das Clínicas da FMUSP

Tema Principal: Psicoterapia de grupo com pacientes $\mathrm{HIV}^{+}$

Sub-temas: Enquadre. Referencial teórico psicanalítico e grupos operativos. Ampliação ou transposição das experiências individuais para a realidade grupal (que reproduz o âmbito social)

Objeto: Psicoterapia de grupo com pacientes $\mathrm{HIV}^{+}$.

Conceitos abordados: circulação fantasmática grupal, tarefa, identidade, narcisismo, castração, eu 
ideal e ideal de eu, alteridade, luto e melancolia, processo terapêutico.

Objetivo: Analisar os benefícios oferecidos pela psicoterapia de grupo, segundo critérios específicos de sua formação e verificar sua efetividade.

Linha Teórica: Freudiana, Pichoniana, Blegeriana

Conclusões: "A psicoterapia de grupo propicia aos pacientes uma experiência de identificação, exposição e tentativa de elaboração de seus pensamentos, afetos e fantasias em relação aos conflitos vivenciados" (p.17). "O fato de ter começo, amadurecimento e fim, mostrou-se operativo para os sujeitos, fazendo emergir da imobilidade vivida no interior da realidade psicossocial da aids um movimento transformador e criador de novos processos identificatórios e novas representações. (...) possibilitou a recuperação de um sentido de pertinência ao grupo social” (p.20).

Sugestões: não há

Indicação Bibliográfica: Não foi encontrada referência de interesse para o presente estudo.

\section{FICHA TÉCNICA - TEXTO 27}

Autor: Maria Elisa Pessoa Labaki

Instituição: Instituto Sedes Sapientiae

Local: São Paulo

Ano: 1996

Título: Aids: uma clínica da indagação

Tipo de Produção: artigo

Fonte: Cadernos de Subjetividade. 1996; 4(1/2): 153-61.

Instituição Envolvida: Consultório privado

Tema Principal: Questionamentos a partir da aids como doença de final de século:

a) Surge como doença do outro.

b) Possui modo de transmissão por contato humano (relações intersubjetivas).

c) É uma doença de natureza política, cultural, ética, educativa e coletiva.

d) Demanda uma clínica psicanalítica especial?

Objeto do Texto: Indagação sobre a clínica psicanalítica da aids.

Conceitos abordados: narcisismo primário, desejo, identidade, estranho (o outro), pulsão sexual, pulsão de autoconservação, angústia de castração.

Objetivo de Texto: Refletir sobre a aids enquanto doença de final de século e o que ela mobiliza na sociedade e na clínica psicanalítica, considerando como ponto primordial a sexualidade humana.

Linha Teórica: Freudiana

Conclusões: A aids muda a cena da erradicação das doenças decorrente da modernização das técnicas de tratamento e prevenção.

Não há uma clínica especial para portadores do HIV ou aids, a clínica psicanalítica é uma clínica do sofrimento psíquico. “... a condição de portar o HIV, por si só, não sustenta um pedido de 
análise. (...) Não há a priori uma regra de indicação de análise para toda pessoa portadora do vírus. O que supõe um atendimento em psicanálise é o grau de sofrimento conjugado ao desejo de falar e ser escutado, refletir e ser acolhido, trocar a dor por palavra, para poder saber mais sobre aquilo que julga ser o motivo de seu sofrimento e acredita não conhecer" (p.158).

“A vertente que se coloca é a da produção de singularidades não catalogáveis, nem predizíveis porque o sujeito do desejo não é homogêneo ou finito: é dividido, contraditório e vai se constituindo a partir do seu acontecer" (158).

"Diferente de outras doenças incuráveis, em que o médico se permite o direito de excluir a morte do panorama futuro de vida de seu paciente, o caráter de transmissibilidade da aids obriga-o a anunciá-la a quem a porta. (...) a qualidade de portador sadio (...) incrementa a vivência da morte como fantasma, pois no real do corpo suas marcas ficarão por longo tempo desconhecidas. Impossível de ser prevista, a morte anunciada recupera para o portador a sua dimensão humana" (p.159) (destaque da autora).

A aids provoca perdas como a de um projeto de vida, de laços afetivos, do anonimato, que podem produzir novos sentidos à vida do portador do HIV.

Frente à pergunta "porque comigo?", a autora conjetura como sendo a expressão lingüística de uma posição de surpresa pela constatação de não ser alguém especialmente dotado. É como se fosse um ataque ao narcisismo primário, através do qual o sujeito se sentia especial.

"A aids inaugura um sentido de responsabilidade para com a própria saúde e a do outro, fazendo do encontro sexual um ato não mais de paixão cega, mas de parceria. Novos sentidos de vida revelam-se (...). A aids recupera a equivalência simbólica, o valor do desejo, a tolerância às diferenças e talvez o vínculo com a vida, no que ela tem de mais sagrado e que a nós pouco pertence" (p.160).

Sugestões: As reflexões finais, colocadas no item "conclusões" são, por si só, sugestões para se pensar a respeito da aids feitas pela autora, baseada em sua experiência clínica com soropositivos.

Indicação Bibliográfica: Não foi encontrada referência de interesse para o presente estudo.

\section{FICHA TÉCNICA - TEXTO 28}

Autor: Arakcy Martins Rodrigues

Instituição: Universidade de São Paulo - Instituto de Psicologia

Local: São Paulo

Ano: 1996

Título: O hiato entre conhecimento sobre as vias de transmissão e as práticas de prevenção da aids entre estudantes da USP: a atuação das ideologias coletivas de defesa.

Tipo de Produção: Artigo

Fonte: Revista Psicologia USP. 1996; 7(1/2):51-71

Tema Principal: Fatores inconscientes que regem a ação humana (dificuldade de mudança de 
comportamento decorrente de campanhas de prevenção da aids)

Sub-temas: Ideologias coletivas de defesa. Enfoque psicanalítico de DEJOURS (organização do trabalho). Conceitos de BOURDIEU (habitus). Enfoque teórico de BOLTANSKI que se aproxima da problemática envolvida no caso da aids

Objeto do Texto: $\mathrm{O}$ hiato entre conhecimentos e práticas preventivas em relação à aids entre estudantes (30) de graduação da USP. A atuação das ideologias coletivas de defesa.

OBS.: Trata-se de um ensaio sobre o tema que será objeto da pesquisa a ser realizada. A autora faz as considerações teóricas sobre as quais se baseou ao elaborar a proposta de pesquisa. Assim o objeto do texto se diferencia do objetivo da pesquisa.

Conceitos abordados: negação e dissociação.

Objetivo do Texto: Aprofundar a compreensão sobre os achados de pesquisas - envolvendo as mudanças de comportamento decorrentes de ações educativas de prevenção e uni-los num traço contínuo. Trabalhar com a hipótese de uma "ideologia de defesa" compartilhada e construída socialmente, inconsciente, como resposta a uma realidade intolerável (destaque da autora).

Linha Teórica: Cita alguns trabalhos de FREUD e utiliza-se do desenvolvimento da psicanálise aplicada ao trabalho (DEJOURS), de um referencial sociológico (BOURDIEU) e epidemiológico.

Conclusões: Em muitos trabalhos na área de prevenção à aids menciona-se os "fatores emocionais", sem que se faça sobre eles um aprofundamento em termos de melhorar explicitação ou explicação de sua influência (destaque da autora). Nesse sentido ela acredita que há a necessidade de estudos das mediações intrapsíquicas, que não chegam ao conhecimento do pesquisador. Explica a quase inexistência desses estudos pelos fatores:

- a baixa presença de psicólogos, psicólogos sociais, psiquiatras e psicanalistas em atividades de pesquisa mais ampla, faltando, inclusive, instrumentos adequados para este tipo de análise;

- a crença de que fatores subjetivos e irracionais não podem ser capturados através de raciocínio objetivo e lógico dos pesquisadores e por isso só há a menção e não o estudo desses fatores;

- a certeza sobre o caráter individual dos processos psíquicos e a sua identificação com "diferenças individuais", sob a influência, portanto, de determinações singulares (destaque da autora).

RODRIGUES considera que muitos processos psicológicos não são individuais e que, muitas vezes são criados e compartilhados coletivamente, como é o caso dos sistemas coletivos de defesa e da ideologia defensiva de DEJOURS (1987) e dos sistemas sociais de defesa de MENZIES (1970). Pode-se acrescentar o estudo de FREUD "Psicologia das Massas e Análise do Eu" (1930), como sendo um trabalho que também vai na mesma direção. "Entre o que chamamos de mediações intrapsíquicas se incluem os mecanismos pelos quais as próprias determinações sócio-culturais se efetivam. (...) existe hoje, igualmente, o discurso do direito à diferença, a veiculação da Psicanálise no que se refere ao desejo e suas variadas formas de satisfação, a militância de grupos que reivindicam cidadania de primeira classe em todos os segmentos sociais que se distanciam da norma. (...) Na nossa opinião, dois fatores principais [podem explicar a defasagem entre o 
conhecimento e as práticas]: a) o tipo de sexualidade, do ponto de vista da busca do prazer e não da repressão (Ideologia do erotismo, PARKER 1994, p.144 e segs citado por ela) e b) mecanismos de defesa individuais e coletivos, cujo caráter inconsciente estará inscrito no próprio conceito utilizado. É desse segundo item que nos ocuparemos nesta proposta" (p.55-6) (destaque da autora). Sugestões: A própria pesquisa que será desnvolvida pela autora. Levar em conta as considerações feitas para ocupar o lugar lacunar apontado por ela.

Indicação Bibliográfica: Não foi encontrada referência de interesse para o presente estudo.

\section{FICHA TÉCNICA - TEXTO 29}

Autor: Miriam Abduch

Instituição: Universidade de São Paulo - Instituto de Psicologia - Departamento de Psicologia Clínica

Local: São Paulo

Ano: 1997

Fonte: -

Título: Aids: Discursos de vida diante da morte - Estudo de mulheres portadoras do HIV, sintomáticas e assintomáticas.

Tipo de Produção: Tese de Doutorado

Instituição Envolvida: não é explicitada

Tema Principal: Correlação positiva entre psiquismo integrado e fragilidade diante do vírus da aids Sub-temas: Capacidade de usar o potencial criativo para transformar a realidade. Teste de Rorschach temático (contar estórias) como instrumento para analisar os temas acima.

Objeto do Texto: Estudo de mulheres portadoras do HIV e/ou aids através do seu discurso nas estórias contadas a partir do teste de Rorschach temático e entrevistas clínicas.

Conceitos abordados: potencial criativo, simbolização, ambiente (realidade).

Objetivo do Texto: Verificar a relação entre integração psíquica e fragilidade diante do vírus da aids, tanto em mulheres soropositivas, quanto naquelas portadoras da doença.

Linha Teórica: Winnicottiana

Conclusões: A autora constatou que as mulheres portadoras do vírus apresentam-se, do ponto de vista psíquico, menos integradas que aquelas que já desenvolveram a doença. Defende a hipótese de que a falta de integração destes grupos de mulheres ocorre devido a falhas precoces no seu desenvolvimento maturacional, falhas de adaptação mãe-bebê que, provavelmente se mantiveram no decorrer de suas vidas. Essa falta de integração resulta num precário contato com a realidade externa. No caso da aids ela pode se manifestar através da negação da doença. "Em função das características precípuas da doença, a aids tende a aparecer mais tardiamente nestas mulheres menos conectadas com a sua realidade de soropositivas; isso porque o vírus HIV atua no sistema imunológico cuja depressão está intimamente associada à depressão emocional” (p.150) (destaque 
da autora). A autora corrobora sua afirmação com uma citação de VASCONCELOS (1992), texto analisado no presente estudo, mas excluído por não estar contemplado no seu critério de inclusão. Nesse trabalho, o autor desenvolve a idéia da aids como uma doença "psicoimunológica". O texto trata da questão de haver um estado de alerta no organismo do soropositivo. "Mulheres mais integradas psiquicamente tendem a receber simbolicamente o vírus, já que este é para elas um dado de realidade e deve ser simbolizado e não negado. (...) as mulheres que mais viveram foram as que desenvolveram mais rápido a doença. (...) A morte aproximou-se com mais veemência das mulheres mais receptivas à vida. (...) [mas] encontram-se em momento de criatividade" (p.151-2) (destaques da autora). E isso ocorreu com serenidade, garantindo sua existência enquanto Ser.

Sugestões: ABDUCH, baseada na teoria de WINNICOTT, e em sua citação de que “... a integração de uma personalidade (...) vem e volta e (...) pode ser perdida por um acaso infeliz provocado pelo ambiente" (WINNICOTT, 1993: 356 citado por ABDUCH, 1997 p.152), sugere que nas mulheres com aids, a doença e o sentimento de morte eminente podem ter sido um fator integrador. Aspira que sua pesquisa possa ampliar o campo de estudo deste tema sugerindo novos trabalhos: correlação entre o simbolismo das pranchas e as histórias do Rorschach Temático, estudo prospectivo das mulheres sem aids, ou uma pesquisa específica da prancha VI (que simboliza a sexualidade), que possam contribuir para o conhecimento desta doença.

Indicação Bibliográfica: Não foi encontrada referência de interesse para o presente estudo.

\section{FICHA TÉCNICA - TEXTO 30}

Autor: Celi Denise Cavallari

Instituição: Pontifícia Universidade Católica de São Paulo - Programa de Estudos Pós Graduados em Psicologia Clínica

Local: São Paulo

Ano: 1997

Título: O impacto da comunicação do diagnóstico HIV Positivo: a ruptura de campo diante da soropositividade

Tipo de Produção: Dissertação de Mestrado

Fonte: -

Instituição Envolvida: Ambulatório de Imunodeficiências Secundárias do Serviço de Alergia e Imunologia do Hospital das Clínicas da Faculdade de Medicina de São Paulo

Tema Principal: Comunicação do resultado - forma como é dado o resultado.

Sub-temas: Trauma e angústia resultante da comunicação. Teoria dos campos de Fábio HERRMANN.

Objeto do Texto: Impacto provocado pela revelação do diagnóstico HIV positivo

Conceitos abordados: Teoria dos campos, organização psíquica, identidade, identidades sexuais.

Objetivo do Texto: Estudar o impacto provocado pela revelação do diagnóstico HIV positivo; qual 
a influência da proximidade do risco na reação do paciente ao resultado HIV positivo; como a ruptura de campo no momento do resultado interfere no campo constituído após o diagnóstico; como a forma de comunicar o diagnóstico interfere no psiquismo do sujeito e se a organização psíquica após o diagnóstico é uma questão de tempo.

Linha Teórica: Freudiana e o desenvolvimento da mesma feita por Fábio HERRMANN

Conclusões: Para as pessoas entrevistadas neste estudo, o momento do resultado HIV positivo foi decisivo, mudando suas vidas.

Sobre a consciência do risco, dentre os pacientes heterossexuais (homens e mulheres), não havia o sentimento de estarem em risco até haver um motivo para fazerem o exame. Alguns pacientes homossexuais que não se identificavam com a homossexualidade, não se viam em risco, enquanto que outros, vivenciaram a consciência da proximidade o risco como imponderável. "Os conflitos não elaborados relacionados à inclinação homoerótica revelaram-se impeditivos de medidas preventivas" (p.196). As pessoas com mais preconceito perante a aids vivenciaram maior desorganização frente ao resultado positivo, pois estas representações não estão associadas à sua identidade e realidade.

O período que antecede o resultado do exame foi vivido como angustiante, com fantasias persecutórias e associações referentes à sexualidade reprimida.

O momento do resultado foi considerado um acontecimento traumático na vida destes entrevistados e o conhecimento do diagnóstico “... provocou uma ruptura no campo organizador de seu aparato mental...” (p.196), revelando emoções e desvelando aspectos inusitados. O grau de desorganização psíquica decorrente dos resultados e a possibilidade de reorganização foram diferentes a partir da história de cada sujeito.

O sujeito, a partir do resultado positivo, faz uma nova interpretação sobre si mesmo, integrando fragmentos do campo anterior ao diagnóstico (chamado de ruptura pela autora).

O campo ocorre sempre em relação à forma como é dado o diagnóstico ao paciente, assim como sua ruptura.

"A relação com o paciente soropositivo é disruptiva por trazer à tona o contato com dimensões desconhecidas inconscientes" (p.198). O resultado redimensiona o passado e o futuro a partir das possibilidades de interpretação do sujeito no presente.

"Pacientes que no novo campo estabelecido após o diagnóstico não puderam elaborá-lo, evidenciaram desenvolvimento de patologias orgânicas e dificuldades em constituir novos projetos de vida" (p.198).

Existem fatores que intensificam a angústia relacionada ao diagnóstico e favorecem a revivescência da situação traumática da comunicação diagnóstica. São eles: diminuição da contagem de CD4, doenças oportunistas, adoecimento ou morte de amigos ou parceiros sexuais, etc.

Os pacientes apresentam alterações no horizonte temporal ao se referirem ao momento da comunicação do teste HIV, contradizendo-se quanto a datas e o tempo de diagnóstico, sintoma da 
desorganização psíquica vivida.

Há um impacto provocado pela comunicação do diagnóstico e é necessário alterar a forma de dar a notícia. No momento da comunicação, as falas e atitudes dos profissionais são fundamentais para dar suporte frente ao sentimento de desamparo desencadeado, para favorecer a elaboração do diagnóstico. A equipe deve compartilhar a responsabilidade desta tarefa para dar suporte aos pacientes.

Sugestões:

CAVALLARI dá várias sugestões para minimizar o impacto verificado nas suas conclusões que vão desde o tempo de espera que antecede o resultado até o durante e o depois. Em geral, sugere que se dê mais suporte ao paciente, permitindo-lhe um tempo para expor suas emoções, elaborar a notícia, incluir a sua história e minimizar seu sofrimento, e abrir a possibilidade de retomar ao serviço caso necessite de mais espaço. Segundo ela, isso auxilia o paciente no processo de elaboração da revelação diagnóstica, mas vai depender, também, da possibilidade do sujeito de narrar a própria história. Isto ajuda o profissional, para que não se sinta tão impotente. Sugere o compartilhamento pela equipe e o revezamento dos profissionais para fornecer o resultado.

Indicação Bibliográfica: Não foi encontrada referência de interesse para o presente estudo.

\section{FICHA TÉCNICA - TEXTO 31}

Autor: Peter Pál Pelbart (coord.) (1); Jean Claude Bernadet (2); Maria Rita Kehl (3) e Jurandir Freire Costa (4)

Instituição: (1) Pontifícia Universidade Católica de São Paulo; (2) Escola de Comunicações e Artes da Universidade de São Paulo; (3) Não explicitada no texto; (4) Instituto de Medicina Social da Universidade Estadual do Rio de Janeiro.

Local: São Paulo

Ano: 1996 (o evento), 1997 (a publicação)

Título: Colóquio sobre Aids

Tipo de Produção: Comunicação em Evento

Fonte: Cadernos de Subjetividade. 1997; 5(1): 183-204.

Instituição Envolvida: Núcleo de Estudos e Pesquisa da Subjetividade da PUC-SP e Instituto Sedes Sapientiae

Tema Principal: A doença, o doente (sua subjetividade), redes de solidariedade (contaminações positivas), a morte e a vida a ética e a política em torno da questão da aids.

Objeto do Texto:

Publicação das falas dos convidados do evento que foi promovido para arrecadar verbas para a manutenção do tratamento de uma pessoa doente de aids (chamada de Amigo) e pelos organizadores desejarem transformar uma situação de impotência numa ação coletiva de solidariedade, possibilitando espaços de troca. 
Objetivo do Texto:

Falar da doença e do doente, incluindo a sua subjetividade e a subjetividade do coletivo que está em seu entorno. Falar da morte e da vida “... que não é monopólio dos não-aidéticos” (p.184). Abordar a questão social em torno da aids e do imaginário construído.

Linha Teórica: Não se aplica neste texto, pois se trata de falas em um evento onde estão "condensadas" várias linhas teóricas.

Conclusões: Far-se-á um apontamento dos principais pontos assinalados em cada fala.

Jean Claude Bernadet

O autor faz uma reflexão sobre o seu livro "A doença: uma experiência", no qual constrói a imagem do doente baseada na própria vivência. Ressalta que o livro nem é ficção, nem é autobiografia, mas mescla das duas coisas. Em função disso, prefere classificá-lo como ficção autobiográfica. Explana sobre a forma como foi produzindo seu texto, respeitando e desrespeitando a cronologia dos acontecimentos, a vivência real e a fantasiada ou inventada, e a sua inclusão tanto como autor ou quanto como narrador. Nesse último aspecto, considera indiscerníveis, por vezes, essas duas figuras, havendo uma fluidez, uma fusão e uma confusão entre elas. Admite que o que busca “... é uma quebra entre determinados compartimentos e que se possa encontrar uma passagem fluente, pouco nítida e pouco definida entre um sujeito público, que no caso seria o narrador, e um sujeito privado, representado pela pessoa do autor. Ou entre o espaço privado, que seria a vivência e o espaço público que é o texto literário" (p.190). Conclui que, nessa dinâmica pode se fazer uso de uma máscara, uma imagem forjada para se tornar pública. Essa seria, segundo ele, uma terceira figura para além do autor e do narrador.

\section{Maria Rita Kehl}

A participação de Kehl é no sentido de expor sua opinião sobre o artigo que escreveu intitulado "A doença na literatura" motivada pela leitura dos livros: "A doença: uma experiência" de BERNADET e de "Moça, interrompida" de Suzanne KAYZEN. Comentando a colocação de BERNADET, KEHL destaca que, sendo ou não ambos os livros autobiográficos, trazendo ou não fatos ocorridos, não importa tanto, quanto o fato de serem verdadeiros, no sentido de conterem verdades humanas. No caso de KAYZEN, que fala no livro sobre sua psicose, KEHL assinala que a autora está preocupada “...muito menos com o $e u$, no sentido de sentir-se responsável ou culpada por ter adoecido...” (p.193). Percebe-se que ela está implicada no seu mal, na sua doença, na experiência pela qual passou. A razão de tudo o que lhe aconteceu é ela ter se aberto para várias dimensões da vida, sem ter tomado as precauções necessárias. Era uma adolescente na época. KEHL faz suas próprias associações a partir das reflexões sobre a leitura do livro. Considera que sempre existe uma implicação do sujeito em tudo o que ele faz. Sempre existe um risco em tudo

\footnotetext{
* O autor não é psicanalista. Participou do evento por ter escrito um livro sobre a sua experiência com a Aids.
} 
que se faz, o que não impede que se faça o que se deseja, seja tomar um avião, seja ter uma relação sexual sem preservativo, seja o que for. Ocorre que o sujeito acha que sempre está no controle da situação, uma certeza neurótica, segundo ela. Quando está dentro do avião, vive-se uma suspensão por não ter controle do que vai acontecer, assim como em outras situações semelhantes. KEHL sugere que se pode aceitar a situação de "completo desamparo", em que a vida não pertence ao sujeito e indaga: “... mas quando é que a vida nos pertence?" (p.195) Constata a necessidade de uma dose diária de negação para lidar com o cotidiano, para acreditar que tudo vai continuar no dia seguinte. Com a aids ocorre o mesmo. Comenta que isso está impresso no livro de BERNADET: "a sensação de que cada passo tem conseqüências, de que cada decisão tem uma gravidade e também uma leveza, uma vez que (num certo sentido) nada há a fazer" (p.195). Em um outro sentido, tudo pode ser decidido: vai ou não vai, toma ou não toma remédio, etc.

A autora lembra a colocação de FREUD, na qual o neurótico escolhe viver em uma fatia do real que não toca o que está recalcado; mantendo o recalque. A doença promove o contrário. O saber sobre a morte (negada) se revela. Destaca-se um sentido de que a vida pode ser interrompida e, a vitalidade e o impulso, desperdiçados. Associa ainda, o fato de que o medo de avião, muito comum a certas pessoas, o contágio podem remeter à dimensão da feminilidade, utilizando o termo no sentido de passividade (como FREUD o fazia). "O que existe não é horror ao avião, é um horror à posição feminina. E, no final das contas, o contágio e o estar doente não são outra coisa: já foram atravessados por algo que não dependeu de nós" (p.197). Reflete sobre a Psicanálise que está sendo utilizada no evento: não a do pertencimento da produção psíquica ao sujeito, mas a da identificação solidária, a da implicação com o que vem do outro, que tem a ver com cada um. Coloca a doença como algo que não é propriamente do doente, mas uma parte do real buscando uma linguagem, uma simbolização. A escrita sobre a experiência da doença é uma confirmação disso.

Com a aids isso ocorreu. As pessoas se mobilizaram para falar da vida em vez da morte. A doença cria um novo campo, um novo fenômeno social. Cria uma saída da posição feminina de passividade e de perplexidade para o sentido da linguagem e das palavras.

\section{Jurandir Freire Costa}

COSTA fala de sua pesquisa sobre a amizade como algo central nos relacionamentos modernos, com as sexualidades e suas conseqüências, dentre elas, o risco do contágio pelo vírus HIV.

Em sua pesquisa anterior com homens com inclinação homoerótica (analisada neste estudo no texto 7) verificou que o risco de contágio aumentava conforme a oportunidade de relacionamento afetivo se apresentava.

$\mathrm{Na}$ pesquisa atual com jovens heteroeroticamente inclinados, concluiu que “... não existe diferença entre as hierarquias sexuais presentes e a cultura preconceituosa de antes. Os jovens persistem desaprovando e condenando as práticas sexuais minoritárias, em nome de uma vaga normatividade natural, baseada no que é socialmente tido como desejável" (p.200) (destaque do autor). 
Constatou que existia uma certa facilidade para encontrar parceria sexual, mas não para parceria amorosa, fosse qual fosse a inclinação sexual do pesquisado, gerando frustração. $\mathrm{O}$ autor começou a voltar o seu olhar para o sentimento de amor como um fenômeno histórico, com uma genealogia possível de se reconstituir. “... é um modo de interação pessoal e um modelo ideal de realização subjetiva que foi progressivamente formado na civilização ocidental. (...) Com ROUSSEAU ligamos sexo, amor e conjugalidade, amálgama que até hoje, modela nosso imaginário, enquanto ideal de felicidade sentimental" (p.202).

Em psicanálise, amor se liga à sexualidade, cuja realização pessoal passa pela "ternura" (FERENCZI), “amor primário" (BALINT), "apego" (BOWLBY), “uso de objeto" (WINNICOTT), segundo COSTA, todos se equivalendo. (destaques do autor)

Propõe pensar na formação de outras redes de convívio e de socialidade em que possa emergir o amor-paixão como uma das formas de satisfação pessoal, mas não a única, dado que está cada vez mais rara essa forma de realização. Neste sentido é que se insere a Amizade. É um sentimento na fronteira entre o público e o privado, servindo tanto para elaborar identidades subjetivas, como projetos e ideais coletivos, podendo também suscitar grandes intensidades emocionais. Faz a ressalva de não estar tentando substituir o amor por amizade, mas sim, de viabilizar uma forma cultural atual de se obter felicidade, já que a anteriormente idealizada não é mais tão viável (a realização na relação a dois como única de relevante para a obtenção da felicidade).

COATA salienta a importância de "sentir-se real", "ter a experiência de ter contato com a vida", coisas que se pode exercitar sem ter que ficar submetido a ideais que, "...quanto menos têm condições culturais de se realizarem, mais tirânicos podem se tornar" (p.204) (destaques do autor).

Sugestões: Estão implícitas em cada fala.

Indicação bibliográfica: Não há referências neste texto.

\section{FICHA TÉCNICA - TEXTO 32}

Autor: Andrea Giovanetti(1) e Iolanda Évora(2)

Instituição: (1) Instituto Sedes Sapientiae e (2) Núcleo de Estudos e Prevenção da Aids (NEPAIDS-USP) e Núcleo de Estudos da Violência da USP

Local: São Paulo

Ano: 1997

Título: A aids como construção social

Tipo de Produção: Artigo

Fonte: Revista USP. 1997; 33 (Dossiê Aids): 127-35.

Instituição Envolvida: ONG não identificadas para preservar a identidade das pessoas entrevistadas Tema Principal: Sexualidade: homossexualidade/homoerotismo. Morte. Doença.

Sub-temas:

Construção social da aids. Identidade e realidade 
Objeto do Texto: Discutir as hipóteses das autoras (inquirição das subjetividades dos entrevistados em busca do individual similar) sobre o porquê da diminuição do eu destas pessoas entrevistadas por um vírus fatal que subverte suas existências de forma dolorosa.

Conceitos abordados: homoerotismo e identidade homossexual, séries complementares, transferência, resistência, identidade e realidade.

Objetivo do Texto: Encontrar possíveis regularidades psíquicas frente ao conhecimento da infecção pelo vírus da aids.

Refletir sobre as representações histórico-sociais que têm determinado o sentimento de perplexidade e culpa, em menor ou maior grau, dos infectados, moldando assim a identidade do "aidético".

Realizar uma escuta psicanalítica do material coletado nas entrevistas.

Linha teórica: Citam alguns psicanalistas brasileiros: Jurandir Freire COSTA, Joel BIRMAN e Fábio HERRMANN, além de utilizarem alguns conceitos freudianos.

Conclusões: Alguns comentários e reflexões das autoras sobre os temas: sexualidade, morte e doença serão considerados como conclusões:

“... de acordo com as séries complementares freudianas, o surgimento ou agravamento de um desequilíbrio emocional mais manifesto poderia ter sido ocasionado por outros eventos de igual perniciosidade na vida desses indivíduos, não somente pela aids" (p.128).

Com relação à sexualidade:

“... a primeira regularidade presente nas entrevistas realizadas vem do sofrimento maior que representa precisar esconder a condição de soropositivo para não ser obrigado a revelar a inclinação homoerótica socialmente desvalorizada (...) Perpassa também (...) a noção de que a moral sexual conservadora finalmente levou a melhor (...) suas práticas individuais (...) de uma hora para outra foram proibidas. (...) a pressão social vigente [os faz crer] (...) que tal proibição se inscreveu em seus próprios corpos. O soropositivo (...) é efetivamente a morte que ele mesmo escolheu" (p.132). As autoras citam um trecho sobre transgressão, impureza e inferioridade, de PAIVA (1992).

Com relação à morte:

$\mathrm{Na}$ contemporaneidade, morrer passou a ser inaceitável, pois com os avanços da medicina se aumenta a expectativa de vida. Assim, com a aids, “... essa que se tornou o nome mesmo do inominável [e o que a porta] enfrenta um angustiante paradoxo: (...) é considerado socialmente morto para muitos (...) e, quando finalmente se aproxima a experiência tão temida, espera-se que abra mão do direito de exprimir tal terror, pois tal tensão emocional é incompatível com a regularidade da vida quotidiana (sic) familiar ou hospitalar...” (p.132-3). O indivíduo pode ou se resignar ou ser acusado de falta de fibra e de luta.

Com relação à doença: 
Muitos vivenciam a culpa pela infecção e sua ligação com a promiscuidade e homoerotismo é resultante da construção social da doença que, segundo as autoras, é um processo que deriva da medicalização do dia-a-dia. Em nome de manter e reproduzir a vida, a sexualidade torna-se de interesse público e instrumento de controle social. “A aids, exacerbando a tensão entre os interesses da coletividade na esfera da sexualidade (ligados à reprodução e seu controle) e os interesses individuais (ligados ao prazer), revela, mais claramente, os limites, na área da sexualidade, de tal modelo de normalização médica do social" (PAIVA citado por GIOVANETTI e ÉVORA, p.133). Com relação ao cotidiano:

Existe uma falta de sustentação social para o relacionamento entre pessoas do mesmo sexo. Também “... as ficções sociais constituídas sobre a aids afetam até mesmo a possibilidade de tratamento da doença, na medida em que a seqüestram do lugar de doença grave, fatal, mas apenas doença, para um outro que recende a maldição. (...) as vítimas circulam entre mitos nocivos, pois propagadores de relações irracionais de objetos...” (p.133-4) (destaque das autoras). Algumas decisões dos portadores passam pelo crivo destes mitos, dentre os quais à equiparação da aids com a morte.

GIOVANETTI e ÉVORA iniciaram o trabalho buscando uma peculiaridade psíquica que, através do referencial psicanalítico, dirigia-se para os modos de produção de sentidos gerados pelo desejo inconsciente, apontado para o estrato individual. Passaram a mirar o estrato social com o qual se interage constantemente no cotidiano, onde são experimentadas as ficções produtoras dos sentidos coletivos. Utilizaram as categorias estruturantes: sexualidade, morte e doença que são as experiências evocadas pela aids. Evidenciaram em seu papel de interlocutoras que elas representavam o social e era com este lugar que a transferência dos entrevistados operava, razão pela qual deve-se levar em conta as suas resistências. Ressalta-se, também, o sofrimento destas pessoas: com sua condição de clandestinidade diante da inclinação homoerótica e da condição clínica associada à aids, mesmo que assintomáticas.

Sugestões: As autoras, com seu artigo, aspiram desvelar algumas das regras de constituição do universo da aids, ao exercitar “... atribuir feições à obscura zona de fronteira entre identidade e realidade. Partindo da primeira, aportamos na segunda para lançar luz na anterior” (p.135). Consideram seu projeto uma epistemologia da solidariedade

Indicação Bibliográfica:

Costa JF. A inocência e o vício: estudos sobre o homoerotismo. Rio de Janeiro: Relume-Dumará; 1992.

\section{FICHA TÉCNICA - TEXTO 33}

Autor: Mauro Pergaminik Meiches

\footnotetext{
* Colocam um adendo a respeito do termo que caiu em desuso por ser politicamente incorreto, mas que
} 
Instituição: Pontifícia Universidade Católica de São Paulo - Programa de Estudos Pós-Graduados em Psicologia Clínica

Local: São Paulo

Ano: 1997

Título: Uma metáfora possível da morte?

Tipo de Produção: Artigo

Fonte: Revista USP. 1997; 33 (Dossiê Aids): 117-24.

Instituição Envolvida: Trabalho teórico

Tema Principal: Psicanálise e Arte. Relação da arte com a aids.

Objeto do Texto: Pensar na arte e suas conexões com outros campos do saber e com o universo da aids. Relacionar a arte (fotografias de Robert Mapplethorpe) com a sua morte.

Conceitos abordados: sublimação, real, repressão, metáfora.

Objetivo: Estabelecer a conexão entre arte e morte anunciada, entre sexualidade e linguagem, entre arte e aids. Para isso, utilizará os auto-retratos de Robert Mapplethorpe, fotógrafo americano, que morreu de aids em 1989.

Linha Teórica: Freudiana e lacaniana

Conclusões:

Sobre a obra:

“... ela tangencia o continente reprimido de todos, mesmo que nosso querer mais pessoal não esteja fotografado naquilo que está diante de nós" (p.121).

"A clareza de seus trabalhos, a atitude de absoluta confiança que inspira em seus modelos (...) revertem para uma imagem fascinante. (...) ele restaura também a agudeza do olhar, aquela que perdemos por excesso de civilização" (p.122-3).

O autor está se referindo ao quanto de impulsos epistemofílicos têm-se no início das pesquisas sexuais infantis e o quanto eles foram reprimidos pela civilização. Considera que o artista foi infectado por outro vírus antes mesmo do vírus da aids. $\mathrm{O}$ vírus da busca do autoconhecimento e do que vai fazer com o que é. "Através do artista, centro nevrálgico de interrogações, passa em desfile a humanidade inteira" (p.123).

MEICHES passa a comentar cada obra do artista, os seus auto-retratos. A presença da maquiagem denota um artifício, um código transgredido, uma ousadia. Parece reparar uma falta, um erro, um desejo que pode ter causado algum dano a alguém. Ela restaura um estado de coisas anterior à falta cometida, engana e convence senão quem a vê, pelo menos quem a usa.

"A androginia poderia ser o ponto inaugural onde começou a diferenciação entre os gêneros; voltar a ela seria retornar assintomaticamente a um ponto jamais inatingível" (p.124).

Ao longo das obras vai se percebendo a marca da aids "A morte perpassando o gênero, e junto com

continua sendo usado pela população em geral. 
ele, o sexo, é sempre assunto que se sobrepõe a qualquer outro" (124).

"A descorporificação é a morte em retrato. Ela difere da galeria de imortais que Mapplethorpe realizou, todas elas [as fotos] olimpicamente corpóreas; com esse movimento, metaforiza em imagem aquilo que jamais alguém conseguiu capturar" (124).

Na opinião de MEICHES, a seqüência das fotos não era intencional. As obras respondiam a uma indagação insistente “... que nunca cansamos de fazer a nós mesmos. (...) a leitura que ressignifica este caminho já encerrado pode se valer deles [dos auto-retratos] para constituir o caminho metafórico: ele era obrigatório, dele não havia como escapar. A infecção pela linguagem é, em vida, sempre mais poderosa. (...) A forma agonística não desaparece no último auto-retrato. A luta pela vida deixa sua marca na foto da morte. A linguagem, ainda, se impõe ao Real" (p.124).

Sugestões: não há

Indicação Bibliográfica: Não foi encontrada referência de interesse para o presente estudo.

\section{FICHA TÉCNICA - TEXTO 34}

Autor: Ana Cleide Guedes Moreira

Instituição: não identificada

Local: São Paulo

Ano: 1997

Título: Melancolia e aids: da urgência da escuta do sintoma*

Tipo de Produção: Artigo

Fonte: Boletim de Novidades Pulsional. 1997; 93: 23-36.

Instituição Envolvida: Consultório privado

Tema Principal: Melancolia e aids.

Sub-temas: Sexualidade. Fatores desencadeantes do déficit imunitário e da vulnerabilidade. Desejo de viver e desejo de morrer.

Objeto do Texto: Melancolia e aids. A urgência de escuta do sintoma.

Conceitos abordados: melancolia, mania, pulsão de morte, sintoma, desamparo.

Objetivo do Texto: Apontar, mediante um certo imperativo ético, os perigos que se somam quando vida e morte estão em jogo, especialmente quando a melancolia se associa à aids. Abordar algo de ordem terapêutica, no sentido de uma operação de buscar a eficácia contra o sofrimento e a morte. Apresentar a investigação que vem desenvolvendo em psicopatologia psicanalítica. Dar reconhecimento à SBPC. (A intenção do texto era a divulgação na reunião anual dessa sociedade).

Linha Teórica: Freudiana cita também LAPLANCHE e MANNONI

Conclusões: "Na maioria das vezes a associação melancolia/aids procura dar conta de situações onde a melancolia decorre da constatação da presença de HIV/AIDS. Mas será preciso seguir o

\footnotetext{
* Trabalho apresentado parcialmente na 48a Reunião Anual da SBPC, PUC-SP, 1996.
} 
outro rumo possível, supondo que a melancolia mesma, talvez sob a forma de mania, tenha conduzido já o sujeito à busca ativa, parcialmente inconsciente, da infecção pelo vírus HIV. Teríamos ai ocasião de refletir sobre as razões que levariam alguém a investir num objeto mortífero" (p.35).

Há urgência na escuta da associação melancolia/aids. "É preciso continuar a escutar atentamente (...) as produções imaginárias que o avanço da epidemia vai produzindo, para que possamos identificar nelas a manifestação da pulsão de morte, que nos habita a nós humanos, e que, no cumprimento de sua tarefa, destina-nos a ir ao encontro do inorgânico" (p.35-6).

Sugestões: “... é preciso oferecer uma escuta à associação melancolia/aids porque parece evidente que há uma nova figura que está criando e que produz efeitos mortíferos acentuados...” (p.33) para que as pessoas não se vejam excluídas.

\section{Indicação Bibliográfica:}

Birman J. A sexualidade entre o mal e as maledicências. In: Loyola MA. (org.) Aids e sexualidades. Rio de Janeiro: Relume-Dumará/UERJ, 1994. p.109-15.

Klouri C. Paciente terminal: análise possível-impossível, terminável-interminável? Boletim de Novidades Pulsional 1995; 80: 53-4.

Seffner F. $O$ jeito de levar a vida, trajetórias de soropositivos enfrentando a morte anunciada. UFRGS, Porto Alegre, 1995 (mimeo).

\section{FICHA TÉCNICA - TEXTO 35}

Autor: Leopoldo Nosek

Instituição: Sociedade Brasileira de Psicanálise de São Paulo

Local: São Paulo

Ano: 1997

Título: Psicanálise e arte: Leonilson - Uma reflexão

Tipo de Produção: Artigo

Fonte: IDE - Revista da Sociedade de Psicanálise de São Paulo. 1997; 93: 23-36.

Instituição Envolvida: Trabalho reflexivo sobre as obras do artista

Tema Principal: Psicanálise e arte

Sub-temas: Associação de obras de arte de José Leonilson, que morreu de aids em 1993, com conceitos psicanalíticos (BION). Organização consciente-inconsciente, interior-exterior, masculino-feminino. Sonho e representação.

Objeto do Texto: Reflexão sobre a análise das obras do artista Leonilson.

Conceitos abordados: elementos alfa e beta, representação, objeto.

Objetivo do Texto: Propor um outro olhar sobre as obras que ajude a realizar alguns conceitos de BION. Refletir, a partir do trabalho do artista, sobre o próprio conceito e prática analítica, sem a pretensão de realizar uma análise psicanalítica da obra de Leonilson. 


\section{Linha Teórica: Bioniana}

Conclusões: A obra de Leonilson serve como modelo para o psicanalítico. "São exercícios para a permanente perda e recuperação do que é nosso objeto e nossa prática" (p.60).

Sugestões: "Não devemos (...) apenas interpretar significados, mas possibilitar a passagem para a representação (...) [do que o paciente traz]. Esta representação pode ser sonora, visual, poética e até total. A palavra tem o aspecto sonoro, traz associações visuais e também algo do total” (p.60).

Indicação Bibliográfica: Não foi encontrada referência de interesse para o presente estudo.

\section{FICHA TÉCNICA - TEXTO 36}

Autor: Wolff Rothstein

Instituição: Não explicitada

Local: São Paulo

Ano: 1997

Título: Aids: o mal... está na civilização?

Tipo de Produção: Artigo*

Fonte: Ferraz FC, Volich RM (org.). Psicossomática: psicossomática psicanalítica. São Paulo: Casa do Psicólogo; 1997. p.209-31.

Instituição Envolvida: Trata-se de uma reflexão teórica

Tema Principal: A relação da aids com a civilização.

Sub-temas:

a) A doença como decorrente de inadequações de vida do indivíduo e as funções mentais como imunológicas (sendo defesas do homem contra doenças)

b) Ideal pós-moderno de "cura pela tecnologia"

c) Inclinação para a agressão

d) Sentimento de culpa (mal-estar)

Objeto do Texto: Associação da questão da aids com o texto de Sigmund FREUD "O mal-estar na civilização" publicado em 1930.

Conceitos abordados: Sublimação, sentimento de culpa.

Objetivo do Texto: Estabelecer uma analogia da epidemia da aids com os principais temas abordados do texto de FREUD. “... analisar como um indivíduo se comporta em relação à vida e seus atributos favoráveis ou desfavoráveis ao alcance da felicidade, as maneiras peculiares como ele pode driblar as dificuldades que se lhe apresentam (e que dependem fundamentalmente de suas características psíquicas peculiares) e, paralelamente, em que o fato de viver em comunidade e tentar construir uma civilização que o sustente e o direcione paradoxalmente dificulta a busca dessa felicidade" (p.226). 


\section{Linha Teórica: Freudiana}

Conclusões: O autor, ao traçar o paralelo com o texto de FREUD, constata sua atualidade, apesar de ter sido escrito décadas atrás. Considera que isso só foi possível porque o ser humano é dotado de paradoxo, e a acoplagem da questão da aids às idéias desenvolvidas deriva do caráter da pandemia só existir porque os seres humanos existem e se relacionam intimamente. Possuem instintos básicos que são satisfeitos através da busca imediata do prazer por cada um e pela coletividade. De acordo com a disposição dos indivíduos nas grandes cidades, em conglomerados, vivendo o drama da subsistência permeada pelas diferenças sociais, entende-se como a doença surgiu e se expandiu; inicialmente em alguns grupos “... que incomodavam, que expunham com certo heroísmo, uma espécie de natureza mais crua de desejos incontroláveis que sofriam, naturalmente, recorrentes tentativas de coibição, por todos os que, hipocritamente, fingiam ser imunes a eles. Mas hoje, (...) temos uma doença infecciosa disseminada pelos cinco continentes e, portanto, globalizada" (p.227).

ROTHSTEIN reflete sobre os comportamentos individuais - a favor ou contra a propagação do vírus - serem conseqüentes da relação dos mesmos com a civilização, considerando a doença não só do ponto de vista orgânico, mas também do imaginário individual e coletivo no qual ela se inscreve. Ela questiona valores, conceitos e pré-conceitos e não tem cura tecnológica até o momento. Resta o cuidado e a "continência" que envolvem o respeito pelas escolhas dos indivíduos de desistência, aceitação e/ou medo inerentes à proximidade da morte. Segundo o autor, “... é tão insuportável uma dor que se sabe inextinguível...” (p.228).

Quanto às formas de prevenção pelo sexo e pelo uso de drogas, o autor recorre mais uma vez a FREUD para explicar que os instintos que influenciam o humano e para os quais ele busca o prazer, são poderosos e agem diretamente sobre essas formas de infecção/prevenção. Compara a satisfação obtida indicando que um instinto não domado pelo ego, ao ser satisfeito, produz um sentimento de felicidade muito maior do que um outro que já foi domado. Conclui que este aspecto relaciona-se diretamente com a questão do uso do preservativo e o não compartilhamento de agulhas e seringas. Como controlar o impulso? Como promover a prevenção, se para isso é necessária a imposição de mais regras ao indivíduo, além das que a civilização já lhe impõe? Percebe-se que a satisfação dos desejos fica ameaçada frente às mudanças que se tem que operar para a prevenção; porém, pode-se pensar em ganhos com essas mudanças, no sentido do indivíduo tomar para si a responsabilidade pelos seus atos e se desenvolver, psiquicamente, com essa atitude. Pois, segundo ROTHSTEIN: "Temos desejos a satisfazer, temos que nos cuidar para realizá-los e somos parte de uma civilização que nos açoita a todo o momento, desprezando o que nos diz respeito, enquanto indivíduos, em prol de sua manutenção. Não é pouco.” (p.230).

Sugestões: Em decorrência de suas conclusões, o autor sugere que o caminho seja percorrido para

\footnotetext{
* O trabalho é decorrente da participação do autor no I Simpósio de Psicanálise e Psicossomática (local não
} 
cuidar dessas questões. Todos estão implicados nesta realidade, pois a aids faz parte da vida, seja qual for a condição sorológica de cada indivíduo. Deve-se tomar cuidado para que ela não seja mais um instrumento de repressão dentre os que já existem, mas uma possibilidade de expor os conflitos e paradoxos da civilização para, então, poder trabalhá-los. Criar “... uma ética baseada em saúde, em cuidado, mas respeitando sempre a opção de cada um, mesmo que esta não seja, de um ponto de vista técnico ou filosófico, positiva ou construtiva" (p.230) (destaque do autor).

Indicação bibliográfica: Não foi encontrada referência de interesse para o presente estudo.

\section{FICHA TÉCNICA - TEXTO 37}

Autor: Renate Meyer Sanches

Instituição: Não explicitada

Local: São Paulo

Ano: 1997

Título: Escolhi a vida - desafios da aids mental

Tipo de Produção: Livro

Fonte: Sanches RM. Escolhi a vida - desafios da aids mental. São Paulo: Olho d’Água, 1997.

Instituição Envolvida:Centro de Ajuda a Portadores e doentes de aids não identificado.

Tema Principal: Aids social. Aids mental.

Sub-temas: Depoimentos de soropositivos/Experiência de vida. Relação médico-paciente.

Objeto do Texto:

Analisar psicanaliticamente o processo pelo qual os portadores do vírus HIV passaram desde o conhecimento do diagnóstico e como enfrentaram a nova condição e a inseriram na própria história, dando-lhe um novo significado. O livro mostra a trajetória dessas pessoas para a superação.

Conceitos abordados: pulsão de morte, pulsões de vida, identidade, complexo de Édipo, angústia.

Objetivo do Texto: Compartilhar as experiências, a significação e a compreensão dos processos vivenciados pelos entrevistados para a superação da dor psíquica. E dar esperança de vida, desafiando a idéia de que “... ser portador significa um fim” (p.21).

Linha Teórica: Freudiana e Kleiniana.

Conclusões: A autora analisa cada história de vida e de infecção pelo HIV, buscando compreendêla à luz da psicanálise. Considera que, através do processo psicanalítico, pode-se encarar a angústia, compreendê-la e superar os fantasmas associados a ela. Ressalta que cada um, individualmente, vive o próprio processo, porém o compartilhamento, favorece a superação da dor.

Num primeiro momento, os entrevistados vivenciaram uma sensação de dar de cara com a morte, com a vulnerabilidade, com a finitude. Para compreender as conseqüências disso, a autora lança

referido) 
mão do conceito de pulsão de morte, que impele o indivíduo a uma ausência de tensão e estímulos (fuga da vida), contrapondo-se às pulsões de vida, representadas pela sexualidade e busca de prazer, que lança o indivíduo na luta pela vida, à criação, ao novo.

Diante da revelação do diagnóstico, o espaço privado do indivíduo torna-se público. O corpo médico passa a saber dele, assim como toda a sociedade. Há que se criar, neste momento, espaço para o ódio, a dor e outros sentimentos, todos ligados à identidade do portador, seus conflitos e desorganizações. "Repentinamente, o indivíduo não sabe mais quem é. A revelação do oculto contamina tudo e só resta uma certeza: sou aquilo que não deveria ser" (p.19) (destaque da autora). As defesas psicológicas sofrem um abalo, abalando também as defesas imunológicas, deixando o indivíduo mais vulnerável a ataques tanto internos, quanto externos.

A autora dedica um capítulo a considerar "A gestação sob o signo da aids", baseado no depoimento de Ana, uma das entrevistadas que, sabendo-se grávida, opta por ter o filho, a despeito das contraindicações de seu médico. Trata da questão da resolução do Complexo de Édipo dessa mãe, na sua história particular, na qual, a possibilidade de gestar uma criança com chances de ser HIV negativa, “... pode ser vivida como uma reparação do dano causado à sua mãe pelo desejo de ocupar o seu lugar (...) e confirmar que nada foi destruído" (p.120). Do ponto de vista da consciência, vive o perigo real da doença e da morte, da própria morte por aids, mas, inconscientemente, o bebê representa a significação da vida, o seu renascer, a sua continuidade, o ser. SANCHES leva em conta, em sua análise, o mecanismo de idealização do bebê, que vinha salvar tudo na vida da paciente, e que foi responsável, inclusive, pelo fortalecimento de seu sistema imunológico e pela busca do conhecimento atualizado dos médicos que cuidavam dela. Todos investiram na nova vida. Analisando a questão da não prevenção da aids pelo não uso do preservativo, SANCHES considera que o funcionamento do psiquismo humano é irracional sob a ação da angústia. Não pensar no perigo, para fugir do que é assustador, é o que deixa o sujeito mais vulnerável. Pelo contrário, admitir a ameaça da aids, pode deixar o sujeito em melhores condições de enfrentá-la, pois pensará a respeito. "Não se pode negar que a aids é um risco, mas se este for visto como algo a ser enfrentado, aumenta a probabilidade de resistência" (p.131).

SANCHES (1997) descreve o mecanismo que impede a mulher de sugerir o uso do preservativo ao seu parceiro, no qual, “... idéias que geram angústia tendem a ser evitadas. FREUD mostrava que o psiquismo humano procura diminuir tensão. Quando esta é gerada externamente, podemos fugir. Mas, quando vem de dentro, é preciso recorrer a recursos psíquicos como os mecanismos de defesa. Atacar a capacidade de pensar é um dos mais comuns. A pessoa emburrece, de uma forma geral ou específica. É um recurso comum na vida de todos nós - não quero nem pensar nisso.... Pensar é uma forma de entrar em contato com o objeto. Quando o contato gera angústia, fica impossível pensar. Não são muitas as mulheres que têm coragem de dizer não ao desejo próprio e do outro e, em nome da racionalidade, colocar em risco o relacionamento" (p.132) (destaques da autora). 
Os homens, por sua vez, lidam com a aids e o preservativo com fantasias ligadas à homossexualidade ou à perda da potência e do prazer, o que os impede de praticar sistematicamente a prevenção. "Numa sociedade marcada pelo narcisismo, perder a ereção representa uma ferida na auto-estima" (p.133). Além disso, inconscientemente, o ser humano sentese imortal, nada o atingirá. Então, para que se proteger? O uso do preservativo poderia funcionar como um ataque à onipotência e à imortalidade.

Por outro lado, faz parte do psiquismo a pulsão de morte, que, ao contrário de negar a morte, vai em busca dela. E isto é tanto mais freqüente quanto mais o psiquismo está desorganizado. A destrutividade remete a si mesmo, mas também ao outro. Isto é mostrado claramente no depoimento do capítulo 5, cujo entrevistado SANCHES denominou de José Roberto.

Quanto aos homens casados, bissexuais, com dificuldade de assumir sua homossexualidade para não destruir a imagem construída de si próprios, o uso do preservativo significa colocá-los frente a frente com esse lado oculto. Coisa da qual se esquivam. Assim, atacam (inconscientemente) a si mesmos, à esposa e à prole. Analisando Kleinianamente, SANCHES sugere que, a inveja que o homem tem da mulher gerar filhos, em contrapartida à inveja do pênis pela mulher, acrescida da ascensão da mulher que cada vez ganha mais poder na sociedade, podem representar uma ameaça para o homem. A figura feminina pode se tornar ameaçadora, apesar de desejada. "E tudo o que ameaça é objeto de ataque...” (p.136). O indivíduo, não assumindo sua bissexualidade, pode vivenciar a culpa consciente ou inconscientemente, e ficar sujeito à infecção pelo seu não enfrentamento e não proteção contra o HIV.

No capítulo em que analisa o papel dos médicos e demais profissionais de saúde, a autora compara, através dos depoimentos, o quanto a forma como foi transmitido o diagnóstico ao portador foi significativa para a assimilação do mesmo, e a continuidade da vida. Constatou que os pacientes, de maneira unânime, esperam que os médicos os vejam como pessoas inteiras, que precisam ser ouvidas e respeitadas, podendo ter um papel ativo no tratamento e provocar mudanças. Assim, têm possibilidade de recuperar sua força de vida e enfrentar melhor os ataques que virão de dentro e de fora.

SANCHES considera que o indivíduo, em algum momento, é invadido pela aids mental (estando ou não infectado) e que esta é reflexo de como a sociedade significou a aids, com estigma, preconceito e condenação. O grau de influência do estado de aids mental no indivíduo dependerá de sua estrutura psíquica e história de vida, mas sempre está presente a angústia e a culpa como eixo comum a todos os entrevistados.

A autopunição é um dos caminhos que se toma, mas também se pode tomar o caminho do ataque ao outro, ao exterior, às vezes indo de um para outro. A autora sugere o binômio vítima-algoz que aprisiona e mantém o sujeito pendurado em uma ou outra posição.

O quadro de aids mental é dominado pela pulsão de morte. A saída só é possível através da elaboração dos conteúdos num espaço compartilhado, onde possa emergir a pulsão de vida que será 
responsável pela força para o enfrentamento da situação, pelo resgate das ilusões de cada um.

"As entrevistas apresentam saídas do túnel da aids mental: renúncia, aceitação de limites e perdas, elaboração do luto, perdão, reparação, sublimação. São processos psíquicos que exigem um enorme trabalho, impossível sem a ajuda externa" (p.168).

Sugestões: A partir dos depoimentos, a autora sugere várias fontes de ajuda aos portadores e doentes de aids:

a) Os médicos e profissionais de saúde devem ocupar um lugar que não seja extremamente rígido e preso a padrões de tratamento, nem muito próximo e "contaminado" pela angústia do paciente. Devem atentar para a forma como vai inquirir sobre a intimidade do paciente que não deve ser mais uma fonte de stress para ele, dentro das tantas que já está vivenciando. O mesmo cuidado deve ser tomado na sala de espera dos serviços.

b) $\mathrm{O}$ atendimento psicanalítico poderia ser inserido no serviço público, ampliando o número de pessoas que se beneficiariam dessa abordagem.

c) O grupo de ajuda, no caso dos entrevistados, foi um espaço compartilhado positivo, auxiliando a ressignificação das situações apresentadas. São também boas fontes de informação sobre a doença e suas formas de prevenção.

\section{Indicação bibliográfica:}

Costa JF. A inocência e o vício: estudos sobre o homoerotismo. Rio de Janeiro: Relume-Dumará; 1992.

\section{FICHA TÉCNICA - TEXTO $38^{*}$}

Autor: Renate Meyer Sanches

Instituição: Pontifícia Universidade Católica de São Paulo - Faculdade de Psicologia e Programa de Estudos Pós Graduados em Psicologia Clínica: Laboratório de Psicopatologia Fundamental Local: São Paulo

Ano: 1997

Título: A relação médico-paciente sob o signo da aids

Tipo de Produção: Artigo

Fonte: Revista USP. 1997; 33 (Dossiê Aids): 47-55

Instituição Envolvida: Grupo de apoio à aids não identificado (C.P.A.- nome fictício)

Tema Principal: A relação médico-paciente

Sub-temas:

a) Uso da medicação AZT (significado para os pacientes)

b) Formas de comunicar o resultado soropositivo

c) Preconceito 
d) Homossexualidade

e) Apoio ao profissional médico frente à impotência diante da aids (supervisão)

Objeto do Texto: A relação médico-paciente sob o signo da aids.

Conceitos abordados: experiência traumática, ressignificação da vida, angústia. Apesar de não usar textualmente, estão implícitos os conceitos de transferência e contratransferência.

Objetivo do Texto: Refletir sobre a especificidade da relação do médico com o paciente de aids, enfocar os aspectos relativos à vivência e à significação dadas a certos procedimentos médicos e paramédicos pelos portadores do vírus HIV entrevistados pela autora. Tecer considerações sobre os dados coletados.

Linha Teórica: não explicitada

Conclusões: Frente aos depoimentos, a autora levanta algumas questões que surgem da forma como a relação médico-paciente se processa, cujas respostas considera-se como conclusões:

O resultado positivo, decodificado como uma consideração à exclusão, à degradação e à morte num primeiro momento, ameaça desabar o mundo do sujeito, mas não desaba, pois há o outro que é capaz de ressignificar a situação (o médico).

"O mesmo profissional, cuja postura 'objetiva' e distante em relação ao paciente homossexual foi vivida como um violento ataque por esse, mostrou-se extremamente continente e sensível quando lidou com uma paciente não pertencente aos grupos de risco socialmente estigmatizados. É muito difícil evitar que os preconceitos, baseados em pré-conceitos culturalmente estabelecidos, aliados a questões pessoais de cada profissional afetem a relação. São questões geralmente não-conscientes para os envolvidos que, exatamente por isso têm uma ação mais intensa e profunda" (p.51) (destaques da autora). Isto pode ser evitado, através da tomada de consciência desses aspectos.

"O lugar que o sujeito imagina ocupar para o profissional (...) começa a ser situado na sala de espera e se prolonga no inquérito..." (p.52) ao qual é submetido. A autora sugere que se atente para a forma como o inquérito é feito, utilizando tato, tentando se colocar no lugar do paciente, controlando a curiosidade que, às vezes, tem mais a ver com as fantasias do profissional do que com o paciente.

O AZT muitas vezes é prescrito pela impotência desencadeada pela aids. Para o paciente isto pode ser vivido como o fracasso diante da doença. Deve-se avaliar adequadamente o momento de iniciar a medicação e explicar os motivos para o paciente.

"Aceitar o uso de recursos alternativos propostos pelo paciente (...) melhora significativamente a relação médico-paciente...” (p.55), na medida em que mostra que o médico admite um outro tipo de saber (o do paciente) e dá um certo poder ao paciente, tirando-o da condição de impotência.

"O que o paciente procura num profissional de saúde é a esperança e o reconhecimento de que existe nele, sujeito, uma força de vida. Uma possibilidade de se fortalecer para enfrentar os ataques

\footnotetext{
* O texto é recheado de fotos de quadros que a autora associou aos temas abordados. Os textos de n ${ }^{\circ} 37$ e 50
} 
que virão, de dentro e de fora. Procura alguém que não tema chegar perto da dor e da angústia que carrega. Mas que não se contamine com ela a ponto de ficar paralisado (...) alguém que o respeite e ouça, para ser também ouvido. Um profissional que seja, como disse Betinho, um amigo" (p.55) (destaque da autora).

Sugestões: Algumas conclusões já contemplam sugestões. A autora enfatiza a necessidade de troca de experiências entre os profissionais que trabalham com aids fornecendo o compartilhamento das angústias e o suporte, se possível com a presença de um supervisor, alguém distanciado da rotina. Isto enriqueceria o trabalho do profissional e daria mais qualidade ao atendimento dos pacientes. Indicação Bibliográfica: Não foi encontrada referência de interesse para o presente estudo.

\section{FICHA TÉCNICA - TEXTO 39}

Autor: Renata Cruz Soares de Azevedo

Instituição: Centro Corsini

Local: Campinas - SP

Ano: 1997 (evento) 1998 (publicação)

Título: Segunda Fala

Tipo de Produção: Comunicação em evento

Fonte: Jornada Psicanálise e Aids; 1997 jun 28; Campinas, São Paulo. Campinas: Escola Lacaniana de Psicanálise de Campinas; 1998, p.9-15.

Instituição Envolvida: Centro Corsini

Tema Principal: Reações específicas de cada sujeito frente ao conhecimento de sua soropositividade. Apoio ao paciente pelo profissional neste momento.

Objeto do Texto: Discussão da questão do impacto do diagnóstico de HIV/AIDS para o indivíduo. Conceitos abordados: mecanismos de defesa, luto e perda de objetos, modos de subjetivação.

Objetivo do Texto: Trazer para a discussão aspectos do atendimento a portadores do HIV ou doentes de aids, no momento inicial do confronto com o diagnóstico.

\section{Linha Teórica: Lacaniana}

Conclusões: A autora relembra o controle adquirido sobre as doenças venéreas que permitiu uma maior liberdade de "usufruto" do corpo, constatando que a Aids reaviva antigos terrores. Comparando a Aids e a sífilis, AZEVEDO considera que a Aids traz à tona questões relativas à intervenção médica, legal e moral no combate de uma doença, pois incide em pontos sexualidade, medo do contágio, decadência e possibilidade de morte coletiva - que envolvem representações sociais muito amplas.

A lógica do medo e da insegurança preside a reação à possibilidade, ainda que hipotética, de ter contraído a doença.

do presente estudo são da mesma autora e contém teorizações mais extensas sobre o tema tratado. 
Existem algumas razões que tornam o diagnóstico do HIV/AIDS assustador: ser alvo de preconceitos e discriminação por parte das pessoas em geral, ter que decidir se assume ou não a condição de soropositivo, “... sentir o efeito da bomba relógio e ainda o de ter um vírus que se pode transmitir nas relações sexuais..." (p.11), contrair doenças oportunistas, sentindo a saúde degradarse, vivenciar a impotência médica frente à doença, as decisões políticas referentes a ela e, por fim, ser culpabilizado pela sua doença.

“... o significado pessoal e subjetivo que a doença física desperta, parece ser o fator fundamental modulado por características de personalidade, circunstâncias sociais e pela natureza da patologia e seu tratamento, para a reação de pacientes ao adoecimento" (p.11).

Cada paciente lida, à sua maneira, com a dor e o sofrimento físico e psíquico, estabelecendo uma relação particular com o médico, com o adoecimento e com a possibilidade de morrer que deve ser respeitada pelo profissional que o assiste. São várias as possibilidades de subjetivação dos pacientes. Portanto, a forma de se defrontar com a doença e com a morte depende da maneira como a pessoa vive, como utiliza os mecanismos de defesa frente às situações de crise, o que vai determinar suas manifestações psicológicas, dentre elas, o luto pela perda de objetos de amor e da própria auto-estima. A morte de que se fala aqui, não é apenas biológica, mas também simbólica.

Sugestões: Não há

Indicação bibliográfica: Não há referências no texto.

\section{FICHA TÉCNICA - TEXTO 40}

Autor: Leila Macieira Barbosa

Instituição: Centro Corsini

Local: Campinas - SP

Ano: 1997 (evento) 1998 (publicação)

Título: Terceira Fala

Tipo de Produção: Comunicação em evento

Fonte: Jornada Psicanálise e Aids; 1997 jun 28; Campinas, São Paulo. Campinas: Escola Lacaniana de Psicanálise de Campinas; 1998, p.16-8.

Instituição Envolvida:Centro Corsini

Tema Principal: Impacto do diagnóstico de HIV

Objeto do Texto: Impacto do diagnóstico de HIV/AIDS

Conceitos abordados: processos mentais inconscientes: fantasias, mecanismos de defesa e relações de objeto.

Objetivo do Texto: Levantar hipóteses sobre os processos mentais inconscientes dos pacientes portadores do HIV ao receberem o diagnóstico e apresentar as fantasias, angústias e defesas que podem ser mobilizadas naquele momento.

Linha Teórica: Kleiniana 
Conclusões: A autora lança mão de algumas vinhetas clínicas nas quais baseou suas interpretações, concluindo que, no momento em que recebem a comunicação do diagnóstico de HIV, os pacientes sentem um grande abalo acompanhado de angústia acentuada. Essa é decorrente da infecção ser percebida como um "objeto persecutório aniquilador", que, muitas vezes, é negado, como uma forma de afastar o "mau objeto" do "bom objeto". Os mecanismos de defesa são utilizados para lutar contra as angústias persecutórias de fragmentação, perseguição e depressão atribuídas ao HIV. O suporte psicológico é fundamental para auxiliar na reorganização da estrutura emocional que ficou alterada com o saber da soropositividade, que faz reviver situações primitivas da vida do indivíduo, pertencendo ao mundo interno de cada um.

Sugestões: A autora espera que a sua experiência possa contribuir para o campo dos estudos psicodinâmicos, tanto para pesquisa como para atuação.

Indicação bibliográfica: Não há referências no texto.

\section{FICHA TÉCNICA - TEXTO 41}

Autor: Mauro Mendes Dias

Instituição: Escola Lacaniana de Psicanálise de Campinas

Local: Campinas - SP

Ano: 1997 (evento) 1998 (publicação)

Título: Primeira Fala

Tipo de Produção: Comunicação em evento

Fonte: Jornada Psicanálise e Aids; 1997 jun 28; Campinas, São Paulo. Campinas: Escola Lacaniana de Psicanálise de Campinas; 1998, p.2-8.

Instituição Envolvida: Consultório privado.

Tema Principal: Escuta do sujeito, do seu inconsciente. Sexualidade.

Objeto do Texto: Afirmando que não existe sujeito aidético, o autor aponta o seu interesse pela maneira como o indivíduo, que contrai o vírus HIV, vai responder face à nova presença. Interessa saber qual a economia inconsciente que passa a operar, não recobrindo o sujeito totalmente pelo diagnóstico como faz o discurso médico.

Conceitos abordados: sujeito do desejo, sexualidade, alienação.

Objetivo do Texto: Dialogar sobre o tema, considerando um posicionamento da clínica psicanalítica de considerar a dimensão do sujeito e sua relação com o seu desejo, sem tomar como foco central a sua patologia orgânica (no caso, a aids).

\section{Linha Teórica: Lacaniana}

Conclusões: Nenhuma doença consegue recobrir a dimensão da sexualidade e da relação do sujeito com o próprio desejo, o que restitui ao indivíduo portador do HIV/AIDS a mesma dimensão que todos os outros sujeitos têm. 
O diagnóstico de HIV/AIDS coloca o sujeito como objeto de investimentos de pessoas e serviços, dando-lhe um lugar na vida antes não experimentado, a partir do qual ele interroga as relações de alienação com o próprio desejo.

Há a possibilidade de uma reordenação dos laços do sujeito com a própria existência que vai permitir o benefício dos tratamentos que se submeterá.

“... o sujeito se cansa do tratamento". Essa afirmação diz respeito às dificuldades de seguimento do tratamento de aids, que exige um controle e disciplina muito grande, limitando a vida do paciente. Segundo DIAS, a aids é um "álibi” que o sujeito vai utilizar frente aos seus impasses com o próprio desejo, “... como se, em não havendo a aids, ele não teria os problemas que passa a ter, a partir de então" (p.6).

Um terceiro elemento entra na relação transferencial que é o médico, pois “... se a aids é uma forma contemporânea do sujeito atualizar os impasses com o próprio desejo, [é também] um elemento real e não apenas fantasmático..." (p.6): uma doença que não tem cura, mas que, também, mobiliza um fantasma.

O abandono do tratamento, para DIAS, tem a ver com o fato de que o ser humano não é propenso a querer se cuidar, a querer viver bem e a se curar.

Com a aids, a relação do sujeito com o corpo muda. Antes, lugar de realização de prazer, agora passa a ser lugar de perdas e limitações pelas infecções que o acometem, tornando-se, então, um lugar de realização de cuidados.

Sugestões: Continuação dos trabalhos desenvolvidos em Centros como o Corsini (parceiro na realização do evento), visando uma atenção ao paciente que o ajuda a evitar o isolamento decorrente das dificuldades que a aids acarreta.

Indicação bibliográfica: Não há referências no texto.

\section{FICHA TÉCNICA - TEXTO 42}

Autor: Maria Teresa Guimarães de Lemos

Instituição: Escola Lacaniana de Psicanálise de Campinas

Local: Campinas - SP

Ano: 1997 (evento) 1998 (publicação)

Título: Quarta Fala

Tipo de Produção: Comunicação em evento

Fonte: Jornada Psicanálise e Aids; 1997 jun 28; Campinas, São Paulo. Campinas: Escola Lacaniana de Psicanálise de Campinas; 1998, p.19-22.

Instituição Envolvida:Trata-se de uma reflexão teórica

Tema Principal: A entrada em contato com o tema da aids.

Sub-temas

a) Querer saber/não querer saber 
b) Divisão entre saber e verdade, que a psicanálise mostra nunca se recobrirem.

c) Desejo do sujeito, desconhecimento e reconhecimento do desejo.

Objeto do Texto: Questão do saber/não saber/não querer saber sobre a condição sorológica pelo analista.

Conceitos abordados: lapsos, recalque, objeto, desejo.

Objetivo do Texto: Refletir sobre a subversão do discurso do sujeito através do lapso, revelando uma verdade que não se quer reconhecer.

Linha Teórica: não explicitada.

Conclusões: A partir de seu contato com o tema da aids, a autora constata sua dificuldade de saber sobre a própria condição sorológica e relata a forma como lidou com isso. Considera que, através do discurso e da sua subversão, pode-se identificar o desejo do sujeito, até então, desconhecido, ressignificando alguns sentidos, dentre eles a própria posição do analista. Nesta perspectiva, o outro é incluído como objeto de desejo, mas também como risco de infecção. Portanto, insere-se no "não querer saber" e no "saber e mesmo assim não querer saber". Em outras palavras, o saber do diagnóstico negativo não elimina o sentimento de desconfiança na relação com o outro e esta contradição é acompanhada da recusa de querer saber da condição do outro, o que torna o ato sexual um ato de risco de infecção.

Sugestões: Não há

Indicação bibliográfica: Não há referências no texto.

\section{FICHA TÉCNICA - TEXTO 43}

Autor: Ana Cleide Guedes Moreira

Instituição: Universidade Federal do Pará e Pontifícia Universidade Católica de São Paulo Programa de Estudos Pós-Graduados em Psicologia Clínica - Núcleo de Psicanálise - Laboratório de Psicopatologia Fundamental.

Local: São Paulo-SP

Ano: 1998

Título: Eros, melancolia, aids: sobre alguns problemas da clínica contemporânea

Tipo de Produção: Artigo em periódico - Seção Temática

Fonte: Correio da APPOA 1998; 63: 24-31.

Instituição Envolvida: Reflexão a partir da clínica em consultório privado

Tema Principal: Problemas da clínica contemporânea com pacientes com HIV/AIDS.

Sub-temas: .. Eros. Melancolia

Objeto do Texto: Análise da problemática do atendimento psicoterapêutico ou psicanalítico de pacientes com diagnóstico positivo para HIV ou aids.

Conceitos abordados: transferência, resistência, melancolia, Eros, investimento narcísico.

Objetivo do Texto: Debater sobre a clínica da aids; Refletir sobre o quanto o analista está preparado 
para enfrentar a realidade de que a cada 20 minutos uma pessoa está sendo infectada.

Linha Teórica: Freudiana, cita também Maud MANNONI.

Conclusões: O analista, ao se defrontar com o inesperado do que é trazido pelo paciente soropositivo pode incorrer em perigos do tipo: vivenciar um misto de terror e piedade, mergulhar em sentimentos de raiva, revolta, ou cair paralisado, numa espécie de luto antecipatório pensando que breve este cliente o abandonará. Pode também entrar num tipo de "furor terapêutico", querendo conservar a vida do paciente e sentir-se culpado pela sua doença, semelhante ao que FREUD chamou de "culpa do sobrevivente" (destaque da autora).

Há um longo caminho a ser percorrer para a identificação e teorização das novas figuras que a aids vem constituindo (p.28).

MOREIRA faz a associação entre os fatores que levam a uma queda nas defesas imunitárias, tendo como um dos principais o stress e a melancolia decorrentes da comunicação do diagnóstico. Assinala a dificuldade de se fazer uma escuta, quando se mesclam a resistência (no sentido analítico do termo), o mal-estar e dor orgânicos, impeditivos reais. A ameaça à integridade do sujeito não é só imaginária, mas concreta, real.

O diagnóstico da depressão, nestes casos, é complexo pois os sintomas tanto podem ser decorrentes da presença da aids, quanto do processo patológico primário subjacente. Como atribuí-los a uma ou ao outro? Em conseqüência, como esperar que o sujeito esteja adequado às exigências do tratamento, tão rigorosamente estabelecido de ingestão de medicação, se está envolvido pela melancolia, destituído de investimento narcísico, de amor próprio e desejo de viver? Neste ponto, a autora cita a concepção de melancolia de FREUD e a diferencia do fato de o doente estar com aids, mas ter seu amor próprio preservado, pela ausência da melancolia, condição necessária para um tratamento clínico, não necessariamente psicológico.

"Eros, aquele que é invocado em todo ato de ajuda presente no ofício clínico, e que sucumbe onde a melancolia instala-se, geme, acossado por mortíferas ameaças. Hoje em dia (...) a possibilidade de fazer amor, coloca novos perigos, a aids o atesta. Temos razões de sobra para muita melancolia, e essa também não falta no panorama atual. Tempos sombrios ${ }^{2}$ estes" (p.31).

Sugestões: não há

Indicação Bibliográfica:

Sanches, R.M. Escolhi a vida. Desafios da Aids Mental. São Paulo, Ed. Olho D’água, 1997.

Seffner, F. $O$ jeito de levar a vida, trajetórias de soropositivos enfrentando a morte anunciada. UFRGS, Porto Alegre, 1995 (mimeo).

\section{FICHA TÉCNICA - TEXTO 44}

\footnotetext{
${ }^{2}$ MOREIRA empresta o termo de Hanna ARENDT e de Jurandir Freire COSTA que o utilizou em: Narcisismo em tempos sombrios. In: Fernandes HR. Tempo do Desejo. Sociologia e Psicanálise. São Paulo, Brasiliense, $2^{a}$. Ed., 1991.
} 
Autor: Maria Elisa Pessoa Labaki

Instituição: Laboratório de Psicopatologia Fundamental do Programa de Estudos Pós-Graduados em Psicologia Clínica da Pontifícia Universidade Católica de São Paulo.

Local: São Paulo

Ano: 1998

Título: A situação do desamparo e a aids*

Tipo de Produção: Artigo em periódico - Seção Temática

Fonte: Correio da APPOA. 1998; 63: 32-8).

Instituição Envolvida: Casa da Aids, serviço ligado à Faculdade de Medicina da Universidade de São Paulo.

Tema Principal: Desamparo e aids. Psicoterapia de pessoas portadoras do HIV ou doentes de aids.

Objeto do Texto: Reflexão e elaboração da experiência como psicoterapeuta de pessoas recém informadas de sua condição de portadoras do vírus da aids.

Conceitos abordados: desamparo fundamental, angústia de morte, representação da morte no inconsciente, recalque, negação e duplo.

Objetivo do Texto: Refletir sobre os efeitos psíquicos nos pacientes que nada demandaram sobre si, mas que foram "chocados" pelo médico com uma revelação sobre seu próprio destino e a relação disso com o desamparo.

Linha Teórica: Freudiana

Conclusões: “... a situação de desamparo está, imediatamente, referida à impossibilidade do sujeito pensar, ou dar palavras, a uma experiência pela qual ele nunca passou (...) predominava a ausência de representação e, aqui, a situação de desamparo parece efeito do choque pela impossibilidade de sentir e pensar" (p.34-5).

Outros pacientes vivenciavam uma espécie de transbordamento de representações da aids. Por causa do excesso, essa vivência era traumática, exigindo elaboração. Parecia haver uma contaminação de todos da equipe, com excesso de representação que levava à angústia e dor. Exacerbava-se o medo de perda do amor do Outro, resgatando a condição humana do desamparo.

Associando a aids ao filme "a bela e a fera" de Jean Cocteau, a autora conclui que: “... o processo psicoterapêutico pode possibilitar a passagem de um estado passivo de sofrimento, pelo desamparo e solidão, para um estado de agenciamento da própria condição de sujeito desejante e vulnerável que é, aos riscos da vida" (p.37).

Doente e psicoterapeuta podem representar duas faces complementares e especulares de uma só imagem. Utilizando o conceito de duplo de Freud, a autora considera que "... um vê emergir no outro sua face sombria e estranha, (inquietantemente familiar). Mas, também, a face desejante e

\footnotetext{
* Resumo do trabalho de igual nome apresentado no Congresso Brasileiro de Psicopatologia Fundamental, em 25 de abril de 1998, em São Paulo. Este texto foi publicado, com algumas modificações na Pulsional Revista de Psicanálise. 1999; (119): 17-27. (É o texto 48 do presente estudo).
} 
generosa, resultado da transformação do que é traumático, em possibilidade de vida.” (p.38)

Sugestões: Estão implícitas nas conclusões

Indicação Bibliográfica: Não foi encontrada referência de interesse para o presente estudo.

\section{FICHA TÉCNICA - TEXTO 45}

Autor: Ricardo Pessoa Przemyslaw

Instituição: Não explicitada

Local: Não explicitado

Ano: 1998

Título: Sodoma e a Estátua de Sal Atual / Sexualidade na era da aids.

Tipo de Produção: Capítulo de livro

Fonte: In: Graña, Roberto Barberena (org). Homossexualidade: formulações psicanalíticas atuais. Porto Alegre: Artes Médicas, 1998 p. 217-30.

Instituição envolvida: Trata-se de uma reflexão teórica

Tema Principal: Psicanálise diante da aids. Sexualidade.

Sub-temas:

a) Homossexualismo / Homoerotismo

b) Perversão

c) Identidade sexual

d) Moral sexual civilizada

Objeto do Texto: Articulação da complexidade do fenômeno aids com uma visão psicanalítica.

Conceitos abordados: Perversão, compulsão, identidade sexual, moral sexual civilizada, narcisismo.

Objetivo do texto: Discutir as relações psicanálise-sexualidade-aids. Considerar qual referencial psicanalítico pode ser utilizado diante da plasticidade da realidade da sexualidade e do erotismo. Questionar que tótens nosológicos podem ser utilizados para observar essa realidade sem preconceitos. Trazer “... uma contribuição da teoria dos instintos, particularmente necessária para a compreensão desta ocorrência da destrutividade patológica que traz na sua gênese duas compulsividades: uma ao nível das práticas sexuais sob o signo do êxtase total e ilimitado, outra, ao nível somático, mais especificamente do sistema imunológico."

Linha teórica: freudiana e lacaniana

Conclusões:

O autor desenvolve seu texto tentando não estabelecer qualquer postulação normativa em torno da consideração da perversão / compulsão apenas em termos pulsionais.

Neste sentido, o homossexualismo não é tomado como perverso em si: “... vamos reservar a categoria de perversão para as compulsividades que se marquem mais pelo gozo destrutivo, como, por exemplo, as promiscuidades sem nenhuma preocupação com a segurança tanto do sujeito como 
do(a) parceiro(a)."

Assinala também, as mudanças culturais rápidas e radicais com implicações na "moral sexual civilizada" que, segundo FREUD (1908), era responsável pelo aumento da doença nervosa na modernidade. PRZEMYSLAW discorre sobre o texto de FREUD, salientando o conflito do homem moderno para a satisfação pulsional, que muitas vezes pende para a transgressão dos princípios éticos e dos ideais em prol dos prazeres e do gozo total, fruto de um narcisismo alienante. Neste contexto, instalam-se as perversões, antes ocultadas, agora “... elementos de autopromoção no mercado erótico..." (p. 223) e no seu bojo, a aids, revelando de forma trágica as conseqüências do prazer sem limites que o autor associa à Sodoma e Gomorra em versão atual. Ainda citando FREUD, destaca-se a falta de possibilidade de conciliar os instintos com a norma social, que cria uma moral "dupla": a visível, que concilia os interesses do sujeito com a sociedade, e o cinismo, que impossibilita essa conciliação. O autor acrescenta ainda, a questão do narcisismo legitimado na subversão individualista do sujeito para se defender da massificação. “... o século XX promoveu uma reconquista do corpo erógeno, ainda que fragmentado pelas identificações projetivas, bastante primitivas e vorazes, na verdade definindo um padrão antropofágico para as relações do mercado erótico em que vivemos." (p. 224)

Nessa espécie de palco, as doenças sexualmente transmissíveis podem se desenvolver na compulsividade e promiscuidade.

"O momento cultural já era catastrófico, e a aids veio conferir uma de suas notas mais trágicas." (p. 225) O autor considera, entretanto, que o século XX foi o mais "relacional" que já houve, apesar do narcisismo e da cultura de sobrevivência, do mínimo eu (concordando com LASCH).

A aids trouxe preocupações com o sexo seguro e considerações com o outro. Neste ponto, o autor assinala o apelo de LACAN para o Outro, com O maiúsculo, tendo um lugar fundante no psiquismo do sujeito. Possui uma função na formação dos ideais do ego, através dos problemas com que se defronta, permitindo uma reorganização ou amadurecimento do sujeito.

A aids trouxe um "choque narcísico" influenciando a ética dos tempos atuais.

$\mathrm{O}$ autor ressalta o caráter de normalidade da polimorfia perversa desde as primeiras formulações psicanalíticas sobre a sexualidade.

Quando articula perversão e compulsão considera que a patologia é sua sujeição aos instintos de morte, cuja força destrutiva pode aniquilar a estrutura do sujeito ou a do Outro.

PRZMYLAW aponta ainda, a questão do sistema imunológico, que é seletivo aos seus agentes invasores. Supondo uma certa capacidade de "pensar" da célula que tem defesas específicas para cada agressor, “...o sistema imunológico é um depositário da memória das lutas intercelulares da história do indivíduo. E é um sistema que aprende, seja naturalmente, seja induzido por vacinas." Complementa com a hipótese de que, sendo a promiscuidade determinante do fenômeno, a pulsão de morte também o é, pois tende ao retorno da excitação ao nível mais baixo possível, mesmo que de forma auto-agressiva atinja o sistema imunológico. Está aí a base da suposição do 
desenvolvimento da doença auto-imune.

Hoje se admite a prática sexual para fins de obtenção de prazer e não exclusivamente, com fins de reprodução. Entretanto, nem sempre se consegue esse intento, que acaba se buscando desenfreadamente - pela norma atual permissiva - pelo Outro que obture a falta. $\mathrm{O}$ autor indaga: “... não estaria o Outro se instituindo como uma simulação do outro, pouco mais que uma projeção a serviço do gozo narcísico, e não teria a moral sexual que se 'sofisticar' para conter mais um cinismo?" (p. 229)

Sua questão se refere ao risco de tomar identificações projetivas por verdadeiras relações com o Outro. E, como analistas, pode-se interpretar as relações no nível intrapsíquico e interpsíquico, inclusive as relações da psique-soma. Não se pode excluir o sistema imunológico, apesar da tendência a ignorá-lo. Conclui: "Não há justificativa ética para a sonegação científica. Nossos clientes não estão precisando de estátuas. Estão precisando de práticos.” (p. 230)

Sugestões: não há

Indicação bibliográfica: Não foi encontrada referência de interesse para o presente estudo.

\section{FICHA TÉCNICA - TEXTO 46}

Autor: Renate Meyer Sanches

Instituição: Pontifícia Universidade Católica - SP

Local: São Paulo

Ano: 1998

Título: A aids numa cultura de falsos-selves.

Tipo de Produção: Artigo

Fonte: Revista Latinoamericana de Psicopatologia Fundamental. 1998; 1(2): 107-22.

Instituição Envolvida: trata-se de trabalho teórico

Tema Principal: A cultura do falso self

Sub-temas:

a) O narcisismo

b) O mínimo eu

c) Aids social como um produto dessa cultura

Objeto do Texto: situar o significado dos mitos e tabus na visão de cultura de FREUD e WINNICOTT e, nesse contexto, a forma como a aids se insere.

Conceitos abordados: desamparo, impotência, narcisismo, falso self, espaço transicional, espaço criativo.

Objetivo do Texto: Fazer uma discussão teórica das diferenças da visão de cultura em FREUD e WINNICOTT e, de que forma, insere-se a Aids Social, colocada como um produto e uma denúncia dessa cultura (portanto, como um sintoma).

Linha Teórica: Freudiana e Winnicottiana. 


\section{Conclusões:}

A autora tece considerações teóricas a respeito da inserção do homem na cultura e na contemporaneidade, segundo FREUD, WINNICOTT, LASCH, GREEN, LÉVI-STRAUSS, CALLIGARIS e outros, associando a questão da aids a alguns pontos dessas teorizações. Será feito um assinalamento suscinto destes pontos.

Aos mitos, considerando as ideologias políticas como também uma mitologia, a autora associa a Aids Social, identificada como “... um conjunto de crenças específico (...) de representações, préconceitos e preconceitos ligados ao significante aids [que] condena o indivíduo à morte social a partir do momento em que sua contaminação é constatada, numa reprodução moderna do que LÉVI-STRAUSS (1996) descreveu nas mortes por conjuro ou enfeitiçamento nas sociedades primitivas" (p.110).

Isto afeta psiquicamente o indivíduo infectado, podendo acelerar seu processo de adoecimento.

Frente ao indivíduo infectado ergue-se um "muro social" que o separa do restante da sociedade, como um estranho, um estrangeiro tal qual foi observado por PAIVA (1992).

$\mathrm{Na}$ cultura narcísica (LASCH) existe uma negação do passado e uma indiferença pelo futuro, havendo uma valorização do corpo, da beleza, da juventude que, ameaçados de perda, geram um vazio interior. É uma perda que não pode ser encarada. "A individualidade, que supõe uma história pessoal, amigos, família, um sentido de situação, transforma-se num bem de luxo. Constantemente ameaçado, o eu, para sobreviver, contrai-se num núcleo defensivo: o eu mínimo" (p.115).

$\mathrm{O}$ narcisismo permite a existência do ego o qual possibilita que a vivência das experiências e sensações sejam integradas. É essa função “... ego-narcísica [que cria] um primeiro anteparo imaginário ao estado inicial de impotência / desamparo (...) primórdios da vida psíquica.” (p.116)

Diante dos embates do mundo o ego vai se reduzindo ao mínimo e, cindido, uma parte se protege no desconhecimento. (FREUD)

Segundo WINNICOTT, o mesmo ocorre com o self que depende de um ambiente "suficientemente bom" para se integrar. (destaque da autora)

Quando isso não ocorre, há um desenvolvimento parcial ou falso, restando aos aspectos potenciais privados de expressão, a possibilidade do desconhecimento.

Segundo a autora, a aids apareceu nesse contexto, onde a cisão, quando extremada, gera produtos que ora a denunciam, ora ameaçam eclodi-la. Para ela, existe uma semelhança do ponto de vista sintomático, entre a personalidade narcísica, a estrutura falso-self e o indivíduo normótico (conceito desenvolvido por BOLLAS, 1992, para identificar o indivíduo absolutamente normal) "Trata-se de pessoas socialmente extremamente adaptadas, estáveis, seguras e extrovertidas (...) o que se opõe a um desinteresse absoluto pela vida subjetiva" (p.117). A autora assemelha, em decorrência disso, a "cultura do narcisismo" à "cultura de falso-selves".

Reduz-se o espaço da transicionalidade, de apropriação de produtos culturais e criativos, havendo uma valorização do aparente e do visível que substitui a ausência do espaço criativo. Esse 
fenômeno se observa tanto na relação mãe-bebê, quanto na relação mãe-cultura. Cria-se um vazio, onde referenciais pré-estabelecidos cumprem a função de dizer e ocultar, simultaneamente. A questão aids surge nesse contexto, protegendo o indivíduo de se afrontar com aspectos renegados de si mesmo, e é espelho - produto deformado de uma cultura cindida. Atuar sobre ela, no sentido de mudar significados e usos dos mesmos pode abrir espaço para que a dimensão transformadora do espaço transicional ganhe dimensões maiores." (p.119)

Há a denúncia do que era ocultado, o privado se torna público, se mistura a ele.

A aids provoca um desfazer de mitos criados para encobrir, como um "falso-self".

Cria “... rachaduras no muro social...” (p.120).

Sugestões: “... que a aids (...) abra possibilidades de vivências mais verdadeiras, questionando, conseqüentemente, essa própria cultura" (p.120).

Indicação Bibliográfica: Não foi encontrada referência de interesse para o presente estudo.

\section{FICHA TÉCNICA - TEXTO 47}

Autor: Fernando Luiz Cipriano

Instituição: Instituto de Psicologia - Área de concentração - Psicologia Social e do Trabalho.

Local: São Paulo

Ano: 1999

Título: Dinâmica das propriedades da sexualidade de 09 Pacientes HIV-Soropositivos em Dois Anos de Investigação.

Tipo de Produção: Dissertação de Mestrado.

Fonte: -

Instituição Envolvida: a mesma

Tema Principal: Processos / mecanismos de constituição de identidades

Sub-temas:

Sexualidade

Impacto em relação ao HIV na vida afetiva e sexual de nove pacientes.

Objeto do Texto: Modo de ser / funcionar dos pacientes quanto às representações e ao conjunto dos significados emocionais que organizam os conflitos apresentados pelos entrevistados.

Objetivo do Texto: Investigar como um dado significado da realidade e a infecção influenciam no modo de ser / funcionar do entrevistado.

Linha Teórica: Freudiana e conceitos desenvolvidos por Fábio HERMANN.

Conclusões:

a) “... a contaminação pelo HIV não é uma dádiva e não conduz, necessariamente, a um processo de crescimento e maturidade emocional. A situação apresenta-se de forma complexa, diversificada, heterogênea; é curioso como insistimos em simplificar determinadas situações, em reduzi-las a denominadores comuns." (p.128) Isto é o contrário da hipótese inicial do autor, que acreditava na 
possibilidade de amadurecimento emocional das pessoas a partir do diagnóstico HIV positivo.

b) Considerar o HIV como uma condenação (opondo-se ao item $a$ ) é mais comum de se encontrar entre as pessoas pesquisadas e entre a maioria dos seus parceiros, familiares, médicos, etc.

c) O autor, após os quatro anos em que desenvolveu sua pesquisa, considera que o HIV/AIDS não é nem dádiva, nem condenação. "É um fenômeno complexo, que atinge importantes esferas da vida individual e coletiva, um evento raro, uma condição, que pode se transformar numa doença ainda incurável. É isso, nada mais nada menos” (p.128).

d) CIPRIANO conclui que não se pode dizer se houve um processo de ressignificação das vivências afetivas e das condutas sexuais dos pacientes acompanhados; pois, as transformações dessas, fazem parte de um processo onde se deve focalizar a organização psíquica do paciente como um todo. “... é mais consistente buscar compreender o sentido de determinada 'atitude' tendo a organização psíquica como parâmetro do que atribuir aquela mudança ao fato daquele paciente estar contaminado pelo HIV.” (p.129) O autor confirma sua conclusão utilizando um caso clínico. O HIV não altera condutas e significados, quem o faz é a pessoa em função do seu modo de ser, do seu funcionamento psíquico.

e) $\mathrm{O}$ autor constatou que a infecção repercute de forma diversa em cada um, sem um padrão determinado. Em alguns casos estudados por ele, a soropositividade levou ao amadurecimento emocional e à conquista de um funcionamento psíquico mais eficiente, acelerando um processo. Em outros casos, a infecção foi essencial para a conquista da autonomia frente a referenciais de identidade. "A soropositividade arrebentou com um modo de ser cristalizado e aprisionador, revelou intenções, impediu o disfarce, forneceu a dimensão exata para cada experiência” (p.131). Obrigou o paciente a se haver com as próprias dificuldades. Em alguns casos, o HIV é assimilado ao processo de amadurecimento emocional já em curso, sendo mais um acontecimento em suas vidas, e, dependendo da forma de vivenciar do paciente, pode funcionar como um coadjuvante em suas atuações. A contaminação, para um dos pacientes, funcionou como um atestado às suas dificuldades, ao seu desequilíbrio emocional, sendo resultado de aspectos autodestrutivos já existentes, não sendo assimilada e nem desestabilizando um modo de ser. Para outro, deixou-o em suspenso, impedindo-o de agir. O paciente “...não sabe mais ser” (p.132).

f) Quanto ao conceito de Masculino e Feminino em Psicanálise, pesquisado em suas entrevistas, CIPRIANO considera que o ser humano mescla em si essas duas modalidades, havendo predomínio de uma delas, sem a exclusão da outra. Propõe critérios que possam oferecer outra perspectiva para além da normalização realizada pela psicanálise, perigosa segundo ele. Seria um outro modo de fazer psicanálise, promovendo uma coesão entre noções diversas e sirvam de norte para a intervenção clínica estabelecendo outros critérios de compreensão do ser humano. Menciona como exemplo de um desses modos o uso do termo hemoerotismo como proposto por COSTA (1992) e a noção de conjugalidade. Refletindo sobre a questão da orientação sexual como um tema marginal de sua pesquisa, Cipriano a coloca como apenas um dos elementos do complexo 
funcionamento humano. (destaque do autor)

g) Para CIPRIANO o processo de construção da identidade, resulta de mecanismos e processos que são responsáveis pela constituição do sujeito. Estes estão relacionados aos conflitos e conteúdos emocionais que dependem do ajuste entre si, do qual decorre a organização psíquica. Utilizando a noção inconsciente relativo (HERMANN) em que a ruptura de campo promove o choque entre representações, adotou a perspectiva de compreender o ajuste e a articulação das representações dos pontos de vista tópico, econômico e dinâmico. Dos conjuntos de representações / significados se estabelecem à correspondência ao padrão de organização psíquica dos nove pacientes pesquisados e referenciais de identidade que eles expressam. O autor chamou de "estratégia psíquica” aos modos de ser de cada paciente, encontrando diversas estratégias. Na sua opinião “... existem determinados aspectos do existir que são o resultado da totalidade da organização" (p.138). Os recursos psíquicos utilizados são: o direcionamento de determinada organização (quando os conjuntos de significados expressam a mesma forma de ser ou formas de ser que não se excluem), a sobreposição (a utilização de características comuns entre conjuntos de significados que se fortalecem) e a fixação (que promove a rigidez). A cada conjunto de significados estão associadas condutas produzidas por eles. O autor não desconsidera a perspectiva dos mecanismos identificatórios para a compreensão do processo de construção de identidades, mas propõe uma interdependência entre essa modalidade e a que descreve.

Sugestões: Que a psicanálise se preocupe e se debruce sobre o sujeito adulto e não somente teorize sobre a criança e o passado do adulto. Considera que o conceito de inconsciente relativo foi necessário para a conversão do método psicanalítico à pesquisa e que é possível criar novas formas de teorização e intervenção em psicanálise.

Indicação Bibliográfica: Não foi encontrada referência de interesse para o presente estudo.

\section{FICHA TÉCNICA - TEXTO 48}

Autor: Maria Elisa Pessoa Labaki

Instituição: Laboratório de Psicopatologia Fundamental do Programa de Estudos Pós-Graduados em Psicologia Clínica da Pontifícia Universidade Católica de São Paulo.

Local: São Paulo

Ano: 1999

Título: A situação do desamparo e aids*

Tipo de Produção: Artigo em periódico

Fonte: Pulsional - Revista de Psicanálise. 1999; 119: 17-27.

\footnotetext{
* Resumo do trabalho de igual nome apresentado no Congresso Brasileiro de Psicopatologia Fundamental, em 25 de abril de 1998, em São Paulo. Este texto foi publicado com algumas modificações no Correio da APPOA. 1998; 63: 32-8.
} 
Instituição Envolvida: Casa da Aids, serviço ligado à Faculdade de Medicina da Universidade de São Paulo.

Tema Principal:

Desamparo e aids

Psicoterapia de pessoas portadoras do HIV ou doentes de aids

Objeto do Texto: Reflexão e elaboração da experiência como psicoterapeuta de pessoas recém informadas de sua condição de portadoras do vírus da aids.

Conceitos abordados: desamparo fundamental, angústia de morte, representação da morte no inconsciente, recalque, negação e duplo.

Objetivo do Texto: Refletir sobre os efeitos psíquicos nos pacientes que nada demandaram sobre si, mas que foram "chocados" pelo médico com uma revelação sobre seu próprio destino e a relação disso com o desamparo.

Linha Teórica: Freudiana

Conclusões:

a) “...a situação de desamparo na aids está imediatamente referida à impossibilidade do sujeito pensar ou dar palavras a esta experiência pela qual ele nunca passou (...). No contexto da aids a situação de desamparo que vive o sujeito ao receber o diagnóstico parece, então, ser efeito do choque pela impossibilidade de sentir, pensar, em suma, representar mentalmente a absoluta desconhecida que é a morte...” (p.21-2). Nesse caso, havia uma escassez de representação. Era como se não houvesse uma demanda de análise e, por isso, até difícil de ser demandada.

b) Outros pacientes vivenciavam uma espécie de transbordamento de representações da aids. Por causa do excesso, essa vivência era traumática, exigindo elaboração. Parecia haver uma contaminação de todos da equipe, com excesso de representação que levava à angústia e dor. Exacerbava-se o medo de perda do amor do Outro, resgatando a condição humana do desamparo.

c) Associando o atendimento de uma paciente com aids ao filme "A bela e a fera" de Jean Cocteau, a autora descreve o espaço transferencial que permeou esse atendimento e a sensação de sofrimento e desamparo vivenciada. Com esta comparação a autora ilustra a recuperação da identidade perdida em decorrência das limitações físicas sofridas pela paciente, e a sua impotência como psicoterapeuta no início do atendimento.

Doente e psicoterapeuta podem representar duas faces complementares e especulares de uma só imagem. Utilizando o conceito de duplo de FREUD, a autora considera que “... um vê emergir no outro sua face sombria e estranha, (inquietantemente familiar). Mas, também, a face desejante e generosa, resultado da transformação do que é traumático em possibilidade de vida.”(p.26)

Sugestões: Implícitas nas conclusões

Indicação Bibliográfica: Não foi encontrada referência de interesse para o presente estudo.

FICHA TÉCNICA - TEXTO 49 
Autor: Juliana dos Santos Ruiz

Instituição: Pontifícia Universidade Católica de São Paulo - Programa de Estudos Pós-Graduados em Psicologia Clínica - Núcleo da Psicanálise

Local: São Paulo

Ano: 1999

Título: A aids e suas representações: possibilidades de elaboração.

Tipo de Produção: Dissertação de Mestrado.

Fonte:

Instituição Envolvida: Instituto de Infectologia "Emílio Ribas"

Tema Principal: Aids e suas representações.

Sub-temas:

Escuta das representações

Análise de casos clínicos

Objeto do Texto: Indagações clínicas a partir do atendimento a pacientes com aids.

Conceitos abordados: representação, identidade e realidade.

Objetivo do Texto: Cotejar a teoria e a prática clínica a partir da escuta das representações dos pacientes.

Linha Teórica: Freudiana e conceitos desenvolvidos por Fábio HERMANN: teoria dos campos da qual a função defensiva das representações (sustentação da identidade, de um lado, e da realidade, de outro) faz parte.

Conclusões:

A autora propõe Considerações Finais e não Conclusões, por julgar seu trabalho não fecha, mas lança questões sobre o tema.

Assim, aponta uma síntese dos dados com aspectos comuns observados nos quatro casos que acompanhou, dando uma “... amostra do funcionamento psíquico perante a aids" (p.141). Longe de fazer uma tipologia ou de elaborar um perfil psicológico do doente de aids, RUIZ pretendeu assimilar alguns pontos que se repetiram em cada sujeito pesquisado.

“O que é universal (...) é o funcionamento psíquico, o modo de operar da psique humana (...) a existência de uma superfície representacional que tem função defensiva e é sustentada pela crença, e que, no processo de análise, é posta em xeque em diversos pontos. Como isto se dá em cada indivíduo, o que cada um faz com isso, consciente ou inconscientemente, é que é particular"'(p.141).

Assim, em todos os pesquisados, observou:

O sentimento de culpa associado ao meio de contaminação e que, na teoria psicanalítica, é explicado pela repreensão que o próprio sujeito faz de seus atos. E são os atos que o adoeceram pelo HIV, daí o sentimento de culpa aflorar.

“A negação (...), conseqüente dos sentimentos de culpa e do abalo sofrido na superfície 
representacional, decorrentes do contágio pelo HIV (...)”; é um mecanismo utilizado que promove a condenação das próprias práticas sexuais, quando estas foram as fontes da infecção. Isto provoca um abalo na identidade, uma vez que essa é decorrente de uma realidade forjada por estas práticas. "A identidade, então, ameaçada, tem de defender-se e, dentre tantas outras possibilidades, também o faz encobrindo suas representações relacionadas à sexualidade, considerar, então, 'errada', desviante, perigosa, enfim, a grande culpada pela contaminação" (p.143). (destaque da autora).

Houve, em algum momento, fixação na representação de "aidético" (destaque da autora), com imobilidade e rigidez na identidade.

As representações associadas à aids foram negativas, pois ligadas a conflitos, culpa, sofrimento, castigo e morte; presentes em todo o período pesquisado pela autora.

A autora, por fim, cita NIETZSCHE: “... que o pensar sobre a doença não cause ainda mais sofrimento que a doença em si”, refletindo que isso ocorre quando não há possibilidade de elaboração dos sentimentos ligados à doença e suas representações e de outras formas de "ser" e "estar no mundo", ( destaque nosso) tarefa que a psicanálise se propõe a fazer.

Sugestões: decorrente do último parágrafo, a autora sugere a utilização dos recursos oferecidos pela psicanálise no sentido de ampliar as possibilidades representacionais das pessoas, para que uma doença (particularmente a aids) não seja tudo, mas apenas uma doença e que, o doente, seja uma pessoa com aids, não seja um "aidético" (destaque da autora).

\section{Indicação Bibliográfica:}

Pessoa Labaki ME. A situação do desamparo e aids. Pulsional - Revista de Psicanálise. 1999; 119: 17-27.

\section{FICHA TÉCNICA - TEXTO 50}

Autor: Renate Meyer Sanches

Instituição: Pontifícia Universidade Católica de São Paulo - Programa de Pós-graduação em Psicologia Clínica - Laboratório de Psicopatologia Fundamental

Local: São Paulo

Ano: 2000

Título: Da sobrevivência à existência: a ressignificação da vida diante da aids.

Tipo de Produção: Tese de Doutorado

Fonte:

Instituição envolvida: Não mencionada no texto.

Tema Principal:

a) Aids Social

b) Aids Mental

Sub-temas:

a) Enfrentamento do tabu da aids pelos psicanalistas através da busca de compreensão.

b) Ressignificação da vida 
c) Psicossomática

d) Síndrome do Pânico

Objeto do Texto: Compreensão da aids através do uso do conceito de Aids Mental, como “... um estado mental caracterizado pela fantasia de estar contaminado pelo vírus HIV" (p.1). Como pano de fundo estão os conceitos de falso self e verdadeiro self da teoria Winnicottiana.

Objetivo do texto: Privilegiar outro ângulo de análise da questão da aids que não seja o da destrutividade e da culpa, mas o da reorganização da vida (com mudanças externas e internas) e da busca de um sentido de maior plenitude e atividade do sujeito infectado (ou sentindo-se infectado). Discutir “... as estruturas e dinâmicas psíquicas em que esta procura [inconsciente do vírus HIV] pode significar, preponderantemente uma busca de vida e não de morte. (...) foram propostas mudanças técnicas na parte clínica com estes pacientes" (Resumo).

Linha teórica: Freudiana e Winnicottiana

Conclusões:

Após discutir exaustivamente o significado dos conceitos de:

- Aids Orgânica (“... conjunto de sintomas físicos derivados da ação do vírus HIV no organismo [...] abre caminho para um amplo espectro de infecções oportunistas”.) (p.240),

- Aids Social (conjunto de fantasmas culturalmente associados à AIDS) e

- Aids Mental (“... um estado mental caracterizado pela fantasia, baseada ou não na realidade, de se estar contaminado pelo vírus HIV”) (p.241) (“... situação traumática, vivida como uma catástrofe que provoca um caos interno, uma perda temporária na vivência da continuidade do ser e da identidade, decorrente do desmoronamento repentino das defesas diante da invasão do 'vírus' da Aids Social”.) (p.17),

a autora conclui que se encontra diante de um limiar entre o psíquico, o somático e psicossomático. Nesse lugar, os limites são pouco tangíveis. O indivíduo sente-se potencial ou concretamente doente. Se o meio responde de forma adequada, propiciando a vivência de uma mãe substitutiva, reconhecendo a origem da dor, tornando possível a vivência dos aspectos de self verdadeiro antes encapsulados, abre-se o caminho para uma possibilidade de integração e um espaço para a existência.

Utilizando as teorizações de WINNICOTT, a autora considera que, durante toda uma vida, sob o falso self se esconde o verdadeiro self ao qual estão ligados a pulsionalidade e a agressividade. A revelação [do HIV positivo] é uma ameaça tanto temida como desejada. Isto significa que, por um lado, o self verdadeiro é significado como algo desprezado e perigoso para o próprio indivíduo e para o outro (pelas significações vinculadas socialmente ao vírus HIV), mas por outro lado, pode existir esperança de que o intolerável possa ser acolhido e aceito. Inconscientemente, o indivíduo que se expõe ao vírus, ou que tem a fantasia da infecção, não somente faz um movimento autodestrutivo movido pela culpa, mas também pode estar à procura de uma função continente para aspectos de sua própria sexualidade e agressividade aprisionados até então. Tornar-se doente, no 
concreto ou na fantasia, pode ser uma forma de tentar se ver reconhecido, acolhido na dor e na verdade, modificando a experiência primitiva insatisfatória pela ação de um ambiente "suficientemente bom" (destaque da autora). Sua busca é por cuidado, mesmo tendo que pagar um preço alto do ponto de vista físico, social e psíquico.

Nesse processo, as saídas podem ser: a entrega, a fuga e a elaboração. Nem sempre um caminho exclui o outro.

a) Na entrega, a Aids Mental se sobressai “... o indivíduo passa a viver a morte em vida: as possibilidades de prazer, de criação, de vida são 'assassinadas' (...) e a expectativa de vida diminui significativamente" (251-2).

b) Na fuga, existe a possibilidade de uma reorganização do sistema defensivo de forma rígida. $\mathrm{O}$ indivíduo pode se considerar vítima e/ou herói, como ganho secundário da constatação do HIV. Vive assim, até que as defesas se desorganizem.

c) O caminho mais difícil é o da elaboração. Ele envolve a necessidade de se defrontar com os fantasmas, com tudo que se teme e se esconde. Isso pode ocorrer pelo uso da palavra que nomeia e dá significado à situação traumática, segundo DOLTO (1989), citada por SANCHES na p.252. Mas, voltando à concepção Winnicottiniana, seu referencial de análise, a autora conclui que a experiência de compartilhamento, não só da palavra, mas de tudo o que o contexto de um ambiente "suficientemente bom" proporciona, alcançará aspectos do verdadeiro self até então inacessíveis. A dor, assim dividida com os semelhantes, se tornará mais suportável, podendo haver, então, a abertura do caminho para a elaboração e para a vida. Os ganhos secundários são: o alívio pelo desvendamento da parte oculta, e o sentir-se vivo por ter enfrentado e sobrevivido à catástrofe. Passa a haver a possibilidade de sublimar e criar, ampliando as possibilidades de elaboração.

Isto só será possível com uma modificação do setting, permitindo a emergência de conteúdos de não-integração. As necessidades egóicas, assim satisfeitas ocasionarão o fortalecimento do ego.

A autora considera, finalmente, que a aids pode “... ser inconscientemente procurada:

- num movimento autopunitivo, impulsionado pela culpa (aspecto não desenvolvido nessa tese);

- para nomear o inominável (destrutividade, agressividade), assumi-lo como seu e ao mesmo tempo negá-lo;

- numa tentativa de romper estruturas falso self, em colapso. Aspectos clivados aparecem (explícita ou projetivamente) na procura de um ambiente 'suficientemente bom', continente" (253-4) (destaque da autora).

Dependendo da organização (ou não) do self verdadeiro, poderá haver um rompimento da estrutura falso self, permitindo que um novo ambiente "suficientemente bom" se constitua. Isto é fundamental, segundo a autora, para a passagem da sobrevivência à existência, ao SER.

Sugestões:

Esse ambiente "suficientemente bom" que tem chance de ser constituído pode ser referido não só aos familiares, parceiros e amigos do paciente, mas também aos cuidadores, médicos e outros 
profissionais de saúde, além dos grupos de auto-ajuda.

Indicação bibliográfica: Não foi encontrada referência de interesse para o presente estudo. 